Historic, Archive Document

Do not assume content reflects current scientific knowledge, policies, or practices. 

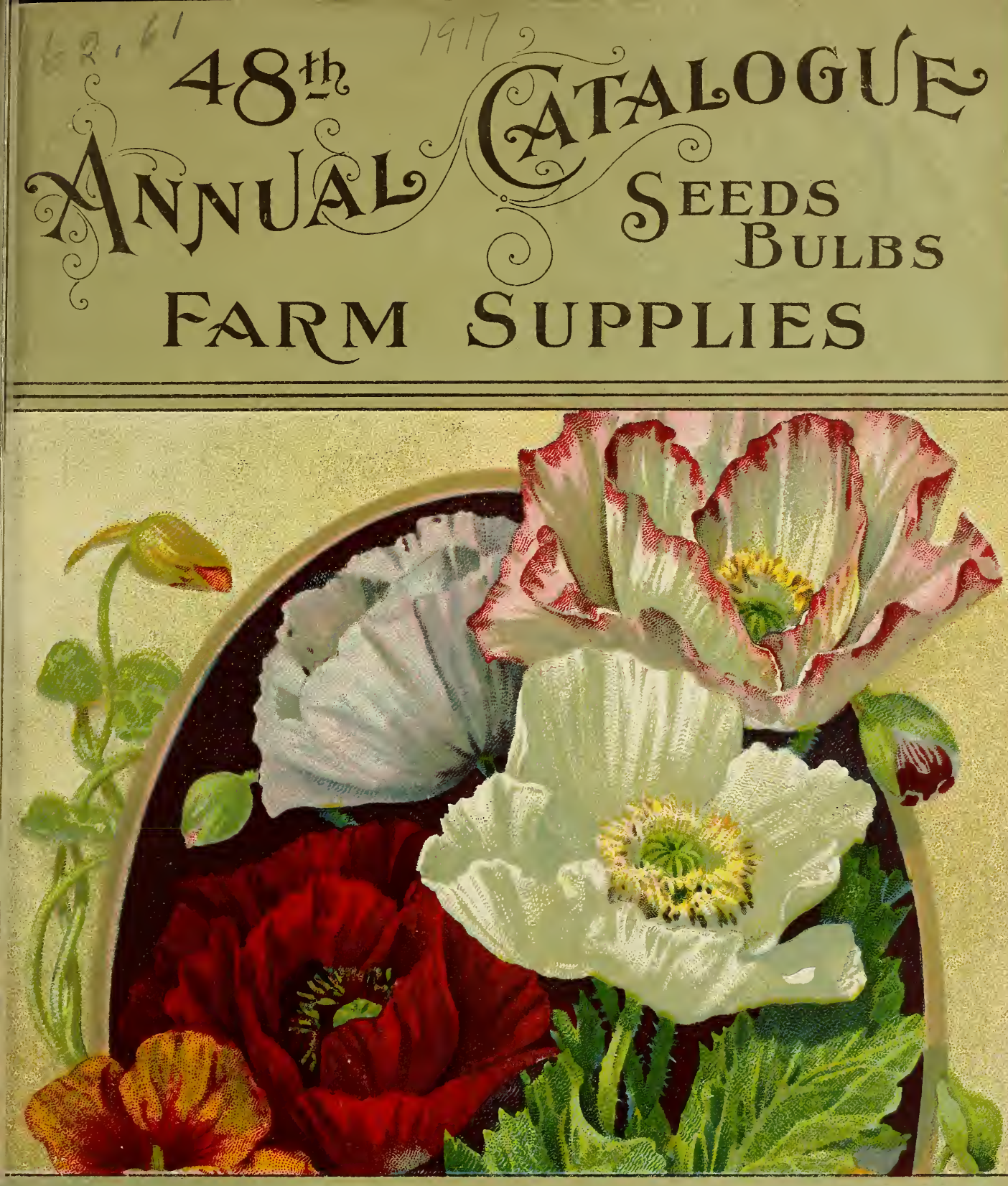

$$
\text { N H E B EING }
$$

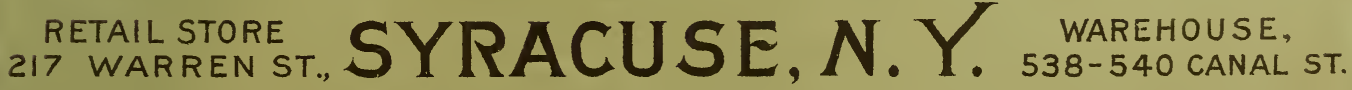




\section{A WORD OF APPRECIATION}

This makes the 48th year in which we have served Central New York people in helping them to make an annual success of their harvests.

The fact that the children and grandchildren of my first customers are now my regular patrons, proves that the house of Ebeling has not only won but has held the complete confidence of its customers.

For 48 years our policy has been to import, contract for and handle only the highest grade seeds, bulbs, and supplies for the farm, garden, greenhouse, lawn, dairy or poultry yard.

We wish to take advantage of this opportunity to thank you, the reader, fpr the kind words in our behalf that you have extended to your friends and neighbors. It is valued far more than the profits of the business to which it has contributed. As a result of your co-operation, the year just passed has proved most successful.

Assuring you that my heartiest hope is that this, my latest Catalog and Seed Book, will in turn more than do its share to make your 1917 the happiest and most prosperous of all years, I remain

January $1,1917$.

F. H. EBELING.

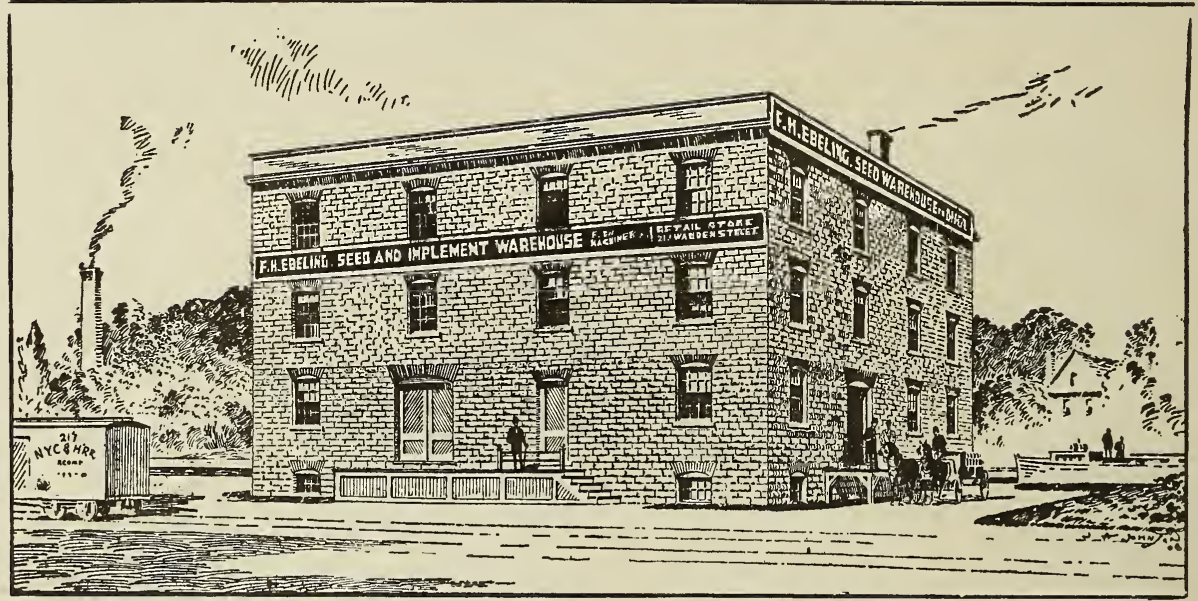

F. H. EBELING'S SEED AND IMPLEMENT WAREHOUSE, 538-540 CANAL STREET

RETAIL STORE, 217 WARREN STREET

USEFUL TABLES

Of Plants per Acre at the following distances apart. Number of Plants Produced from 1 oz. of Seed.

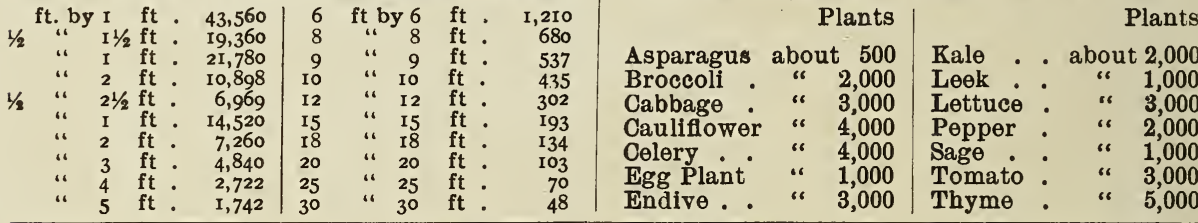

SEED SOWN PER ACRE

Seed Sown per Acre Weight per bu

Alfalfa, or Lucerne 20 to $30 \mathrm{lbs}$........... $60 \mathrm{lbs}$, Barley, $1 \frac{1}{2}$ to 2 bu. $48 \mathrm{lbs}$.

Beans, Field, $1 / 3$ to $1 / 2$ bu............... $60 \mathrm{lbs}$

Beans, Green Soy, $3 / 4$ bu......................... 60 lbs.

Beet, 4 to 6 lbs.

Blue Grass, 2 bu.

Bromus Inermis, 20 ibs

Buckwheat, 1 to $1 \frac{1}{2}$ bu. 48 to $50 \mathrm{lbs}$.

Cabbage, $1 / 4 \mathrm{lb}$. .................................. $20 \mathrm{lbs}$

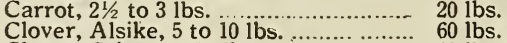

Clover, Crimson, 15 lbs.......................... 60 lbs.

Clover, Red, 10 to 15 lbs. 60 lbs.

Clover, Sweet, 25 lbs. Melilotus Aiba 60 lbs.

Clover, White, 10 to 12 lbs................... 60 lbs̀.

Corn, Ensilage, $1 / 4$ to $1 / 2$ bu................... $56 \mathrm{lbs}$

Corn, Fieid, $1 / 4$ bu.................................. 60 lbs

Corn, Sweet, $1 / 4$ bu.................................... 45 lbs

Cucumber, $1 \mathrm{lb}$. ............................. 25 to $30 \mathrm{lbs}$

Lawn Seed, $1 \mathrm{lb}$ to $250 \mathrm{sq} . \mathrm{ft} \ldots \ldots . .25$ to $30 \mathrm{lbs}$

Meadow Foxtail, 3 bu......................... $7 \mathrm{lbs}$

Meadow Grass, Rough Stalk, 35 lbs. - 18 lbs

Flax Seed, $1 / 2$ to $3 / 4$ bu. $56 \mathrm{lbs}$

Millet, $1 / 2$ to $3 / \frac{1}{4}$ bu.

Seed Sown per Acre

Weight per bu.

Millet, Hungarian, $1 / 2$ to $3 / 4$ bu. ......... $48 \mathrm{lbs}$.

Millet, Japanese, $1 / 2$ bu..................... 32 lbs.

Oats, 2 to 3 bu............................ 32 lbs.

Onion, 5 to 6 lbs....................................... 56 lbs.

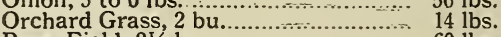

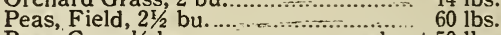

Peas, Cow, $1 / 2$ bu............................... 50 lbs.

Peas, Wrinkled, ............................about 50 :bs.

Potatoes, 6 to 8 bu. .............................. 60 lbs.

Pumpkin Seed, 4 ats.......................... 27 lbs.

Rape, Dwarf Essex, 4 to 6 lbs. .............. 50 lbs.

Red Top, Recleaned, 15 lbs. ................ 30 lbs.

Rye, 1 to 2 bu., Winter and Spring .... $56 \mathrm{lbs}$.

Sorghum, $1 \frac{1}{2}$ to 2 bu ................. $56 \mathrm{lbs}$.

Spinach, 8 to $10 \mathrm{lbs}$. Squash, $2 \frac{1}{2} \mathrm{lbs}$.

Sweet Vernal, 1 to $1 \frac{1}{2}$ bu. ................. $11 \mathrm{lbs}$,

Timothy, $1 / 4$ to $1 / 2$ bu. ......................... 45 lbs,

Turnip, $1 \mathrm{lb}$

Vetch. Hairy, drilled (plus 1 bu. smali grain) 25 lbs.

Vetch, Hairy, broadcast (plus 1 bu. small grain) $75 \mathrm{lbs}$

Vetch, Spring (plus 1 bu small grain) 25 lbs

25 lbs . Winter and Spring ...... 60 lbs.

$60 \mathrm{lbs}$.

$60 \mathrm{lbs}$.

$60 \mathrm{lbs}$.

NON-WARRANTY.-F. H. Ebeling gives no Warranty, express or implied, as to description, quality, productiveness, or any other matter of any seeds, bulbs or plants he sends out, and he will not be in any way responsible for the crop. If the purchaser does not accept the goods on these terms, they are at once to be returned. 


\section{EBELING'S EXTRA LAWN GRASS MIXTURE}

This mixture will insure a beautiful, compact, evergreen sod on any lawn where the essential requirements of grass culture have been complied with. Its component parts are the grasses peculiarly adapted to lawns and door yards, including choice selected strains of Kentucky Blue, etc., along with the best known creeping or sod forming sorts: We have included a little white clover in the mixture, regarding it as essential. Full provision is made for a succession of growth, so that there shall be no break in the richness of the verdure from spring until autumn, and experience proves that Ebeling's Extra Lawn Grass Mixture is now perfect. Nothing better can be purchased on the American market, no matter what claims may be advanced by other seedsmen. This is because we employ the choicest and heaviest strains of grass seed in making the mixture. As to preparation of the soil, we recommend a thorough working and manuring to a depth of 8 or 9 inches, and a regular semi-annual application of top dressing afterward. It is a good practice to use Sheep Fertilizer and Ground Bone in the spring and fall; also, to renovate the lawn every spring with a little fresh seed. Per tb., 25c; Special price for quantity.

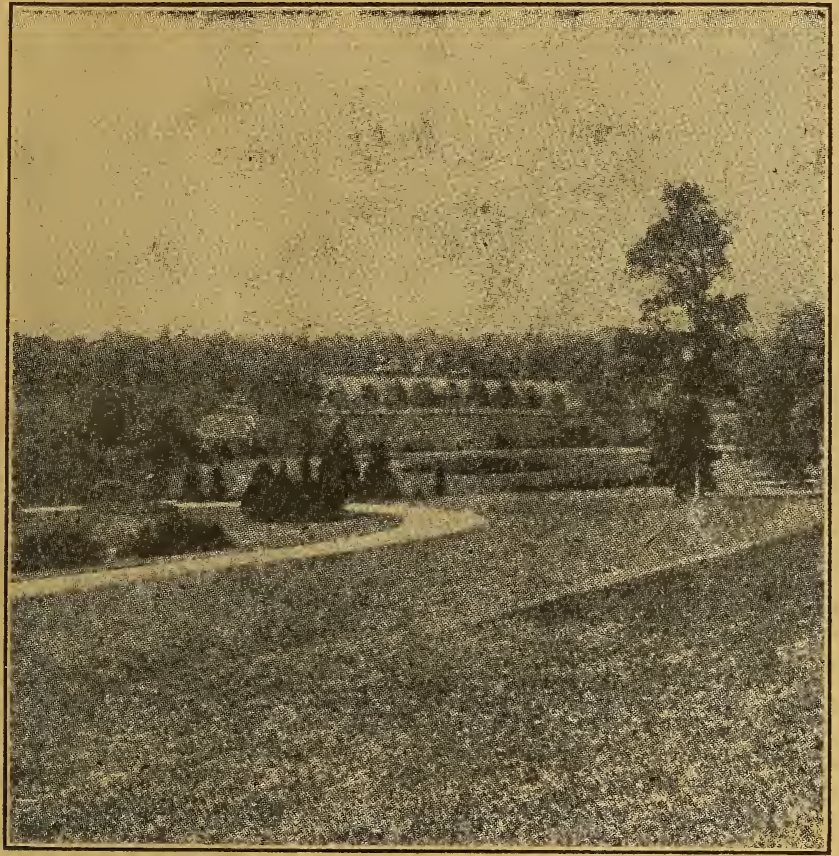

How to Make

a

\section{Lawn}

Have soil thoroughly spaded up, enriched with commercial fertilizer or well rotted manure, level and roll it well to make compact. Select a still, damp day for seeding; sow onehalf of the seed from north to south and half from east to west, rake it over and roll again. when grass comes up re-seed the bare spots. When grass is 2 inches high cut it, and as necessary thereafter. Don't rake up short clippings. as they make a good mulch. Always thoroughly soak a lawn when sprinkling, whenever required, but never sprinkle lightly.

QUANTITIES TO USE For 300 sq. ft.... 1 lb. For 1500 sq. ft... 5 ths. For 3000 sq. ft...10 tbs. For one acre....100 ths.

For renovating old lawns about half the above is sufficient.

GROUND BONE. Excellent for grass plots, gardens, etc. 5 tos. $25 \mathrm{c} ; 25$ tbs, $75 \mathrm{c} ; 50$ tbs. $\$ 1.25 ; 100$ tbs. $\$ 2.25$.

SHEEP MANURE, PULVERIZED. (Wizard Brand.) A pure natural manure, unequaled for mixing with potting soil, for lawns, general vegetable and flower garden fertilizer. 5 tbs. $25 \mathrm{c}$; 10 tbs. $40 \mathrm{c}$; 25 tbs. $75 \mathrm{c} ; 50$ tbs. $\$ 1.25 ; 100$ tbs. $\$ 2.50$.

HARDWOOD ASHES. Indispensable as a lawn dressing, or to apply to orchards. Should be applied late in fall or early spring. 5 tbs. $20 \mathrm{c}$; 10 tbs. $35 \mathrm{c} ; 25$ tbs. $60 \mathrm{c}$; 100 tos., $\$ 2.00$.

LAND PLASTER. Much used in composting or mixed with guano, etc. 100 tos. $\$ 1.00$.

LIME (Hydrated). For lawn and field use where the ground has become sour. $40 \mathrm{tbs}$. $75 \mathrm{c} ; 100$ tbs. $\$ 1.50$.

BOWKER'S PLANT FOOD FOR HOUSE PLANTS. (Odorless.) The best Plant Food on the market. May be used either dry or liquid. Especially fine for ferns. Price, $15 \mathrm{c}$ per pkg.

BLOOD. (Dried.) One of the quickest acting fertilizers, being immediately soluble. $5 \mathrm{tbs}$. $30 \mathrm{c} ; 25$ ths. $\$ 1.50 ; 100$ tbs. $\$ 4.50$.
SALT, AGRICULTURAL. For topdressing asparagus beds. Apply very early in spring at the rate of 800 to 1000 pounds per acre. 200 tbs., \$1.50; per ton, $\$ 12.00$.

CLAY'S FERTILIZER, This valuable imported manure is especially recommended to all who grow either fruit, flowers or vegetables and wish to bring them to the highest perfection. $1 \mathrm{to} .10 \mathrm{c}$; $100 \mathrm{tbs}, \$ 9.00$.

SCOTCH SOOT. (Genuine Imported.) Gardeners know the value of the genuine article for stimulating a healthy growth of dark green foliage, and its beneficial effect in freeing the soil from slugs, grubs and cut worms. 28 tbs. $\$ 1.50 ; 56$ tbs. $\$ 2.50 ; 112$ tbs. $\$ 5.00$.

TOBACCO STEMS. An indispensable lawn covering for winter. It not only acts as a protector, but imparts large quantities of ammonia and drives away insects and moles. Bale, $\$ 1.00$ to $\$ 2.00$.

NITRATE OF SODA. A fertilizer for all crops. It is very quick in action and hastens maturity of crops fully two weeks. Being quickly soluble, it should not be applied until the plants are above ground. 5 fos. $30 \mathrm{c}$; 25 tbs. $\$ 1.25$; 100 tbs. $\$ 4.75$. Large quantities, prices on application. 


\section{SEED CORN SITUATION CRITICAL}

A cold, wet season has retarded the growth of corn. This year's crop in many parts of the corn belt is immature, contains an excessive amount of water, and is unfit for seed. Scarcity of seed corn is the most serious in many years. There will be a short crop in 1917 , and millions of dollars lost to the farmers, unless great care is taken in selecting the best matured corn for seed and storing it where it will not freeze.

\section{EBELING'S HIGH GRADE SEED CORN}

Compton Early A small eared, small kernelled yellow flint. Popular trymen, dove and pigeon growers like it for feeding purposes. Price, $\$ 2.50$ per bushel.

Early Yellow Flint This is the largest, handsomest Early Golden Yellow Eight Row Flint Corn we have ever size, and of a most beautiful golden yellow. We will offer a limited quantity at $\$ 2.50$ per bushel.

Angel of Midnight A most popular extra early 8-row yellow flint for one so early. If yar corn. Ears of medium size, a splendid yielder "Angel of Midnight," the farmer's friend. Stalks of medium size. Price, $\$ 2.50$ per bushel.

Longfellow This is very well named, being the longest eared 8-rowed vellow flint corn known. It is strikingly handsome, medium late and should be planted on rich soils. It is the most prolific of all the flint sorts. Very popular among corn raisers. Stalks are of good size. Price, $\$ 2.50$ per bushel.

Canada Smut Nose This good old standard sort is one that has ever. It is as popular as the tip of the ear. Price, $\$ 2.50$ per bushel.

Sanford White Flint A splendid large long-eared 8-rowed sort with big white kernels, small cob, easy to husk and a great basket filler. One of the biggest yielding sorts known. Ripens rather late, likes rich soils, early planting, old-fashioned cultivating and hoeing, with the result that you have a growth like a young forest, and a yield fit for a king. Very popular in Northern New York. Price, $\$ 2.50$ per bushel. Golden Nugget A splendid new variety. The largest and most proof variety of flint corn. Over ninety bushels of shelled corn has been grown to the acre. Will mature in a normal season in New. York State. Price, $\$ 3.00$ per bushel.

White Cap Yellow Dent This is an early yellow Dent, similar to capped kernel which makes it look like a white corn. The grain with this exception is a beautiful yellow. A splendid planting corn. Its earliness permits it to ripen in New York State. Price, \$2.50 per bushel.

Early Huron Dent One of the best of the Dent varieties; ripening State with good results. Color, beautiful golden yellow, ears of medium size and an excellent kind to use where flint corn results are looked for Prlce, Yellow $\$ 2.50$ per bushel.

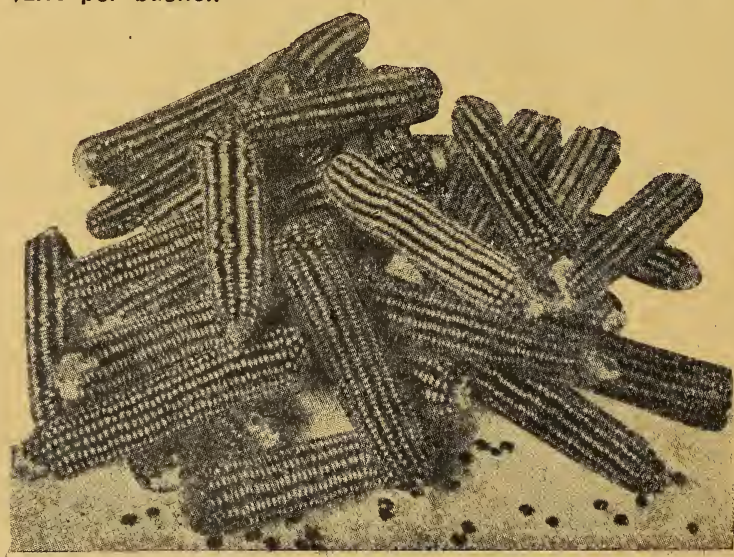

Bloody Butcher It's the orn-as early as the ar liest the North or the Flint The stock like it and varieties. will go as far as $11 / 8$ bushels of either white or yellow varieties. Worms and birąs do not bother Bloody Butcher very much and for that reason it is much sought after by the southern planter. Color deep cherry red with white cap, generally 14 rows on a small cob. Stalks medium height, fairly heavy. Price, $\$ 2.50$ per bushel.

\section{Early Eureka, or} Champion White Pearl Early, thoroughbred White Dent. Ears average sixteen rows, with very small cob: ripens in 90 to 100 days from time of planting. Very productive, yielding fully as well as the Yellow Dent sorts. Price, $\$ 2.50$ "Bloody Butcher." per bushel. 


\section{EBELING'S HIGH GRADE SEED CORN-Continued} Silver King or Wisconsin No. 7 A Dent variety. Ears average 8 to 10 inches, in size and type. It pure white in color with good length kernels. A strong grower and early enough to mature as far north as St. Yaul, and especially adapted to resist cool weather. Price, $\$ 2.50$ per bushel.

Golden Yellow Pop Corn eating qualities. We offer a limited quantity at $15 \mathrm{c}$ per to.

This extra sweet yellow pop corn is becoming very popular on account of its sweetness and tender White Rice The most popular for home use. The grain is pointed, pops white, and full. nearly one inch. Price, 10c per tb.

\section{EBELING'S HIGH GRADE ROOTS FOR STOCK FEEDING}

Mangel Wurzels For stock feeding. We should learn a lesson from our brother extensively for stock feeding, which produce the greatest results for the labor and money invested.

Ideal Sugar Mangel Beet See page 19 for the shape of this wonderful Mangel. dis a perfect chunk of a beet being as large at the bottom as at the top. Stands two-thirds above ground. Is easily harvested even on hard soils. This new and original Mangel has been tested alongside thirty other Mangels and by strict laboratory tests on trial grounds and field demonstrations, has proven to be IDEAL and superior in quality. Per tb., $\$ 1.25$.

Mammoth Long Red This is a heavy cropper and a large yielder. The roots grow from one-half to two-thirds above the surface, and are length by six inches usual diameter. Dark, richly colored foliage, skin dark red, flesh white with veined rings of rose pink. Oz. 10c;1/4 $\mathrm{tb} .20 \mathrm{c} ; \mathrm{tb} .45 \mathrm{c}$. For further particulars see page 19.

Detroit Dark Red We believe this is the best beet for the market and home garden, and on account of its uniformly deep rich color the most desirable for canning. Tops small, upright in growth. Very smooth and of dark blood red color. Flesh is deep vermilion red, zoned with a lighter shade of the same color. The Detroit Dark Red Beet is used extensively by dairymen during milk testing periods. to. \$1.25. Long Orange Carrot The most popular of the older Carrots for farm use on melselection of the best formed and deepest colored roots. One of the best of the sweet carrots for stock feeding, and a large yielder. Per tb. \$1.25.

White Belgian Carrot Grows one-third out of the ground. Root white, green roots are of large size and the variety is extensively grown for stock feeding. Per to., $\$ 1.00$.

\section{CANADA FIELD PEA}

Is one of the very best soiling crops of the North. It is sometimes grown alone, but the most satisfactory dairy results'come from sowing it with oats, rye or barley. It makes good ensilage, and is an admirable food either green or dry for cattle, being highly nutritious and rich in milk-producing elements. It is quite hardy and may be sown early in the spring, and will be ready to cut in May or June. The seed should be sown at the rate of 1 to $11 / 2$ bushels per acre. Per bu., $\$ 4.50$.

\section{BUCKWHEAT}

Market price changes. Write for quantity prices.

Buckwheat is mostly. used for filling in fields remaining unplanted after the middle of sune. It is well to bear in mind that on worn-out soils a plowed under buckwheat field is a great soil fertilizer and improver. Sow 1 bushel per acre.

Japanese A popular and standard sort. Very large grains of dark brown color. Early Silver Hull A very prolific and early sort. Grain a light gray in color. A great favorite Bushel (48 tbs.), $\$ 2.00$.

\section{SPRING RYE}

Used with profit as a catch crop where grain has winter killed. Quite commonly employed within recent years. Sow $11 / 2$ to 2 bushels to the acre.

\section{MARQUIS SPRING WHEAT} A wonderful new variety which has become very popular and met with widespread inter-
est. It is remarkably early and exceedingly productive. Per bu., $\$ 3.00$.

\section{SUDAN · GRASS}

Sudan is a tall, annual grass, reaching a height from 7 to 9 feet when planted in rows and allowed to mature for a seed crop; broadcasted and cut "in the bloom" for hay, about 4 feet. It dies each year like sorghum and millet and must be seeded each spring, so can never become a pest. It stools very freely, throwing out many stems from one crown. It is easily cured and handled as a hay crop. Sudan Grass is easily injured by frost, and therefore should not be planted until all danger of frost is past. It will produce under widely varying conditions at each cutting fully as $\mathrm{much}$ as millet and yield from two to four cuttings per year. Price per th., 50c. 


\section{TESTIMONIALS}

Frank Bradford, Skaneateles, N. Y., R. F. D. 3, says this regarding our Alfalfa:

"Your seeds purchased this season were ail as represented, and the Alfalfa was the finest I have ever seen. I sowed it with a bushel and a half of Oats to the acre, and when I cut the Oats the Alfalfa was as tall as the Oats, and now has a good start again."

Mr. F. H. Ebeling, Syracuse, N. Y.

Clinton, N. Y., R. F. D.

Dear Sir-I wish to say that the crops received from the seed purchased from you have been better than I anticipated owing to the wet spring we had in this section. We received an extraordinary large crop of ears on all corn, especially of the "Gold Mine" corn.

WILLIAM BURGESS.

F. H. Ebeling, Syracuse, N. Y.

So. Otselic, N. Y., May 1, 1916.

Dear Sir-We have received your seed all right and are very much pleased with it.

G. C. WEAVER \& SON.

F. H. Ebeling, Syracuse, N. Y.

Dear Sir-I enclose check for seed corn bought of you, and glad, N. Y., Oct. 2, 1916. corn in our section this year.

F. H. Ebeling, Syracuse, N. Y.

Cazenovia, N. Y., Oct. 13, 1916.

Dear Sir-The seed we received from you was certainly fine. We have a fine catch and no foul seed in it, and am very much pleased with them.

HENRY STOKER.

F. H. Ebeling, Syracuse, N. Y. seeds and hope to do business with you in the future.

F. H. Ebeling, Syracuse, N. Y.

Morley, N. Y., Oct. 9, 1916.

Dear Sir-In reply to your letter I wish to say we have used your seed corn for two years, and both have been an extra successful crop. Last year our corn was a sight heavily eared and of heavy growth, but not woody or coarse. This year in spite of the bad year, it was well eared and said by people who had traveled over this section to be the best in St. Lawrence county. We recommend it to all farmers as a horse feed or for Silage. Respectfully yours,

NORTHRUP BROS.

Frank Matty, Syracuse, N. Y., R. F. D. 1, who used one of our Standard Emerson 5-ft. Mowers last season, was very much pleased with its work. He says it cuts perfectly wet, heavy grass. Knives begin cutting the moment the horses start. Runs easy with less draft, less oiling, and no sore necks for horses. Under perfect control and would not be without it. Says this is the first machine ever used that does such splendid and perfect work.

William H. Gifford, farmer, Syracuse, N. Y., says that the Emerson mower works fine, takes less oil, does better work, handled easier and is well balanced, don't make sore necks for horses, easier draft, and a whole lot more might be said in its favor.

F. H. Ebeling, Syracuse, N. Y.

Dear Sir-The Gould Monarch Sprayer, Fig. 1610, with $12-\mathrm{ft}$. bamboo extension, has given perfect satisfaction, giving a fine well distributed spray, even and close to a fog in fineness. Some of the trees are late in blossoming, and they will get another shower.
Yours very truly,
F. M. POWERS, Solvay, N. Y.

Mr. F. H. Ebeling, Syracuse, N. Y.

Seneca Falls, N. Y., Dec. 18, 1916.

Dear Sir-Having purchased seeds from you since 1879 , I feel very confident in saying that your seeds are among the best that grow. For several years I have used your Iowa Gold Mine Ensilage Corn, and have had such good results that the past year I sold many bushels to my neighbors. The Alberta Cluster Oats yielded 65 bushels per acre. From four bushels of your Telephone Peas I picked 135 bushels marketable peas. I also have 50 acres of the best new seeding that I ever had, from your clover and timothy seed. Yours very truly, HENRY G. DAY, Farmer and Market Gardener.

\section{Names of a Few Gardeners Who Have Dealt with This House Continuously from 32 to 47 Years.}

Wm. Clark, Solvay...............45 yrs. Charles B. Day, Skaneateles.............. J. N. Rose, Syracuse................ S. B. Babcock, Fulton.................... Albert Wright, Syracuse................. Michael O'Brien, Syracuse, died 1913.39 yrs. William Lambert, Salina.............. 38 yrs. Henry O'Neil........................ 32 yrs.

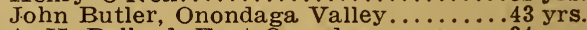
A. H. Ballard, East Onondaga............. y y y. Geo. Craddock, Onondaga, died $1912 \ldots . .43$ yrs. Henry Wright, Syracuse, died $1912 \ldots . .43$ yrs. Henry G. Day, Seneca Falls............. 37 yrs. Also hundreds of others who have dealt with us 8 to 30 years. 


\section{ALBERTA Cluster Oats THE FAMOUS, HEAVY YIELDING, HARDY VARIETY FROM THE GREAT NORTHWEST}

These oats were grown and shipped to us direct in car lots of about 2000 bushels, from that wonderful Alberta country of the Canadian Northwest. The soil is a deep, heary, rich loam, free from foul woeds, and which produces the very best of all grain crops. These oats have captivated the modern grain-growing farmer in every part of the eountry because they have proved themselves a big success. It's well known that oed oats grown in the Alberta country are unequaled in hardiness, height, yield, visor, in freedom from rust and from foul seeds. Canadian growers are extremely careful in seed selection and the Canadian government, through its rigorous seod laws, has greatly benefited our American farmers. It is safe to say that a more preftable variety of oats was never offered before in Central New York.

The two main handicaps in the growing of oats are foul weeds and the sowing of degenerated oats. Both problems are solved by our Alberta Cluster Oats. The virgin soils of the Canadian northwest are as yet free from the many foul weeds that affect our farmers, and these oats constitute a remedy for the farmers who have had trouble with their annual yield because they have continued to sow run-out and run-down sorts year after year. Alberta Cluster Oats compare with the majority of seed oats in the same way that a blooded Holstein compares with a common, scrub animal.

\section{KERNELS MUCH FATTER-WEIGH 45 POUNDS TO \\ BUSHEL}

These oats yield from 75 to 100 bushels to the acre. They have big, strong, stiff straws that stand up well on any ground. Their spangled heads are 12 inches long and ripen early.

Because of the unusually bad season of 1916 it was an "off year" for oats, but we have had splendid results from our Alberta Cluster Oats, which have produced rully two or three times more than the common oats.

Here's an opportunity for you to sell to your neighbors at a good price these remarkable oats for next season. We suggest that you order early.

Price $\$ 2.25$ per bushel; in 10 bushel lots, $\$ 2.00$ per bushel; 25 bushels (or more), $\$ 1.75$ per bushel.

Mr. F. H. Ebeling.

Erieville, N. Y., Dec. 13, 1915.

Dear Sir:-Would say I liked the Alberta Cluster Oats I purchased of you last spring very much. I sowed 7 acres, 3 bushels per acre by weight, from which we threshed 392 bushels, which is 56 bushel per acre. The otker kinds of oats near me yielded from 30 to 10 bushel per acre, and are not near as heavy.

I sowed Alberta oats with winter vetch.

$$
\text { Yours truly, }
$$

I. J. WALRAD. Seneca Falls, N. Y.

Mr. F. H. Ebeling, Syracuse, N. Y.

Dear Sir:-Will say in regard to the "Alberta Cluster Oats" that I am very much pleased with them as they yielded beyond my expectation. I had 26 acres and had 1560 bushels, and weighed 40 pounds per bushel. The weather was bad to gather them and was obliged to cut them with the mowing machine and rake with a horse rake, and we surely left 10 bushels per acre on the ground. Very truly yours,

W. D. HILL.

Geo. A. Courbat, Mallory, N. Y., sowed 30 bushels of our Wonderful Alberta Cluster Oats and grew one thousand bushels. This was a record-breaking oat crop for Qswego County, and which has never before been equaled.

You are welcome to write Mr. Courbat, who will gladly verify the above.

TO PREVENT SMUT IN OATS. Formula-1 pt. of formalin to 20 gal. of water, wet $20 \mathrm{bu}$. (or in that proportion) of oats with this solution, mix thoroughly by shoveling, then pile in a mound, cover up well with blankets, etc., for 12 hours. This forms a gas that will destroy the Smut germ. After 12 hours spread out the Oats to dry. They will then be ready for sowing.

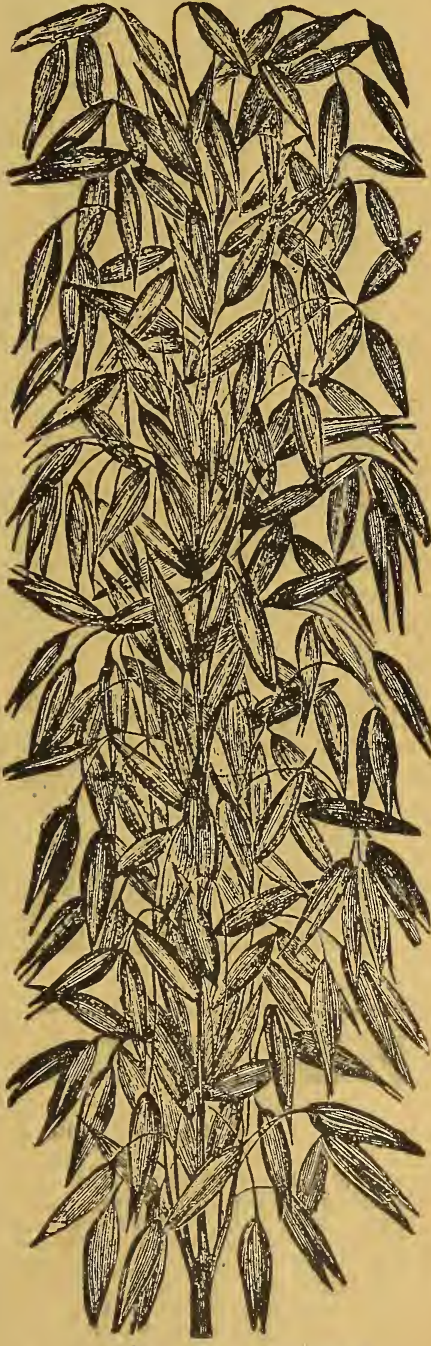

Alberta Cluster Oats 


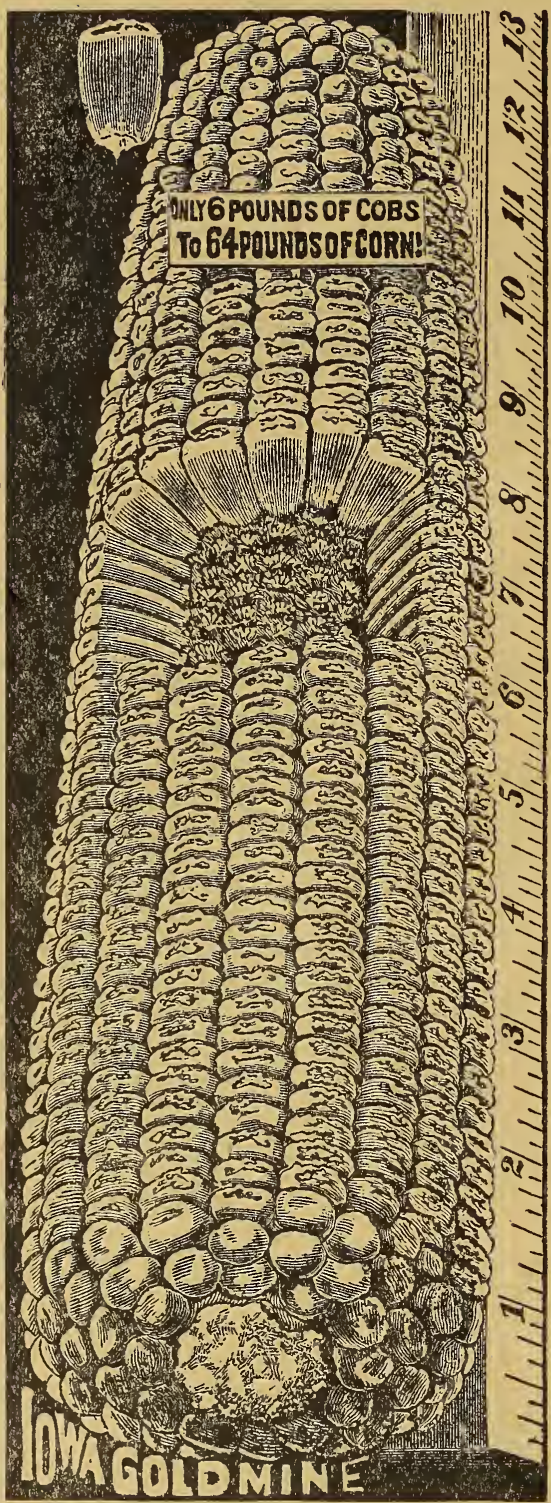

PRIDE OF THE NORTH

\section{Day Yellow}

We believe Pride of the North will mature farther north than any other Dent corn. Strong, hardy, vigorous grower, can be planted thickly and still make good-sized ears. For husking crop it ripens early, dries out quickly, and is an all around very satisfactory kind. Pride of the North has a bright red cob, ears medium size, with deep kernel. Many of the stalks have two good ears. Price per bushel, $\$ 2.25$.

\section{IOWA GOLD MINE ENSILAGE CORN.}

The Deepest Grained, Purest Yellow Corn Ever Grown. Every Year This Corm Puts Thousands of Good Gold Dollars in the Pockets of Our Customers.

Every year you have read in our catalog the extraordinary things we have had to say about our Iowa Gold Mine Corn. Every year our confidence in it has increased, and our only wish is that we knew how to make a. stronger plea for this, the king in the corn family.

We honestly believe it is the biggest market producer and money maker on the Amer. ican continent.

This real wonderful variety of corn grows 14 feet high and it matures with your feld varieties. Of all ensilage corn known to modern seedmen this has the largest kernel and smallest cob. You will find the grain value to be almost double of the Leaming or Pride of the North because of their immense cobs and small kernels. Iowa Gold Mine Ensilage Corn possesses every desirable feature of the Leaming and Pride of the North and in addition the great grain producing quality. we have told you about.

We earnestly advise you, the reader, to sow this corn this year and we know that you will be as enthusiastic as we are about this world-winning corn. Price $\$ 2.25 \mathrm{Bu}$. Shelled.

\section{LUCE'S FAVORITE DENT FIELD GORN}

Luce's Favorite, Minnesota King, Early Triumph, Poor Man's Dent. These four varieties are all one and the same thing.

This variety combines the best in the Western Yellow Dent and Eastern (White) Flint of which it is a hybrid. It combines all the good points in the family stock in that its stalks are tall, slender with many wids leaves. The ear has a long small cob filled with large broad dented kernels flattened out to the size of your finger nail. You can plant it as late as May 25 th and it will ripen with ordinary seed Flint sorts.

You will find Lucie's Favorite to be a strong growing bright yellow dented corn, which breaks off very easy in husking. It's the heaviest yielder you ever saw, the stalks often have two or three ears. It's extra good for fodder as the leaves are very broad and long. Like all hybrid of this class there are from eight to twelve rows to the ear. We have seen a bushel shelled that weighed $34 \mathrm{z}$ pounds and equal to 69 pounds of shelled corn to 2 bushels of ears. Price $\$ 2.50$ bushel.

\section{IMPROVED LEAMING}

This variety was originated by a $\mathrm{Mr}$. Leaming of Ohio and at once became a very popular and well known variety. It is probably more largely used in the East than any other variety for ensilage or fodder purposes. Stalks grow to good size, nine to twelve feet, and produce ears nine to eleven inches long, containing from sixteen to twenty-one row of dark golden yellow grains. It is a late variety and will not mature in the northern. states, unless the season is very favorable, but it is early enough to make it very valuable for an ensilage corn. Price per bu., $\$ 2.25$. 


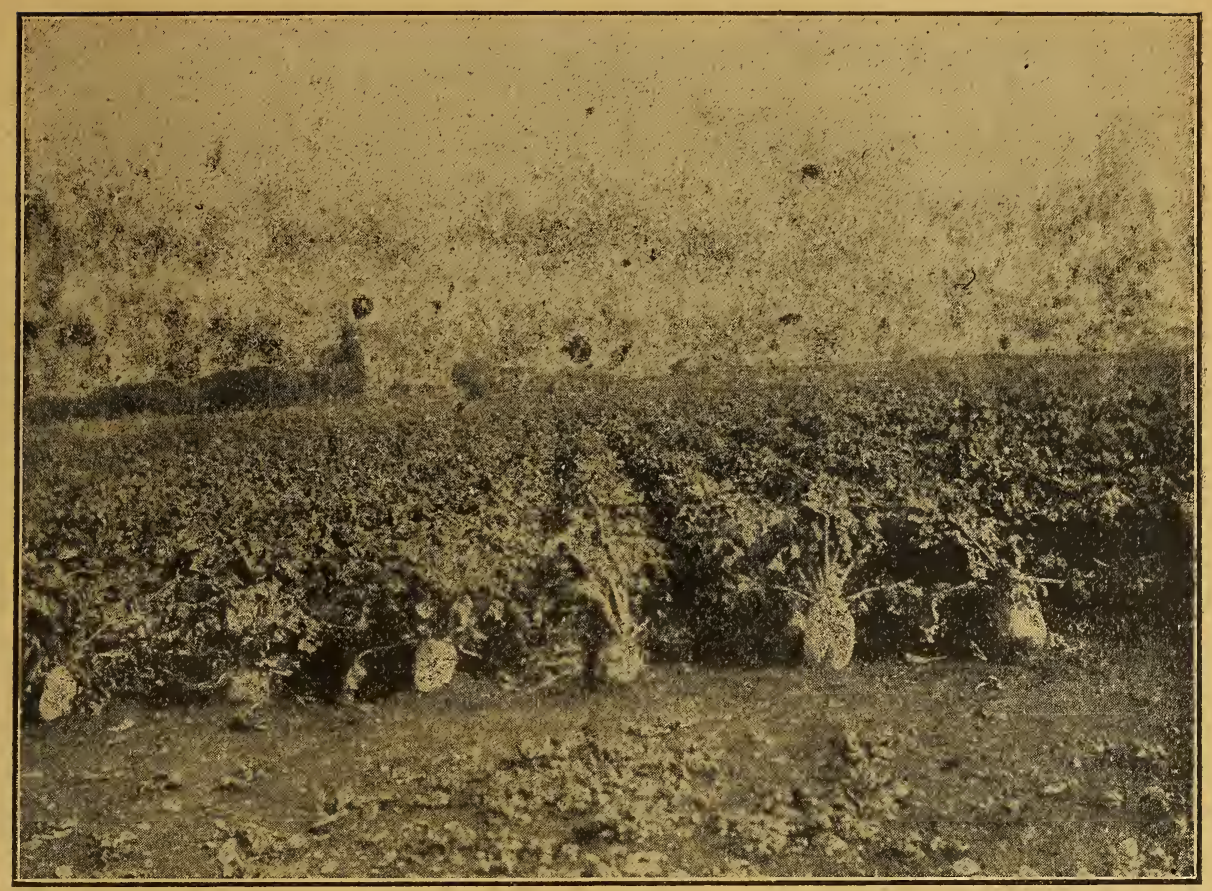

The above illustration was made from an actual photograph of a field of IDEAL SUGAR MANGEL BEETS grown on the Willowdale Farm, owned by Charles B. Day,

\section{IDEAL SUGAR MANGEL}

Our illustration shown above faithfully indicates the shape and style of this Beet. It is a perfect Chunk or Boot-leg type of a beet, which makes harvesting easy, especially in hard soils, as it grows fully two-thirds above the ground. This new and original Mangel Seed is imported from Europe, and can be secured only from one grower who has brought it to its present perfection. In trial ground and laboratory test of over thirty varieties, the IDEAL SUGAR MANGEL has proven superior in-each of the following points:

-It contains the greatest amount of dry sub- - Under favorable conditions they sometimes stance.

-It contains the greatest amount of sugar, which means feeding value.

- This Mangel grows high above ground.

-It's easiest of all to harvest these Mangels.

weigh thirty pounds.

- Size, quality and yield are three important factors that no farmer can afford to overlook.

-Price, \$1.25 per pound.

\section{DELICIOUS GOLD LINED ROCKY FORD}

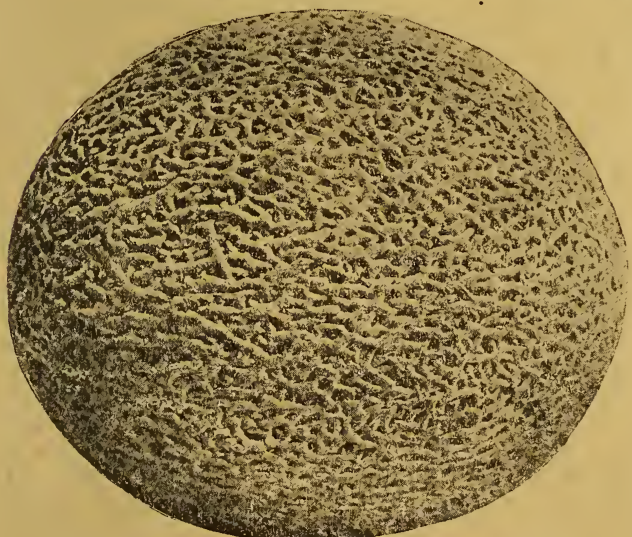

This melon has proven all we claimed for it. Its popularity has increased and our sales have far exceeded our expectations. We have carefully inspected every strain and type of Rocky Ford Cantaloupe, and we believe this to be the very best type, for all purposes, that there is in existence. It is an ideal crate melon, fruits all being uniform throughout the fields, and loss from undersize and oversize is very small, and its quality can not be excelled. Medium size, solid net, gold lined next to a small seed cavity, excellent quality, vines hardy, thrifty and rust resistant. Sealed bag stock is made up of the highest class of selected fruits. General stock sells for less money than sealed bag stock. $15 \mathrm{c}$ oz., $\$ 1.50 \mathrm{lb}$.

\section{SOLID NET BURRELL'S GEM}

This melon was offered by us for the first time last season. It is certainly a dandy! and we believe will supresede all ordinary stocks of this popular melon. Its shape is better and its solid net gives it a more handsome appearance than the old stole Burrell's Gem. 


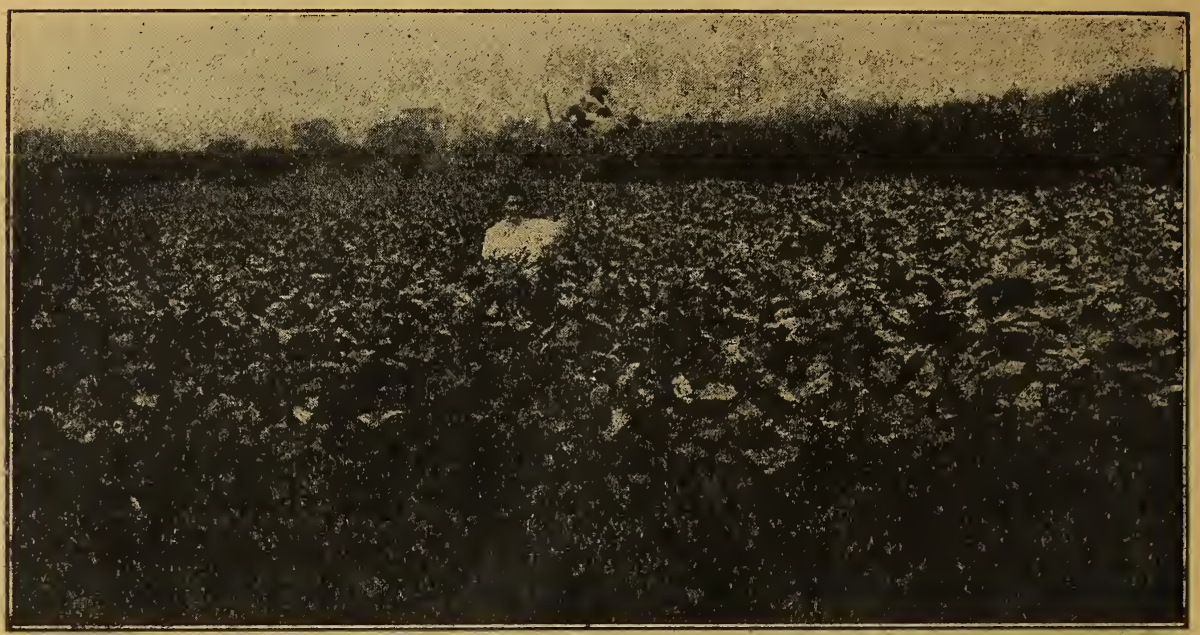

A Field of Early Medium Green Soy Beans, planted June 1st, and grown on the farm of Mr. S. F. Siefker, Manlius, N. Y.

\section{Mr. F. H. Ebeling:}

Manlius, N. Y., December 16, 1915.

Dear Sir-After a five-year trial with the early Green Soy bean, I am surely convinced of its great value as a soil improver. On soil that has been cropped with beans before, we find great masses of nodules on the roots of the beans, some as large as the ripe bean itself. This is a wonderful nitrogen extracting plant, returning humus and nitrogen to the soil in large quantities. We like to plant Soy beans in rows 28 inches, drilling about one bushel to the acre, about June 1st to 15 th, and cultivate the same as for corn. This will insure generally a good seed crop. For soiling purposes on clean ground, two bushels drilled same as for grain will yield large growth of green feed for september.

\section{Mr. F. H. Ebeling, Syracuse, N. Y.} Very truly yours,

\section{H. W. SIEFKER.}

Dear Sir-The Early. Medium Green Soy Beans have proven to be all that I expected and even more. I planted a large field in drills and cultivated them the same as corn. These produced a fine crop, which were harvested and stacked up the same as Beans. I shall use the straw for feeding, which we consider as valuable as hay.

A large quantity of the Early Medium Green Soy Beans was planted with my Ensllage Corn and harvested with it and put in the silo. I consider Soy Beans a valuable addition to silage as it produces a higher grade than can be produced in any other way.

I would recommend them to all dairymen for their money value in increasing the flow of milk and keeping stock in fine, healthy condition. Yours very truly, CHAS. M. CROUSE. Mr. F. H. Ebeling: SHELTER VALLEY FARMS, R. M. Stone \& Son, Proprietors.

Dear. Sir - I wish to say that the Soy Beans bought of you to plant with our Eureka Ensilage Corn for Silage purposes, were entirely satisfactory. They not only grew large, but furnished a lot of splendid forage and more than fulfilled our best expectations by the manner in which the seed matured. We feel that the EARLY MEDIUM GREEN SOY BEANS with the EUREKA and STATE CORN mixed and grown together has proven a very fine combination of feed for silage purposes. Soy Beans are also readily eaten by cattle in the green state.

USEFULNESS OF THE EARLY MEDIUM GREEN'SOY BEANS.--Soy Beans have a higher protein content than oil meal. Hay from them has a higher protein content than Alfalfa. The green fodder contains a higher protein content than either alsike or medium red clover. Add to this the fact that it is easily possible to secure two or three, or occasionally four to five tons of dry hay per acre; that from twenty to thirty bushels of seed per acre are frequently reported; that the plant is a legume and adds fertility to the soll fully as rapidly as the clovers or other legumes; that it will grow on soil too poor or acld for the easy success of Alfalfa; and you have a splendid combination, certainly qualities that are hard to excel with any of our cultivated crops.

No plant has a more useful range of possibilities than the Soy Bean. When one stops to think of the great feeding value of the grain, of the entire plant's being very valuable for forage, of $1 \mathrm{ts}$ being a legume and a heavy gatherer of nitrogen to the soil, not difficult to grow or exacting as to the kind of soil it requires, we must realize that it occuples a position unique among all our crops. Not only is the grain as nourishing as oil meal, but it is as greedily eaten as corn and as easily digested as any grain. Moreover, there seems to be a tonic effect about the entire plant, and stock fed either the grain or the forage become full of energy as with no other grain.

Time of Planting and Cultivation-Plow your land early in the spring. Prepare and oultivate the same as for corn, giving frequent harrowings to kill the weeds. Wait until corn planting time before planting the beans. Plant in with the corn or in alternating rows. Sow $3 / 4$ bu. to the acre. We advise planting in drills about 36 inches apart, 2 or 3 inches in the drill. Price $\$ 5.50$ per bushel.

Book on Soy Beans by W. F. Ingalls, a practical farmer, of Hamilton, $\mathbf{N}$. $\mathbf{Y}$., who has grown the Early Medium Green Soy Beans for many years, and is an authority on same Price, 60 cents.

We offer a book on "Green Soy Beans," written by Mr. W. F. Ingalls, who was pioneor in the introduction of these Green Soy Beans. This is a practical and truthful description, and will enable any farmer to produce the same results that Mr. Ingalls did. Price 50 cents, bound in book form. We earnestly recommend this book to progressive farmers, and vil mail book upon receipt of above price. 


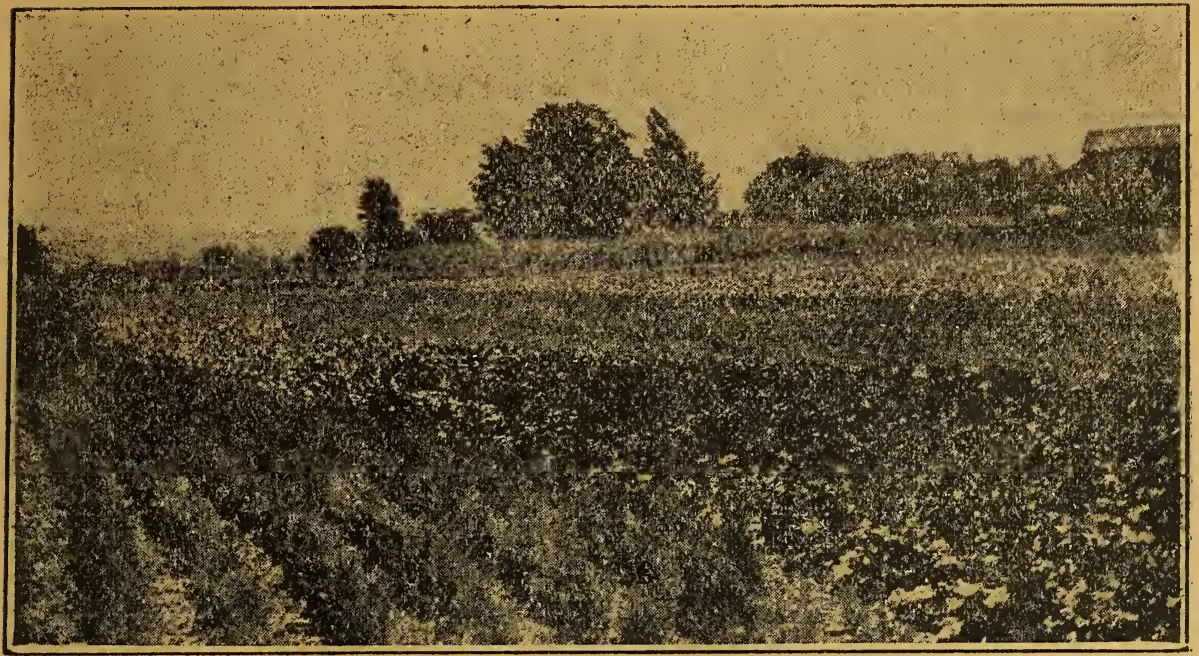

This picture shows the Garden Farm of Frank L. Scoville, Buckley Road, on Rout 1, Liverpool, N. Y., which slopes to the south and shows the city in the distarce.

Mr. Scoville has traded with us for over thirty years, as per testimonial following, and is - of the most successful market gardeners in this vicinity.

My Dear Mr. Ebeling:

I have dealt with you for so many years that I can hardly recall when I have not done so. It is eertainly over thirty years when we began and have continued to do so ever since. rhe reasen why is, that we have always found your seeds to be reliable, true to name and of good vitality. On this account you have earned the splendid reputation that your store bears in the community and wherever you do business. I would not be doing justice to myself, neither to you, were I to say anything different. Our success in gardening and farming depends se larsely upon the seedsman that we could not afford to do business with a frm that failed us in these important matters.

You are welcome to use this letter in any way that you think best. Ja.. 27th, 1917.

BARLEY

FRANK L. SCOVILLE.

Sow $1 \frac{1}{2}$ to 2 bushels if drilled; 2 to $2 \frac{1}{2}$ bushels broadeast.

MANSUREY - A productive and reliable variety. The straw is stiff and strong, holding up well and bearing long heads, which are well fill ed with plump grains. It ripens early and is goø for both feeding and malting. Write for price.

BEARDLESS BARLEY-Two row. This variety is free fro mbeards, making it easier to thresh than other kinds and safer to feed to stock. It is a strong, vigorous grower, making short, heavy straw and bearing well-filled heads. Write for price.

CHEVALIER-Very productive, popular, and a fine

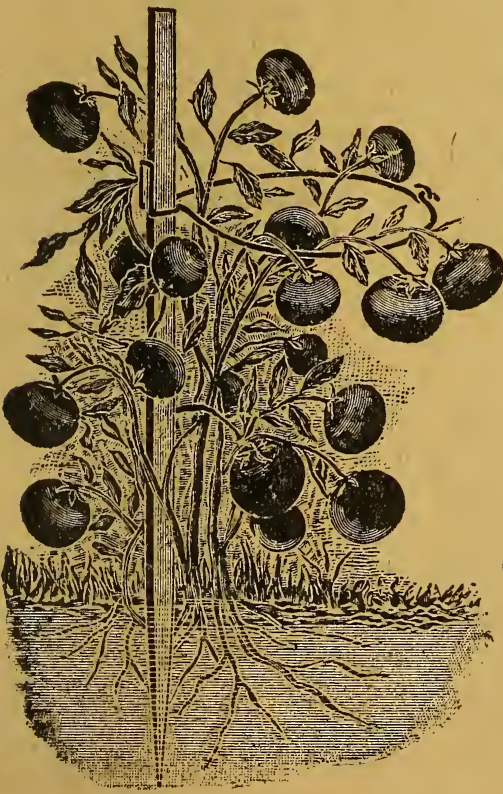
hardy 2 row type Very perrance and straw is stiff and strong. Write for price.

\section{PUTTING GREEN MIXTURE}

A careful study of the requirements for making the most substantial turf for Putting Greens developed the mixture herewith offered by us for this purpose. 'The varieties comprising it are-all of the finest-bladed, lowgrowing and most hardy kinds, and maintain their rich, green color throughout the season. We also recnmmend it for terraces, embankments and steep slopes. Per qt., 35 cts., postpaid. By express or freight, at purchaser's expense, per qt., 30 cts.; 4 qts., $\$ 1.00$; peck, $\$ 1.75$; bushel (25 lbs.), $\$ 7.00$.

\section{GOLF LINKS MIXTURE}

Made from our own formula with the object of producing a turf which will stand rough usage. For Tennis Courts, Cricket Tables, Golf Links, Polo Grounds, this seed will give perfect satisfaction. Per qt., 20 cts. postpaid. By express or freight, at purchaser's expense, per qt., 15 cts.; 1 qts., 50 cts.; peck, 75 cts.; bushel (15 lbs.), $\$ 3.00$.

\section{S. S. E. PLANT SUPPORTER}

This plant supporter will prove very useful for tomatoes, roses, hydrangeas, dahlias, and all plants requiring proper support. They are adjustable, simple, well made and offered at a low price. None can afford to be without them. Can be adjusted to the height of any plant. Will increase the quality and quantity of tomatoes, keeping them from the ground and thus avoiding. rot and other troubles.

The above cut represents the support, showing its practical simplicity, strength and cheapness. They are recommended by the best gardeners, also by Cornell University and many others.

Price, 15c each, $\$ 1.50$ per dozen. 


\section{EUAEKA ENSILAGE CORN}

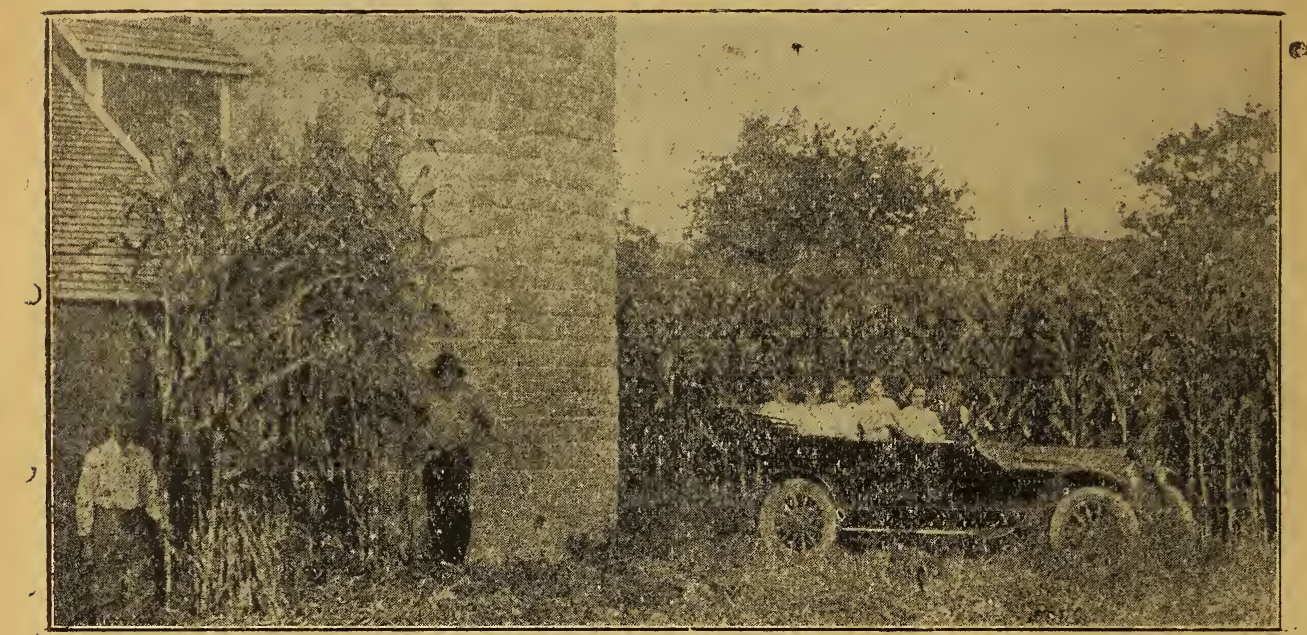

The above picture shows a field of our GENUINE and CELEBRATED EUREKA ENSILAGE CORN; also the family of the grower, Mr. H. F. Daboll of Clyde, N. Y. This shows a wonderful growth of this celebrated variety which has produced such immense crops for our New York farmers. We are offering again our genuine Eureka Ensilage corn, which we have secured from our growers in Virginia, and is not to be compared with the ordinary Southern Horse-tooth variety which is often substituted.

This Wonderful Variety of Ensilage Corn was originated and grown under special supervision on the bottom lands of Virginia. It is especially famous for abundant leaves and extreme height. Some of you will remember having seen this variety at our State Fair exhibit three years ago. The corn measured $19 \mathrm{ft}$. in height.

This season we have been fortunate in securing another carload of this wonderful corn.

As it is grown beyond the frost line it insures a perfect seed stock, as our short season does not allow it to mature and our Northern soil produces an extremely heavy growth of stalks and leaves, which makes it especially valuable ensilage and nearly double in quantity.

Bear in mind that this is the genuine Eureka, not the common Southern horsetooth variety-and remember that our stock will be exhausted early.

\section{PRICE $\$ 2.50$ PER BUSHEL \\ WHAT SOME OF OUR CUSTOMERS SAY}

Produces a wonderful growth of stalks, the tallest, most leafy and best for ensilage I have ever grown.-Isaac H. Broadhurst, Marcellus, N. Y.

Made a tremendous crop.-J. Grant Morse, Laurel Farm, Hamilton, N. Y.

Had two acres of Eureka corn and put in about 40 tons.-W. B. Sanborn, Hamilton, N. Y.

The Eureka corn we had of you this year was nearly shoulder high on July 19th and growing rapidly and will probably be 17 or 18 feet high when ready to put into our silo. We have used this for years and consider it one of the best for ensilage.

\section{Mr. F. H. Ebeling.}

SEEBER BROS. Hastings, N. Y., Nov. 1st, 1915.

Dear Sir:-I am pleased to say that the Eureka ensilage corn which I have had from you has proved more than satisfactory. The germination of the seed has been remarkably good, and the yield of corn for silage very satisfactory. silage.

With our system of growing, the ears mature fairly well and make good sweet

We are now cutting something over 160 acres of alfalfa each year. The first commercial seed which we purchased came from your predecessor, Mr. Perry, over 35 years ago, and we have had more or less seed from your store each year since. The fact that we have continued to make our purchases from you surely indicates that we have been well pleased with the seed and with the service you have given us.

Fayetteville, N. Y., December 13, 1915 . Yours very truly, F. E. DAWLEY. 


\section{Alfalfa--The BIG MONEY Crop}

It has been said many times and in many different ways that there is more money in alfalfa than in other crops. However, large numbers of farmers have been diacouraged in growing alfalfa because of weeds and because they have taken chances with inferior seeds. The truth is that alfalfa is very seldom run out by weeds. It's only the tender strains of seed that are affected. In Minnesota farmers even kill out Canadian thistle patches by seeding to alfalfa.

It's poor economy to gamble with unknown alfalfa seed when you can sow the seed grown in the great Northwest and have the results insured.

You have been warned by the U. S. Department of Agriculture against the purchase of commercial Turkestan and other inferior alfalfa seed, and you should profit by their advice. There are so many varieties and strains of alfalfa-probably more than of any other farm crop-and so many claims made for the various seeds that it is n wonder that some farmers become confused in making their selection. But isn't it logical and reasonable to believe that seed grown in a cold locality, which has survived so many handicaps but which has become world-wide famous, should bo a safe to buy? The great Northwestern alfalfa has withstood all conditions which can be met with in Central New York and in any of our eastern states, and we firmly believe it is the hardiest, heaviest-yielding and, from every viewpoint, the most productive and profitable alfalfa seed, and we are proud to be able to recommend it to our customers-and to supply them with it.

A very successful Central New York farmer has told us the method he has used in getting the finest stand of our alfalfa seed. We will pass it along to our readers. He states in part as follows:

"I plowed the ground about eight inches deep in the month of April, harrowed it the same way it was plowed, cross-harrowed it alternately each way, then I went over it with a ridging steel roller. The Alfalfa was put in with a disc drill set as deep as it would go, and the Alfalfa seed was sown ahead of the discs and was covered at least four inches deep. I followed the drill with a corrugated steel roller, leaving the ground as fine as any garden and packed close1y. When the Alfalfa first showed through the ground it had roots four inches long. About the middle of August I pulled up some of the average plants, and the roots were nine inches long. The first of October I pulled up some more of the plants and the roots were 18 inches long. I think a good many farmers fail to get a start of Alfalfa, because-first, they do not sow enough seed to the acre; second, they do not put their ground in good shape and thoroughly packed; third, they sow the seed too shallow."

We have a carload of the famous western grown Alfalfa-Dodder free-which we do not hesitate to say is the finest ever received in

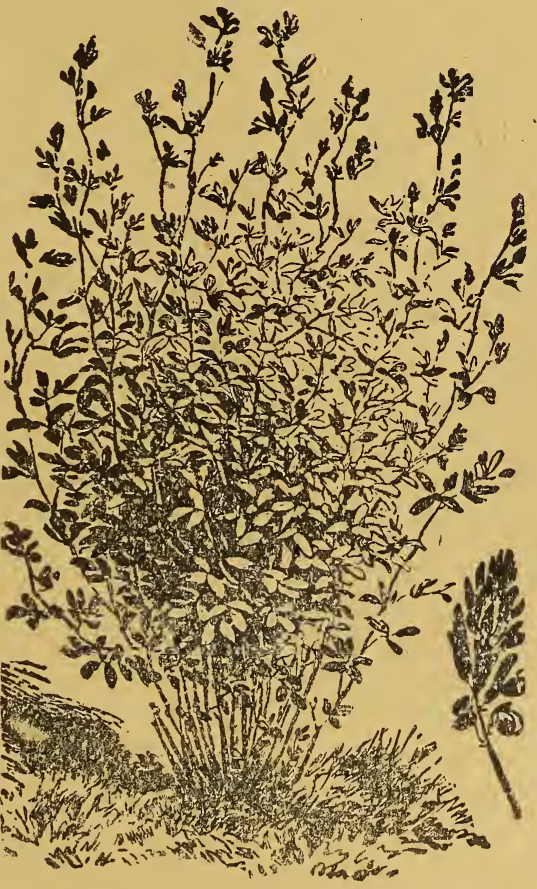
Syracuse. We trust that our customers will avail themselves of this opportunity.

Alfalfa, or Lucerne

FOR DESTROYING DODDER IN ALFALFA FIELD

Use a spray consisting of four parts of water, one part of crude carbolic acid. Mix thoroughly in hot water. Spray this on the infected spots with an ordinary paris green sprayer. If necessary spray the second time. This will kill the dodder and save about 75 per cent. of the growing Alfalfa. I am indebted to J. C. Osborn, Port Byron, N. Y., for this valuable disicovery.-F. H. E. 


\section{HAIRY OR WINTER VETCH. VIGIA VILLOSA. Makes One of the Largest Yielding and Most Nutritious Hay Crops Grown. Rivals Cow Peas in its Nitrogen Gathering Properties. A Splendid Soil Improver.}

Hairy or Sand Vetch, as it is sometimes called, we consider is one of the best annuals grown for stock feed, soil improving products, and is a cover-crop in our orchards.

Our customers tell us that Vetch is better than clover for hay and it is superlor to peas in easy curing. It gives a great abundance of nutritious food which the stock like very much. It gives fine results sown at last working of corn.

When used as a solling crop an acre of vetches and oats, rye or winter wheat, will yield from six to eight tons of green fodder which is eaten greedily by all kinds of stock.

\section{On Any Well-Drained Soil}

Our Vetch will grow on almost any drained soil and is especially adaptable for sandy and thin solls, although, of course, it will produce heavier yields on a better class of soil.

When you prepare a soil for Vetch you should see that the pulverization is tine. Alm to have the ground firm and moist. Cover the seeds about the same depth as cereal grains.

\section{Your Care of the Crop}

Vetch is usually sown from about the middle of August to the first of October; or in the Spring, usually the latter part of April to the middle of May. You may sow it broadcast or with a grain drill, at the rate of 1 to $11 / 2$ bushels of seed per acre if sowed alone.

Pure cultures for inoculating seed may be obtained free of charge from the United States Department of Agriculture.

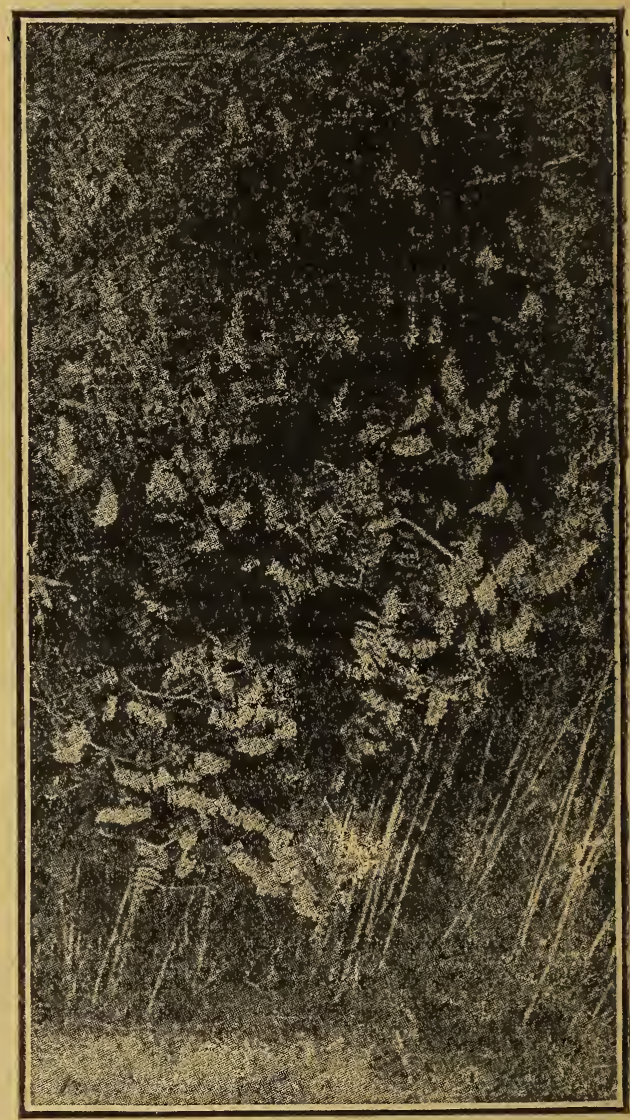

Hairy or Winter Vetch

A bushel of rye, wheat or oats per acre is usually sown with vetch so as to furnish a support to keep the vines off the ground.

The vines are very difficult to cut when sown alone, but if you sow grain as a nurse crop you can cut the combination very eariy with the mowing machine or pea harvester.

\section{Harvest and Use}

Vetch should be cut for hay just when the pods are half formed. You may cut it for green feed at the time it is in full bloom. When it is properly cured vetch makes good hay, as Its feed value is simlar to clover.

It is adapted for pasturage purposes. It will produce forage very late in the Fall and early in the Spring. Sometimes it is used for ensilage in alternating layers with green cerm. Like all other leguminious plants, vetch adds fertility to the soil and may be used in rotation with cereal and corn to good advantage. Spring Vetch, $\$ 8.00$ bu.; Winter Vetch, $\$ 9.00$ bu.

\section{QUESTION Summary ANSWER}

1. How to Sow Vetch..................... wix. with one bu. grain $25 \mathrm{~ms}$. vetch to the acre.

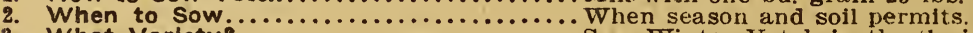

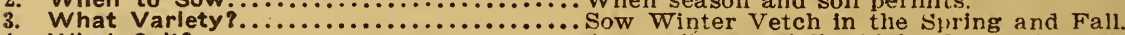

4. What Soll?........................... soil-especially ligh, dry and sandy thin

5. How much to the Acre?.............. soils are especially adapted to it.

6. How Valuable as Compared with Hay?...25 per cent greater than Clover Hay.

7. How Valuable as Compared with Alfalfa?. Three per cent greater.

8. How Valuable Compared with Ensllage?.. Four times greater.

9. Which is Best, Winter or Spring Vetch?. Winter Vetch for Spring and Fall sowing. 
Nothing is more important to the farmer than that the grass seed he sows should be pure and clean. The seed should also be plump, heavy and well ripened, so as to insure a good stand. First-class, thoroughly re-cleaned seed, while considerably more costly in the first place, is really much cheaper in the end than the light, chaffy grades generally suld at much lower prices-even should the latter be free from weed seeds. Heavy, plump seed, germinating better, will produce a much greater number of strong plants.

SUDAN GRASS. Sudan Grass is strictly an annual, and dies each year like millet, and must be seeded again each spring. This makes it fit into any system of rotation and affords a change in crop, which is a good thing for the soil. Sudan Grass is tall, reaching a height of from seven to nine feet, with very small stems, no thicker than a lead pencil. The plant stools wonderfully, and produces an amazing number of stalks from a single root. The hay crop is of great importance; stock prefer it to any other forage, and thrive on it. Produces good crops in time of drouth, and enormous ones in wet seasons. Price $50 \mathrm{c}$ tb.

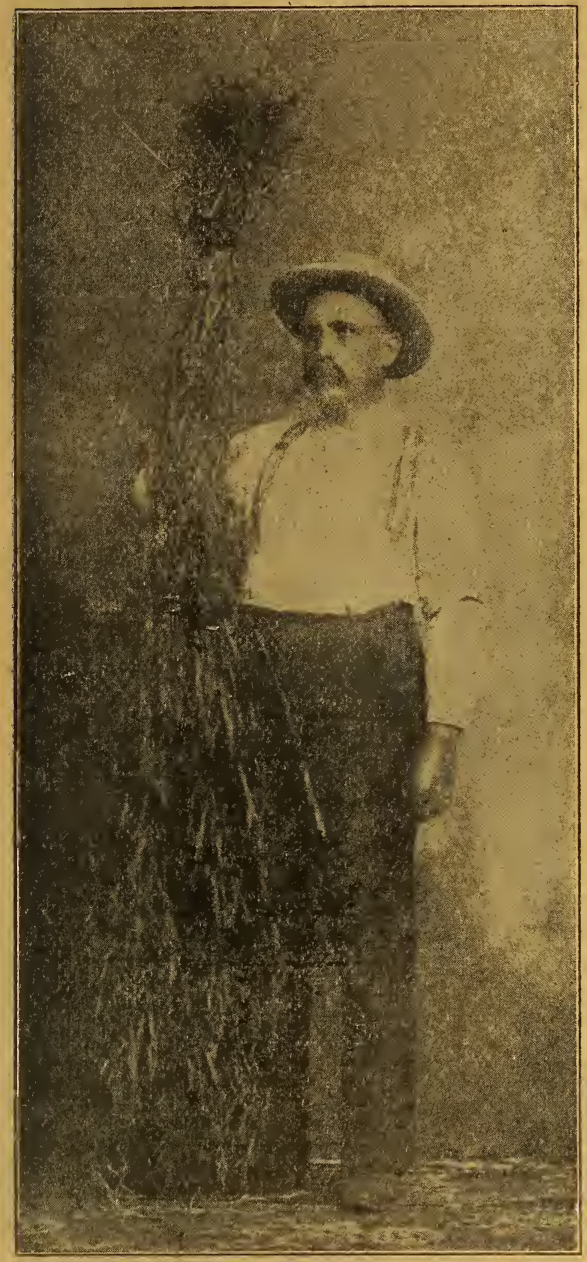

Bromus Inermls

BROMUS INERMIS. A hardy perennial, dark green soft grass, especially adapted to the dry and thinner soils. It forms a splendid grass for our Central New York farms, makIng fine pasture and good hay. It is one of the few really desirable grasses that can be depended upon for all around purposes. It is finer than Orchard Grass, sweet and nutritious, and sprouts out into fresh growth very naturally. Well adapted to high grounds, hills and sandy soil. It makes quick and strong growth, forming splendid pasturage and hay, weighs 14 pounds to the bushel. Sow three bushels to the acre. Price, $\$ 3.00$ per bushel.

It is a hardy perennial, dark green, grows on hills, dry and barren spots. It forms a splendid pasture and will grow where no other grass will thrive. Sow double the quantity of Blue Grass.

ORCHARD GRASS. (Dactylis glomerata). This is one of the most desirable pasture grasses for stock, and also for producing large crops of hay. It succeeds well in quite shady places, hence the name of Orchard Grass, Choicest re-cleaned seed, $14 \mathrm{lbs}$. to the legal bushel-but our seed is heavier; 3 bushels to the acre. Per lb., 40 cts., postpaid; per bushel of 14 tbs., about $\$ 4.00$.

TIMOTHY. (Phleum pratense). Of the easiest cultivation and with us is usually sown in connection with winter grain in the fall, to which a seeding of clover is added early in the spring. 45 lbs. to the bushel; from 12 to 16 to the acre. Per lb., $35 \mathrm{cts}$., postpaid; price per bushel, about $\$ 5.00$.

KENTUCKY ELUE GRASS. As is well known, this is the grass for which the state of Kentucky is famous and frequently in some sections of the country it is used in making lawns, although it is preeminently a pasture grass. When Kentucky Blue Grass is used for lawn purposes, the seed is generally sown at the rate of two and one-half to three and one-half bushels to the acre, and if White Dutch Clover is desired, seed should be added at the rate of one-half pound to one bushel of grass seed. Kentucky Blue Grass thrives best in well-drained or limestone soils. Legal weight, fourteen pounds to the bushel, and for pasturage it is customary to sow two and one-half bushels to the acre. Our recleaned seed weighs 20 pounds per bushel, and hence less than two bushels are required per acre. Per lb., 50 cents, postpaid; per bushel of about 20 tbs., $\$ 3.50$.

ENGLISH RYE GRASS. (Lollum perenne). This makes a quick growth very early in spring, and is adapted for cool, molst locations, recommended for fall seeding on Bermuda-grass lawns in the South, giving them a bright green appearance all winter. 24 lbs. to the bushel; 3 bushels to the acre. Per Ib. $15 \mathrm{c}$, postpaid; per bushel of 24 tbs., $\$ 2.75$.

ITALIAN RYE. (Lolium Italicum). Thls is distinct from the preceding, being of much larger and stronger growth, with large broad glossy-green blades. It succeeds best in moist, fertile soils. About $20 \mathrm{lbs}$. to the bushel; 3 bushels to the acre. Per to., 15 cts., by mail, postpaid; per bushel, $\$ 2.50$.

RED TOP OR HERD GRASS. (Agrostis vulgaris). It is a most valuable addition to sow with timothy and clover to form a close sward for pasturage. About 32 lbs. to the bushel; 1 bushel to the acre; for lawns, s bushels to the acre. Per 1b., $30 \mathrm{c}$, postpaid; per bushel of 32 Ibs., about $\$ 10.00$.

CRESTED DOGSTAIL. (Cynosurus cristatus). A valuable addition for lawn grasses which require close cutting and an ability to resist tramping, as in golf links, etc. $21 \mathrm{lbs}$. to the legal bushel; 1 to 2 bushels to the acre. Per Ib., $40 \mathrm{c}$, postpaid; per bushel of 25 tibs., $\$ 7.00$. 
CREEPING BENT. (Agrostis stolonifera). Especially adapted to moist lands and those which are occasionally overflowed. Its peculiar habit of branching underneath to the surface enables it to resist to the greatost extent tramping and pasturage. About 20 lbs, to the bushel; 2 bushels to the acre. Fer lb., 45 cts, by mall, postpaid; per bushel of 20 lbs., $\$ 7.75$.

HARD FESCUE. (Festuca durinscula). An excellent pasturage or lawn grass, succeeding well in dry or shady locations. A bout 12 lbs. to the bushel; $2 \frac{1}{2}$ bushels to the acre. Per lb., 40 cts., postpaid; per bushel of 12 tbs., \$3.50.

SHEEP'S FESCUE. Festuca avina). Slender blades growing in close, compact clumps and from six to ten inches in height. About $12 \mathrm{lbs}$. to the bushel; $21 / 2$ bushels to the acre. Per liv., 40 cts., postpaid; per bushel of 12 tbs., $\$ 5.00$.

MEADOW FESCUE. (Festuca pratensis). A tine pasture grass. About $22 \mathrm{lbs}$. to the bushel; 2 bushels to the acre. Per lb., 60 cts., postpaid; per bushel of 22 lbs, about $\$ 9.50$.

TALL MEADOW OAT: (Avena elatior). A very valuable pasture grass. It is especially adapted for rather ury, light soils. t bout $10 \mathrm{lbs}$. to the bushel: 4 to 5 bushels to the acre. Per tb., 30 cts., postpaid; per bushel of 10 lbs., $\$ 2.75$.

WOOD MEADOW. (Poa nemoralis). An excellent pasture or lawn grass, desirable for planting under trees on the lawn. $14 \mathrm{lbs}$. to the bushel; 2 bushels to the acre. Per 1 b., 60 cts., by mail, postpaid. By express: $\$ 6.00$ per bushel.

ROUGH-STALKED MEADOW GRASS (Poa trivialis). A valuable grass for moist solls or meadows, making excellent pasturage or very nutritious hay. About $14 \mathrm{lbs}$. to the bushel; 35 lbs. to the acre. Per lb., 55 cts., postpaid. By express: 45 cts. per lb.; per bushel of $14 \mathrm{lbs}$., $\$ 7.50$.

MEADOW FOXTÁIL. (Alopecurus pratensis). Closely resembles Timothy in growth, but has a soft, feathery head. It is a valuable pasture grass by reason of its rapid growth. About $7 \mathrm{lbs}$. to the bushel; 3 bushels to the acre. Per lb., 55 cts., postpaid; per bushel of 7 tbs., $\$ 4.00$.

JAPANESE MILLET. (Billion Dollar Grass.) Japanese Millet is one of the most remarkable forage plants we have; remarkable for its marvelous, luxuriant growth, often growing six feet tall; remarkable for the immense amount of hay it produces from each acre, and remarkable for its feeding value. It is adapted to all sections; does especially well on low ground; makes more hay than German or any other kind of millet, and requires less seed per acre; produces a crop in a very short time; is relished as hay by stock of all kinds; or, if allowed to ripen, will yield about as many bushels per acre as oats. The seed can be used for feed, and is especially fine for poultry. Sow in May for best results, 15 to 20 pounds per acre. If desired for hay, cut just before it heads out; or it can be left to ripen and then threshed the same as tim. othy. Price, $\$ 2.50$ per bushel.

HUNGARIAN MILLET. (Panicum Germanicum) Seed can be sown early in July to produce a good crop of hay. To make the best hay it should be cut before the seeds become hard. $48 \mathrm{lbs}$. to the bushel: 1 bushel to the acre. Per bushel, about $\$ 3.50$.

GOLDEN OR GERMAN MILLET. This is the favorite variety for planting in good land to produce a large crop of hay or forage during the summer months; of very strong growth. 50 lus. to the bushel; 1 bushel to the acre. Tennessee grown. Per bushel, about $\$ 3.50$.

DWARF ESSEX RAPE. A forage plant of highest value. It can be sown in April for an early crop, and for fall crop in July, August and September, and still later further south; it is sown broadcast $10 \mathrm{mbs}$. to the acre, but it is better drilled, in which case $5 \mathrm{mss}$. to the acre will suffice. In a few weeks from the time of sowing, sheep, hogs or cattle can be turned upon it; all reports agree that they gain welght faster on this than any other rudder, and as it can be sown after other crops are off, the gain in fodder is secured at a nominal cost. Stockmen, dairymen and farmers have proved its value. Per to. $15 \mathrm{c}$; 10 tbs., $\$ 1.50$; bushel of 50 tbs., $\$ 5.50 ; 100$ tbs. $\$ 12.00$.

SORGHUM, OR EARLY AMBER SUGAR CANE. This is the sorghum of the Northern states; makes the finest quality of syrup. The earliest and most productive variety. Height, 10 tu 12 feet. For ensilage or fodder it pussesses good qualities; stock of all kinds relish it. Sow $5 \mathrm{~ms}$. in drills, or $11 / 2$ bushels broadcast to acre. Per tb., 10c; bu. (56 tbs.), $\$ 4.00$. WINTER VETCHES, OR TARES (VICIa Villosa). Also called Sand Vetch, or Hairy. Vetch. Recommended for fall sowing with rye, which serves as a support. It is perfectly hardy in all parts of the country, remaining green all winter and maturing fully four weeks earlier than Scarlet Clover; it can, therefore, be harvested or plowed under, and the ground used for the usual spring crop. Sow 25 Ibs. with one bushel grain per acre Price per bushel, $\$ 12.00$.

\section{CLUVERS}

ALFALFA, OR LUCERNE. (Medicago sativa). It strongly resembles clover in habit of growth and feeding value, but withstands drought much better. It is a perennial. plant on well-drained soils, so that when. once established, it will continue to produce large crops for twenty years when properly cared for, and on some of the rich western prairies yields four to five large cuttings in a single season. It must be cut every time it comes into bloom, and not allowed to produce seed if permanence is desired. The plant is quite hardy, but will not succeed on low wet soils. Sow from 20 to 35 lbs. per acre. Per lb., 40 cts., postpaid. By express or freight: 30 cts. per Ib.; $10 \mathrm{lbs}$. at 28 cts. per Ib.

ALSIKE OR HYBRID CLOVER. (Trifolium hybridum). The plant is perennial and very hardy, thriving equally well on wet or: dry soils. The stems are more slender and much taller than those of the Red Medium Clover, and thus much better adapted for growing with Timothy to produce a.high grade of mixed hay. Sow at rate of 10 to 20 Ibs, to the acre. Per Ib., 30 cts., postpaid: By express or freight:per ib., $30 \mathrm{cts}$; $10 \mathrm{lbs}$. or more at 28 cts. per lb.

RED MEDIUM OR MAMMOTH. This is the common Red Clover so largely grown. We shall be pleased to quote prices at any. time.

WHITE DUTCH CLOVER. (Trifolium repens). This thrives in almost every soif and climate, succeeding equally well on heavy, moist land and thin, dry hillsides. It is of low-creeping growth and for green, velvety lawns. Per Ib., 45 cts., postpaid. By express, 60 cts. per to.

SWEET CLOVER BOKHARA (Melilotus. Alba). This slightly resembles Alfalfa in growth, but is much taller, with leafier and stiffer stems. It frequently grows five to six feet in height and branches freely, with slender ispies of small, fragrant, white flowers, which afford an excellent food for bees. Used also for inoculating Alfalfa soils.

CRIMSON OR ITALIAN CLOVER. (Trifolium incarnatum). An annual variety providing large crops of green forage, or if cut while in bloom will make excellent hay. It: should not be allowed to grow too old, or the seed-heads are liable to cause hair-balls: to form in the animals' stomachs, to thelr great injury. It is for use as a green manure and cover crops that this plant is most highly esteemed. It improves poor lands and restores to fertility those worn by excessive culture. Seed should be sown early in August. Sow $15 \mathrm{lbs}$. to the acre. $\$ 12.00 \mathrm{bu}$.

INOCULATION of these Clover Seeds means a stronger catch and better yield - see page 10 . 


\section{THE RUSSET POTATO}

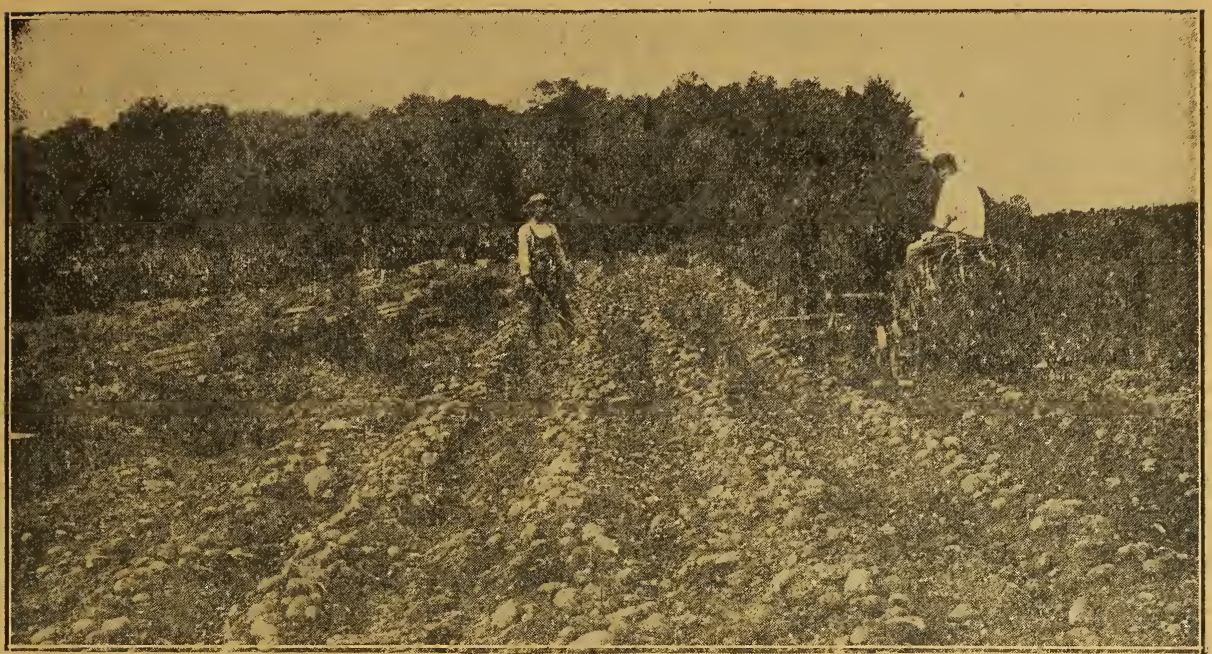

A Field of Russet Potatoes which yielded 393 bushels per acre. Grown by W. L. Hoag,

THE RUSSET IS A LATE POTATO of marvelous, robust habit of growth, the rich dark green vines cover the ground even when planted three feet apart each way, and in a dry season. Vines free from blight and not bothered with bugs. No potato known can match it in this respect. Yields enormously, producing six, eight, ten, and even twelve large-sized, round, shapely, white tubers, equal to the Rurals, Carmen or Raleigh, but a much larger producer. This potato is completely covered with a beautiful russet skin, and baked or boiled equal or superior to the best potato you ever ate. A trial of the RUSSET POTATO would convince you of the facts as stated above. Price per bushel, $\$ 3.50$. Special price for large lots.

\section{Bordeaux Mixture for Potato Blight}

3 tbs. blue vitriol, 4 lbs. lime, 50 gallons water. Slake the lime and strain it into the 50 gallons of water. Put the vitriol in a sack and put in a pail of water till dissolved; then mix with other. If bugs bother add $1 / 2$ tb. paris green. Spray once a week for six weeks.

Frank Gilson, Tully, N. Y., R. F. D. 1, has found a bug feeding on the potato bug. It has the appearance and size of a cricket with blue body, and head and neck orange. This bug destroys the potato bug and feeds on the eggs and the young bugs.' This was first discovered in 1914 by a young German in his employ, who called Mr. Gilson's attention to it. In consequence of the activity of this bug, he has had little or no trouble from the potato bugs since then.

\section{EARLY SEED POTATOES}

Early Ohio....................... ber bu. $\$ 4.00$

Early Irish Cobblers.......... “ $\quad \mathbf{4 . 0 0}$

Beauty of Hebron............ " $\quad 4.00$

\section{LATE SEED POTATOES}

Rural New Yorker..............Per bu. \$3.90

Green Mountain.

Russet

3.50

\section{Chinese or "Celery" Cabbage (Pe-tsai)}

This cabbage from China has become popular in the markets and is a profitable crop. The heads grow much like very large Cos or Romaine lettuce. The leaves have groad, thick mid-ribs which blanch perfectly white. The heads grow from a foot to eighteen inches long and weigh five to eight pounds.

Seed should not be so wnin the North until after July 1, and later farther South. If sown early the cabhage quickly runs to seed and is worthless. It is best to sow the seed in rows two feet apart and thin the nlants to fifteen inches apart. It does best if not transplanted. Oz, 35c; $1 / 4$ tb. $\$ 1.00 ;$ tb. $\$ 3.50$.

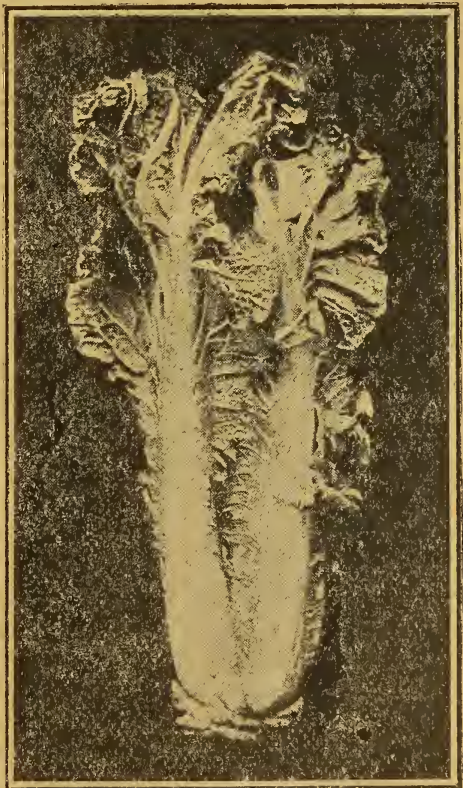

Chinese Cabbage (Pe-tsai) 


\section{Spargel (Gr.) \\ A S P A R A G U S \\ Sparagio (It.)}

Culture-Sow early in spring in rows one foot apart; when one year old the roots may be taken up and transplanted in permanent beds, which should be made by taking out the soil to a depth of about 16 inches, fill in with six inches of well rotted stable manure, then six inches of soil somewhat firmed, and place the roots on the same about 10 inches apart with the roots well spread out and cover so that the crown will be about four inches below the surface. Keep the surface well raked to keep down the weeds until the shoots appear.

Palmetto is earlier, a better yielder, and is more even and regular in its growth than Columbian Mover's. Oz. $10 \mathrm{c}$; $/ 4$ it furnishes white shoots which stay white as long as fit for use without earthing up or any other artificial blanching. Fine for canning. Oz. $10 \mathrm{c} ; 1 / 4,1 \mathrm{~b} .25 \mathrm{c} ; \mathrm{tb} .75 \mathrm{c}$.

Roots of above varieties, $\$ 1.00$ a hundred.

\section{Bohnen (Gr.) \\ BEANS-Dwarf Wax Varieties}

Faginoli (1t.)

Culture-Beans should not be planted until the ground is warm, as cold and wet weather will cause the seed to rot. For garden culture plant four or five seeds in hills one foot apart, and the rows 18 inches apart. For field culture make the rows three or three and one-half feet apart, and cover with two inches mellow soil. Do not hoe or cultivate while the plants are wet with dew or rain, as getting the leaves bespattered with earth causes rust, which injures the crop.

Pencil Pod Wax This comparatively new wax podded bean is particularly handened. Pods long, five and one-half to six inches, straight, round, fleshy, and of a bright yellow color; tender, absolutely stringless and of excellent quality, and are produced through a long season. One of the best for home use and near markets. Seed long, round, medium sized; color solid black. Pt. 35c; Qt. 60c.

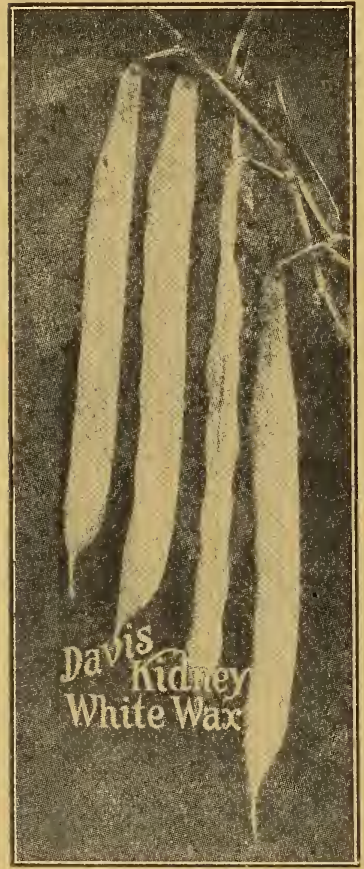

Davis Kidney White Wax
Davis Wax A very hardy and productive variety, desirmid able where a wax-podded, white seeded, sort is wanted. Vines very vigorous. Pods invariably long, six and one-half to seven inches, light yellow; seed kidney-shaped. Pt. 35c; Qt. 60c. Wardwell's Kidney Wax a little later than the Golden Wax, ylelds a large crop of long, nearly straight, broad creamy white, handsome pods. These are of large size, about six inches long, and are of good quality; kidney-shaped, white with dark markings about the eye. Pt. 35c; Qt. 60c.

Keeney's Rustless Golden Wax vines strong with short runners. Pods produced in abundance; about five inches long, stringless, light yellow, wax-like and handsome. Seed similar to a light colored Golden Wax. Pt. 35c; Qt. 60c. Currie's Rust-Proof Wax Pods straight, rather length, and of a light golden yellow; seed black. Pt. $35 \mathrm{c} ; \mathrm{Qt}$ $60 \mathrm{c}$.

German Wax, Black Seeded This variety takes place of the old Vines medium sized, with small foliage, very vigorous, hardy and productive, maturing about midseason. Pods nedium length, four and one-fourth to four and one-half inches, borne well up from the ground, curved, cylindrical, fleshy and of a clear, light golden yellow color, and remain a long time in condition for use as snaps. Seed small, oblong, jet black. Pt. $35 \mathrm{c}$; Qt. $60 \mathrm{c}$

Round Pod Kidney Wax This midseason variety and very desirable, especially for snaps for the home garden. The vines are dwarf, spreading and very productive. The leaves are roughened. The pods are long and round, five and one-half to six inches, slightly curved, light yellow, wax-like, stringless and of the best quality. They are uniformly perfect, an ill shaped one being rarely seen. Seed long, cylindrical, medium sized, nearly white, with a little dark marking about the eye. Pt, 35c; Qt. 60c.

Hodson Wax The vines of this variety are'exceedingly the pods are handsome, clear creamy white, very long, six to seven inches, straight or slightly curved, flat but fleshy and of good quality, stringless if picked when quite young; matures its crop late. Seed long, cylindrical, uniform in shape; color dull purplish red splashed with pale buff. Pt. 35c; Qt. 60c. Grenell Rust-Proof Wax Vines a little more upright and hardier than the about five inches long, broader and flatter than Golden Wax but slightly inferior in quality. Seed similar to 'our Golden Wax but darker. Very popular with some gardeners. Pt. 35c; Qt. 60c.

\section{BEANS-Pole.}

Kentucky Wonder This remarkably vigorous growing, green podded pole bean has a very long pods somewhat broad, very fleshy and quite stringless as snaps. The mature pods are often eight to nine inches in length. Seed medium sized, oval, fattened; very irregular, dark brown. The seed even from the most matured crops is usually somewhat shriveled in appearance. Its earliness and hardiness commend it as a pole bean well adapted even for northern latitudes. Its very large green pods are certainly handsome in appearance and are unexcelled in quality by any green podded bean of its class. Pt. $35 \mathrm{c}$; Qt. 60c. 


\section{BEANS-Dwarf Green Podded Varieties}

Carly Mohaw This sort is so much hardier than the others that it can be planted Carly Mohawk earlier and often will furnish beans fit for use before any other kind. Vines large, stout, with large, coarse, dark green leaves. Pods medium dark green, long, six to six and one-half inches, straight, coarse, flat, with long tapering points. Seed long, large, kidney-shaped, variegated with drab, purple and brown. Pt. 35c; Qt. 60c.

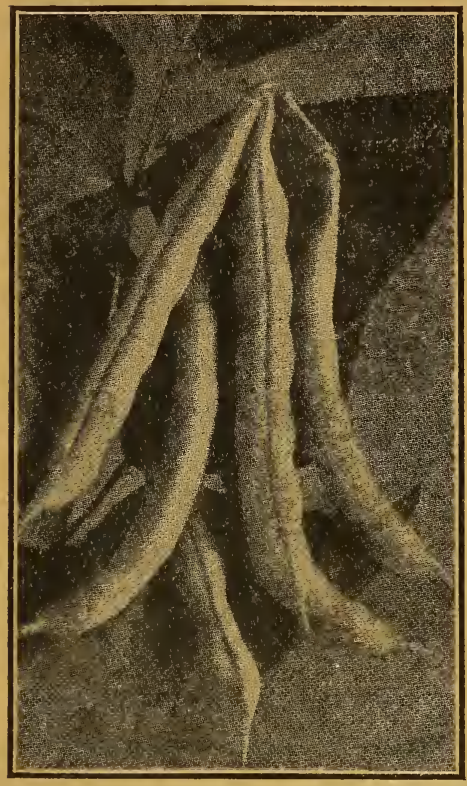

Burpee's Stringless Green Pod

Burpee's Stringless Green Pod A very green podded snap sort for the home garden and largely grown for the market. The vine is vigorous, spreading and productive. The pods are medium green, five to six inches long, larger than those of the Red Valentine but are quite as fleshy, of equally high quality and remain crisp and tender longer. They mature a little later. Pt. 35c; Qt. 50c.

Extra Early Round For snaps there is nothPod Red Valentine variety among the sorts both for the dware green podded market garden and many prefer 1 to the wax varieties. Vines medium to large, erect, with dark green leaves. Pods medium length, about four and one-half inches, curved, cylindrical, with crease in back, very fleshy, crisp and tender. Pt. 25c; Qt. 40c.

Refugee, or 1000 to 1 Of compact growth The pods are light green, very solid and tender. Pt. 25c; Qt. 45c.

Dwarf Horticultural vines very productive, large leaves. Pods five to five and one-half inches come fit for use as green shelled beans early and in this condition the beans are very large, easily shelled and are about equal to the Lima in quality. One of the best sorts for green shell beans for home and market. Pa. 30c; Qt. 60c.

Round Yellow Six Weeks, While this Improved Round Pod from Early Yellow Kidney Six Weeks in appearance of vine, pods are sliorter about four and one-half inches, much thicker, fleshier and mature earlier. Seed midum sized, round, light yellow with slightly darker marking about the eye. Pt. 35c; Qt. 60c.

\section{BEANS-Dwarf or Bush Lima}

Culture-Select land that is especially warm, rich, and well supplied with vegetable fibre or humus. Plant as soon as the soil has become warm in the spring. Make the rows 2 feet apart and give to each plant 6 inches space in the row. A top dressing of poultry manure, ashes, or some good fertilizer or compost around the plants will be of much benefit in hastening maturity and increasing the yield.

Dreer's Bush Lima A dwarf variety of the Dreer's Improved Lima. The heans 5 in a pod, and are thick, sweet and succulent. Pt. 25c; Qt. EDc.

Burpee's Bush I ima True bush form of large white Lima, bush 15 to 20 inches Burpee's Bush Lima high. 24 to 30 inches diameter, supported by its own thick stems. For productiveness and quality of beans it is not surpassed. Pt. 30c; Qt. 50c.

Fordhook Bush Lima An improved dwarf Lima of the Kumerle type. The plant ground. The pods, which are produced in large clusters, are medium green, about four and three-fourths inches long, and each contain three to five large beans of exceptionally fine quality. It is much more productive than Kumerle and matures earlier. Seed large, irregularly oval in shape, very thick, white with greenish tinge. We consider this a decided acquisition to the dwarf limas, possibly the best of the class. Pkt. 10c; Pt. 35c; Qt. 60c; 4 Qts. $\$ 2.00$.

\section{BEANS-Pole Lima}

Ideal Pole Lima One of the largest and most valuable Lima beans yet introduced. Vines unusually vigorous, very productive, bearing large clusters x to seven inches long, and containing four to six large beans of most excellent quality. While the variety matures a little later than Seibert's Early Lima, the pods are much larger and no Lima grown is more attractive. Pt. $30 \mathrm{c} ; \mathrm{Qt}$. $50 \mathrm{c}$.

King of the Garden Lima Vines very vigorous and productive. Pods five to six inches long, filled with four or five immense white 作 deners. It will come into bearing sooner and will make larger pods if not more than two vines are left to grow on a pole. Pt. $30 \mathrm{c} ; \mathrm{Qt}$. $50 \mathrm{c}$.

Seibert's Farly Iima In earliness, ease of shelling, size, beauty and quality of a the green beans, this variety is far in advance of all other 列 continues so from the very first to the last of the season; so that although the pods rarely contain more than four beans the total vield is enormous. Pods about five inches long. The green shelled beans are very large, very tender and of finest quality. Pt. 30c; Qt. 50c. Jersey Extra Early Lima Large, early and productive. Pt. 30c; Qt. 50c. 
The best results are obtained on a deep, rich, sandy loam. If wanted very early, sow such sorts as Crosby's Egyptian or Detroit Dark Red in hotbeds and transplant, cutting of the outer leaves. For general crop sow in freshly prepared soil as soon as the ground will permit, in rows eighteen inches apart covering about an inch deep and pressing the soil frmly over the seed. For winter use the turnip varieties may be sown in June so as to mature late in the season.

\section{Extra Early Egyptian The best variety Blood Turnip cellent for first early crop out Blood I urnip of doors, being very early with small tops. Root very dark red, moderately thick, a little rounded on top, distinctly flat on the bottom and about two inches in diameter when mature. Flesh dark purplish red, zoned lighter shade. Oz. $15 \mathrm{c} ; 1 / 4 \mathrm{tb}$. $30 \mathrm{c} ;$ to. $\$ 1.00$.}

\section{Early Wonder or Crosby's Egyptian}

The name of this variety is misleading, as it resembles the Egyptian only in its extreme earliness Tops small The beets are flattened globe shaped and very smooth. Exterior color of beet bright red. The flesh of our strain is bright vermilion-red, very sweet, tender and of excellent quality. It becomes fit for use sooner than any other variety. These beets mature so evenly that every beet can be pulled in two weeks. Oz. $10 \mathrm{c} ; 1 / 4 \mathrm{tb}$. $40 \mathrm{c} ; \mathrm{tb} . \$ 1.50$.

Detroit Dark Red We believe this is the Detroit Dark Red best beet for the market and home garden, and on account of its uniformly deep rich color the most desirable for canning. Tops small, upright in growth. Very smooth and of dark blood red color. Flesh is deep vermilion-red, zoned with a lighter shade of the same color. Careful comparisons with all the prominent varieties on the market in this country and in Europe prove that the Detroit Dark Red Beet is the most uniform in shape and size and the most attractive in color. It is unsurpassed in quality. Oz. $15 \mathrm{c} ; 1 / 4$ tb. $40 \mathrm{c} ; \mathrm{tb} . \$ 1.50$.

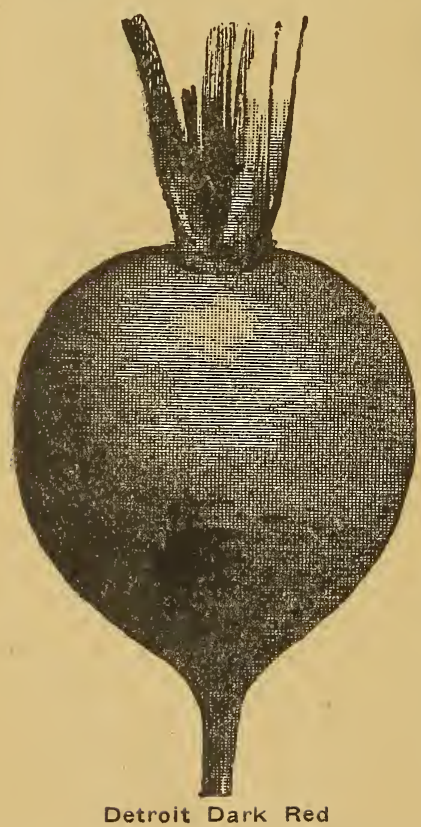

Early Eclipse An early beet especially desirable for the home garden. Tops small. Root round. Flesh bright red, zoned with pinkish white; very sweet, crisp and tender. Oz. 10c; $1 / 4$ tb. $30 \mathrm{c} ; \mathrm{tb} . \$ 1.00$.

Edmand's Early Blood Turnip Tops short and ing; ribs and leaf stalks dark red. Root nearly round; exterior color dark red, interior color purplish red with little zoning; crisp, tender, sweet and an excellent keeper. Oz. $10 \mathrm{c} ; 1 / 4$ tb. $30 \mathrm{c} ;$ tb. $\$ 1.00$.

Crimson Globe A perfect beet in all respects: shaped, with a very smooth skin, and an exceedingly small tap root, fine-grained, sweet in flavor, and tender at all times. The foliage is small admitting of close planting. Not only'a market gardener's sort, but one of the best for the kitchen garden, as it is extra early. Oz. 20c; $16 . \$ 1.50$.

\section{Bastian's Early Blood Turnip An e a r 1 y,} turnip shaped beet of very good quality. Root thick, medium sized tap. Flesh light purplish red; crisp and tendor. Oz. $10 \mathrm{c} ; 1 / 4$ tb. $30 \mathrm{c} ;$ tb. $\$ 1.00$.

Dewing's Blood Turnip Tops medium sized: , leaf green. Root dark purplish red, turnip shaped with medium sized tap. Flesh carmine with purple tinge. A medium early sort, tender, sweet and a good keeper. Oz. $10 \mathrm{c} ; 1 / 4 \mathrm{tb} .30 \mathrm{c} ; \mathrm{tb} .90 \mathrm{c}$.

Half-Long Blood A fine variety for either spring smooth, flesh bright red and winter use. The roots are use the seed should be sown early in July. Oz. 10c; $1 / 4$ to. $30 \mathrm{c} ;$ tb. $\$ 1.00$.

Swiss Chard, or Sea Kale Beet Beisskohl (Gr.) Bieta (It.) A variety of beet, juicy, tender, light colored leaves and leaf stalks, which are much superior to those of other beets for use as greens. Later in the season the broad, flat, wax-like leaf stems are cooked or pickled. This variety is wortby nf a place in every garden. Known also as Silver or Spinach Beet. Oz. 10c; 1/4 1b. 25c; 1b. $\$ 1.00$ 


\section{MANGEL BEETS, Mangel Ruben}

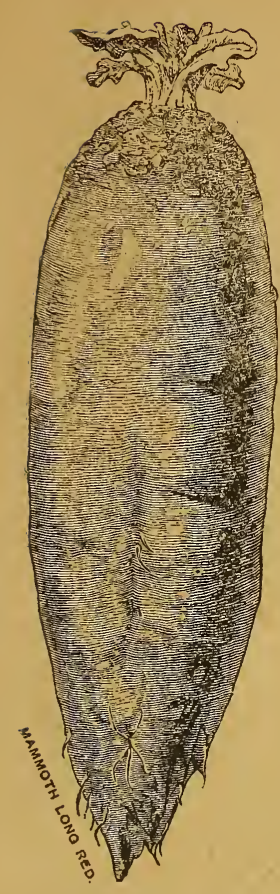

Mangel Wrumels For stock feeding. We should learn a lesson from our brother farmers in Canada and grow root crops much more extensively for stock feeding, which produce the greatest results for the labor and money invested,

Golden Tankard A smooth, yellow fleshed Mangel.' The roots Ge are of large diameter, tapering quickly at the bottom, which is quite broad, with only a small tap-root. It grows largely above the soil and is easily harvested. It yields enormous bulk on good land and can be grown closely in rows. Oz. 10c;1/4 $\mathrm{tb} .20 \mathrm{c}$; tb. $50 \mathrm{c}$.

Golden Giant, or Yellow Leviathan very fine large one-half above the surface, which renders the harvesting easy. skin a rich golden yellow, flesh pure white and sweet in flavor. It is a magnificent root easily harvested, producing enormous crops, and is a fine keeper. Oz. $10 \mathrm{c} ; 1 / 4 \mathrm{tb} .20 \mathrm{c} ; \mathrm{tb} .50 \mathrm{c}$.

Mammoth Long Red This is a heavy cropper and a large to two-thirds above the surface yielder. The roots grow from one-half in length by six inches usual diameter. Dark, richly colored foliage, skin dark red, flesh white with veined rings of rose pink. Oz. 10c; $1 / 4$ tb. $20 \mathrm{c} ;$ th. $50 \mathrm{c}$.

Yellow Ovoid The roots are of a true globe shape, from six to eight inches in diameter. Skin rich orange yellow, flesh white with lemon yellow rings. Sweet and solid. Oz. 10c; $1 / 4$ tb. $25 \mathrm{c} ; \mathrm{tb} .45 \mathrm{c}$.

Danish Sludstrup Mangel This most wonderful Mangel is a long reddish yellow root but very easily harvested, and requiring but little exertion to pull same. They frequently weigh from 15 to $20 \mathrm{lbs}$. The Danish farmers prefer them smaller, 6 to $10 \mathrm{lbs}$. each, which is accomplished by allowing less space between rows. The smaller roots contain a higher percentage of dry matter, consequently the crop is more valuable. Oz. $10 \mathrm{c} ; 1 / 4 \mathrm{~Tb}$. $20 \mathrm{c}$; tb. $45 \mathrm{c}$.

Lane's Imperial This beet will yield almost as much in bulk as the best Mangels, and contains a large percentage of sugar. Roots smooth, broad at the shoulder, gradually tapering to the base. Flesh snow-white. Oz. 10c; 1/4 to. $20 \mathrm{c} ; \mathrm{tb} .45 \mathrm{c}$. Ideal Sugar Mangel Beet The illustration faithfully show Mangel. It is perfect chunk shape of this wonderful Mangel. It is a perfect chunk of a beet, being as large at the bottom as at the top. Stands two-thirds above ground. Is easily harvested even on hard soils. This new and original Mangel has been tested alongside thirty other Mangels and by strict laboratory tests on trial

Long Red Mangel onstrations, has proven to be IDEAL and superior in

grounds and field demonstrations, has proven to b

It contains the greatest amount of sugar of any Mangel.

It grows high above ground.

It is very easy to harvest.

The IDEAL MANGEL has under favorable conditions weighed as high as thirty pounds.

Skin light yellow, flesh light yellow.

We have imported the IDEAL MANGEL from the originator in Germany for many years and this particular type can only be secured from this grower in Germany. Oz. $10 \mathrm{c} ; 1 / 4$ tb. $35 \mathrm{c} ;$ tb. $\$ 1.25$.

NOTE THE FOLLOWING TESTIMONIAL

“Syracuse, N. Y., Jan. 18, 1913.

F. H. Ebeling:

Dear Sir-I have grown Mangel Beets for years on my Homer Farm, but in recent years THE IDEAI MANGEL only, which I consider the most satisfactory, because of its large percentage of sugar, the ease of harvesting and the feeding results obtained. Last season I grew about four acres; yield $115 \frac{1}{2}$ tons of harvested Mangels. This year I intend to increase my acreage.

\section{Yours very truly,
CHARLES M. CROUSE."}

\section{B R O C C O L I}

The heads resemble somewhat a coarse caulifiower and the culture is the same in all essentials as for that vegetable. Broccoli is well adapted only to those sections where the season is long, cool and rather moist. One of the most valuable features is that it withstands sreater extremes of temperature than cauliflower.

\section{Carly Large White French i p is is}

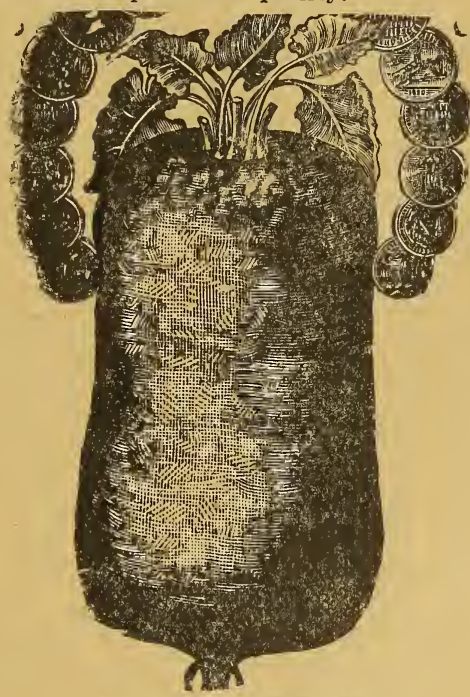

Ideal Sugar Mangel Beet the most useful variety. Plants very hardy, vigorous and easily grown. Heads white, compact, hard and of good quality. Oz. $40 \mathrm{c}$; tb. $\$ 4.00$.

Rosenkohl (Gr.)

\section{BRUSSELS SPROUTS}

This vegetable is used in the fall and and delicious than any cabbage. The plant resembles the cabbage, the edible part being the numerous very small heads or sprouts an inch or two in diameter formed on the stalk at each leaf joint. Culture is the same in all essentials as for cabbage, except the leaves should be broken down in the fall to give the little heads more room to grow.

Improved Half Dwarf Probably the most useful variety, plants growing one and pact, round sprouts of large size and good quality. Oz. 15c; $\mathrm{tb}$. $\$ 1.75$. 


\section{CABBAGE, Kopf-Kohl}

It is difficult to give definite cultural directions for cabbage, since it is possible to have good cabbage at all seasons of the year in some part of the country, and seed can be planted almost any time of the year. There are three good seasons for sowing the seed, howeverin September for late Winter and early Spring cabbages, in March for Summer and Fall cabbages, and in June and July for Winter cabbages. The seed sprouts quickly, and is likely to come up very thick in the seed bed. It should be thinned early, or the plants become spindling, and then do not head well. Transplanted to the field, they should be put twelve inches apart, in rows eighteen inches apart. To prevent the heads splitting open in the field before they are ready to be harvested, the plants should be loosened a little at the root. Cabbages require considerable moisture, but too much water causes them to rot very readily.

Early Jersey Wakefield The best early cabbage in cultivation. Forms fine solid heads of good size, pointed heads with few outer leaves.

Oz. $25 \mathrm{c}, 1 / 4$ tb. $75 \mathrm{c}, \mathrm{tb} . \$ 2.50$.

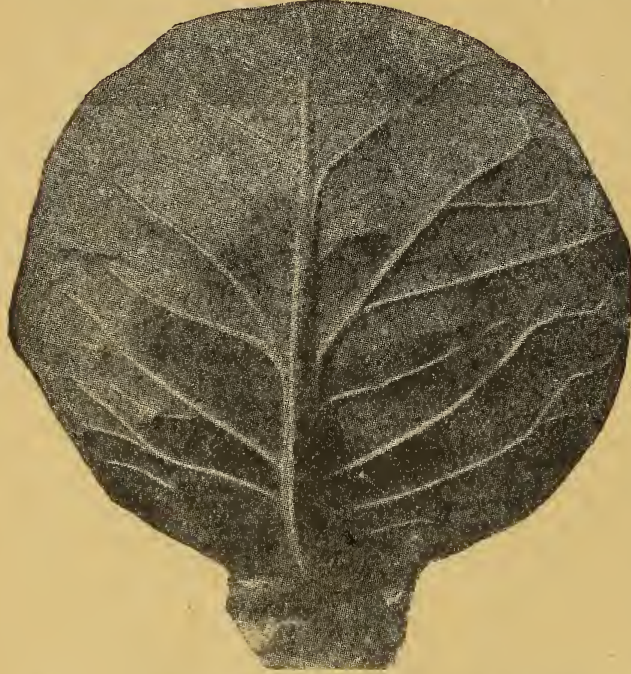

Early Copenhagen Market, from Photograph

scription is unnecessary. Oz. 25c, $1 / 4 \mathrm{~Tb}, 65 \mathrm{c}, \mathrm{tb} . \$ 2.50$. Danish Ball-Head the best cabpirg and keeping qualities. Heads perfectly round, very hard, solid and deep and of fine white color, making them different in appearance from any other sort: Quality superior to all the cabbages, and the most profitable shipping variety known. Can supply this in short or long stem. Oz. 30c; 1/4 to. $75 \mathrm{c} ; \mathrm{tb}$. $\$ 2.50$.

Henderson's Succession The iners say of this cabbage: "We consider it one of our most valuable contributions to horticulture. It would be classed as a second early variety, coming in a few days later than Early Summer, but it is supericr to that variety. It is of nearly double the size, and is absolutely true to its type under all conditions. It is so finely bred that in a field of twenty acres every hexd appears alike." $\mathrm{O} z$. $25 \mathrm{c} ; 1 / 4$ tb. $85 \mathrm{c} ; \mathrm{tb} . \$ 2.50$.

The Hollander This splendid cabthe bage is so near like that it would be difficult to tell them apart. Splendid for its keeping and shipping qualities. thus enabling the grower to supply the late spring shipping market. Oz, $25 \mathrm{c}, 1 / 4$ th. $85 \mathrm{c}$, th. $\$ 3.00$.

The Volga A valuable acquisition to Copenhagen Market This new bage is the earliest Ball-shaped variety known. Heads very solid, of wonderful quality, with small cores and weighing from 10 to 15 pounds Oz. $40 \mathrm{c} ; 1 / 4$ to. $\$ 1.25$; to. $\$ 4.00$.

Glory of Enkhuizen This second s very sure heading and of early variety ity. The plants are of vigorous growth with larse, rather spreading outer leaves which are noticeably curved and frilled. The heads are globular or very nearly round, very solid and of large size for so early a variety. Pkt. $5 \mathrm{c} ; \mathrm{Oz} .25 \mathrm{c}$; tb. $\$ 2.50$.

Early Winingstadt Pointed head An old and $75 \mathrm{c}$, to. $\$ 2.50$.

All-Head Early Our ALL-HEAD value, having fine outer leaves large, very solid, flat but very deep and uniform in size and shape. Fine for Kraut. Oz. $30 \mathrm{c} ; 1 / 4$ th. $\$ 1.00 ; \mathrm{tb}$. $\$ 3.00$.

Flat Dutch A fine, very large, late Oz. $20 \mathrm{c} ; 1 / 4$ tb. $75 \mathrm{c} ;$ tb. $\$ 2.50$.

Late Drumhead One of the oldgrowing sorts. So well known that a de-

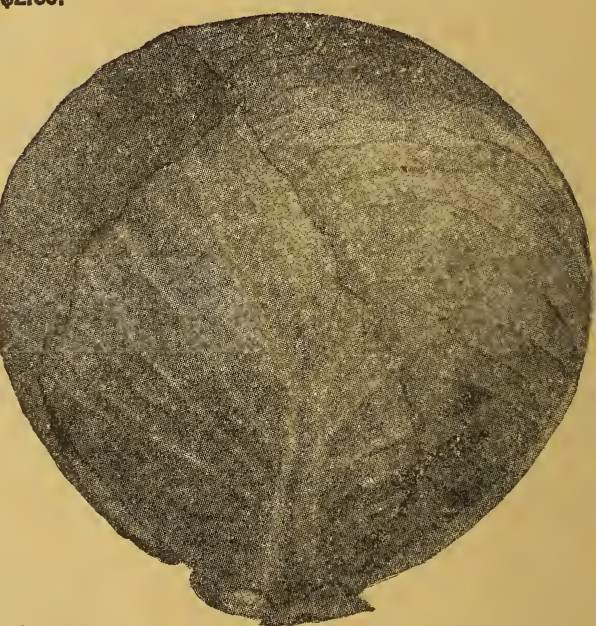

Danish Ball Head, from Photograph

heads are as round as a ball, flesh firm and tender. It matures two weeks earlier than any other of our late growing sorts, and if set out early will mature in July and August. Especially fine for kraut. Oz. $25 \mathrm{c} ; 1 / 4 \mathrm{tb}$. $75 \mathrm{c}$; tb. $\$ 2.50$.

Mhile late in maturing this has the largest heading of all Mammoth Rock Red the deep red varieties. Oz. 40c; $1 / 4$ to. $\$ 1.25 ;$ th. $\$ 4.00$.

Red Drumhead or Large Red Dutch Heads of large size, slightly rounded. to. $\$ 4.00$.

Globe Savoy The earliest and sweetest of Savoys or curled cabbages. The head is round, solid. Leaves small, thick, fleshy and of fine deep green color. American Victoria Savoy The best of the late Savoys for house use or for the much curled or wrinkled. A sure header of head Savoy. Oz. 30c; $1 / 4$ tb. $75 \mathrm{c} ; \mathrm{tb} . \$ 3.00$

Chinese or "Celery Cabbage" see page 15 . Oz. 30c; 1/4 to. 75c; tb. $\$ 3.50$. 
Blumenkohl (Gr.) CAULIFLOWER

Cavoloflore (It.)

The Caulinower delights in a rich soil and an abundance of water. Sow seed for an early summer crop in February or March in a hotbed. When plants are three or four inches high, transplant four inches apart in boxes or frames. In the middle of the spring or as soon as deemed prudent, the plants may be removed to open ground. Set plants from 2 to $21 / 2$ feet apart each way. For late Cauliflower sow the seed in a cool moist place about June 1st.

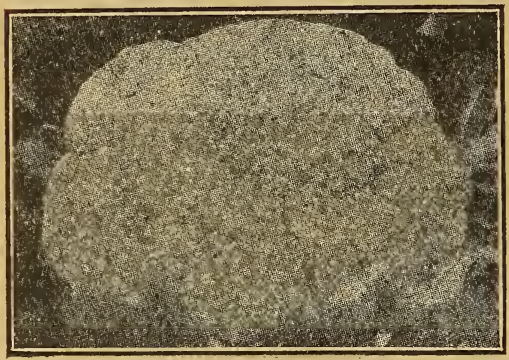

Early Snowbali Cauliflower

Early Snowball The most popular and propfamily. Heads of uniform size, snowy white, very tender, and nwing to its attractive appearance a most desirable market variety. This seed is imported from our Denmark growers under contract, being the best known source for Cauliflower seed. Oz. $\$ 2.00,1 / 4$ tb. $\$ 7.00$.

Early Erfurt Very similar to the Early Snow. equal to it. It is ball, and by some considereo worthy of a place alongside with the Snowball. $\mathrm{Oz}$. $\$ 2.00,1 / 4$ tb. $\$ 7.00$.

Extra Early Paris An excellent early sort, conditions will produce splendid results. Not as sure a header as the Snowball and Erfurt. Oz. $50 \mathrm{c}, 1 / 4 \mathrm{tb}$. $\$ 2,00$ 。

Sellerie (Gr.

Sedano (It.)

CULTURE.-Celery seed is slow to germinate, and ample time must be given. Sow thinly; cover lightly. Keep constantly moist. Count on about 7,500 plants per ounce of seed, or $1 / 4$ pound per acre. When the seedling plants are 3 inches high they should be clipped at the top, to favor stocky growth, or else transplanted. Celery is mostly grown under flat culture, without trenches, in rows 4 feet apart, 6 inches apart in row. For home use celery to often grown in double rows, 10 inches apart, without trenching, and banked for winter itorge just where it grows, without liftins.

Golden Self-Blanching This is the very best celery for early use. It is in condition as early in the fall as any, and we have yet to find an extra early sort equal in quality and appearance to our stock of Gardeners and consumers generally depend upon this variety to produce their best early celery. Plants of medium size, compact and stocky-with yellowish green foliage. As they mature the inner stems and leaves turn a beautiful golden yellow, so that blanching is effected at a small expense of time and labor. For beauty, color, crispness, tenderness, rreedom from stringedness, added to a fine nutty flavor-it has no egeual among the celery family. Oz. $\$ 1.50,1 / 4$ tb. $\$ 5.00$, tb. $\$ 18.00$.

Columbia An early maturing sort, unsurof medium height, but very stocky and heavy. The stalks are thick-almost round. Similar to the Giant Pascal. With color of a rich yellow tint. Like the Golden Self-Blanching and which it resembles when trimmed and bunched ready for market. The foliage of a light shade of green tinged with yellow. Follows the Golden Self-Blanching. Quality exceptionally fine. Some connoisseurs consider it equal to the Golden Self-Blanching. Oz. $75 \mathrm{c}, 1 / 4$ tb. $\$ 1.50,1 \mathrm{~b}$. $\$ 8.00$. White Plume A handsome, very early sort. White Plume In great demand as a market celery, owing to its very attractive appearance. Requires a short time only for blanching. Leaves light green with tips almost white. As the plants mature the inner stems and leaves turn white, and require to be earthed up but a short time before they are in condition for use. While very attractive we do not consider it equal to the Golden Yellow Self-Blanching. Oz. 20c, $1 / 4$ th. $75 \mathrm{c}$, th. $\$ 3.00$.

French Success This keeps the best of any Compact growth and short stem, so that plants may be well earthed up for blanching while growing close together. Foliage dark green, heart large and solid and formed early. Stalks white and thick, very brittle and of splendid quality. Free from stringiness. This is one of the best of late varietiesremaining in perfect condition late into the spring. Oz. $30 \mathrm{c}, 1 / 4, \mathrm{tb} . \$ 1.00, \mathrm{tb} . \$ 3.50$.

Sutton's Superb Pink English grown seed stock. Very crisp, sweet and tenđer. celery for family use. Oz. $75 \mathrm{c}$.

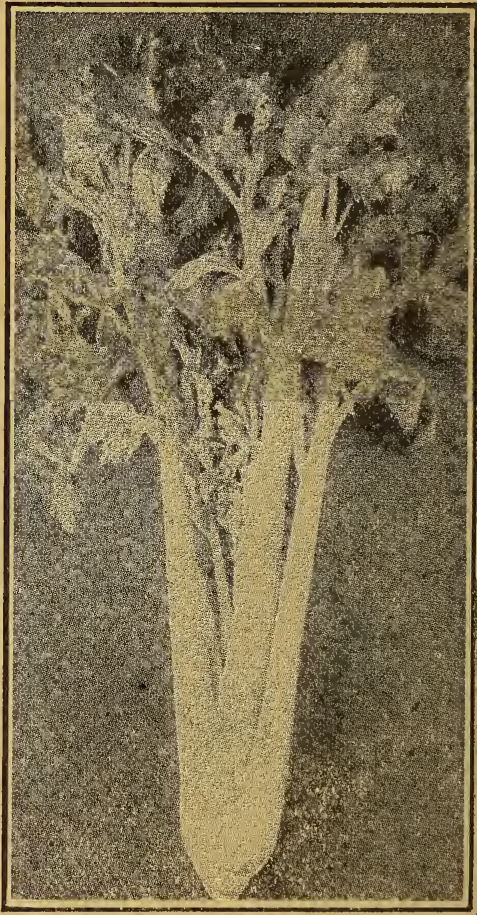

Golden Yellow Self-Blanching

Giant Pascal A splendid green leaved late variety, fine for fall and early winter use. Giant Pascal It blanches to a beautiful yellowish white color. Very solid and crisp and of a fine nutty flavor. Stalk of medium height, very thick. The upper portions nearly round. Splendid for fall and winter use, especially in the South. Oz. 25c, 1/4 tb. $75 \mathrm{c}, \mathrm{tb}$. $\$ 2.50$. Winter Queen This is without question the most valuable variety of eelery for winHFARTWELL as a winter keeper. It is also much stouter, thicker and heavier with double the amount of heart of any known celery. Oz. 25c, 1/4 tb. $75 \mathrm{c},-\mathrm{tb}$. $\$ 3.00$. 


\section{CELERIAC, or GERMAN CELERY}

Large Smooth Prague The best of all with a large smooth root of splendid Apple Shaped. Not as smooth as the Prague, but of equal quality and good form. Apple Shaped 'Pkt. 10c; Oz. 30c.

Turnip Rooted This is the most popular and best known variety. Per pkt. 5c, per Cichorien-Wurzel (Gr.)

\section{CHICORY}

Cicoria selvatica (It.)

Witloo Known in restaurants as French Endive. Sown in May and June in drills. Witloof Transplant or thin to 6 inches; treat as endive, except that late in summer
or fall it should be gradually banked up like celery. The stalks, when blanched, make a or fall it should be gradually ba
delicious salad. Oz. 20c; th. $\$ 1.50$.

delicious salad. Large leaves, suitable for Used for coffee: Improved greens. Oz. $15 \mathrm{c}$, th. $75 \mathrm{c}$.

\section{SWEET CORN}

Oz. $15 \mathrm{c}$; th. $\$ 1.00$.

Welschkorn (Gr.)

A rich, warm, alluvial soll is the best, but excellent sweet corn can be raised on any good, ordinary soil, if it is deeply and thoroughly worked before planting. In the North sweet corn should be planted as early as can be done without risking great loss from frosts or from rotting of the seed in the soil. If planted in rows, make the rows about three and onehalf feet apart and place the soll. If planted in half feet apart and place the seed fourteen to sixteented in hills, make the hills for the early varieties three feet apart each way and plant six kernels to the hill. For the later sorts the. varieties three feet apart each way and plant six kernels to the hill. For Hoe frequently, and when six inches high leave three or four plants in the hill. Give frequent and thorough but. shallow cultivation until the tassels appear.

Mammoth White Cory We consider this unquesearly corn. Ears very large for so early a variety. Stalks about four feet high, each yenerally bearing two large, finely shaped ears which become fit for use as early as those of any variety in cultivation. They are twelve-rowed, six to seven inches long, ery symmetrical and handsome, seldom with any opening between the rows at the base. Grain large, broad, very white and of remarkably good quality for such an early sort. The size and beauty of this variety give it ready sale even when the market is overstocked. Qt. $40 \mathrm{c}$.

Crosby's Early a most excellent early variety of fine and one-half inches long, fourteen rowed or more, with short nearly square grains which are very white, sweet and tender. Plants about four and one-half feet high. This is the sort so largely grown in Maine for canning and it is the use of this variety rather than any peculiarity of soil that has given Maine sweet corn its reputation for quality. Qt. 50c.

Golden Cream (Or Improved Golden Bantam). A between Golden Bantam and Country early variety. A cross similar in appearacne to Country Gentleman, but the color is rich cream, cooking to a light golden yellow. The flavor is rich, nutlike and delicious. The stalks make a rapid growth, producing from 2 to 4 ears each. This new variety possesses genuine merit and we recommend that all lovers of good corn give it a trial. Qt. 50c.

Golden Bantam A beautiful golden yellow, sweet and summer about the time of Improved Champion. A most important point in favor of Golden Bantam is that it holds its quality longer after being picked than any other variety we have tested (one of the greatest advances in sweet corn in this respect in years). As a market variety for wagon or fancy grocery trade. Golden Bantam has many points in its favor. It is of merchantable size, and in addition it possesses superlative quality. Qt. $60 \mathrm{c} ; 1 / 4$ Bu. $\$ 3.00$.

Howling Mob This corn originated in Ohio and it became so popular it was given the above or the originator of this corn, was to get as large an ear as possible, early in the season and of sweet flavor. This corn is of strong and vigorous growth, from $4 \frac{12}{2}$ to 5 feet high and has abundant foliage and generally produces to ears to each stalk Ears measure 7 to 9 inches in length with 12 or 14 rows. The corn is pearly white, usually covered with a heavy husk which extends well over the tip of the ears which affords a good protection from worms and birds. Qt. 50 c; Pk. $\$ 2.75$; Bu. $\$ 10.00$.

Kendel's Early Giant Remarkably large in ear for popular in some localities. The stalks are about five and onehalf feet high. The ears are about eight inches long, twelve rowed. The grain is rather broad and shallow, and the quality very good. Qt. 50c.

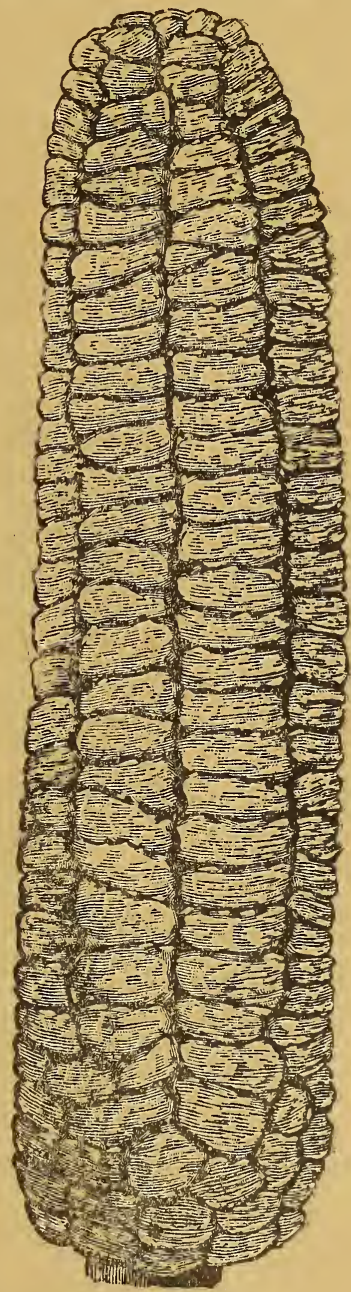

GOLDEN BANTAM CORN Perry's Hybrid This is a very popular Eastern variety. Stalks about 6 feet high, have a red or pink bearing two ears about 8 inches long, 12 or 14 rowed, which often IIttle later than Early Minnesota. Qt. 40c; 4 Qts. $\$ 1.50 ;$ Bu. $\$ 10.00$ Black Mexican This corn, when in condition for the table, cooks a bluish black. arly sort; ears about 8 inches long, usually eight-rowed. Qt. 35c; 4 Qts. $\$ 1.25 ;$ Bu. $\$ 7.00$. 
Early Evergreen We have tested many samples of Evergreen corn that were claimed Lariy Lvergreen. to be earlier than Stowell's Évergreen and to be just as good, k,t we have never found any of them so valuable as the stock of this variety we offer. It has been proven both on our trial grounds and in the field to come into fit condition for use much earlier than Stowell's Evergreen and to remain in condition quite as long. Ears about seven inches long, with fourteen to twenty more or less irregular rows with very deep grain which is of the very best quality. Plants average from six and one-half to seven feet high and in ear resemble those of Stowell's Evergreen, but differ in earliness and we think are more uniform. A standard main crop variety for home garden and market; also well adapted fur canning. Qt. 60c; 4 Qts. $\$ 2.25$; Bu. $\$ 15.00$.

Stowell's Evergreen This standard main crop variety excels all other late sort. any other for canning, for market sweetness and productiveness. It is more popular than fo be exercised in the selection of stock to grow seed from, as this variety has a tendency to deterioramakes it less sugary and desirable. We have a large and and market gardeners who must have a genuine Stowell's Evergreen, and our stock is known as the safest seed for all purposes. Qt. 60c;-4 Qts. $\$ 2.25$; Bu. $\$ 15.00$.

Country Gentleman. There is no sweet corn that compares with the Country Gencleman for sweetness. It is the variety par excellence where teners who make a specialty of growing for hotels and high class restaurant trade use this as a main crop in preference to any other. For home use it will be found superior and it is very productive. The fact that it is a favorite variety with canners proves its merit. Qt. 60c; 1/4 Bu. $\$ 2.25$; Bu. $\$ 15.00$.

Early White Cob Cory An extra early variety with remarkably white grains. Kernels are large. Of good quality. Qt. 40c; 4 Qts. $\$ 1.50$; Bu. $\$ 10.00$. Early Red Cob Cory inches long and eight-rowed and well filled are about six does especially well in the coast counties. We have customers who will not plant any other sweet corn than Red Cob Cory. Qt. 60c; 4 Qts. $\$ 1.50 ;$ Bu. $\$ 10.00$.

Feldsalat (Gr.)

CORN $\cdot$ SALAD

Large round leaved or small seeded. Oz. 10c, tb. $75 \mathrm{c}$.

Valeriana (It.)

\section{Curled CHERVIL, Gartenkerbel}

Treat like parsley. A valuable flavoring herb. Oz. 20c, th. $\$ 2.00$.

Kresse (Gr.) CRESS OR PEPPERGRASS, Kresse Agretto (It.)

Cress fine for salads.

Cress Garden curled. Oz. 10c, Tb. $75 \mathrm{c}$.

Water Cress, Dwarf Fine curled, grows in shallow water. Oz. 25c, to. \$2.50.

\section{Gurken (Gr.)}

\section{CUCUMBERS}

Cetriolo (It.)

CULTURE.-Flourish best in a rich, warm, sandy loam. Sow when danger of frost is over in hills four or five feet each way. As the young plant has many enemies sow thickly half an inch deep, and thin out finally to three or four plants to the hill. Use one ounce of seed to 75 hills, two to three pounds to the acre. Gather cucumbers by cutting, not tearing. Leave none to ripen if you want a full crop.

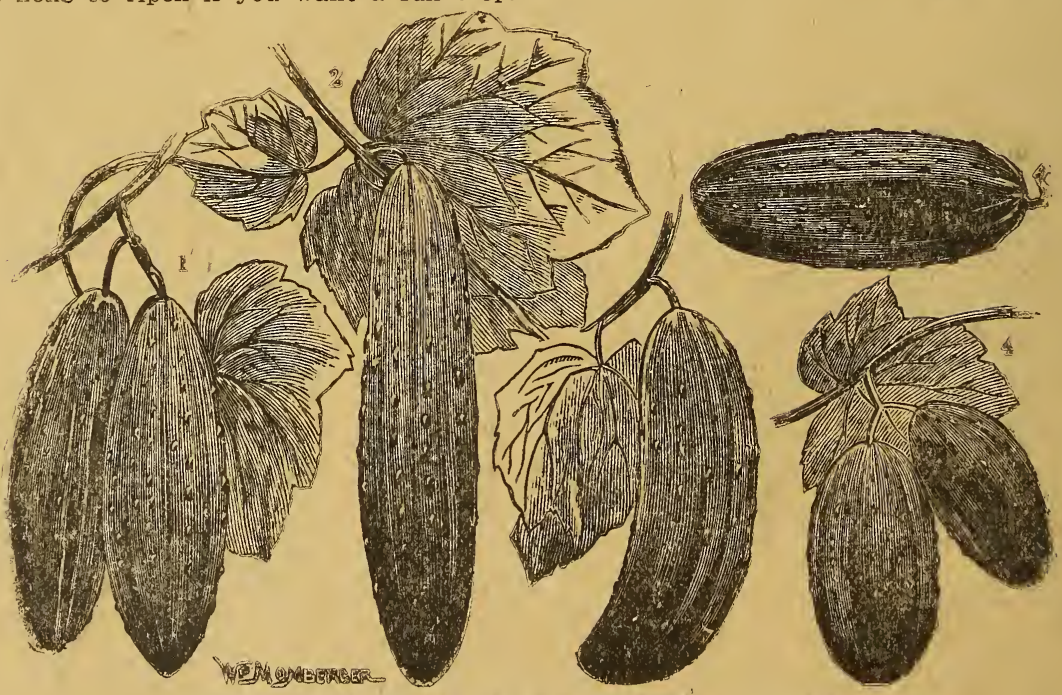

The Above Shows the True Type of Cucumbers

No. 1, Early Cluster; 2, Long Green; 3, Early Frame; 4, Early Russian; 5, Whice Spine

Early Russian The earliest variety and probably the hardiest. Fruit 3 to 4 inches Larly Russian long, $11 / 2$ to 2 inches in diameter, oval, pointed at both ends and tb. $\$ 1.00$. 
F. H. -EBELING, SEEDS AND FARM SUPPLIES, SYRACUSE, N. Y.

Early Cluster An early and very productive variety. Fruit small, thick at the end. dark green, but lighter at blossom end, borne in pairs or clusters and largely near the root. Used to some extent for pickles. Oz. 10c, 1/4 th. 30c, Th. $\$ 1.00$.

largely near the ruit short, straight, small at each end, bright Early Frame, or Short Green green, lighter at blossom end, and, although small, attractive and of excellent quality. Used both for slicing and pickling. Vine vigorous and produces fruit of suitable size for slicing. Oz. 10c, $1 / 4 \mathrm{tb} .30 \mathrm{c}, \mathrm{tb} . \$ 1.00$.

ard Improved White Spine, or A

Peerless White Spine Larger than Improved White Spine. Excellent for forcing. Fruit from 10 to $12 \mathrm{c}, 1 / 4 \mathrm{tb}$. $30 \mathrm{c}$, the $\$ 1.00$. Long Green used largely for slicing, but on account of its firmness and crispness is popular with some for pickling and is especially desirable, when mature, for sweet pickles. Vine of strong, vigurcus growth, and productive. $\mathrm{Oz} .10 \mathrm{c}, 1 / 4 \mathrm{tt} .30 \mathrm{c}, \mathrm{tb} . \$ 1.00$.

Crom A distinct variety of the hardy White Spine type. Fruit large, symCumberland metrical, dark green and thickly set with fine spines. : Though especially recommended for pickling, it is valuable for slicing, being of excellent quality. Vine vigorous, prolific, bears a long time. Oz. $15 \mathrm{c}, 1 / 4 \mathrm{tb} .40 \mathrm{c}$, th. $\$ 1.25$.

Japanese Climbing Vigorous grower, with strong, grasping tendrils which enable $1 / 4$ tb. 30c, th. $\$ 1.00$.

Boston Pickling A favorite for pickling. Medium size; smooth; light green; productive. Oz. $10 \mathrm{c}, 1 / 4 \mathrm{tb} .30 \mathrm{c}, \mathrm{tb} . \$ 1.00$.

Chicago Pickling This variety is preferred above all others by some of the largest best for the purpose, combining almost every good quality, and being alike satisfactory to grower and pickle maker. I have a choice strain of this seed. Oz. $10 \mathrm{c}, 1 / 4 \mathrm{tb} .30 \mathrm{c}, \mathrm{tb} . \$ 1.00$.

Rollison's Telegraph A standard greenhouse variety. English greenhouse grown

Small Gherkin A curious, rough, little cúcumber, used exclusively for pickling, for class quality. Oz. 20c, $1 / 4 \mathrm{tb}$. $50 \mathrm{c}, \mathrm{tb}$. $\$ 1.50$.

\section{Eierpflanze (Gr.) EGG-PLANT}

Elerpflanze (Gr.)
CULTURE.-Plant the seed in March in a hotbed, or, for family use, in flower pots in a warm window. Transplant in open ground after weather has become warm and settled, in rows two feet apart each way. They require rich soil and as favorable a location for warmth as the garden will afford. One ounce to one thousand plants.

Black Beauty ponsidered the earliest of the large fruited varieties. Color, a rich New York Improved Purple ${ }^{1 / 4}$ thorpassing all in size of fruit. Standard market

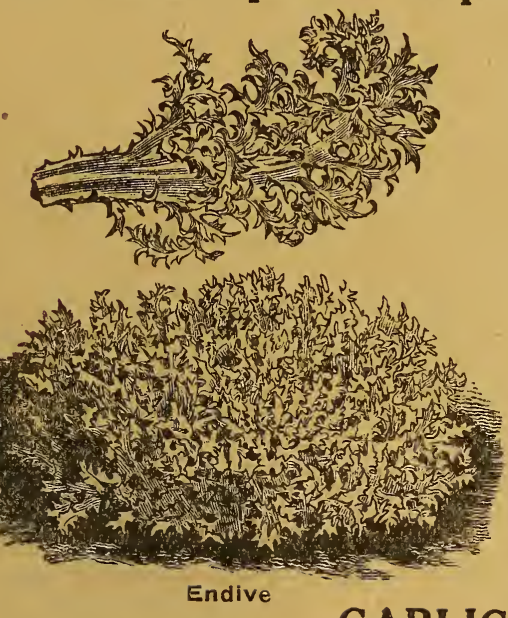

Knoblauch $(\mathrm{Gr}$ GARLIC

Sets, Oz. 10c, to. $40 \mathrm{c}$.

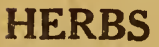

KALE,

Blaetterkohl (Gr.) Fenerally as for cabbage.

Dwarf Curled Scotch A standard variety. Oz. 10c, $1 / 4$ tb. $25 \mathrm{c}$, Tb. $75 \mathrm{c}$.

KOHL-RABI

Knollkohl (Gr.)

$$
\text { und. }
$$

Oz. $25 \mathrm{c}$, to. $\$ 2.00$

Purple, above ground.

Porree (Ger.)

Oz. $25 \mathrm{c}$, tb. $\$ 2.00$.

\section{LEEK} will sow 150 feet of drill. i. th. $40 \mathrm{c} ;$ th. $\$ 1.50$.

Aglio (It.)

See page 34

Cavolo rapa (It.)

Cavolo rapa (It.)

\section{Endivien (Gr.) ENDIVE Endivia (It.)}

CULTURE.-For early use sow as soon as the ground can be worked in the spring, in drills 15 inches apart, and thin plants to 6 to 8 inches in a row. Any common garden soil will do. To blanch the leaves, gather them carefully togeth${ }^{\prime}{ }^{\circ}$ when perfectly dry, and tie with matting or any soft fibrous material. The leaves are very highly esteemed for use as salads. One ounce

Fine Moss Curled Very ornamental. A than the London. Oz. $20 \mathrm{c} ; 1 / 4$ th. $40 \mathrm{c} ;$ th. $\$ 1.50$. London Green Curled A siandard

Broad Leaved Batavian A 1 a $\mathrm{rge}$ riety. Oz. $20 \mathrm{c} ; 1 / 4 \mathrm{tb} .40 \mathrm{c} ; \mathrm{tb} . \$ 1.50$ American Broad Fla The standard varietv. $O z$.

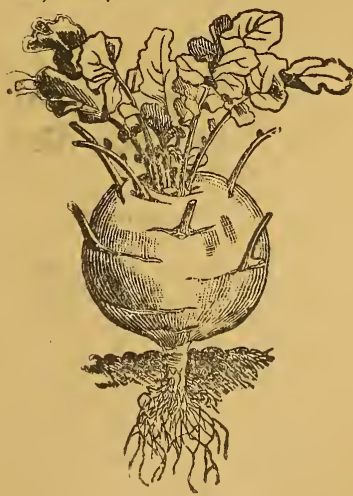

Kohl-Rabl 


\section{Kopfsalat (Gr.) LETTUCE Lohuga (It.)}

CULTURE.-Lettuce thrives on nearly all soils, but because the growth should at all times be rapid to insure crispness and best flavor, the soil should be heavily enriched and well worked before planting. Lettuce being quite hardy, seed may generally be sown as soon as ground can be fitted, as, while prolonged or continued freezing will kill the plants, they are but little injured by an ordinary frost. Seed may also be sown in the hotbed in gentle heat, and the plants, if well hardened by having been often exposed to the air, may usually be set in the open ground very soon after the time suggested for sowing seed outdoors.

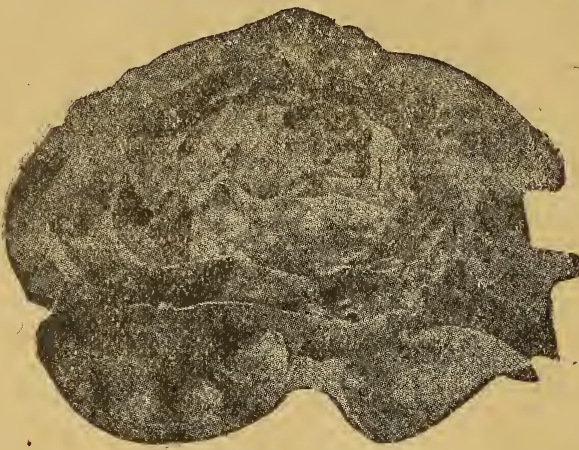

Big Boston Lettuce

Big Boston The best large heading and duces fine large yellow heads. Leaves are white, crisp, tender and sweet. Pkt. 5c, Oz. $15 \mathrm{c}$, Tb. $\$ 1.25$.

Black Seeded Simpson The most loose leaf variety. Crisp and tender. It grows a fine green leaf. The inner leaves form a loose head. Pkt. 5c, Oz. 15c, tb. $\$ 1.25$

Simpson Early Curled (W h i t very extensively used early loose leaved or clustering variety. Leaves light green, slightly frilled and much blistered. Crisp, sweet and tender. Especially adapted for thick sowing. Verv fine for poultry feeding. Pkt. 5c, Oz. 15c, to. $\$ 1.25$.

Grand Rapids (Black Seed) - As . greenhouse forcing lettuce this stands at the head of the list. Quick growing, very hardy-not liable to rot. Will remain in good condition several days after being fit for cutting. The plant is upright, forms a loose cluster of large thin bright green leaves, savoyed, finely crumpled at the edges. Very attractive and desirable for garnishing. Pkt. 5c, Oz. 15c, 1b. $\$ 1.25$

Onondaga This remarkable variety was introduced by us many years ago. A splendid Onondaga greenhouse sort, slightly fringed, forming a semi-head, a wonderful shipping and keeping variety, green under glass and of slightly reddish cast when grown in the open. Tender, crisp. Pkt. 5c, Oz. 15c, th. $\$ 1.25$.

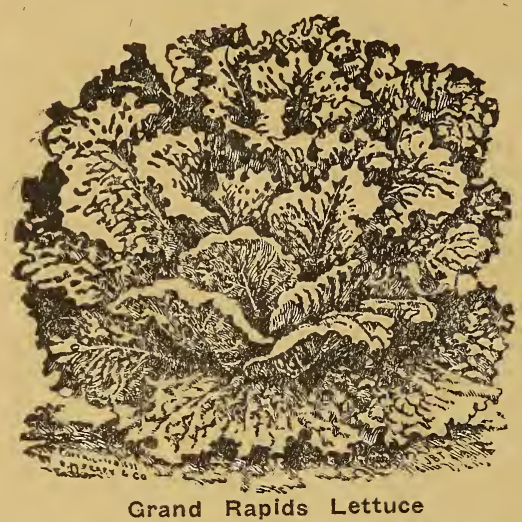

Hanson Head (Seed white.) A very detuce The plant is sirable late summer letlike head which rernains in condition longer than summer-head sorts. Outer leaves bright, yellowish green and broad. Somewhat crumpled and frilled edge and with a distinctive mid-rib. Inner leaves white, crisp and sweet. Pkt. 5c, Oz, 15c, tb. \$1.25. Paris White Cos The Cos Lettuce differs Head being in shape from other sorts. Head being elongated and of conical form, about nine inches in height and about six inches in diameter. Outer coloring yeilow green. To secure best results it should be tied up. Pkt. $5 c, 0 z .15 c$, tb. $\$ 1.50$.

Yellow Seeded Butter Cabbage Butter Yellow Seeded Butter head, medium large, medium green, leaves crumpled and rather thick. Is similar or same as silver ball. Pkt. $5 c$, Oz. $15 \mathrm{c}, \mathrm{tb} . \$ 1.25$.

Deacon Head Cabbage Butter head, medium size, medium green, torm a decided head but well folded one, which is very oily and golden yellow inside. Pkt. 5c, Oz. 15c, tb. \$1.25.

Denver Market Cabbage, butter head, medium small size, medium green. One of tical with White Seed Tennisball. Pkt. $5 \mathrm{c}, \mathrm{Oz}$. $15 \mathrm{c}, \mathrm{tb} . \$ 1.25$.

New York Head Curled or crisp as Iceberg, dark green heads somewhat conical Old Lettuce Seed for Birds oz. $5 c$, tb. $50 c$.

Melone (Gr.)

\section{MUSKMELON}

Popone (It.)

The Muskmelon succeeds best in warm, rich soil. While both plant-food and humus are The necortilizer combined supply both. If manure is used it should be rotted turf and commercial lertilizer combistributed throughout the soil. If plant-food is to well rotted, finely pulverized and evenly distributed throughout the soli.ected which, a short be supplied by the use of commercial fertilizers, then land should be selected which, a short time before, was in grass, the turf well pulverized and the fertilizer, like the manure, evenly distributed. The muskmelon should not be planted until all danger of frost is past. Plant distributed. 4 to 5 feet apart each way, allowing ten or more seeds to each hill, and cover with an from incher or these is used too freely. Thin to three or four plants to the hill.

Paul Rose, or Petoskey This excellent melon is the result of a cross of the etoskey Osage and Netted Gem, and combines the sweetness of the former with the appearance of the Gem. Fruit oval, finely netted, about 5 inches
Flesh rich orange and even sweeter than the Osage. Oz. 10c, 1/4 $1 \mathrm{~b} .40 \mathrm{c}, \mathrm{tb}$. $\$ 1.00$. 
Fmerald Gem Fruit of medium size, skin very dork green; generally smooth; flesh Emerald Gem thicker than of most varieties, in color rich saimon, and not surpassert In richness and flavor. More certain to produce uniformly good meloris than is perhaps wn. other variety. Oz. $10 \mathrm{c}, 1 / 4$ tb. $30 \mathrm{c}, \mathrm{tb} . \$ 1.00$.

Rocky Ford (Netted Gem) More largely grown the small or basket melons and shipped in enormous quantities from Colorado and Arizona. Fruit oval, slightly ribbed, densely covered with fine netting; flesh green, thick, very sweet and of rich flavor. Oz. 10c, $1 / 4$ th. 30c, Tb. $\$ 1.00$.

Improved Green Nutmeg Large, round, slightly ends, ribbed and covered with coarse netting; flesh thick, of fine flavor. Vine vigorous and productive. Oz. 10c, $1 / 4 \mathrm{th} .30 \mathrm{c}$, th. $\$ 1.00$.

Surprise Fruit oval, slightly ribbed, netted in places, good quality. Vine hardy, productive and bears early. Oz. $10 \mathrm{c}, 1 / 4 \mathrm{~Tb}$. $30 \mathrm{c}, \mathrm{tb} . \$ 1.00$.

Extra-Early Hackensack Fruit of good size,

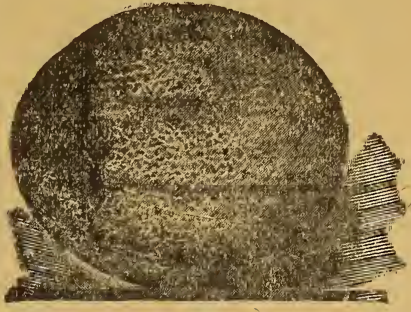

Rocky Ford Muskmelon green, a little coarse, but very juicy and sweet, and of good flavor. Vine very productiva. Oz. $10 \mathrm{c}, 1 / 4$ tb. $30 \mathrm{c}, \mathrm{tb}$. $\$ 1.00$.

Vick's Irondequoit The flesh is a beautiful dark orange, and the closely netted skin is pale yellow when ripe, giving it a most attractive appearance when exposed for sale or when cut for the table. The fruit is unusually large, in fact it is one of the largest varieties grown. The melons are distinctly ribbed and beautifully netted. The flesh is solid and very thick, having but a small seed cavity. The flavor of a well ripened "Irondequoit" is delicious, sweet, rich, spicy and melting-the very highest quality in muskmelons. $1 / 2$ oz. $25 \mathrm{c}$, oz. $40 \mathrm{c}, 1 / 4 \mathrm{tb} . \$ 1.50, \mathrm{tb}$. $\$ 5.00$. that of other varieties. Oz $10 \mathrm{c}, \mathrm{tb} .50 \mathrm{c}$.

Honey Dew Melon "Sweetest Melon Ever Grown." During the fall of 1915 the first Honey Dew Melons were placed on the market. The product netted $\$ 3600.00$ on the Chicago market. These melons have sold at wholesale from 35 cents to $\$ 1.50$ on Eastern Markets. The rind is a dull white when ripe: Part of the melon shows a slight check in the rind like a tendency to net. This appears when the melon is ready to pick. The size runs from six to seven inches in diameter from top to bottom, and eight inches in length. The matured melons are practically all of the same shape and size. Flesh is a light green and is almost honey sweet. This melon is the best of all shippers and will keep several weeks, so there is practically no loss from spoiled melons in shipping. This is one of the best market melons grown. Vines vigorous, and produces six to ten fine melons to the hill. Oz. 50c, 1/4 th. $\$ 1.75,1 / 2 \pi$ th. $\$ 3.50$.

Melone (Gr.) WATERMELON,
Sweet Heart Introduced in 1894 and is very popular as a shipping melon parfruit evenly. Fruit of largest size, oval, very heavy, rind thin but firm; color very light green. very slightly veined with a little darker shade. Flesh bright red, flrm but very tender ind sweet. Fruit remains in good condition a long time after ripening. Seed black. Our stuck will be found very uniform in shape, size and color. $0 z$. $10 \mathrm{c}, \mathrm{tb} .75 \mathrm{c}$.

Cuban Queen. This magnifirent variety was originally brought from the West Indias. oblong in form, slightly tapering at the stem in 1881 . The melons are of large stze, green. Rind quite thin, but tough enough for shipping. Flesh bright red, remarkably firm.

and of luscious quality. Oz. 10c, th. 75c. Dark lcing, or lce Rind skin. Flesh deep pink, very sweet and melting. Justly popular with New Jersey truckers, as its noted fine quality makes the melons sell well on the markets. Oz, 10c, to. $75 \mathrm{c}$.

Peerless Sometimes sold as Ice Cream. One of the best early sorts for the horne garrately vigorous, hardy, productive. shape, bright green, finely veined with a darker shade. Rind thin, flesh bright scarlet, solld, crisp and very sweet. Seed white. Oz. 10c, tb. $75 \mathrm{c}$.

Cole's Early

A very early melon; just right in size and shape. Oz. 10c, to. $75 \mathrm{c}$.

\section{MUSHROOM}

The Mushroom is an edible fungus of which there are numerous varieties. We hande the ordinary commercial variety of a creamy white color with loose gills which underneath are of pinkish-red, changing to liver color. The mushroom produces "seed" or spores and there is developed a white, fibrous substance in broken threads, called spawn, which is developed and preserved in horse manure, pressed in the form of bricks. Mushrooms can he grown in cellars, in sheds, in hotbeds or sometimes in the open air, the great essential belng a uniform degree of temperature and moisture. Our space is too limited here to give the necessary cultural directions, but these are published in book or pamphlet form.

Pure Culture Mushrom Spaw By a newly discovered process of selection Pure Culture Mushroom Spawn and grafting, the spawn is scientifically propagated so that large, vigorous and finely flavored mushrooms are reproduced. The sort wo fffer is earlier, more productive and a marked improvement on wild spawn, either French or English. Brick (about $11 / 4$ ibs.) $35 \mathrm{c} ; 5$ bricks $\$ 1.50$.

\section{MUSTARD}

White Fnglish Leaves comparatively small and smooth deeply cut or divided and or White English medium dark green color. Plant upright, of rapid growth and soon bolts to seed. Leaves, when young, are mild and tender. Seed light yellow and larger than that of other varieties. Oz. 10c; to. $40 \mathrm{c}$.

Southern Giant Curled Leaves large, light green with tinge of yellow, much crimped and frilled at edges. Plant upright or slightly good good quality. Seed small, reddish brown to nearly black Oz. $10 \mathrm{c}, \mathrm{tb} .75 \mathrm{c}$. 
Tall Mixed Garden Sometimes called Indian Cress. Grown not only for ornament for garnishing and the young but the beautiful orange colored flowers and foliage are used the young leaves or shoots are excellent for salads. The green seed pods are greatly esteemed by many for use in mixed pickles. Early in spring sow, preferably in When the young plants are about four inches high thin to six inches apart in the row. The vines can be supported if so desired by stakes, strings or brush. Oz. 10c, tb. 75c.. For other varieties of Nasturtium see flower seed pages.

\section{OKRA, OR GUMBO}

The young seed pods are used in soups, stews, , catsups, etc. Highly esteemed in the South. After danger of frost is past, the ground being warm and in good condition, plant in rows about two and one-half feet apart, covering with about an inch of fine soil firmly pressed down. When about three inches high, thin to about one foot apart in the row. Cultivate and keep free from weeds. The pods are in best condition for use when from one to three inches long.

White Velvet Plant is about three and one-half feet high, early maturing and very sized. Oz. 10c, th. 60c.

\section{Zwiebel (Gr.) \\ ONIONS \\ Cipolio (It.)}

\section{How to Raise Onions for the Market}

THE SOIL.-We prefer a soft, dark sandy loam, not too fine. This is much better if it has been cultivated with hoed crops, kept clean from weeds and well manured for two years previous, because if a sufficient quantity of manure to raise an ordinary 'soil to a proper degree of fertility is applied at once, it is likely to make the onions soft. The same result will follow if we sow on rank mucky ground or on that which is too wet, and it is impossible to raise either a large or profitable crop on stiff clay, very light sand or gravel.

PREPARATION.-Onions respond well to very liberal manuring. As much as forty loads of stock manure well composted or one ton of high grade commercial fertilizer per acre needed will vary with the soil, the seed used and the kind of onions desired. Thin seeding gives much larger onions than thick seeding. Four or five pounds per acre is the usual quantity needed to grow large onions. We prefer a drill that sows a very close row.

CULTIVATION. - As soon as the young plants can be seen in the rows give a shallow working either with rake or some other tool that pulverizes well the whole top soil. Work the crop again in a few days with a hoe or tool that cuts the ground over, this time as closely as is possible to the row without injury to the young plants; follow as quickly as possible with a thorough hand weeding.

Prizetaker Grows to an immense size and for fall marketing is unexcelled. Although of such great size, it is very hardy and a fair winter keeper, as it ripens up hard and firm; very fine grained, and of mild, delicate flavor. The outside skin is rich vellow while the flesh is white. To get the best results from this onion the seed is sown in heds and transplanted. It will, however, make a good crop if sown in the ordinary way. Oz. $20 \mathrm{c}$, th. $\$ 2.00$.

\section{Southport White Globe}

This grows to a very large size and is a perfectly globe-shaped onion. Color is a clear pure white. This variety is used by the market gardeners for bunching. Oz. $35 \mathrm{c}$, th. $\$ 3.50$.

Early Flat Yellow Danvers A good variety, but not as round or quite as early as the Yellow Globe Danvers. Very productive. Oz, 20c, th. $\$ 1.50$. Southport Yellow Globe A large perfectly shaped Globe onion and an excellent onion for keeping throughout the winter. A very heavy cropper, handsome in appearance and good dark yellow color. Oz. 25c, to. $\$ 2.50$.

\section{Yellow Globe Danvers}

This fine onion is of large size. An early and abundant cropper. Bulbs very thick, flat or slightly convex bottoms, full oval top with small neck and rich brownish yellow skin. Oz. 20c, th. $\$ 1.75$. Michigan Yellow Globe The bulbs are large and uniformly spherical with very small necks and the largest diameter below the center of the bulbs, of a rich orange color. Oz, 20c, tb. $\$ 1.75$.

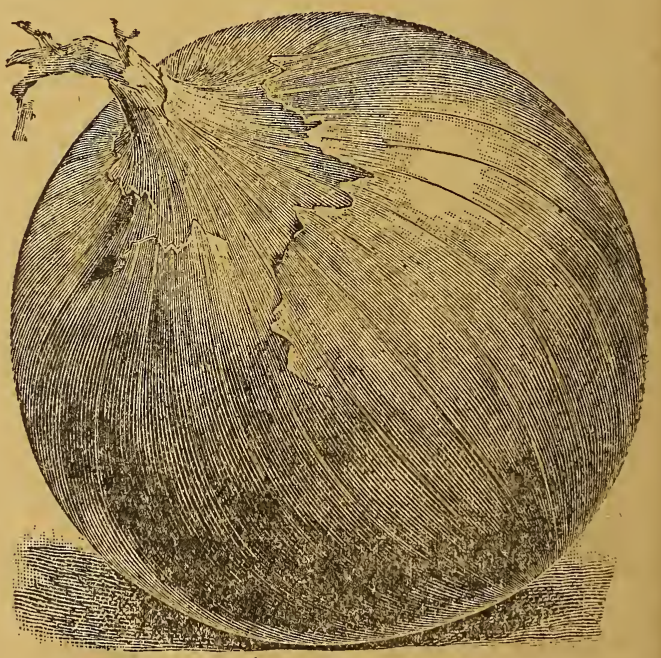

Yellow Globe Danvers Onion

Ohio Yellow Globe An early Globe onion, small neck and very uniform in size and Indiana. We have an excellent stock of this standard variety. Oz, 20c, $1 \mathrm{~b} . \$ 1.75$. Southport Red Globe This is a fine keeper. Large size and considered one of the Southport tender. Oz. 20c, th. $\$ 1.75$. 
White Portugal American Silver Skin. This is the best sort to sow-for onion sets or for pickling. When sown thickly for either it makes a small, round, hard bulb. Oz. 25c, $1 \mathrm{tb} . \$ 3.00$.

Philadelphia Silver Skin Very desirable for family use. Flavor mild and pleasare good keepers. Oz. 30c, th. \$3.25.

ant. Skin silvery white. Sets grown from this sort

Large Red Wethersfield We have a very fine and select strain of this sort. Folor is deep purplish red, flesh white, moderately Trained and very firm. Flelds an enormous amount per acre, and is one of the best winter keeping onions. Oz, 20c, the $\$ 2.00$.

Extra Early Flat Red This variety matures from ten days to two weeks earlier time grain and close. Oz. 20c, tb. $\$ 1.75$.

Petersille (Gr.)

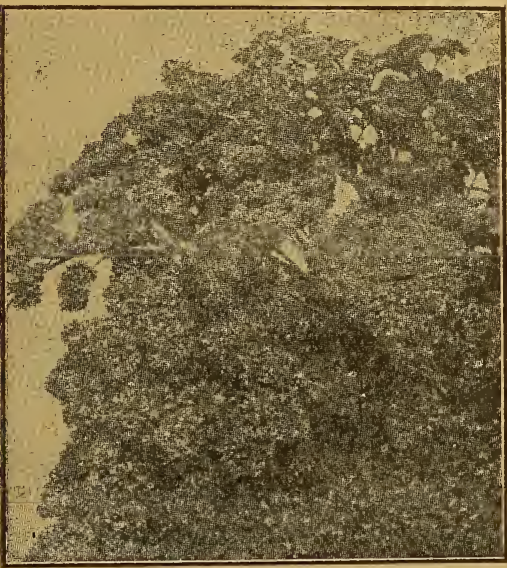

Double Curled Parsley

\section{PARSLEY}

CULTURE.-Sow seeds in shallow drills in the early spring for border, or in rows 12 to 18 inches apart, care being taken that the drills be not more than one-half inch in depth, and that the seed be well pressed down after sowing, a the seed germinates very slowly, three to five weeks elapsing sometimes before it makes its appearance. Use one ounce to 150 feet of drill, three pounds to an acre. Cultivate frequently.

Plain Parsley The leaves of this variety not curled. Very desirable for flavoring soups and stews and for drying. It is a favorite on account of its very dark green leaves, as well as its hardiness. The curled sorts are very extensively used for garnishing. Pkt. 5c, Oz. $15 \mathrm{c}$, 1b. $\$ 1.00$.

Champion Moss Curled This is compact growing variety, excellent for garnishing and flavoring. A handsome decorative plant. Leaves very finely cut and so closely crisped or curled as to resemble bunches of moss. Fine deep green color and very attractive follage. Dkt. $5 \mathrm{c}, \mathrm{Oz}$. $15 \mathrm{c}$, tb. $\$ 1.00$.

Pastinake (Gr.)

Pastinaca (It.)

CULTURE.-Sow in early spring, in rows two to three feet apart, thin to four or atx inches in the row. One ounce of seed will sow 200 feet of drill, four to five pounds per acre In drills two and one-half feet apart. Cover the seed one-half inch. Use rotted manure and ertilizer. Parsnips may be left in the ground all winter.

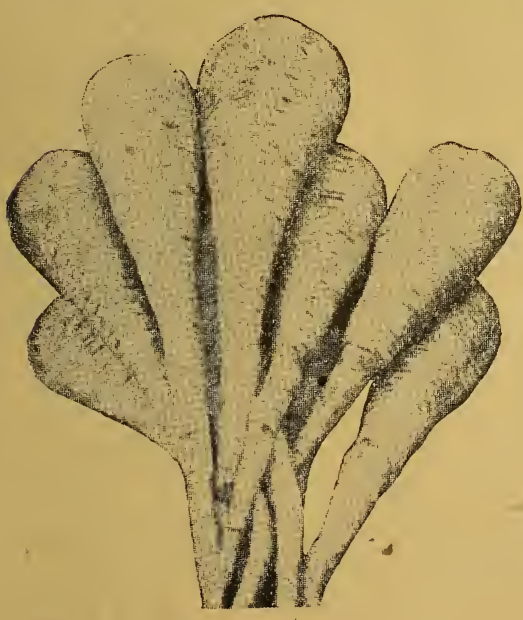

"Kelway's Don" Parsnip
Marrow Parsnip This is a fine new igin which we confidently offer to our trade. is very fine grained and exceedingly sweet, while the peculiar parsnip flavor is fully reserved. The roots are unusually smooth and attractive in appearance. The best of all parsnips for private or market garden use. Oz, 15c, th. $75 \mathrm{c}$.

Kelway's Don A half long variety of our handsome form, size, whiteness of skin and flesh, and firmness and solidity of texture. Recommended for exhibition (see lllustration). Oz. 15c, Bo. $\$ 1.00$.

\section{Gurnsey (Improved Half-Long)}

Greatly improved strain. The roots do not grow as long as the Hollow Crown, but are of greater diameter and very easily gathered. A very heavy cropper. Roots very smooth. Flesh fine grained and of excellent quality. Oz. $10 \mathrm{c}, \mathrm{tb} .75 \mathrm{c}$.

Improved Hollow Crown This really greatest old-time favorite among the parsnips and has a host of friends which it will never lose. It is very smooth, white with a very thick shoulder and tapering down to a graceful point. One of the best known, none better. Oz. 10c, to. $75 \mathrm{c}$. 


\section{Erbsen (Gr.)}

For early peas the soll should be light and warm, but for general crop a.inoderately heavy wil is better. Fresh manure and very rich or wet mucky soil should be dvoided, as they eause a rank growth of vine at the cost of the quality of the peas. such soil is often the uaise of early sorts maturing unevenly. Sow as early as pussible a fitw of some early variety on warm, quick soll, prepared the fall before, planting in lolible rows six tw eight inches apart and two and one-half to four feet between the double rows. The gelleral crop Lar be delayed until later, but we have met with better success from sowing all the varieties comparatively early, depending for succession upon selecting sorts that follow each other in maturity. The peas will give quicker returns if covered only one inch deep and where earliuess is most important they may be treated in that way. Larger pods and more of them will tie produced if the seed be planted in trenches three to six iriches deep and covered with only une or two inches of soll; when the plants are five or six inches high fill the trench level with the surface: this will secure deep rooting, prevent mildew and prolong the bearing season. If the peas be covered to the full depth at first. or if water be allowed to stand in the crenches, they will not germinate or grow well. All varieties growing mole than one and une-half feet do better if staked up or brushed when four to six inches high. The support is usually given by sharpened branches of trees set between the duuble rows.

Earliest of All, or Alaska By careful selection and growing we have developed ness in growth of vine and early maturity of pods which are filled with medium sized, bright green peas of good flavor. Vines of medium height, about two and one-half to three feet and if distinctive light color. Pods of good size, about two and one-half to two and three-fourths inches long. Seed small, smooth, and bluish green in colnr. Matures all the crnp at once and is an invaluable variety for market gardeners and canners. Qt. $35 \mathrm{c}, \mathrm{Bu}$. $\$ 10.00$.

Thomas Laxton A very early wrinkled variety of great merit. Vine vigorous, of medium height, about three feet, similar to that of Gradus, but 年 ends, similar to but larger, longer and darker than those of Champion of England and at:uniformly well filled. The green peas are very large, of fine deep color and unsurpassed in quality. We are certain that the earliness and productiveness of this pea need only to be knnwn to make it one of the most popular sorts for the market and home garden, as in appearance and quality is it one of the very best varieties yet produced. Qt. 35c, Bu. $\$ 8.00$.

Gradus A very early, wrinkled pea. Vine similar in appearance to Telephone, but of medium height, only about three to three and one-half feet. The pods are very large, about four and one-fourth inches long, very nearly as large as those of Telephone uniformly well shaped, pointed, handsome and more attractive than those of the first earlies Peas very large, of splendid quality and beautiful light green color which they retain after cooking. Practically the same as Prosperity. Qt. 35c, Bu. $\$ 8.00$.

American Wonder Vigorous, productive vines, with a luxuriant foliage, and pr..12 inches. high. On account ducing the leaves on one side of the stock, growing from 9 tn garden use. Pods are light colored, straight, round, about two and one-half inches long and blunt at the end. Fit for picking fifty-five days from planting. Seed is wrinkled, green. medium in size and square at the ends. Qt. $30 \mathrm{c}, \mathrm{Bu} . \$ 6.50$.

Nott's Excelsior Resembling Gems in habit, but more dwarf and uniform in growth, color, round, about two and one-half inches long, blunt at the ends. Fit for picking fifty-six davs from planting. Seed green, wrinkled, medium in size and square at the ends. Qt. 30c. Bu. $\$ 7.00$.

Little Marvel We are sure that as soon as American gardeners, whether for pleasure or profit, become acquainted with Little Marvel they will drop wnth Litile Gem and Nott's Excelsior, popular as these two varieties are today. The vines, of dwarf even growth. average fifteen inches in height and are heavily set with fine pois. frenuently borne in pairs. The pods average two and one-half inches in length. are square at the bottom and well filled with six to seven quite large, deep green peas. The peas are ready for the table fully as early as American Wonder or Nott's Excelsior, while the pods are larger and the vines produce a much heavier crop. All who desire a fine early cron of the choicest quality of wrinkled peas will be delighted with Little Marvel. Qt. $35 \mathrm{c}, \mathrm{Bu}$. $\$ 8.00$.

Premium Gem Desirable early green wrinkled dwarf variety similar to but better than McLean's Little Gem. The vine is very productive and grows to a height of from fifteen to eighteen inches. The pods are of medium size and crowred with six to eight very large peas of fine quality. The seed is green, large, wrinkled, often flat tened. Qt. 30c, 4 Qts. $\$ 1.00$, Bu. $\$ 6.00$.

Laxtonian This handsome new wrinkled pea is the largest podded of the dwarf vari. eties on our list. The beautiful dark green pods are similar to Gradua endid quality, are very nearly. as large in size and mature a little earlier The vines are vigorous and productive, averaging 15 to 18 inches high; foliage dark green: rinds abnut four inches in length. Seed light green, large, wrinkled. flattened, irregular in shape. Qt. $40 \mathrm{c}, \mathrm{Bu}$. $\$ 8.00$.

Potlatch Strong, vigorous vines of even growth, 20 to 24 inches in height, with luxuriant inches in length. Broad and pointed at the ends. No variety known will produce more pons. and no pods could possibly shell out better. The Potlatch is a variety from which anyone may expect great things. Fit for table use 61 days from planting. Seed green, wrinkled. large in size. We consider ourselves very fortunate in having secured and introduced this pea. Qt. 35c, Bu. $\$ 8.00$.

McLean's Advancer A green, wrinkled variety of medium height, about two and three-fourths to three inches long, which are abundantly produced and well filled to the ends This pea is used very extensively by market gardeners hecause of its productiveness, the fine appearance of its pods, and is popular with consumers on account of its quality. It is also largely used by canners. By careful selection we have developed a strain showins marked improvements in vigor of plant, size of pod and productiveness. Qt. 30c, Bu. $\$ 6.00$. 


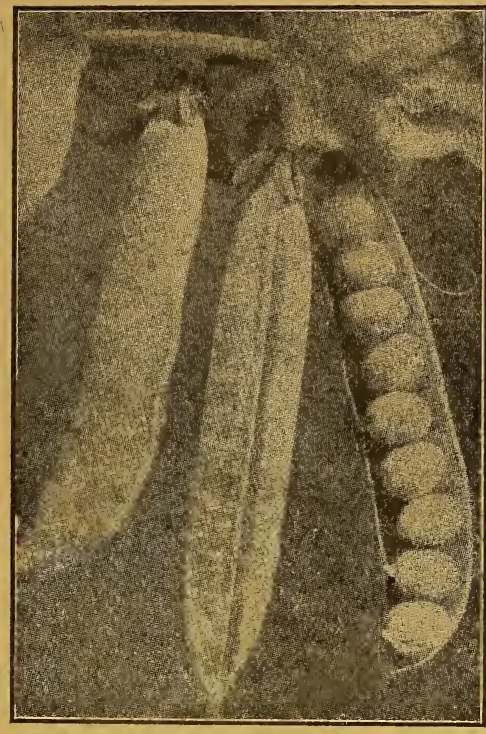

Telephone Peas

Duke of Albany A most valuable vatype; remarkably hardy in growth, producing dark green pods of large size, well filled with extra large sweet peas. The vines grow three feel in height and are very productive. Qt. $35 \mathrm{c}, \mathrm{Bu} . \$ 7.00$

Telephone This has become the leading per trade apprecites with market gardeners whose ity. Vines tall and vigorous, growing about four feet high, with large, coarse, light colored leaves and producing an abundance of pointed pods of largest size, often four and one-half to five inches long, attractive bright green, filled with very large peas which are tender, sweet and of excellent flavor. It comes into use soon after the Premium Gem and is one of the best sorts for either home or market. Qt. 35c, Bu. $\$ 7.00$.

Alderman This comparatively new pea is in many respects the very best early main crop variety of the valuable Telephone type. The vines are tall growing, about four and one-half to five feet high, dark green, vigorous and exceedingly productive. Pods of largest size, often five to five and one-half inches long, dark green, similar to but a little larger and a shade darker in color than Duke of Albany and about the same in season. The peas are of largest size and unsurpassed in quality. Market gardeners are demanding the large podded, dark colored sorts which retain their fine appearance even after shipping a long distance. The Alderman answers these requirements and furthermore is the most productive variety of this class. We recommend it unreservedly. Qt. 35c; Bu. $\$ 7.00$.

Telegraph, or Long Island Mammoth Stronger growing and hardier vine the Telephone; peas very large and of dark green color; seed almost smooth. Vods than tall, about four to four and one-half feet. Pods very large, about four and one-half inches long. A splendid sort for the market garden; will give good returns even under conditions that would cause most varieties to fail. Qt. 30 c, Bu. $\$ 6.00$.

\section{Later Varieties}

Improved Stratagem Most stocks of the large podded, semi-dwarf, English varieties of peas have been so wanting in uniformity and evenness of type as to disgust American planters, but by constant effort we have developed a stock which comes true and we do. not hesitate to pronounce it one of the best of the large podded sorts. The pods are of largest size, long and pointed, dark green, and uniformly filled with very large, dark green peas of the finest quality. Qt. $30 \mathrm{c}, \mathrm{Bu}$. $\$ 6.50$.

Horsford's Market Garden The vine is of medium height, hardy and very proon ductive, giving the greatest number of pods of any on our list. Follage dark green, leaves small. Pods contain five to seven medium sized. sweet, dark green peas which retain well their color and sweetness after canning. Qt. 30c, Bu. $\$ 6.00$.

Champion of England A very productive variety, universally admitted to be one vines are four to five feet high. The seed is light green and much shriveled. Very inferior and mixed stocks of this sort are frequently offered, but when the seed is as well grown and selected as that we offer we consider the variety equal in quality to any in cultivation and one of the best of its season, either for the home garden or market gardener. Qt. 30c, Bu. $\$ 7.00$.

\section{Melting Sugar}

(Edible pods) There is a class of peas not generally known in this country but much used abroad in which the sweet, brittle and succulent pods have none of the tough, inner lining found in the ordinary varieties of garden peas They are used in the same way as snap or string beans. Qt. 30c, Bu. $\$ 6.00$.

Large White Marrowfat The vines of this variety are about five feet high and roug ing pods are large, cylindrical, ; seed large, smooth, round and light yellow. The variety is excellent for summer use but is inferior in quality to most of the newer sorts. although undoubtedly one of the most productive of the garden varieties. Qt. $25 \mathrm{c}, \mathrm{Bu}$. $\$ 5.50$.

Large Blackeye Marrowfat An excellent variety, growing about five feet high. large, smooth, rnund, light yellow with black eye. One of the very best of the Marrowfat sorts. Qt. 25 c, Bu. $\$ 5.50$.

Pfeffer (Gr.) PEPPER

Peperone (It.)

Peppers are most largely used for seasoning meat and vegetable dishes; also for making chow chow and chill sauce. The culture is the same as for egg plant and the plants need quite as much heat to perfect them. Sow seed early in hotked, or about middle of spring in open seed bed, the soil being light and warm. When three inches high, transplant in rows about two and one-half feet apart and two feet apart in the row. Cultivate and keep free from weeds. Guano, hen dung or any other bird manure hoed into the surface soil when the plants are about six inches high will undoubtedly increase the product.

Red Cherry A second early sort. Plant tall, bearing a profusion of round, bright red in fruit. $0 . .25 \mathrm{c}, 1 / 4 \mathrm{~Tb}, 75 \mathrm{c}, \mathrm{tb}$. $\$ 2.50$. 
Giant Crimson The earliest maturing of the extremely large, red sweet peppers and surpassed by none in evenness of size and shape. The plant is viggrowing two and one-half to three feet high, larger than that of Chinese Giant and more productive. The fruits are of the largest slze, ripen earlier than any of the other very large sorts and average heavier, as the flesl is exceptionally thick. Color deep green when fruit is young, deep crimson when matured; flavor very mild. $\mathrm{Oz} .40 \mathrm{c} ; \mathrm{1} / \mathrm{s} \mathrm{m}$. $\$ 2.00$, tb. $\$ 5.00$.

Red Chili A late variety Pods bright, rich to one-half inch in diameter at the base, tapering to a. sharp point and exceedingly pungent when ripe. Oz. $25 \mathrm{c}, 1 / 4 \mathrm{tb} .75 \mathrm{c}, \mathrm{tb} . \$ 2.50$.

Long Red Cayenne A well known medium early variety having a long. Color deep green when fruit is young, bright red when ripe. Extremely strong and pungent flesh. Oz. $25 \mathrm{c}, 1 / 4$ tb. $75 \mathrm{c}, \mathrm{tb} . \$ 2.50$.

Large Bell, or Bull Nose Our stock of known variety, sometimes called Sweet Mountain, is very superior. Plant vigorous, about two feet high, compact and very productive, ripening its crop uniformly and early. The fruits are large, with thick, mild flesh of excellent quality for use in salads and mangoes or stuffed peppers. The color is deep green when fruit is young, bright crimson when ripe. Oz. $30 \mathrm{c}, 1 / 4$ tb. $\$ 1.00, \mathrm{tb}$. $\$ 3.00$.

Ruby King An improved American variety, plant is about two and one-half feet high, vigorous. compact and productive. The fruits are often four to four and one-half inches long and of deep green color when young, bright red when ripe. The flesh is thick and mild flavored. One of the best varieties for mangoes or stuffed peppers. Oz, 30c, $1 / 4$ tb. $\$ 1.00$,

to. $\$ 2.75$. Sweet Spanish A late maturing and attractive, red, sweet pepper. Plant

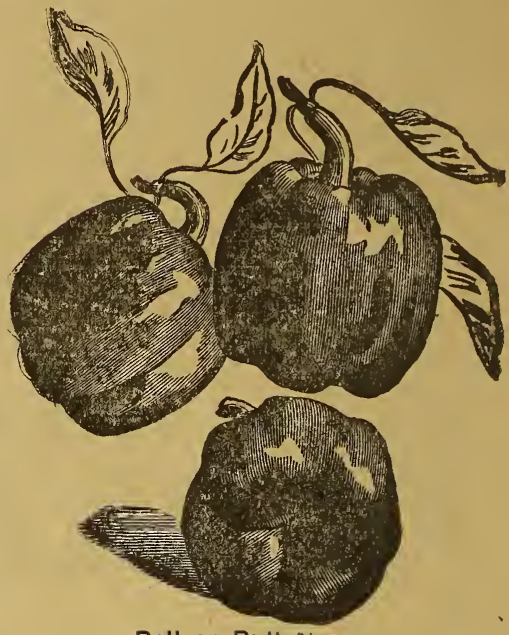
vigorous and productive. Fruits very large and one-half feet high, upright, very compact, about two inches in diameter, with very thick, mild flesh of excellent quality. Color deep green when fruit is young, rich red when ripe. Oz. $25 \mathrm{c}, 1 / 4 \mathrm{tb} . \$ 1.00, \mathrm{tb} . \$ 3.75$.

Kartoffel (Gr.)

POTATOES

Patate (It.)

Irish Cobbler Is the best early white potato grown. The tubers are smooth, round, Per Bu. $\$ 4.00$.

True Early Rose The Early Rose is the old standard early potato; rosy blush skin, keeper. Bu. $\$ 4.00$.

Late Russet The famous "Russet" recently introduced from Michigan yielded 898 Late Russet bushels to the acre on a Tully farm in 1914, many specimens weighing 15 to 20 ounces. Most vigorous grower and an immense yielder It is bug proof and blight proof. Has a russet skin; flesh white as snow. A fine cooker. The most valuable late sort on the market. Bu. $\$ 3.50$. For further particulars see page 15 .

Carman No. 3 Another large, round, white, main crop potato; tubers are very large. large potatoes. Bu. $\$ 3.50$.

Melonen-Kuerbiss (Gr.)

PUMPKIN SEEDS

Zucca (It.)

Connecticut Field per to ...........\$.40 Cashaw Pumpkin, fine table, per Io......60

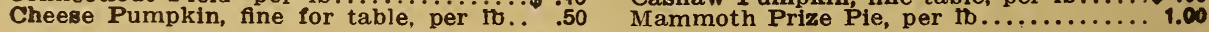

Radies (Gr.)

RADISH

Ravanello (It.)

Being a root crop, good brittle radishes require light, well-worked soil, made very rich and mellow to insure quick growth. If permitted to grow slowly, they become tough and pithy. They are easy to grow and frequent plantings will insure a constant supply for the table. Summer varieties can be sown all spring and well into summer. Winter. varieties, however, require some time to mature, and the seed should be planted in August and September for good radishes in November and December.

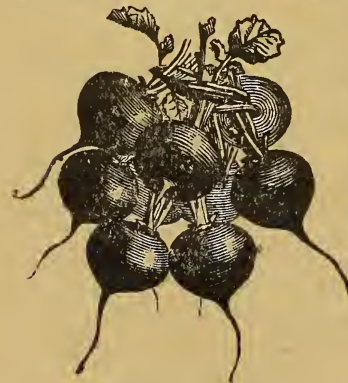

Deep Scarlet Turnip Radish Small Top-New
Johnson's Perfection Red White tipped, turnip shaped. This radish is a remarkably attractive variety. The white tip extends nearly half way up the root, and the brillinat color of the top shows up in strong contrast. Excellent for market work. Oz. 10c, Th. 75c. Early Scarlet Turnip A good, scarlet. turnip-shaped Lariy Scarlet 1 urnip radish. It is of very quick growth, and of a very desirable size, with small tops. Suitable for growing outdoors or for forcing. Oz. 10c, to. $75 \mathrm{c}$.

Vick's Scarlet Globe This grand radish has established a reputation as a forcing sort. It pecullarity is that it will bear the heat requisite for forcing without becoming pithy in character or suffering injury to its flavor. Its attractive shape is shown in the illustration. Its color is a rich scarlet. It has a small top and is a high bred radish. Oz. 10c, tb. $75 \mathrm{c}$.

Crimson Giant Forcing A new variety which will be garden variety, since it matures very popular market and home crisp much lon, than other short varieties. Color, rose carmine with white tip. It is top-shaped. Oz, 10c, ito. $75 \mathrm{c}$. 


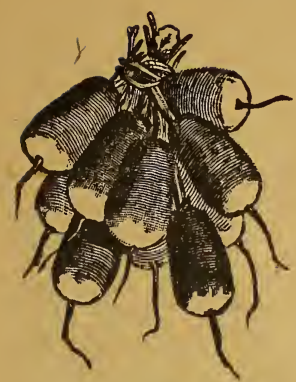

French Breakfast

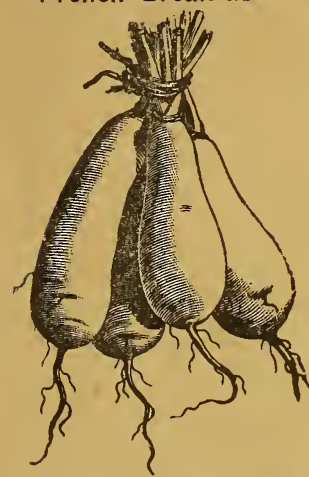

Chinese Rose Winter

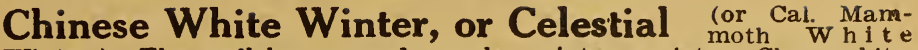
Winter.) The well-known and popular winter variety. Clear white, about four inches long and half stump-rooted. Keeps firm and crisp until it runs to seed. Is a good cooking variety, and when cooked the flavor resembles turnip. Oz. $10 \mathrm{c}$, to. $75 \mathrm{c}$.

Chinese Rose Winter A bright scarlet winter variety. rooted. Matures two or three weeks earlier than the Chinese White Winter and like it is firm and crisp and does not grow pithy until it runs to seed. Oz. $10 \mathrm{c}, 1 \mathrm{~b} .75 \mathrm{c}$.

Brightest Long Scarlet A very showy, long variety. Is Bright rose scarlet with distinck at the shoulder and taperFrench Breakfast A popular variety for market or forcing. stump-rooted. Color, bright rose with bottom of root and the tail pure white. Oz. 10c, tb. $75 \mathrm{c}$.

White Strasburg A white radish, of large size, good quality, recommend White Strasburg for summer planting heat. I always solid, with good flavor, when others fail. Popular with market gardeners. Oz. $10 \mathrm{c}$, th. $75 \mathrm{c}$.

Giant Stuttgart This mammoth white radish is the largest of the turnip shaped sorts. It has solid, radish of high flavor. Both skin and flesh are pure white. It should be given plenty of space in the row. Oz. $10 \mathrm{c}$, th. $75 \mathrm{c}$.

Icicle A handsome white varlety, about 5 inches long, with slopmild in flavor. Oz, 10c, to. $75 \mathrm{c}$.

Early Round Dark Red, or A bright scarlet turnipPrussian Globe quick growing, and a handsome radish. Round Black Spanish A winter variety, with black skin or almost globular. Oz, 10c, to. 75c. Black Spanish, Half Long A shorter, olive-shaped root and sloping top. Oz. 10c, tb. $75 \mathrm{c}$.

Rhabarber (Gr.) RHUBARB

Rabarbara (It.)

CUITURE.-Plant roots four feet apart each way, in very rich, well manured soil. Cultivate well and top-dress liberally. Plants easily grown from seed. Sow in drills about 18 inches apart, and thin the plants to 12 inches in the drills. Use one ounce to 75 feet of drill. Victoria A good market sort, with beautiful red stalks. Pkt. 5c, Oz. 15c, 1/4 tb. 40c, paid, $\$ 1.25$ per dozen.

\section{S A G E}

A hardy, perennial shrub, with whitish-green, oval, and very much wrinkled leaves, which heve pleasint smell and which are used for seasoning. It is easily grown and the seed can be sown almost any time. Its fragrant, purplish flowers are especially attractive to bees. and the finest white honey has its source in sage blossoms. Oz. $25 \mathrm{c}, \mathrm{tb}$. $\$ 1.75$.

Haferwurzel (Gr.) SALSIFY, or VEGEIABLE OYSTER Sassefrica (It.)

CULTURE. - Sow early and deeper than parsnip, otherwise culture is the same and, like that, roots, if desired, may be left in the ground through the winter, but should be dug very early in the spring. as they deteriorate rapidly after growth commences.

Mammoth Sandwich Island Larger, of stronger growth, and less liable to oz. $15 \mathrm{c}, 2$ ozs. $25 \mathrm{c}, 1 / 4$ tb. $30 \mathrm{c}$, tb. $\$ 1.50$.

Spinat (Gr.) S PINACI

Spinace (1t.)

An easily grown plant, the seed of which may be planted in the fall to secure good spinach early in the spring or even throughout the winter. The better and richer the soil. the larger and more tender the leaves will be. As a fleld crop for the market garden, use $y$ pounds of seed per acre. For the home garden use one-half ounce for 100 feet of row.

Bloomsdale Savoy The variety most generally used in the East, and especially thick very much savoyed throughout the South for shipping. Leaves large, round and Oz. $10 \mathrm{c}$, 16. $75 \mathrm{c}$.

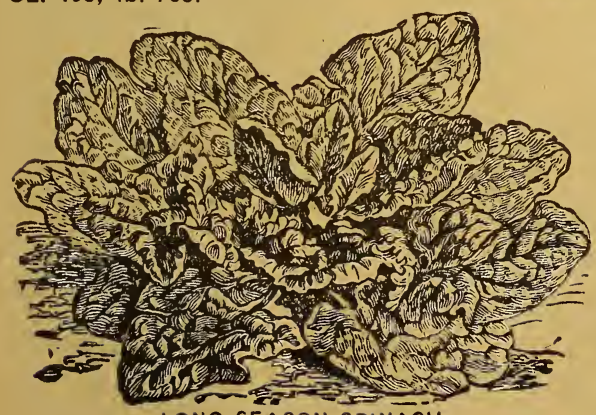

LONG SEASON SPLNACH.
Long Standing A deep green variety smooth leaves. Seed, round. Stands a long time without running to seed. Oz. $10 \mathrm{c}$, th. $75 \mathrm{c}$. Victoria A long-standing variety with Deep green round, slightly savoyed leaves. leaves early and continues to produce leaves for a long period. Oz. $10 \mathrm{c}$, $\mathrm{tb} .75 \mathrm{c}$.

Norfolk Savoy Forms a dense rosette of thick, tender and succucolnr. With this variety spinach may be continuously grown in any home garden. The hest variety to be sown in the spring and at intervals for a successional summer supply. It is Invaluable tn both home and market gardeners. Oz. $10 \mathrm{c}$, th. $75 \mathrm{c}$. 
Prickly The variety commonly used for market in California. Is very hardy and easily grown; bears large, smooth leaves, which are shaped like an arrow point. Color, New Zealand A plant with thick, fleshy texture and soft crystalline leaves. New Lealand Is not like the ordinary spinach in appearance, but it is used in the same way. Oz. 10c, tb. $\$ 1.00$.

Round, Thick Leaved A large-leaved, bright green variety.. Leaves rather smooth summer. Seed round. Oz. 10c, 1b. $75 \mathrm{c}$.

Kuerbiss (Gr.)

SQUASH

Zucca (It.)

The summer varieties come into use early in the summer, but being sensitive to frust the seed cannot be sown until late in April. The seed should be planted in hills four feet apart, using four ounces to 100 hills. The winter varieties are also unable to resist frost, and should be planted at the same time. The fruit does not mature until late in the fall, and, having a very firm, hard shell, keeps well, and with a little care squashes can be had all winter and until late in the spring. In gathering winter squashes, it is important to protect the stems, since if broken off the fruit will not keep so well. Plant in hills six to eight feet apart, using two or three seeds to the hill. Use eight ounces to 100 hills, or two pounds to an acre. Moderately rich soil will grow good squashes.

Mammoth Summer Crookneck A large golden-yellow variety, thickly warted, This is an is eighteen inches lung. brittle and tender. is an improved strain of the old variety and considerably larger. Oz. 10c, tib. $\$ 1.00$.

Burpee's Fordhook Squash A most desirable running variety for hoth summer growth and wonderfully productive. Fruits oblong in form, elght to ten inclies in lengih slightly ridged, smooth thin yellowish skin; flesh very thick and of a light straw yellow. II gathered young for cooking, no other squash approaches it in flavor, while if allowed to rip.es' on the vine they can be stored and will keep in excellent condition until late the followitg June. Either for baking like sweet potatoes or making pies during the winter the quality is unsurpassed. Oz. 15c, tb. $\$ 1.00$.

Burpee's Bush Fordhook Squash Being of "bush growth," the plants can be ruits are rather shorter and thicker than grown much more closely together. The fleshed and have a smaller seed cavity, but unfortunately do not come as true to type. Ou, Fordhook squash is ahout a week later than the Early White Bush; it is much sweeter anc. better flavored. Oz. $15 \mathrm{c}, \mathrm{Tb}$. $\$ 1.00$.

The Faxon A very desirable variety for the home garden, very productive, of medium size (five or six pounds), fine-grained, dry, sweet, a good keeper, uniforn! in shape, but varied in color. This variation in color is a distinct feature of the squash Oz. $10 \mathrm{c}$, th.. $\$ 1.00$.

Mammoth White Bush Scallop An improvement on the old variety, larger ib. $75 \mathrm{c}$.

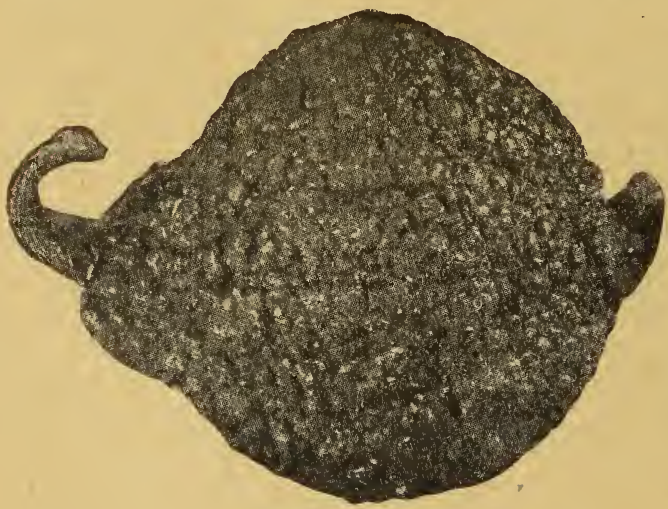

Boston Marrow This grows larger $\mathrm{th}$ a $\mathrm{n}$ deep color: skin thin, yellow, with pinkish tint; desirable for pies, not so dry as the Hubbard. Oz. $10 \mathrm{c}$, tb. $75 \mathrm{c}$.

Delicious One of the thickest meated and very best in excepting Hubbard. Although at any time excellent, does not acquire its best quality until winter Oz. $15 \mathrm{c}$, th $\$ 1.00$.

Golden Hubbard A distinct shape and general character of the Hubbard, but a little smaller, earlier to mature, and a rich orange-red instead of the dark olive-green of the old Hubbard, while the flesh, which is thirk, is a little deeper colored, of fully as good quality, fine-grained and dry. Oz. 10c, to. $\$ 1.25$.

Warted Hubbard Th is is strain of the famous Huhbard and is an ideal winter squash for marketmen. The Hubbard Squash

shell is deeply warted and a dark green in culor, the flesh dry and sweet in flavor. It grows to large size, is a fine keefer and shipper. its cooking qualities unsurpassed. Oz. $15 \mathrm{c}, \mathrm{tb} .75 \mathrm{c}$. Mammoth Chili The largest variety, attaining under special cultivation enormous

\section{SWISS CHARD}

Giant Perpetual ("Cut-and-Come- This, though a variety of Chard, is to all A ") practical purposes a giant spinach, the Again") Spinach Swiss Chard readily, with a decided spinach flavor. Its great merit is that it will supply the greens from spring until late in the fall. The large midribs can be cooked and served like asparagus. If wanted for greens cut when 6 inches high just above ground and it will grow out again. Oz. 10c, 1to. $\$ 1.00$. 


\section{SWEET HERBS}

CUL.TUR1:. - Sow in early spring, at the time when the trees begin to leaf, in ordinarily zond and well drained garden soil, in rows 12 to 24 inches apart. Cover seed lightly. Thin or transplant to stand 6 to 12 inches apart in the rows. Cultivate frequently and keep frec from weeds.

Packet

Anse, seeds a romatic..................

medicinal qualities.............5c

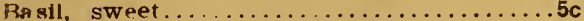

Burage. leates used for salad.............

Caraway, steds a romatic............

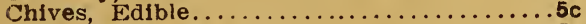

Coriander, seeds aromatic................

i)ill. seeds aromatic and medicinil........5c

Fennel Swcet, seeds aromatic............

Horehound $\ldots \ldots \ldots \ldots \ldots \ldots \ldots \ldots \ldots \ldots \ldots \ldots \ldots \ldots \ldots$

Lavender. leaves aromatir............

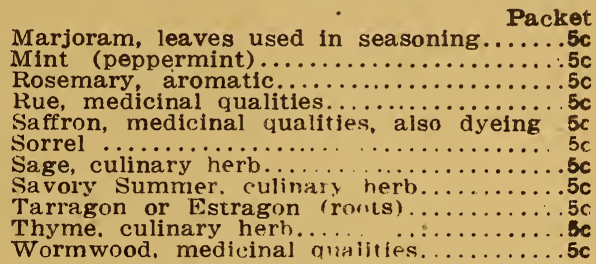

TOBACCO SEED

Havana Tobacco Seed, per oz. $75 \mathrm{c}$, per pkt. $10 \mathrm{c}$.

Liebesapfel (Gr.)

TOMATO

Pomodori (1t.)

As tomaties are lery sensitive to frost, they cannot be set in the open rield until ahrut May 1st. The seed must be sown in well protected hotbeds, sowing same about March 1st. A hardy and stocky plant is had by transplanting the small plants in the bed a few weeks before transplanting to the lield. Or when about four inches high, the top may be pinched off and the plant grows stockier.

Sow the seed broadcast, using one ounce to about three square feel if area, which will vield plants enough to set an acre. In the field set tall varieties six feet apart and dwarf varieties three feet apart. A slight trellis is advisable in the garden. A moderate amount of water should be applied at the roots at regular intervals.

Bonney's Best Early An extra early variety having great favor with the market hard core. Color wight scarlet. Fine, early, handsome, especially profitable for market gardeners' use. Oz. $35 \mathrm{c}$, th. $\$ 3.50$.

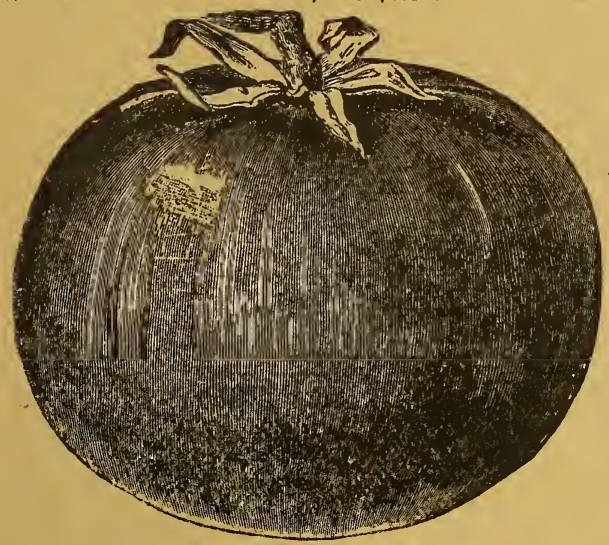

June Pink The June Pink tomat" in to the Earliana. The plant is compact. hranching freely, with fruit hanging in clusters of six to ten fruits, both in the crown and at the forks of the branches. It ripens fullv as early as the Sparks Earliana and quite ten days to two weeks ahead of Chalk's Early Jewel. Fruit of medium size, uniform, smooth, and attractively shaped, without cracks or any green core. Continues to bear and ripen fruit until frost. Oz. $35 \mathrm{c}, \pi \mathrm{t} . \$ 3.00$.

\section{Chalk's Early Jewel A wowderpul} in that it is early and bears continuously throughout the season. The fruit is large, smooth, uniform, and well ripened clear to the stem, and the flavor and quality are especially fine. Color, bright scarlet. Oz. 25c, to. $\$ 3.00$.

Earliana (Sparks) $\begin{gathered}\text { The earliest tall } \\ \text { variety. forming }\end{gathered}$ ripe fruit much earlier than any other variChalk's Early Jewel ety. The fruit is large, smooth, of a bright scarlet color, and of fine quality. Very valuable for early market use. Pkt. 10c, th. \$2.75. Beauty A rather early, tall variety; very prolific, with good-sized, smooth fruit of a

Livingston's Dwarf Stone Anis is what he says of it: ...The same sort of Oz. $25 \mathrm{c}, \mathrm{Tb}$. $\$ 2.25$. tomato as Dwarf Champion, but the vine is of stronger growth, and the fruit is of double the aize. It is equally early, is equally prolific. The shape of the frilt is perfect. It is very solid. ripens very evenly and is of excellent quality. Oz, 35c, tb. $\$ 3.00$.

Dwarf Champion A dwari variety, sometimes called the tree tomato on account of ing. Fruit medium-sized, smooth, uniform, and of a purplish to stand alone without trellisMatchless A tall-growing, prolific variety with large fruit, which is rather flattened, smooth and uniform. Color, bright scarlet. For canning and general main crop market, there is no better tomato grown. Extra selected strain. Oz, 40c, to. \$2.75.

Ponderosa An extremely large, irregular-fruited variety. Vine tall, and fruit very Oz. 40c, tb. $\$ 4.00$. solid and purplish-carmine in color. Rather coarse and of fair quality only. Red Cherry The fruit is small and globe-shaped, about one to two inches in diameter Red Cherry it is very valuable for preserving. Oz. 25c, to. $\$ 2.50$.

Red Pear Shaped As the name implies, the fruit is shaped like a pear-small at three inches long. It is bright scarlet. Oz. 25c, to. $\$ 2.50$.

Golden Oueen (Bright yellow.) Best large yellow tomato. Much like Paragon, exall respects, either for slicing in color. Always smooth and ripens early. Quility extellent in Pear-Shaped Yellow (Bright yellow.) A pretty tomato, similar to Pear-shapeo Red, except in color. Oz, 30c, to. $\$ 3.00$. 
While turnips are a favorite fall and winter vegetable, they may also be had in the sprins by proper sowings. They are of easy culture, but need well-worked, rich soll to insure quick, uninterrupted growth, when they will be tender and free from woodiness.

For fall and winter use sow the seed in August, in rows 10 to 18 inches apart, using one ounce to 250 feet of row, thinning the plants when very young to three or four inches apart. For spring use sow in January. For fleld culture sow in rows about two feet apart, usins one to three pounds of seed per acre.

Early Snowball A medium globe-shaped variety of pure white. Very soltu and of Early White Flat Dutch (Strap Leaf)

A medium-sized, flat variety; clour tine table variety. Oz. 10c, to. $75 \mathrm{c}$.

Carly White Milan Roots flat, smooth and symmetrical; pure white. Tup very Larly White Milan small, upright and compact, permitting close plantisg. 2rots terifiest and much the best of any extra-early white variety. $0 \mathrm{z}, 10 \mathrm{c}, \mathrm{tb} .75 \mathrm{c}$.

Early Purple-Top Milan Differs from the preceding in that the roots are nor F A well-known varlety and very extensively $10 \mathrm{c}, \mathrm{tb} . \$ 1.00$. Early Purple-Top Flat A well-known variety and very extensively grown. Ronts 10c, th. $60 \mathrm{c}$.

Early Purple-Top White Globe One of the handsomest varieties, the upper portion of the root being a purplish red, the a marketable size sooner than other large globular varieties. Of the best quality and an excellent keeper. Owing to its strong growth should be more severely thinned than other early varieties. We offer New England grown seed of a selected strain, which repated trials have shown to be much superior to those generally offered. Oz. $10 \mathrm{c}$, th. $60 \mathrm{c}$.

Cow Horn A long white turnip. Grows to a large size, standing half out of the ground. It is tine flavored and desirable. Cow Horn turnip sown in connection with Rape is one of the newly recommended things for green manuring purposes. Oz. 10c, to. 60c.

\section{Ruta-bagas or Swedish Turnips}

Laing's Improved Swede One of the oarliest; riety; fine for the table. Oz. $10 \mathrm{c}, \mathrm{tb}$. $60 \mathrm{c}$.

Sweet German, or Russian White, sweet, exrate keeper. Oz. $10 \mathrm{c}$, th. $60 \mathrm{c}$.

Carter's Imperial Swede This is the best of Oz. $10 \mathrm{c}$, tb. $60 \mathrm{c}$.

American Purple-Top Very hardy and productsweet; good for stock or table use. Oz. 10c, tb. 60c.

Long Island Improved Bred Prom the "Ameriwhich it is a great improvement, being nearly double the size; an immense yielder and good keeper; flesh rich yellow, of fine quality. Oz. $10 \mathrm{c}, \mathrm{Tb} .60 \mathrm{c}$.

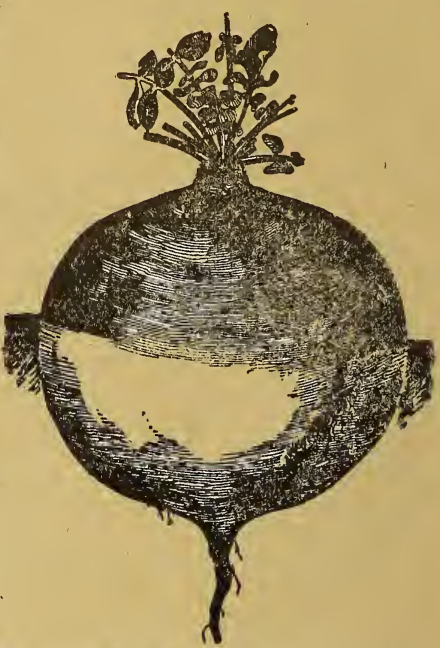

Ruta Baga American Purple Top Turnip

Names of a few gardeners who have dealt with this house continuously from 31 to 45 years:

Wm. Clark, Solvay................45 $\mathrm{yrs}$.

Charles B. Day, Skaneateles.................

J. N. Rose, Syracuse.................. “

S. B. Babcock, Fulton.................... “

Albert Wright, Syracuse, died $1915 \ldots . . .46$ “"

Michael O'Brien, Syracuse, died 1913..39 “

William Lambert, Salina................
Henry $O$ 'Neil .........................

John Butler, Onon. Valley, died $1916 \ldots 43$ "

A. H. Ballard, East Onondaga.........34 "

Geo. Craddock, Onondaga, died $1912 \ldots 43$ “.

Henry Wright, Syracuse, died $1912 \ldots . .43$ “"

Henry G. Day, Seneca Falls...........37

Also hundreds of others who have dealt with us 8 to 30 years.

Mr. F. H. Ebeling, Syracuse, N. Y.

Seneca Falls, N. Y., Dec. 18, 1916.

Dear Sir-Having purchased seeds from you since 1879 , I feel very confident in saying that your seeds are among the best that grow. For several years I have used your Iowa Gold Mine Ensilage Corn, and have had such good results that the past year I sold many bushels to my neighbors. The Alberta Cluster Oats yielded 65 bushels per acre. From 4 bushels of your Telephone Peas I picked 135 bushels marketable peas. I also have 50 acres of the best new seeding that I ever had, from your clover and timothy seed. 


\section{SELECT}

FLOWER

SEEDS.

Abobra (Gourds) Beautiful variety of olimbing gourd with elegant foliage. 5c pkt.

Abromia (Sand Verbena) Tralling, annual, sweet-scented clusters like verbena, lasting in bloow a long time; for rock-work or hanging-baskets. Height 12 inches. 5c pkt.

Abutilon (Ćhinese bell flower or flowering maple) Free flowering, perennial shrub; flne for un: doors. For outdoor $\mathrm{sc}$ before April. Will bloom first season. 10c pkt.

Acacia Half hardy shrub having ornamental foliage, beautiful shades of yellow, globula flowers. Soak seed in warm water before sowing. Height 6 to $10 \mathrm{ft}$. Mixed 10c pkt.

Acomitum (Monk's hood or Wolfs bane) Hardy, perennial, long spikes of odd shape blue an white flowers, adapted to shady corners or among shrubbery; 3 to $5 \mathrm{ft}$. 50 pkt.

Lcroclimium Pretty, annual everlasting, 15 inches high, lovely white or rosy pink flowers flne for border. Sgl. or dbl. $50 \mathrm{pkt}$.

alumia Hardy white perennial, 2ft. high, pure white double flowers, bloom from spring unti: frost, flne for cemetery decoration. Flowers first season if sown early.

Adlumia (Mountain fringe or Allegheny Vine) A hardy biennial e'imber, will resow itself yea after year, feathery foliage resembling Maiden-hair Fern, flowers tube-shaped, flesh colored completely covering the plant, fine for trellises, stumps, etc. $100 \mathrm{pkt}$.

Adomis (Pheasant's eye) Flos Ádonis, Showy, hardy, annual, of easy culture, flne cut foliage, blooms a long time; dark orimson flower with light center. Height $1 \mathrm{ft}$. 50 pkt.

Ageratum (Floss Flower) Fine bedding sort, literally a sheot of bloom from early summer ur: til frost; not liable to be spoiled by rain, flowers not liable to fade; easily raised from seed Sow in March or in hot-bed and transfer into open ground in June when weather is suitable valuable for winter flowering for conservatory. $5 \mathrm{c} \mathrm{pkt}$

Blace Perfection Dark blue, largest flowering, fine bedder. $100 \mathrm{pkt}$

Cope's Pet Azure blue, flne light blue sort for edging, 100 pkt.

Dwarf Princess Pauline Beautiful, compact, sky blue, white center, very exquisite. 100 pkt.

Mexicanum Lavender blue, $11-2 \mathrm{ft}$. $50 \mathrm{pkt}$.

Imperial Dwarf White Height 8 inches. $5 \mathrm{c} \mathrm{pkt.}$

Arrostemma (Rose of Heaven) Free blooming, hardy, perennial, blooming first season, helgh 1 to $2 \mathrm{ft}$. Mixed 50 pkt.

Alyssum (Mad-wort) Pretty little plants for beds, vases, baskets, edging, etc. Bloom profusely all summer, also useful for winter. Very sweet-scented.

Eittle Gem (or Carpet of Snow) 4 to 6 inches in height, each plant covering a circle of 15 to 30 inches. $5 \mathrm{c} \mathrm{pkt.}$

Sweet Alyssum Trailing flowers, white. 50 pkt.

Tom Thumb Compact, dwarf, fine for edging, white. $5 \mathrm{c} \mathrm{pkt.} \mathrm{30c} \mathrm{oz.}$

Saxatile Compactum (Basket of Gold,) handsome yellow flowers, hardy perennial, bloomin first season, fine for rock work, $1 \mathrm{ft}$. $5 \mathrm{c} \mathrm{pkt.} 30 \mathrm{c} \mathrm{oz}$.

Amaranthus Brilliant foliaged annuals, 3 to $5 \mathrm{ft}$. Useful in borders or centers of large bedis. Do not plant too closels.

Brrilliant Foliage bright red, ends of branches carmine-rose, red and yellow. 10c pkt.

Caudatus (Love lies Bleeding) Blood red, drooping follage, $3 \mathrm{ft}$. $5 \mathrm{~s}$ pkt.

Salicifolius (Fountain Plant) Pyramidal, drooping habit. 5c pkt.

Sum rise Bronzy Crimson to brilliant scarlet. Fine for parks and large beds, 3ft. 10e pkt.

Sulphurime Leaves dark green, bright sulphur yellow. 100 pkt.

Trricolor' (Joseph's Coat) Leaves red, yellow and green, $3 \mathrm{ft}$. $5 \mathrm{c}$ pkt. $30 \mathrm{c} \mathrm{oz}$.

Ammobium (Winged Everlasting) Grandiflorium, Pretty Border, annual ever-lasting, flower white with yellow diso. 5c pkt.

Ampelopsis (Boston or Japanese Ivy) Hardy, perennial climber, olive green leaves turning te scarlet in fall. Popular climber, flne for brick or stone walls. 10c pkt.

Anemome (Windflower) Hardy, perennial, large flowers, flne for bouquets. Mixed colors. $10 \mathrm{c} \mathrm{pkt}$.

Antirrhinum (Snap Dragon) White, yellow, scarlet, each 10c pkt. mixed colors. $10 \mathrm{c}$ pkt.

Aquilegia (Columbine) Charming, hardy, perennial, 1 to $3 \mathrm{ft}$., profuse bloomer, blue, white $\theta_{8}$ rose, yellow, purple, striped, etc. 'Fine for borders. Sgl. mixed 50 pkt. Dbl. mixed $5 \mathrm{c}$ pkt.

Arabis (Rock Cress) Alpina very early, pure white, spring flower, appear as soon as snow dis. appears. Fine for rockeries or edging. 6 inches high. $10 \mathrm{c} \mathrm{pkt.}$

Arctotis Grandis, Beautiful new annual, 2 to $3 \mathrm{ft}$. high, large strong pure white flower embel lished with yellow center, of the easiest culture. $10 \mathrm{c} \mathrm{pkt}$.

Axistolochia Sipho (Dutchman's Pipe) A quick growing climber with large heart shaper leaves. $5 \mathrm{c}$ pkt.

Armeria (Sea pink or cushion pink) Very pretty edging plant, bearing large tufts with rosy pin flowers, hardy perennial. 10c pkt.

Asparagus Plumosus Nanus Graceful climber, flner than most delicate ferns. Will last for weeks after being cut, easily cultivated. $25 \mathrm{c}$ pkt.

Sprengeri One of the best for hanging baskets or general purposes, fronds $4 \mathrm{ft}$. long. 10c pkr

Verticillatus Graceful, hardy perennial climber, scarlet berries. $10 \mathrm{c} \mathrm{pkt.}$

Asperula Ddorata (Sweet Woodruff) Fragrant leaves and stems, grown in shaded placos white flowers. $5 \mathrm{c} \mathrm{pkt}$.

Aster's are now one of the most important summer and autumn flowers. Their immense popu. larity and world-wide demand shows their adaptibility to any soil or climate, there being early medium and late flowering sort which extends the blooming period from early July until frost. For the best results the ground should be very rich. Good results can be obtained from ordi. nary garden soil.

Aranching Varieties $11-2 \mathrm{ft}$. high., very double, beautifully inourved. Orimson $10 \mathrm{c}$, blev $10 \mathrm{c}$, pink 10c, white $10 \mathrm{c}$, rose $10 \mathrm{c}$, mixed $10 \mathrm{c}$. 
Asters (Continued).

Branching Paeony Flowered In vigor of growth, size or bloom and other qualities this type is unequalled. Height about 18 inches, free branohing habit with long stems. Orins son 10c, blue 10c, white 10c. mixed 10c.

Comet Beautiful with long curled petals resembling the Japanese Chrysanthemum, height 15 inches. Carmine $10 \mathrm{c}$, pink $10 \mathrm{c}$, blue $10 \mathrm{c}$, mixed $10 \mathrm{c}$.

Giant Comet Similar to the above but of stronger growth, 18 to 24 inches high. Pure whit $10 \mathrm{c}$, white and rose $10 \mathrm{c}$.

Giamt Bramching Comet Very strong growth, 18 inches high, branching habit, flower of large size on long stems. $10 \mathrm{cpkt}$.

Queen of the Market The earliest flowering Aster, blooms three weeks in advance of the general run, flowers good size on long stems. Fine for cutting. Crimson $10 \mathrm{c}$, pink $10 \mathrm{c}$, purple $10 \mathrm{c}$, white $10 \mathrm{c}$, mixed 10c.

Victoria Magnificent bedding or cutting variety, flowers large beautifully imbricated, 1 1-2 high. Scarlet $10 \mathrm{c}$, purple $10 \mathrm{c}$, blue $10 \mathrm{c}$, pink $10 \mathrm{c}$, white $10 \mathrm{c}$.

China Mixed Very flne, all colors $5 \mathrm{c}$.

Quilled Aster Double or quilled petals, flne for bouquets. 2 it. 5c pkt.

Crowm or Cocardeau Very showy, double white center, mixed colork: 11-2 ft. high $10 \mathrm{cpk}$

Daybreak Grand variety of symetrical growth and habit. 18 inches high, globe shaped double, delicate, pink tint. $15 \mathrm{c}$ pkt.

Dwarf Chrysanthemum Large flowering, dwarf, double, excellent for plants and pote Mixed 100 pkt.

Fire-IBail Magniflcent, double, brilliant, deep scarlet 10c.

Iapanese or Tassel Entirely distinot, new pyramidel shape, 18 inches high, long stems flowers five inches across, wavy twisted, needle shaped petals, very graceful. Mixed $10 \mathrm{c}$ pt.

Ostrich Feather Magnifloent, resembling the Comet, flowers of immense size of loosels formed petals, equaling the best Japanese Chrysanthemums. White or pink 15e each.

Rose flowered Large double, pyramidel, height $2 \mathrm{ft}$. Mixed colors $10 \mathrm{c}$.

Snow IBall A beautiful distinct sort, short petals, pure white $10 \mathrm{c}$.

Washington Splendid, very large, double, diameter 6 inches. White $15 c$.

Peremmial Single, hardy. Does well in any garden soll. If sown early will flower in eariy seasnn. $10 \mathrm{c}$ pkt.

Bachelor's Huttons (See Globe Amaranth).

Balloom Vine (Love-in-a-Pufi) Rapid growing annual climber, white flowers, seed vessels look like miniature balloons. 5c pkt.

Aalsams (Lady Slipper) Double, camellia flowered type, and old favorite, gorgeous brillian colored, double flowers in great profusion, easily cultivated, $2 \mathrm{ft}$. high.

Primce Bismarck Salmon, pink, double.100 pkt. Scarlet, yellow, violet and mixed each 50 White 10c.

Eaptisia (False Indigo) Beautiful, hardy, perennial, pea-shaped flowers on spikes 6 inchez long, bright blue $21-2 \mathrm{ft}$. $5 \mathrm{c}$ pkt.

Bartonia Showy yellow flowers, very brilliant, cannot be transplanted. 5c pkt.

Begomias Fine bedding variety, equal to geraniums, sturdy growth, $1 \mathrm{ft}$. high, forming dens bushes completely covered with flowers from May until frost. Unequalled as pot-plants for winter flowering and will remain in bloom the entire year. Easily raised from seed. Doubls mixed 25c, single mixed 150.

Tuberous Rooted Begonias Plants of great value for summer decoration or windok gardening, bloom first season from seed if sown in February, transplanted as soon as weathe? permits, produce flowers the entire summer. Double mixed 25c, single mixed $25 \mathrm{c}$.

(1)mamental Leaved Begonias Beautiful, varigated foliage. Mixed 25c.

Bellis Double Daisy, very handsome spring-flowering plant. 5 pkt.

Brachycome (or Swan River Daisy) Dwarf, annual, profuse bloomer, pretty blue or whitue flowers. 50 pkt.

Calceolaria (Lady's Slipper) Ornamental plant with mass of beantiful pocket-like flowers, bloom early and very fine for decorating green-house or conservatory.

irborida Grandifitora, 20 inches high Mixed, 25c.

Tigrina Large tiger spotted brilliant colors 25c.

Calondula (Pot Marigold) Very showy, free-flowering until frost, hardy annual, grow in any good soll, fine for beds or mixed borders, fine for pot culture, height 1 it.

Meteor Large double yellow, striped with orange 5c.

Drange $K$ ing Large double orange red flowers $5 c$

Pure Gold Fine Golden Yellow 5o.

Mixed per pkt. 5c.

Pluvialis (Cape Marigold) White daisy-like flowers, under side of petals lilac, 5c.

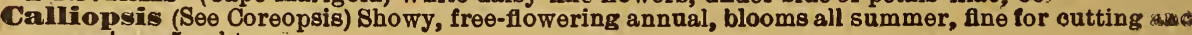
massing. $50 \mathrm{pkt}$.

Coromata Large yellow, fine for bedding $5 \mathrm{c}$.

Cidden Wave (Drummondii) Large golden yellow with brown center, fine for borders. se.

Timctoria Golden with garnet eye $5 \mathrm{c}$.

Nigra Speciosa Crimson 5c.

Campamula (Bellflower) Favorite, hardy herbaceous with great profusion of bell flowers, thrives in light rich soil.

Carpatica Blue and white mixed, bloom the whole season, 6 inches $5 c$.

Persicifolia Grandiflora Fine hardy bell flowers 2 to $3 \mathrm{ft}$. blue or white. Mixed 10c.

Camary-Fird Vine (Tropæolum Canariense) Handsome annual, rapid olimber, charming little canary-colored blossoms bearing a fancied resemblence to a bird with wings half expanded 5s.

Candytuft (Iberis) A great favorite, fine for outting, looks best in beds or masses. Bow 10 spring, will bloom until frost, very hardy, easily cultivated. Single plants look well and bloon profusely, 1 it.

Carmine bo.

White 5e. 
Crandytufi (Continued)

Crimson 5c.

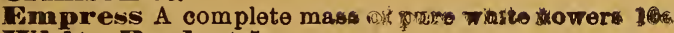

White Rocket $5 \mathrm{c}$.

Lavender $5 \mathrm{c}$.

Mixed colors $5 \mathrm{c}$.

Peremmial mixed 10c.

Camma (Indian Shot) Without exception on $\theta$ of the handsomest bedding plants. Soak the seede in warm water until they show evidence of swelling. When the second leaf is out pot singly and keep under glass until proper season for planting out. Mixed colors 10c.

aanterbury Hell (Campanula Media) Sgl. mixed 5c. Dbl. mixed 5c.

Cup and Sumcer (Calycanthema) Fine white, blue and rose, resembling cup and saucer. 5c

Carnation (See Dianthus) Great favorite for their delicious fragrance and richness of color indespensible for winter or summer culture. Dbl. mixed. $10 \mathrm{c}$.

Marguerite Carmations Very popular, as they begin flowering a few weeks from time of sowing, half-dwarf, strong, requiring no support, produce long, strong stems, abundant large double, beautifully fringed, highly-scented flowers.

Mixed color's $10 \mathrm{c}$.

Castor Oil Beam (See Ricinus).

Celosia or Cristata or Cockscomb Varieties Free-blooming annuals, plant in light soil not too rich, grand for border and fine for pots.

Empress Combs of Colossal size, known to measure 45 inches from tip to tip; rich crimson 10 c

Glasgow Prize Dark Crimson 10c.

iDarif 8 in ches high, sometimes measure $2 \mathrm{ft}$. across $10 \mathrm{c}$.

Mixed Dwart" $5 \mathrm{c}$.

Centaurea Under this name is included the popular annuals like Corn Flower, Blue Bottle Ragged Sailor, Sweet Sultans, etc. Grent favorites, flne for cut flowers; white-leaved sorts, or 'Dusty Millers are largely used for bedding, vases, etc.

Sweet Sultams (Centaurea Imperialis) Beautiful, sweet-scented, strong stems, when cut wil) stand for several days in good condition of easy culture. Mixed colors 10c. Named colors $10 \mathrm{c}$

Giant Sweet Sultams (Centaurea Oderata) or Giant Cornflowers, easy to cultivate flowers 2 to 4 inches in diameter, very graceful, sweet-scented.

Chameleon Pale yellow turning to a beautiful rose $10 \mathrm{c}$.

Dderana Reddish lavender, very fragrant 10c.

Mararaitae White 10c.

Cheiramthus (See Wall Flower) Mixed $5 \mathrm{c}$ pkt.

Chrysanthemums Annual sorts, showy, effective garden favorites. Dbl. mixed 10e pkt. sgl. mixed 10c pkt.

vimeraria Seed may be sown from May to September in succession. Where only one sowing is made July should be preferred. Cinerarias grow so freely that the seedling may go straight from seed-pans to thumb-pots. For transplanting, plant in a cold frame facing north, if possible. When pots become full of roots shift into larger ones until the flowering size is reached.

Dwaref Mixed 25c per pkt.

Tall Mixed 25c per pkt.

Double Flowering $25 \mathrm{c}$ per pkt.

Stellata (Star Cineraria) A charming variety with large spreading panicles of starry flowers Same colors as the common Cineraria. The grace and elegance of the plant and flowers make them very effective for house or conservatory decoration; especially flne for church decoration. and very useful for cutting. 35c.

Cineraria (White Leaved Sorts)

Dusty Millex Fine for bedding and margins, valued for their beautiful, downy, silvery foliage, half hardy perennial ; $2 \mathrm{ft}$.

Maritima Candidissima Silvery foliage $5 \mathrm{c} \mathrm{pkt.}$

Acanthifolia Silvery foliage $10 \mathrm{c}$ pkt.

Clematis Rapid.growing climber, flne for arbors and verandas. Seeds are slow to germinate, and should be soaked in warm water 24 hours; hardy perennial mixed colors. 10c pkt.

Clianthus (Australian Glnry P $\Theta a$ ) Beautiful, tender, perennial shrub with clusters of brilliant pea-shaped flowers, 3 inches in length, with large black blotch for center. 10c pkt.

Cobaea (Cups and Saucers Vine) A rapid climber. fine for trellises, arbors, etc., clings to $a n$ rough surface. Place seeds in the ground edgewise and cover with light soil.

Purple 10c pkt. pure white. 10c pkt.

Coccinea Indica (Scarlet-fruited Ivy-leaved Climber) Handsume, annual, gourd species with beautiful glossy ivy-like leaves, contrasting with the flne snow white bell-shaped flowers and bright carmine fruit. $10 \mathrm{c}$ pkt.

Coleus (Flame Nettle) An attractive foliage plant for house or garden, very interesting to grow from seed, easily raised; sow in March or April. 10c pkt.

Comvolvulus (Morning glory) Climbing varieties, very popular and one of the most freeflowerıng, rapid-growing plants in cultivation; doing well in almost any situation, with beautiful brilliant flowers; annuals, $15 \mathrm{ft}$. Mixed colors $15 \mathrm{coz}$. $5 \mathrm{c}$ pkt. Dwarf per oz. 15c. $5 \mathrm{c}$ pkt:

Coreopsis. (Søe Calliopsis) A very flne hardy plant with large, showy bright, yellow flowers, pro duced in great abundance from June until frost, especially flne for cut flowers having long stems and lasting in good condition a week or more. These grow from seed, flowering the flrst year if sown early. $5 \mathrm{c}$ pkt.

Cosmos Beautiful autumn-blooming plant, producing thousands of beautiful flowers in pure white, pink and crimson shades; flne for autumn decoration when other flowers are scarce. Sow in spring in open ground when danger of frost is over, or may be started under cover and transplanted. Set about 18 inches apart in rows or in masses in beds. When about a ft. higb pinch the tops out to induce a bushy growth., $21-2$ to $4 \mathrm{ft}$. in height.

Crimson, 5c.

Pink 5c.

White bo. 
Cosmos (Continued)

Mixed $5 \mathrm{c}$ pkt.

Dware $5 \mathrm{c}$ pkt.

Cucurbita (See Ornamental Gourd)

Cyclamen Charming plant with richly colored follage, fragrent lowers. Creat tavorites winter or spring. Sow in spring or autumn.

Persicum Choicest mixed. 15c pkt.

Pure white, dark red, rose $\theta$ ach $25 \mathrm{c}$ pkt.

Cyperus (Umbrella Plant)

Aiterdifolius Excellent for growing in water or damp places. Very ornamental nous plant. 10c.

Cypress Vime (Ipomaea Quamoclit) A favorite summer olimbing annual, with feathery foliags and star-shaped flowers borne in clusters.

White $5 \mathrm{c}$ pkt.

Scarlet $5 \mathrm{c}$ pkt.

Rose $5 \mathrm{c}$ pkt.

Mixed colors $5 \mathrm{c}$ pkt.

Dahlia One of the best late summer and autumn flowering sorts, very popular. The doubls sorts will bloom first season if sown early. Single will bloom first season if sown in the oper. ground. Many prefer the single sorts to Cosmos, having the larger variety of colors and longes season of bloom.

Double, finest mixed 10c.

Single, flnest mixed 10c.

Single Tom Thumb, dwarf. $1 \mathrm{ft}$. 10c.

Datura (Trumpet Flower) Ornamental annuals, large showy flowers; 2 to $3 \mathrm{ft}$. Dbl. and $\mathrm{s}^{\text {th }}$ $10 \mathrm{c}$ pkt.

Delphinium (Perennial Larkspur) One of the handsomest hardy perennials, splendid flower and curiously cut leaves; for permanent beds and borders they are indispensable.

Zalil (Hardy Yellow Larkspur) Produces very long spikes of 40 to 50 sulphur yellow blossomis each 1 inch in diameter; flowers from June to August, plant thrifty and bushy; 3 to $4 \mathrm{ft}$. $10 \mathrm{c} \mathrm{pr}$.

Eormosum Popular for groups, tall spikes of dark blue flowers with white oyes; 2 to fit. $5 \mathrm{c} \mathrm{pkt.}$

Nudicaule Large scarlet flower; 1 1-2 ft. 10c pkt. Mixed flnest single 5c pkt. mized 10c pkt.

Dianthus or Pinks A magniflcent sort embracing some of the most popular flowers cultivation, of great variety and brillancy with profusion of bloom. The sorts classed as annuaks fmay be sown out-of-doors when danger of frost is past. In a few weeks time they are 2 mase of bloom continuing until frost; $1 \mathrm{ft}$.

Double Ammuals

Chimensis F1. P1. (China or Indian Pink). Mixed colors 10c.

Heddewigi irl. Pl. (Japan Pink) Double mixed 10c.

Snowball Double white, fringed, very fine $5 \mathrm{c}$ pkt.

Imperial Fl. Pl. (Double Imperial Pink) Mixed 10c.

Salmon King A double flowering variety, flnely fringed flowers of a brilliant salmon coicr 10 changing as they fade to a salmony-rose; charming for beds or borders. $10 \mathrm{c} \mathrm{pkt}$.

Single Anmuals All single sorts have large flowers 2 to 4 inches in diameter, flne for beres or borders; $1 \mathrm{ft}$. high.

Heddewigi Noloilis (Royal Pink) Beautifully fringed, colors run from white to dark red 10

Tilledewigi (Japan Pink) 10c.

Laciniatus Fl. Pl. (Double Fringed Pink) Large, duuble, showy flowers, with fringe? edges and beautifully striped; mixed various colors. 5c.

Hardy Garden Pinks The varieties are well adapted for beds and borders; delightful, tre freshing, spioy odor, should be in every garden where cut flowers are wanted.

Semperfforens (Ever-blooming hardy garden Pinks) Very beautiful, sweet-scented, doubic semi-double and single in great diversity of colors, mixed colors. $25 \mathrm{c}$.

Dianthus (See Carnation) Carnations are general favorites for their delicious fragrance anct richness of colors. They are indespensable for the green-house in winter and the garden is summer. The Marguerite is one of the best for summer flowering.

Fine Double Mixed. The best for garden culture $10 \mathrm{c} \mathrm{pkt.}$

Marguerite These are the most popular of caranations with the amateur, as they begin flow ering within a few weeks from the time of sowing. Our strain is of semi-dwarf, robust habit requiring no artiffeial support, and produces on long strong stems an abundance of large double, beautiful fringed, highly scented flowers. Separate colors 10c. Mixed, all oolors. Marguerite Carnation 10c.

Didiscus Very pretty annual, blooms profusely from July to November, pale lavender blossonxsis excellent for cutting. 15c pkt.

Digitalis (Foxglore) Handsome ornamental hardy perennial plant, easilv grown, flne tor shrubberies; 3 ft. Mixed colors, 10c pkt.

Dolichos (Hyacinth Bean) Rapid annual climber with large clusters of handsome flowers prow ducing later in place of flowers, pods of a deep purple, very ornamental, mixed colors. $10 \mathrm{c}$ pkt.

Dracgema (Dragon Plant) Fine ornamental leaved plant. Mixed colors. 25c pkt.

Echimocystis (Wild Cucumber Vine) Quickest growing vine known, fine for covering trellises, fences, etc. $5 \mathrm{c}$ pkt.

English Daisy (Bellis Perennis) A favorite almost hardy perennial blooms from early spring until late in summer, easily raised from seed, 4 inohes high. Dbl. mixed, flnest quality 10c. Red, white or pink 10c.

Brigeron (Flea-bane) An attractive, asterlike flower, 1 inch across, purplish-rose with goldex center, hardy perennial, blooms first year from May until frost if sown early. 20c pkt.

Erymgium (Sea Holly) Handsome ornamertal, hardy plant 2 to $3 \mathrm{ft}$. high. Fine for drylue for winter bouquets. $15 \mathrm{e}$ pkt.

Esschscholtzia (California P.oppy) Fine annual for beds, bonder or masses, bloom nntill tros $1 \mathrm{ft}$. Sgl. mired $50 \mathrm{pkt}$. dbl mired $60 \mathrm{pkt}$. 
Euphorbia Strong, tall.growing annuai, attractive foliage, 100 pkt.

Forret-me-nut (See Myosotis) 5c.

Four o'elock or Miribilis 5c.

Fox Glove (See Digitalis)

Mchsia (Lady's Eurdrops) Well-known sort of easy culture, for house or garden, mixed co10rt $25 \mathrm{c}$ pkt.

Wailaiedia (Blanket Flower) Splendid showy annual, remarkable for profusion, size ane brilliancy of flower, bloom until frost, fine for beds, borders or cutting; 1 1-2 ft. Mixed colorg annuals $10 \mathrm{c}$ pkt. Mixed colors, perennials, $5 \mathrm{c}$ pkt.

tieraniam (Pelargonium) Double mixed, fine color 30c pkt.

Alobe Amaramth (Gomphrena) Known as Bachelor's Buttons. fine bedding plant, flower: can be dried and be used in winter bouquets; $2 \mathrm{ft}$. mixed colors. $10 \mathrm{c}$ pkt.

6oximia A superb greenhouse sort with magnificent rich colored flowers; do best in equal mixture of peat, loam and sand, mixed colors. $25 \mathrm{c}$ pkt.

(7) odetia An attractive, hardy annual, profuse, showy flowers of varied colors; 1 1-2 ft. Mix 80 colors. 10c pkt.

courds Ormamental (Cucurbita) Rapid-growing, annual elimbers, ornamental foliage; 15 to $20 \mathrm{ft}$. Mixed colors. $5 \mathrm{c}$ pkt.

*xirasses, Ormamemtal These serve the double purpose of rendering mixed flower-beds or borders attractive in summer and for use in a dried state in winter bouquets, for large beds groups on lawns, nothing gives a finer effect; largely used in public parks.

Arundo Domax (Great Reed) Hardy perennial. 10c.

Briza Maxima Fine for grass bouquets. 5e.

Bromus Brizaeformis Graceful, drooping perennial. 5c.

Coix Lachrymas (Job's Tears) Broad, cornlike leaves, annual. 50.

Erianthus Ravenmae (Hardy Pampas) Beautiful perennial. 5c

Gymerium Arontenm (Pampas Grass) Perennial, blooms the second season. $10 \mathrm{c}$

Siipa Pennata (Feather Grass) Perennial, beautiful white, delicate begins to bloom the second season; $2 \mathrm{ft}$. $5 \mathrm{c}$.

(ùy psophila Pretty, free-flowering plant for rock work, edging, etc. Mixed colors. 5c pki

Heliahthus (Søe Sunflower)

Helichrysum (Straw Flower) Fine, everlasting double flowers, flne for display; hardy annuars $2 \mathrm{ft}$. Mixed colors. $5 \mathrm{c}$.

Aleliotrope (Cherry Pie) Half-hardy perennial, flowering the whole season, very fragran Can also be trained as a greenhouse climber. Mixed colors. 10c.

Aulbiscus (Marshmallow) Showy, perennial plant with large beautiful colored flowers; 1 1-2 \% Mixed colors. 10c.

Tollyhocks One of the most majestic of hardy plants, so well known that it needs no furtiar description.

In separate colors. 10c.

Choice single mixed colors. 10c.

Choica double mixed. 10c.

Plomesty (Moonwort Satin Flower) Hardy blennial, with silvery seed pouches, very attractive $2 \mathrm{ft}$. $10 \mathrm{c}$.

Tumulus (Japanese Hop) Ornamental, fast-growing climber resembling the common hop. $10 \mathrm{c}$

mpatiens (Sultans or Zanzibar Balsam) Charming plant for decorating greenhouse or dinne? table, producing bright, waxy looking flowers. Mixed colors. 25c.

hpomoea Climbers of very rapid growth, beautiful, varied flowers; for covering walls, arbors stumps, etc.

Coccinea (Star Ipomæa) Small scarlet flowers 5c.

Boma Nox (Evening Glory) Violet, large fragrant flowers, expanding in the evening. 5c.

Rubra Coerulea (Heavenly Blue) Bright sky blue. 10c.

Aramdiflora (Moon Flower) Blooms at night and on dull days, pure white flowers, 5 to inches in diameter, rapid climber, 100.

Wob's Tears (Coix Lachrymae)

Denilvorth IV. (See Linaria)

Tochla Tricophylla or Burming Bash 10c pkt

Tady slipper (8ee Culceolaria)

Hantama One of the most desirable half-haray perennials, constantly in bloom, verbena-kite heads of orange, white, rose and other colors; 2 to $5 \mathrm{ft}$. Mixed colors $10 \mathrm{c}$.

Imperial. Tapanese This variety without question the handsomest of all Morning Glorios. Sow in guod soil as soon as weather permit, a strong vigorous elimber, flowers of gigantie size, remain open most of the day. The colorings are beyond description. Choice mixture 100

Terke (See Delphinium) One of the best known garden flowers, hardy annuals

Dwart IRocket $1 \mathrm{ft}$. Mixed colors 10c. Dbl. mixed 10c.

Double Stock Flowered Tall branching sort; $2 \mathrm{ft}$. $5 \mathrm{c}$

cathyrus (Everlasting or Hardy Sweet Pea) Free-flowering hardy perennial climber continualiy in bloom. Mixed colors. $5 \mathrm{c}$ pkt.

irender (Lavandulit Vera) Well-known, sweet-scented, hardy perennial; $3 \mathrm{ft} .5 \mathrm{c}$ pkt.

naria (Kenilworth Ivy) Charming small, hardy perennial, trailing plant. 10e pkt.

hinum (Scarlet Flax) A very showy bedding plant, brilliant scarlet, excellent bloomer, harò perennial; $1 \mathrm{ft}$. $5 \mathrm{c}$ pkt.

Cobelia (Cardinal Flower) Popular flowering plant for pots, hanging baskets, etc. Bloom pro fusely from June to November, hardy perennial.

Crystal Palace Rich deep blue. 10c pkt.

Crimsom. white or blue $10 \mathrm{c} \mathrm{pkt.} \mathrm{Mixed} \mathrm{colors} 5 \mathrm{c}$ pkt.

Hardy Perenmial Lobelias (Cardinal Flower) Brilliant scarlet; 3ft. 10c pkt.

ohospermm m. Beautiful climbing plant, trumpet shaped flower, $10 \mathrm{ft}$. $10 \mathrm{c}$ pkt.

dapimus Ornamental free-flowering annual, various colored, pea-shaped flowers; $2 \mathrm{ft}$. $5 \mathrm{c} \mathrm{pk}$

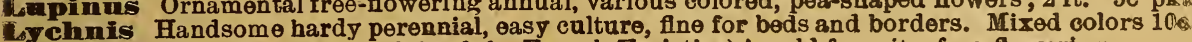
tramigold (See Tagetes also Calendula. French Varieties) An old favorite, freo-flowering

Davile Iellow $10 \mathrm{ckt}$ 
Sharigold (Oontinued)

single Tellow $100 \mathrm{plt}$.

Mixed colors $50 \mathrm{pkt}$.

African varieties

Double.yellow $10 \mathrm{c}$ pt.

Large Afiricam Yail, doublo jollow; $2 \mathrm{ft}$. 50 pkt.

Signata Pumila A dwarf, compact, bushy annual marigold with beantiful delloato fern-hte: leaves, densely covered with flowers of bright yellow striped brown; fine border plent. 50 pkth

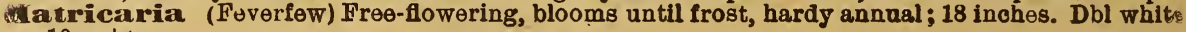
$10 \mathrm{c} \mathrm{pkt}$.

Taurandia Beautiful, slender-growing Climber, half-hardy perennial; $10 \mathrm{ft}$. Mxd colors $10 \mathrm{c}$

Mesembryanthemum (Ice Plant) Dwarf trailing plant of great beauty, blooming the whobt summer, half-hardy annual; 6 inches. $5 \mathrm{c} \mathrm{pkt.}$

Lignomette (Reseda) A popular favorite, sown in April and again in July, will keep up succession of bloom until frost; also suitable for pots, very fragrant, (orange) 50 pkt.

Gollen Machet $10 \mathrm{c}$.

Miles Spiral spike; 8 to 10 inches long, very fragrant. $5 \mathrm{c}$.

improved red $5 \mathrm{c}$.

White Very fragrant. 5c.

Sweet scented Old popular variety, small spikes, very fragrant. 5c.

Limosa (Sensitive Plant) A curious, intere ting annual with pinkish-white flowers, seaves dow and droop when touched or shaken. $5 \mathrm{c} \mathrm{pkt.}$

Mimulus (Musk Plant) Very showy, profuse-flowering plant, half-hardy perennial, blooms fir year if sown early; $1 \mathrm{ft}$. $5 \mathrm{c}$ pkt.

Tigrinus (Monkey Flower) Spotted variety. 5c.

Moschatus (Musk Plant) Fine for hanging baskets, small yellow flowers, fragrant foliage. b

Palustris The true for get-me-not, beautiful blue flower; 6 inches. $10 \mathrm{c}$.

Iiribilis (Seө Four o'clock) 5c pkt.

Momordica Very curious climber, ornamental foliage, fruit golden yellow, opens when ripe showing the seed and its beautiful carmine interior, fne for rock-work, etc., annual $10 \mathrm{ft}$. 5e. Morming Glory (See Convulvulus)

Musa Emsete (Abyssinian Banana) A splendid plant for open ground, producing a most strik ing effect when planted singly or in groups, thrives best in hot seasons, growing very large 10 to $20 \mathrm{ft}$, especially when treely supplied with liquid manure. Seeds germinate easily if start ed in hot bed; tender perennial. $25 \mathrm{c}$.

Nusk Plant (Seo Mimulus)

Mjosotis (For get-me-not) A pretty, small, double, aster-like flower, half-hardy perennial, blooms flrst year if sown early, bright blue; 6 inches. $5 \mathrm{c}$.

vastartiums (Tropaeolum) For ease of culture, duration of bloom, brillancy of color and gen. eral all around purposes nothing excels this popular variety. Plant in moderately good soil wei drained, sunny position, quick growing and bloom profusely until hard frost comes. Tall Climb ingSurts. Crimson $5 \mathrm{c}$, lilac $5 \mathrm{c}$, yellow $5 \mathrm{c}$, white $5 \mathrm{c}$, purple $5 \mathrm{c}$, rose $5 \mathrm{c}$, mixed $5 \mathrm{c}$.

cobb's Climbins Nasturtiums Scarlet, white, red. 5c each.

Tom Thumb No collection of flowers should be without Nasturtiums, they grow so freeiy and afford such a variety of rich bright colors. As a cut flower there is nothing more effective: sweet-scented and pleasing in every way.

Tall Varieties mixed. $10 \mathrm{c} \mathrm{oz}$. $5 \mathrm{c}$ pkt.

Dwar Varieties mixed. 15c oz. $5 \mathrm{c}$ pkt.

Our mixture of Nasturtiums is the flnest in the country.

asturtium ID ware Aurord, very fine $5 \mathrm{c}$ pkt,

" " Beauty, yellow and scarlet, 5c pkt

" $\quad$ "* Bronze, 5e pkt.

"* Cardinal (Dark scarlet) $5 \mathrm{c} \mathrm{pkt.}$

" $\quad$ Cloth of Gold (Light foliage) $5 \mathrm{c} \mathrm{pkt}$

" " Crystal Palace dwarf, 5c pkt.

3o $\quad$ Empress of India (Dark leaves) $5 \mathrm{c} \mathrm{pkt}$

si se King of Tom Thumb, 5c pkt.

King Theodore, very dark, 5c. pkt.

" " Ruby King, 5c. pkt.

" "F Flammulum, Grandiflorium, tall. Scarlet and yellow, extra fine, 5c pke.

Nicotiama (Tobacco Plant) Delightful, sweet-scented, pure white tubular flower, blooming con tinuously; aninual; 2 to $3 \mathrm{ft}$. $5 \mathrm{c}$ pkt.

vigella (Love in a Mist, or Devil in the Bush) A compact, free-flowering plant with curiou looking flowers and seed-pods; of easy culture; hardy annual; blue and white mixed; $1 \mathrm{ft}$. $5 \mathrm{c} \mathrm{pk}$ ?

Ormamental Grasses (Seo Grasses)

Pemsies Are so well known that no description is necessary. Sow early and transplant. Ous pansies are imported direct from the grower and are equal to the best that are offered.

Fine mixture of leading shades and colors $10 \mathrm{c}$.

Extra choice mixture of best large flowering varleties, 25c

Giant Trimardeau Pansies

Fine mixed $10 \mathrm{c}$.

Cardinal, fine scarlet, very showy $10 \mathrm{c}$.

King of the Blacks 10c.

Golden Yellow 10c

Emperor William 10c.

Light Blue 10c.

Snow Queen $10 \mathrm{c}$

Pure Yellow 10c.

Violas or Tufted Pansies While the Pansy Proper is a spring flower, violas flower tt roughout the entire season. Seeds sown in spring produee flowering plants by June which blooms until frost. Splendid mixed colors, flne varieties. $10 \mathrm{c}$. 
F. H. EBELING, SEEDS AND FARM SUPPLIES, SYRACUSE, N. Y.

Passifiora (Passion Flower) Fine climbing plant tor garden or greenhouse with a profusion attractive flowers; mixed. 10c.

Pentstemom (Beard-Tongue) One of the most beautiful attractive herbaceous plants; bearine long graceful spikes of rich colored flowers: if sown early and transplanted in May will bloov in July until frost, half-hardy perennial; $2 \mathrm{ft}$. mixed colors $10 \mathrm{c}$

erilla Foliage a dark purple, annual ; 2 ft. $5 \mathrm{c}$ pkt.

Petunia For outdoor decoration or house culture few plants equal the Petunia. Commenor flowering early and continue a mixture of bloom until killed by frost, easily cultivated, requir ing a good soil and sunny position.

Sumerob double fringed. $50 \mathrm{c}$.

Double Large Flowering flne mixture. 25c.

Single Varieties

Rufied Giamt Very large, in great variety of colors 25c

Fringed Giant, Very flne. 35c.

Snowball Pure white. 10c.

Striped and mlotched Small flowering. 5c. Fine mixed, all colors. 10c.

PhIox Drummondi of all summer flowering annuals this variety is unquestionably one of the most brilliant and satisfactory. Seed may be sown in open ground after danger of frost past and in a few weeks the beds or borders are all aglow with their brilliant coloring until calt down by the frost. For early flowering they should be started indoors.

Phlox Drummondi Mixed colors. $5 \mathrm{c} \mathrm{pkt.}$

White $10 \mathrm{c}$, pink 10c, rose $10 \mathrm{c}$, scarlet $10 \mathrm{c}$, red $10 \mathrm{c}$.

Dwar Plox This strain of dwarf, compact habit, makes a desirable pot plant, also for ribbor lines and massing; 6 inches high.

Scarlet, white, pink, mixed colors $10 \mathrm{c}$.

DoublePhlin Esp cially fine for cut flowers, lasting better than the single sorts. Sow in light soils. Mixed colors 10c.

Star Phlox (Star of Quedlinburg) Drarf, pretty star-shaped flower. Mixed colors $10 \mathrm{c}$

Hardy Perennial Phlox All colors, mixed $10 \mathrm{c}$.

Pinks (See Dirnthus)

Poppies An extremely popular brilliant flowering annual. Poppies should be sown where they are to remain, as they will not stand trunsplanting.

Single Annual Poppies Shirley's selected Strain 10c, scarlet 5c. white 5c.

Plue Poppy 14 inches high, producing many large tulip-shaped scarlet flowers 100 single mixed 50 .

Oriental Poppy Perennial, exceedingly showy, scarlet with black centre. 10c pkt.

Double Anmual Poppies Mixed colors 5c.

Paeony Flowered Large showy, double mixed colors 5c.

Portulaca (Sun Plant) Fiue hardy annual, of easy culture, thrives best in rather rich ligh: sandy loam and sunny situation, flowers of richest colors, blooming throughout the summer in great profusion, fine for beds, edging or rockwork; 6 inches. Sgl. mixed $5 \mathrm{c}$. Dbl. mixed $10 \mathrm{c}$

Primula Charming beautiful Chinese Fringed Primrose, fine for winter or spring decorations. One of the most important winter-blooming pot plants, sow from March to May. White $50 \mathrm{c}$ pkt. scarlet $50 \mathrm{c}$ pkt. pink 50c pkt. crimson yellow eye $25 \mathrm{c} \mathrm{pkt}$. mixed colors $25 \mathrm{c}$ pkt. Double white 500 pkt. Double mixed 500 prt.

Primula (Obconios Grandiflora) On single white, slight tinge of Hlas. Eiverblooming. 100 pit

Pyrethrum Handsome herbaceous plants or easy culture so much used for bedding edging ete.

Aureum (Golden Feather) Bright yellow foliage, 10c. Donble mixed 25c, single mixed 10c.

Reseda (See Mignonette)

Rhodanthe (Swan River Everlasting) A charming annual; does well in a light rich soll and warm sheltered situation. Fine for pot culture, flowers everlasting. Mixed colors. 5c.

Cicimus (Caster Oil Bean) Ornamental plant of stately growth and picturesque flowers, brillisa colored fruit; flne for lawns or center plants for beds, mixed all colors. 5e.

Phillippiensis $10 \mathrm{ft}$. $5 \mathrm{c}$.

alpiglossis (Painted Tongue) One of the greatest favorites among annuals. Partly on account of its easy sulture, but mostly for its beautiful, almost orchid-like flowers. Mixed sorts 5c pla

Galvia (Flowering Sage) A favorite bedding plant, bea ring long spikes of flowers in great pro. fusion from July until frost, half-hardy perennial, blooms the first year from seed sown indoors and transplanted when weather permits.

Splendens (Scarlet Sage) Beautiful bright scarlet. 10c pkt.

Patens (Blue Sage) 5c.

Scabiosa (Mourning bride or Sweet scabious) A very handsome and autumn border plant witt great profusion of very double flowers. Splendid for table bouquet; hardy anilual; 2 fit Doube mixed. $10 \mathrm{e}$ pkt.

Gcarlet irumner Heans Great favorite of England and continent of Europe, not only as an ornamental climber, but for the delicious edible beans which succeed the bright scarlet blos soms. $5 \mathrm{c} \mathrm{pkt.}$

Gechizanthus (Butterfly or fringe flower) Splendid annual with a profusion of various colored flowers; fine for greenhouse decorations and flower garden, of easy culture. Mixed. 5c pkt

Gmilax (Myrsiphyllum Asparagoides) In many respeots the Smilax is the most useful, and cer tainly one of the most graceful climbers; for bouquets and floral decorations it is indispens. able. Soak seed in warm water for 12 hours and plant in pots. A tender perennial; white; 10 ft. $10 \mathrm{c} \mathrm{pkt}$.

Solanum (Jerusalem Cherry) Very useful pot plant for winter decoration, dwarf branching habit, leaves small and oval shaped, bearing in great profusion bright scarlet globular berrie日 $1 \mathrm{tt} .10 \mathrm{c} \mathrm{pkt}$.

Suapdragon (Seo Antirrhnum)

Crecks (Gilliflower) The stock is one of the most popular annuals, afther- por beding of pos eulture, for brilliancy and diversity of color, fragrance, profusion and duration of bloom is nusurpassed. 


\section{Stocks (Continued)}

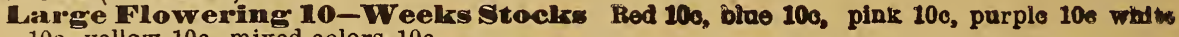
$10 \mathrm{c}$, yellow 10c, mixed colors $10 \mathrm{c}$.

Cutoand-come-again 10-weeks stock Splendid perpetual blooming class. Sow Marot. or April. They begin flowering in June, continuing until srost, and are especially valuable from September to October when other flowers are scarce. They throw out numerous side branches, all bearing fine double flowers. Excellent for cutting. White 10c, rose.15c, rew 15c, blue 15c. Fine mixed colors. 10c pkt.

Cerman Steclrs Half-hardy biennial, double flowers; $2 \mathrm{ft}$. Mixed colors. 100 pkt.

Gunflower Remarkable for their stately growth, size and brilliancy, making a very show? effect among shrubbery and for screens. Single sunflowers are indispensable for cutting. Sow. in a sunny spot in April or May. They come into bloom early in summer and keep up a cov. stant supply of flowers until cut down by frost. 5e pkt. Single dwarf or minature sunflowe: $10 \mathrm{c} \mathrm{pkt}$. Giant Sunflower, $8 \mathrm{ft}$. 5c pkt.

SW EWT PEAS Ebeling's cream of the named Sweet Peas. This is a select list of giant-flowering varieties. We have discarded all small-flowering sorts and duplicates under different names.

America Orimson scarlet, striped on white, large size. $5 \mathrm{c} \mathrm{pkt.} 100 \mathrm{oz}$.

Blamehe Ferry Extra early. The popular pink and white. Comes into flower ten daye earlier than othors. 50 pkt. $100 \mathrm{oz}$.

Daints Pure white edged with pink on the standards and wings. 5o pkt. 10c oz.

Dorothy Eekford The grandest, pure white; very large, produoing onormous mases of blooms. 50 pkt. $100 \mathrm{oz}$.

Cirmeous Brilliant orange salmon. $50 \mathrm{pkt} .150 \mathrm{oz}$.

WIIE Ifdward VII Bright red, giant flowering, very flne, strong stems. 5o pkt. $1000 \mathrm{~g}$.

Lady Arisel I Imilton The flnest pale lavender. $50 \mathrm{pkt} .10 \mathrm{coz}$.

Tottio Eckford Whiteshaded lilac, white shaded, ind edged lavender blue. 50 pkt. $10000_{0}$

Lovely Warm rose, pink, large and extra fine. 50 pkt. $10 c 08$.

Navy Ine Deop indigo blue, medium sire. $50 \mathrm{pkt}$. $10 \mathrm{coz}$.

Dthello Deep maroon, very dark maroon, fine form and large size. 5o pkt. 100 oz.

Prima Donna Soft pink; a magnifoent rich, pure pink; very fine. 50 pkt. 1000.

Prince of Wales The flnest bright rose. 50 pkt. $100 \mathrm{oz}$.

Queen Alexand rea Beautiful Soarlet, Very Brilliant, Handsnme and desirable, 5c pkt. $1000 \mathrm{z}$. Mrs. Wekford Light primrose, large size, semi-hooded form, of the best type. Be pkt. 10e os

Sacie Burpee Pure white, large size, very flne. 5e pkt. 10c oz.

Double Flowering Sweet Peas Finest mired colors. 5c pkt. $10 \mathrm{coz}$.

Sweet Peas Mixed Price, 5c pkt: $100 \mathrm{oz} ; 20 \mathrm{c} 1-4 \mathrm{lb} ; 60 \mathrm{clb}$. Our mixture of sweet peas are mixed under our personal supervision and contain all of the very best named sort known to the trade, and we confldently offer them to most careful and critical buyers. A iner mixtare cannot be found.

Apencer Orchid-Flowred Sweet Peas. The introduction of this type has oreated new Interest and added to the popularity of Sweet Peas. They are quite distinct from the Standard sorts, having large, round, open flowers, extraordinary size, measuring two inches acrose wary standards, wide spreading wings, a very large pereentage bearing four im mense blossoms to the stem, which is long and strong, making them of exceptional value for cutting All have been thoroughly tested and are just as easy to grow as the standard varieties. 10c pkt. $200 \mathrm{oz}$.

Sweet Focket (Hesperis) Old-fashioned garden plant, also known as Dame's Rocket Dame's Violet; 2 to 3 ft. high, with spikes of showy white, lilac and purple fragrant flowers flue for shrubbery and permanent border; mixed colors. $5 \mathrm{c}$ pkt.

Sweet Sultan See Centauria.

Sweet William (London Tufts) A well-known attractive free-flowering hardy perennial, an for beds and shrubbery; 1 1-2 ft. Sgl. mixed 5c. Double mixed 5c pkt.

Taoetes (Seo Marigolds and Calendula)

Sionata Pumila A dwarf, compact, bushy, annual marigold with beautiful delicate fern like leaves, densely covered with flowers of bright yellow striped brown; flue border plant $5 \mathrm{c}$ pikt.

Thumbergia (Black-eyed Susan) Beautiful rapid-growing climber used especially for hangine baskets, low fences, etc., flowers in buff, white orange, etc., with dark eyes; mixed colors $5 \mathrm{c}$ pkt

Torenia Fine annual; splendid plant for vases, hanging baskets, borders etc., blooming the. entire season. Blue, white, and yellow. 100 pkt.

Tritoma (Red Hot Poker Plant) Readily grown from seed. Will bloom first year if sown eariy Tritomas are becoming very popular for bedding plants and out flowers; hardy perennial; 4 it Vary in color from light and deep orange, salmon and carmine. 10e pkt.

Tropaeolum (See Nasturtium)

Verbemas One of the most popular and free-blooming varieties and so well known that a des cription of this variety is unnecessary. Half-hardy perennial; easy of culture; sow early and transplant when weather permits. Fine for beds, baskets, rockeries, eto. Soarlet 10c, variegat ed $10 \mathrm{c}$, white 10c, mixed colors 10c.

Vola (Seo Pansios)

Vinca (Madagascar Periwinkle or old Maid) Ornamental free-blooming plant, fine for bedding flower from seed the first season continuing until frost, or they may be potted and kept ir bloom through the winter, $2 \mathrm{ft}$. Rose $10 \mathrm{c}$, white $10 \mathrm{c}$, mixed $5 \mathrm{c}$.

Wall Flower (See Cheĭranthus) Half-hardy perrennial, 1 1-2 ft high. Mixed $50 \mathrm{pkt}$.

Wild Cucumber (See Echinocystis.) 50 pkt.

Wild Nlower Gareden 5e pkt.

Tim niens (Youth and Old Age) One of the most brilliant and showy of annuals. An old and con tinued favorite. The seed can be sown early and transplanted or sown later in open groun. They come into bloom early in summer, and continue until hard frost.

Dwarf double white, orange scarlet, rose, etc. 5c. Tall double mired 6a. Dware alngle mired 


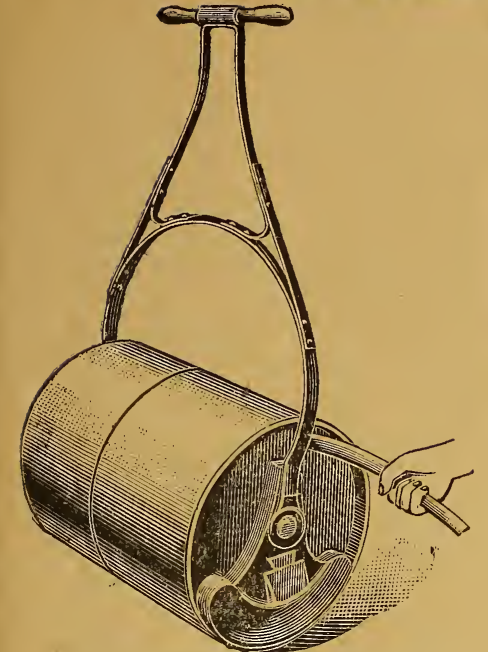

Dunham Lawn Rollers ROLLER BEARING

$\Delta r e$ inflnitely superior to other roll. ors. In eflieienoy, being 44 per cent. lighter running than any other roller on the market by actual tests. With a Dunham a boy can do the work that requires a man's strength with other rollers of the sameweight. 200 lbs.\$11; 250 lbs. \$12; 300 lbs. $\$ 14$

Water-weight Roller

The Dunham Ball-bearing Waterweight Roller is made in one section and eleetric-welded, no rivets being used so the water cannot possibly loak out. The weight of this roller oan be increased or diminished by inereasing or decreasing the water. Very simple and easy to handle and revolutionizes the work of rolling. When not in use the water can be let out if desired. Prices $\$ 12.00$ to $\$ 16.00$

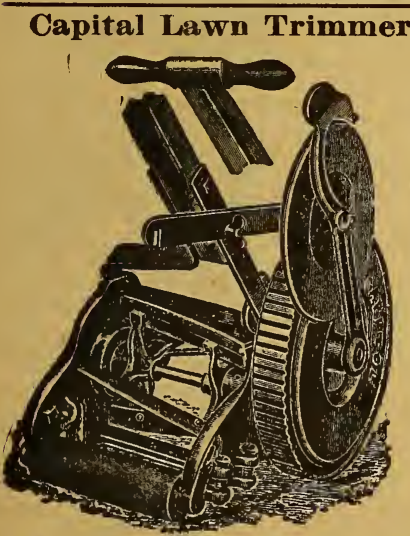

For trimming around walks, lower beds, trees, posts, monuments and shrubbery, and all places that cannot be reached with any lawn mower. Cuts within one fourth of an inch of the edge.

Has a revolving cutter with four oruolble steel blades, tempered in oil and outs six inch $\theta$ wide. PRICE $\$ 6.00$

\section{FOREST CITY BALL BEARING}

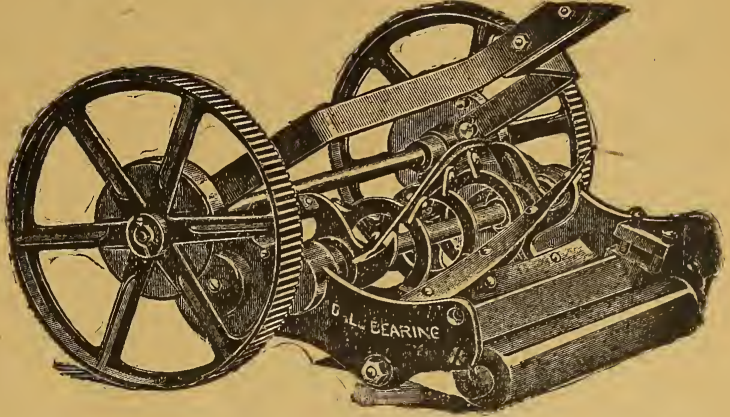

This unquestionably is the Best BALI BrARING MowrB on the market. Perfect in detail, absolutely guaranteed.

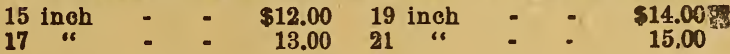

\section{HIGH WHEEL IMPERIAL}

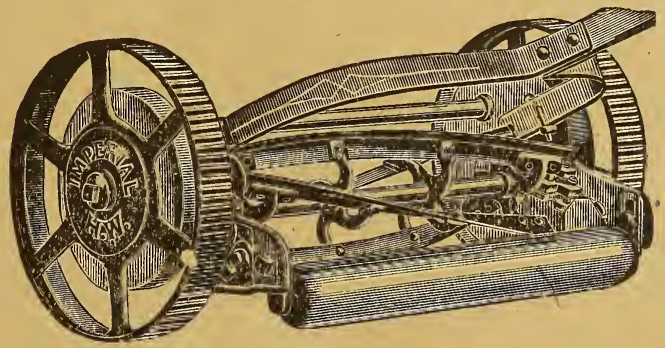

Absolutely Warranted for Two Years. Positive Adjusteneat. Has no Equal. In Public Parks, Private Lawns aad Cemeteries everywhere. Ask for Special Catalogue.
16 inch - $\$ 10.00$
18 " $\quad 11.00$
20 " - 13.00

\section{IMPERIAL HORSE LAWN MOWER}

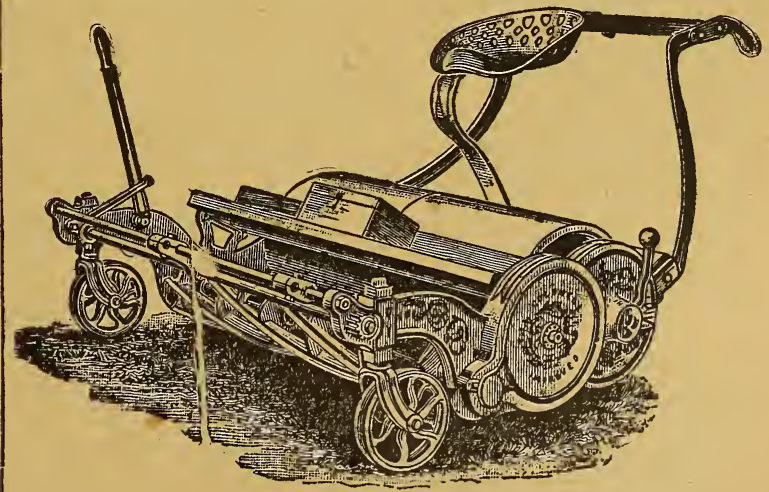

PIECE, \$60.00 ANID UP.

Absolutely Guaranteed to Cut Clean in turning around. Send for Catalogue. 
F. H. EBELING, SEEDS AND FARM SUPPLIES, SYRACUSE, N. Y.

SPRING PLANTS, BULBS AND ROOTS.

PER DOZ.

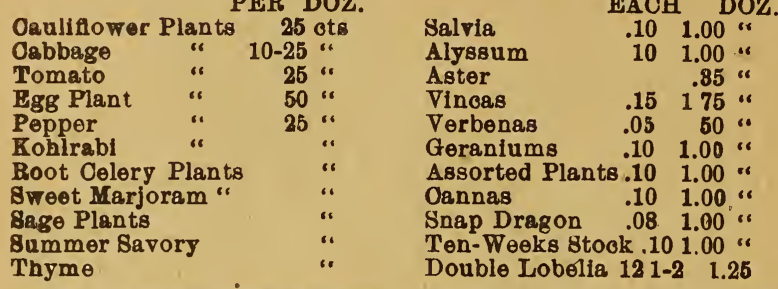

EACH DOZ.

For-get-me-not .10 1.00 “

Dracaena $\quad .101 .00$ “

Petunis $\quad .50$ “.

Pansy . .40 “

Beautiful Japanese Fern

Balls each 50 .

Porch hanging baskets $\$ 1.25$ to $\$ 2.00$

Moss tor hanging .15 per lb.

Oalladiums, Gladiolas, Dahlias, Tube-Roses, Tuberous Begonias, Maderia Vines, Peonies, Gloxinlas.

\begin{tabular}{|c|c|c|c|c|c|c|c|c|c|c|c|}
\hline . & & $\mathrm{FL}$ & $\mathrm{MAI}$ & Y I Z E & D & LI I & YDC & $\operatorname{skr}$ & BOX & ES & \\
\hline No. & Helght & Width & Length & $\begin{array}{l}\text { Water } \\
\text { Capacity }\end{array}$ & Price & No. & Height & Width & Length & $\begin{array}{l}\text { Water } \\
\text { Capacity }\end{array}$ & Price \\
\hline 0 & 6 -in. & 6 & 16 -in. & 1 qt. & $\$ 1.50$ & 6 & 8-in. & $91 / 2$ & 33-in. & $5 \mathrm{qt}$. & 3.00 \\
\hline 1 & 8 -in & $91 / 2$ & 23-in. & $23 \mathrm{gt}$. & 1.75 & 7 & 8-in. & $91 / 2$ & 35-in. & $51 / 2 \mathrm{qt}$. & 3.25 \\
\hline $\begin{array}{l}2 \\
8\end{array}$ & $\begin{array}{l}\text { 8-in. } \\
\text { 8-in. }\end{array}$ & $\begin{array}{l}91 / 2 \\
91 / 2\end{array}$ & $\begin{array}{l}25-\operatorname{in} . \\
27-\ln .\end{array}$ & 3 qt. & $\begin{array}{l}2.00 \\
2.25\end{array}$ & $\delta$ & 8-in. & $91 / 2$ & 37-in. & 6 qt. & 8.50 \\
\hline 4 & 8-in. & 0 & 29-in. & 4 qt. & 2.50 & 9 & 8-in. & $91 / 2$ & 39 -in. & $61 / 2 \mathrm{qt}$. & 276 \\
\hline 5 & 8-in. & 9 & 31-in. & $41 / 2 \mathrm{qt}$. & 2.75 & 10 & 8-in. & $91 / 2$ & $41-1 n$. & qt. & 4.00 \\
\hline
\end{tabular}

\section{FLORISTS; SUNDRIES}

Self Registering Thermometers

Hanging baskets

Tin Foil

Green Moss

Norist Letters

Rafils and Reed

Flower Supports

Plant Stands

Trellisses

Immortelles

Mastica

Plant Lables

Fumigators

Bulb Syringes

Glazing Polnts

Flower Pots

Hyacinth Glasses

Shears

Scissor 3

Fine Cutlery

Syringes for Plants

Flower Pot Brackets

Sharpening of Shears, etc.

Lawn Seed and Fertilizers

Bird Supplies

Wire Plant Supports

Silkaline, per spool, 30 cents

\section{STRAWBERRY PLANTS}

We are pleased to announce that we can furnish choice thrifty STRAWBERRY and RASPBERRY Plants of all tho lesding varleties and recommend them to our oustomers.

Strawberry Plants 750 per 100 ; Raspberry Plants $\$ 1.50$ per

100. Leave orders early.

\section{BERRY BASKETS.}

Under the new law all Berry Baskets must be made up to the standard size. We offer Berr Baskets of correct size and shape and well made. Prices right. Our Baskets fit the Crate perfectly. We can save you money on berry baskets if you place orders early. Call and see us before buying.

\section{GRAPE BASKETS}

We carry a large stook of Grape Baskets at the lowest market price.

\section{FLOWER TUBS, ALL SIZES}

$\$ 1.00 \$ 1.50 \$ 2.00 \$ 2.50 \$ 3.00 \$ 4.00$
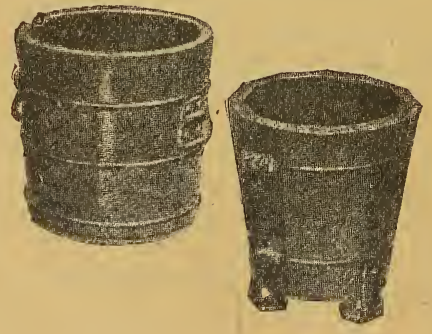

Flower Pots

Hanging

Baskets

Fern Pans

Lily Pans

\section{TRELLISES, URNS, VASES, SETTEES.}

We offer a fine variety of styles in various sizes suitable for lawns front, yards, cemeteries, parks etc. These can be furnished toorder on short notice, at reasonable prices. For full particuars, write or call and see us.

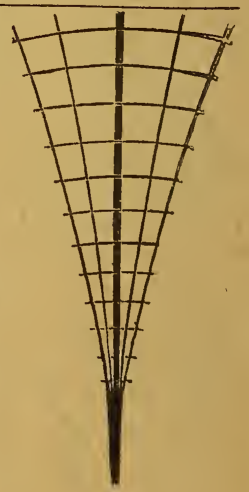




\section{MASTICA FOR GLAZING GREENHOUSES, SASHES,}

Etc., new and old. It is elastic, adhesive and easily applied. It is not affected by dampness, heat or cold.

Every green house man has experienced diffoulty in using putty for glazing, that is satisfactory for any length of time. Putty is not adapted for greenhouse work. "Mastica," when applied, in a few hours forms a skin or fllm on the entire mass, hermetically sealing the substance, and preventing the evaporation of the liquids, and remains in a soft, pliable and elastic condition for years. "Mastica" is of great value in going over old houses with a putty bulb or machine on the outside of sash, as it makes it perfectly tight and saves the expense of re-la ying the glass.

The use of "Mastica" avoids the necessity of repeatedly reglazing the houses, saving much time and expense. With "Mastica" you can bed in or use outside with machine.

Broken glass can be easily removed and replaced by new without the breakage of other glass, which usually occurs with hard putty. One gallon will cover about 290 running feet (one side.)

Price of Mastica $\frac{1}{2}$ gal. 80c., gal. $\$ 1.50$.

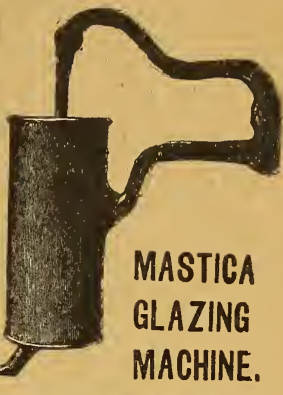

PRICE \$1.50.

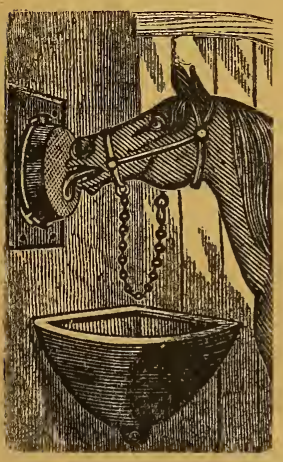

Roto Salt Cakes and Frames

For Horses, Cattle and Sheep. Pure Reflned Salt. Aots as a tonic; Invigorates the system; promotes digestion; purifies the blood. Makes healthy and vigorous animals.
25C. CAKE
Five Cakes for One Dollar
per dozen Two Dollars

Frames, - $\quad$ - $\quad$ - $\quad$ - $\quad$ - 25 Cents

\section{Climax Handy Weeder}

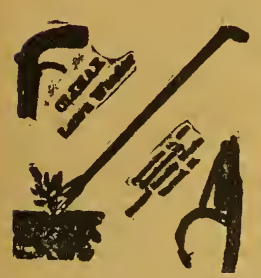

The greatest "little" device ever invented.

Nothing like it.

Thousands in use.

$$
\text { PRICE, } 75 \text { GENTS }
$$
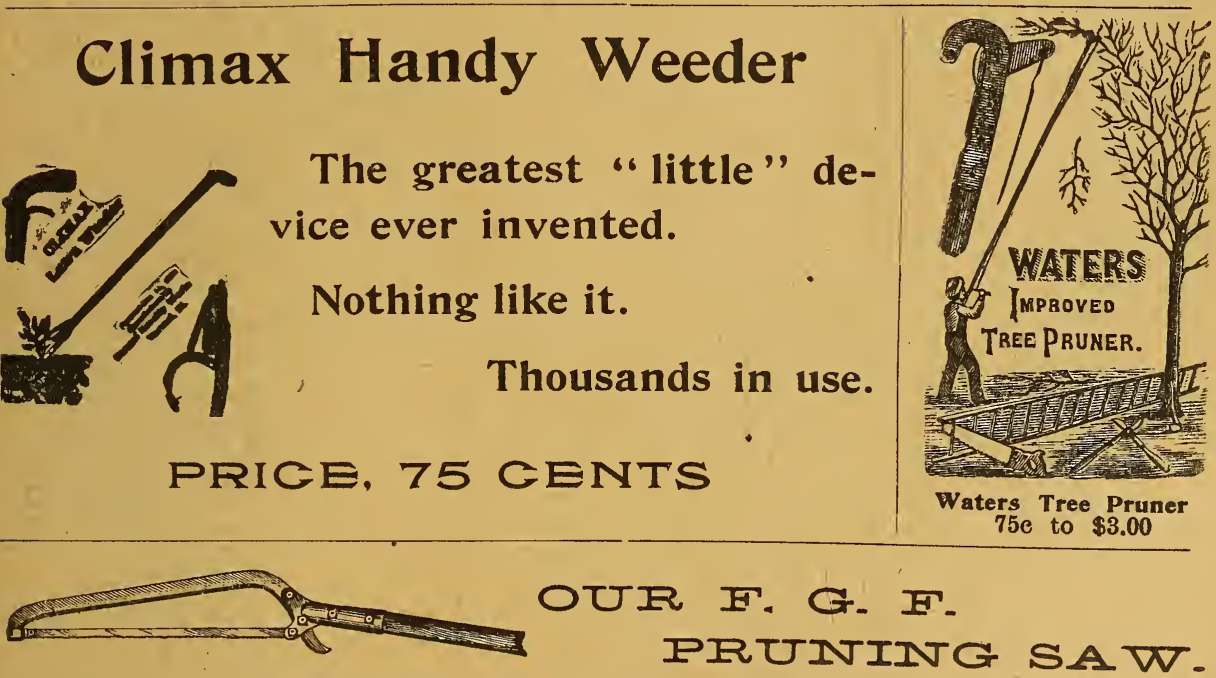

This is a very practical Pruning Saw, and is recommended by the Nurseries and Hortioultural Societies everywhere. It is a self-feeding draw cut blade with a thin back that will not pinch or bind; may be attached to a pole, permitting very rapid work. It will do three times the work of hand saws or shear trimmers. It has no equal for outting out snckers and for trimming the outside and tops of trees so diffoult to reach. No stubs are left. It covers all the features requilred for an up-to-date labor-saving tool. 


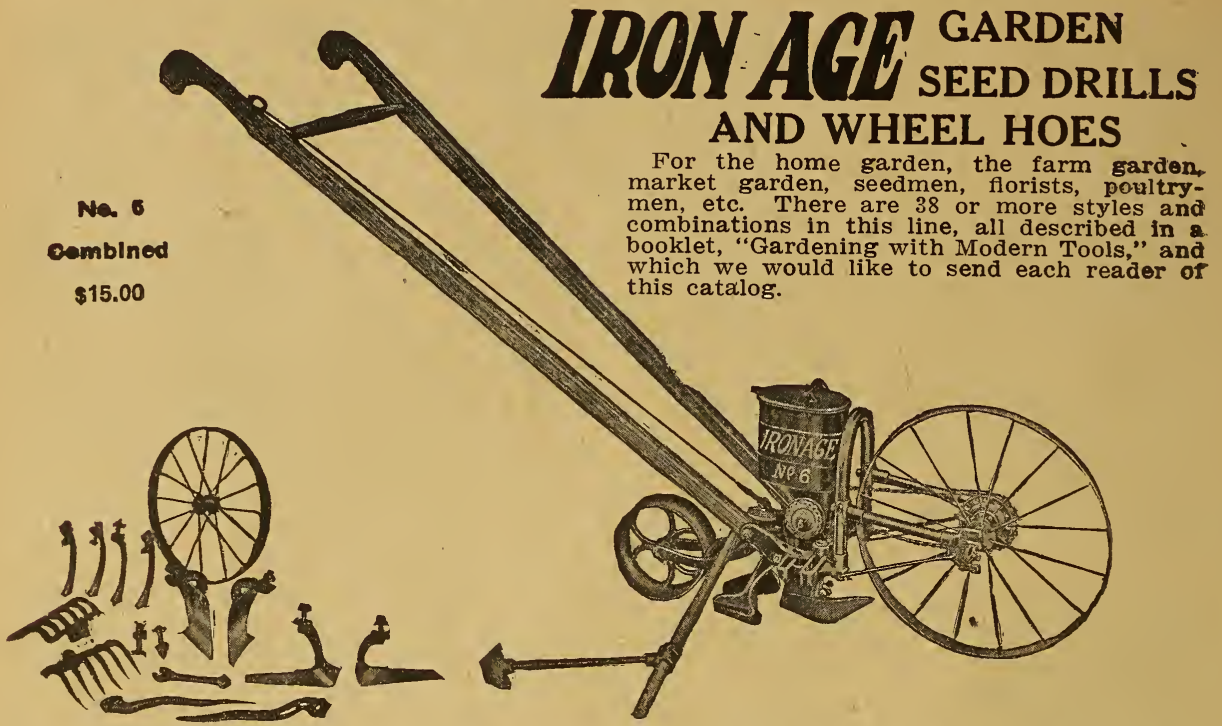

No. 6 Comblned HIII and Drill Seeder, Double and Single Wheel Hoe. Sows accurately any small garden or flower seed, in continuous rows or in hills, 4 to 24 inches apart, opens It own furrow, covers the seed and rolls it, and marks the next row. Sows where you care sov it drop. Adjustable index permits you to sow as thick as your experience tells you is right. The shut-off is connected at the handles, at your finger ends. Includes all cultivating tools shown with it and described under No. 1 Wheel Hoe on the next page.

Packed weight, 57 pounds. If wanted as drill only order as No. 7. See illustration.

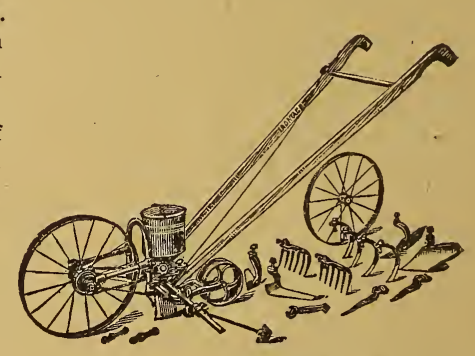

No. 4 Combined, $\$ 13.75$

No. 4 Combined Drill Seeder, Double and - Single Wheel Hoe is same as No. 6 except that it is arranged to sow only in continuous rows and it has a different opening plow. If wanted as a drill only order as No. 5, Prlce $\$ 10.00$. Is also furnished as drill with side hoes and cultivating teeth, No. 40 , Price $\$ 12.00$.

No. $7 \mathrm{Hill}$ and Drill Seeder, $\$ 11.25$

NEW MODEL SEED DRILL. Is strongly built and made to sow accurately in continuous rows, any thickness wanted. Opens its own furrow, covers the seed and rolls it. Also marks the next row Index helps you to set right for sowing. Flow of seed can be cut off instantly. Adjustable marker. Capacity two quarte. Sows all kinds of reed.

\section{Ask for}

\section{special IRON AGE booklets giving full descriptions.}

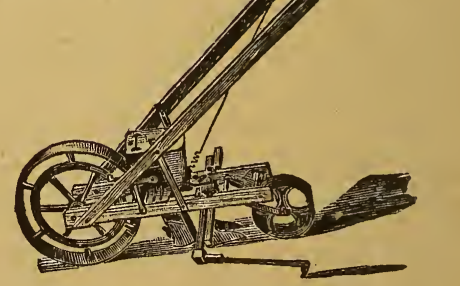

New Model Seed Drill, $\$ 9.00$ 
F. H. EBELING, SEEDS AND FARM SUPPLIES, SYRACUSE, N. Y.

\section{IRON AGE WHEEL HOES}

NO. 1 DOUBLE AND SINGLE WHEEL HOE, Works astride or between the rows. Can be changed from double to single wheel in 3 minutes. This is the Wheel Hoe form of No. 6, and will take seeder attachment any time. Price of attachment, $\$ 5.50$. The tools include pair each side hoes, plows and rakes, also four steel cultivator teeth, all adjustable on the
frame to suit width

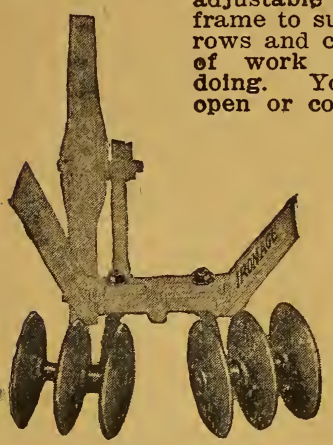

Fig. 369,

Disc Cultivating

Attachment,

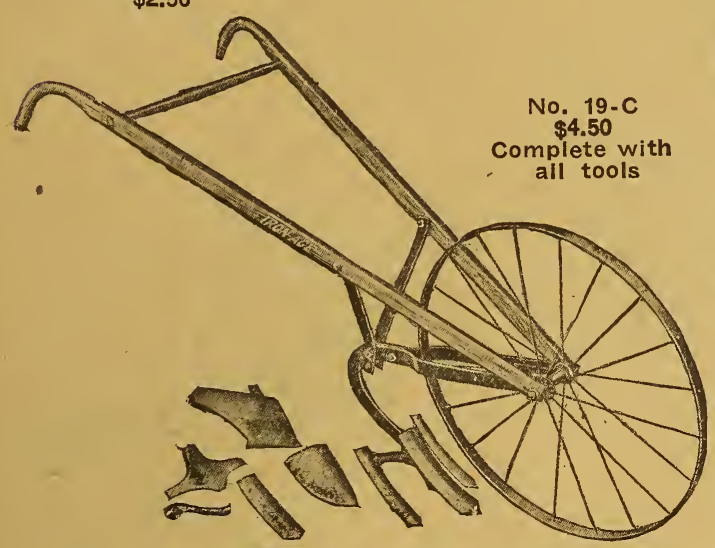
vating Attachment, Fig. 369,

Landside Plow Attachment.

Fig. 82, and many others.

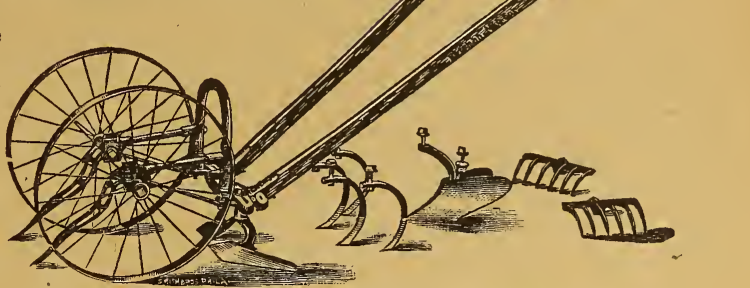

No. 1 Double and Single Wheel Hoe, $\$ 8.75$

rows, ridge growing crops, cultivate, hoe close to plants without danger to them, pulverize and level the soll, and so forth. Bteel tube frame, 16-inch steel wheel, bicycle style. Adjustable handles. Is pushed ahead a step at a time in a natural way. Is sold complete as No. 1 or as No. 3 with side hoes only. Takes Disc Cults-

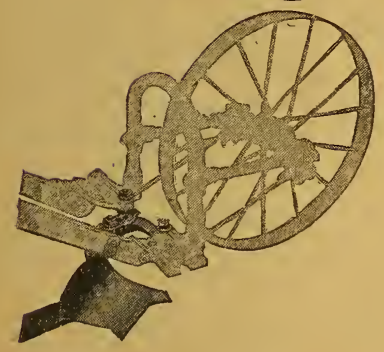

NO. 20 SINGLE WHEEL HOE, CULTIVATOR, ETC. Will do practically same work as No. 1 except that it is meant to 8 between rows only. Seed attachment can be used on it if wanted. If wanted with side hoes only, order as No. 21, Price $\$ 4.50$.

Fig. 82,

Landslde Plow Attachm't, $\$ 1.15$

Ask for Iron Age Booklet, "GARDENING WITH MODERN TOOLS."

No. 20 Complete Price $\$ 7.50$

No. 19-C Wheel Cultivator and Plow Has extra high steel wheel-24 inches -which some sections seem to prefer. The frame is an all steel arch in three parts-compact, light, durable. The working tools are attached in position easily and are adjustable. The plow is noted for turning a fine good furrow.

The cultivating tools include Landside Plow, Scuffle Hoe, two separate Cultivator Teeth, Set of Cultivator Teeth on bracket.

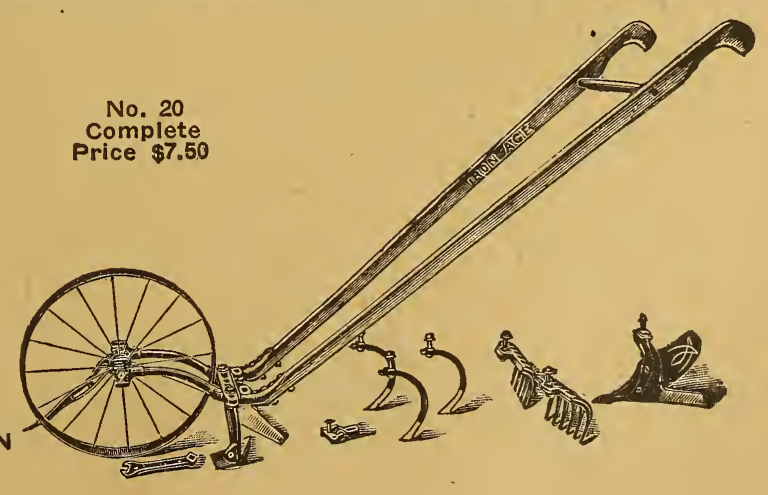




\section{TON GY HORSE' HOES AND CULTIVATORS}

Ask for complete new booklets on

Horse Hoes, Harrows and Two-Horse Walking Cultivators.

These tools are all made standard and you can purchase them in their simplest forms and build up to whatever your ground or crops need-- with or without lever expander, with lever or plain wheel or without either, etc. Long, high steel frames, make them run steady and clear of trash.

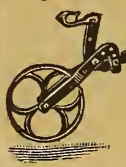

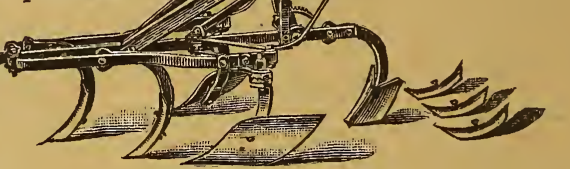

No. 600 E P \$8.00.

With lever expander and plain wheel.

No. 600-EP Horse Hoe and Cultivator has a range of cultiva.

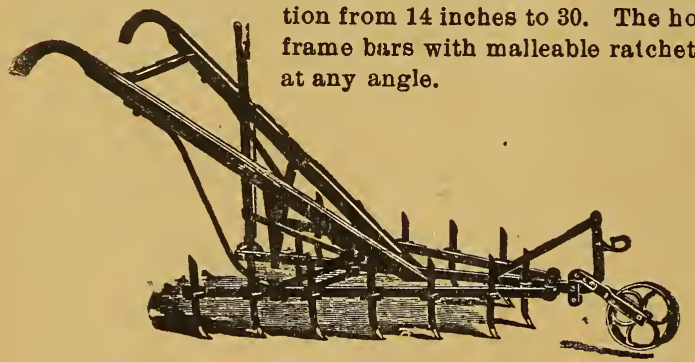
he hoe standards are solid steel, attached to 1 be frame bars with malleable ratchet castings that give adjustments to the hoes at any angle.

No. 1014 E P $\$ 6.90$.

No. 1014-EP Harrow and Cultivator carries 14 diamond shaped steel teeth with a small cultivator point forged on one end. It is adjustable for many kinds of crops and may be used as a Harrow or Cultivator. Opens to $34 \mathrm{in-}$ ehes and closes to 11.

No. 1007-EP Seven Tooth Cultivator. Especially adapted for first workings or in level cultivation. The teeth are narrow and cut deop, throwing small furrows that do not harm the young plants. Thorough oultivation in all oolls. Opens to 24 inches and closes to 10.

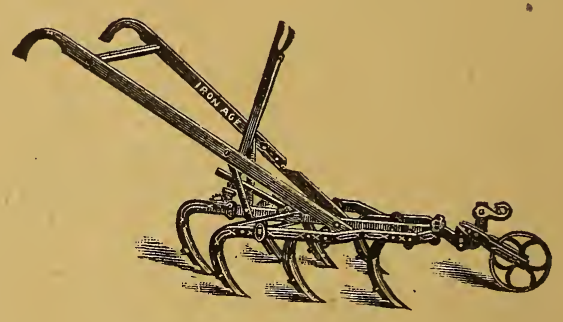

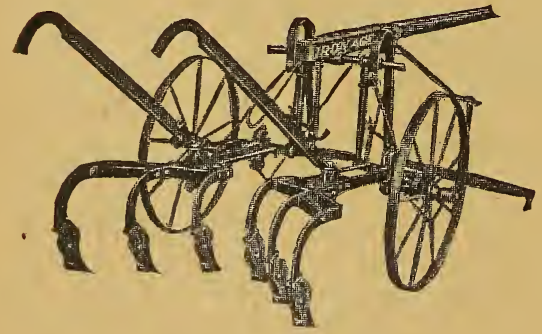

No. 976 . \$26.00.

\section{Two-Horse Walking Cultivators.}

These are halanoe frame machines that are often used on steep hillsides or in very rough ground.

The gangs shift in parallel lines, the points always face one way and the bandles are adjustable to permit the operator to work astride the row or at one side. The wheels are steel and adjustable on the arch from 36 to 48 inch rows. Built with 6 or 8 break pin or spring hoes or with spring teeth.

\section{ASK FOR IRON AGL BOOKLETS}




\section{F. H. EBELLNG, SEEDS AND FARM SUPPLIES, SYRACUSE, N. Y.}

\section{IDON AGE FERTLIZER I.OM AGL DISTRIBUTORS}

These are for use in gardens or on truck farms.

NO. 22 sows the fertilizer and seed at same operation. Opens two separate furrows for fertilizer and covers with soil before opening furrow for the seed. Covers the seed, rolls it and marks the next row. Distributes fertilizer thoroughly and sows the seed with practically the same seeding attachment as on No. 6 Combined. No. 22 can be used for side dressing and includes pair of extra wheels to travel astride the plants.
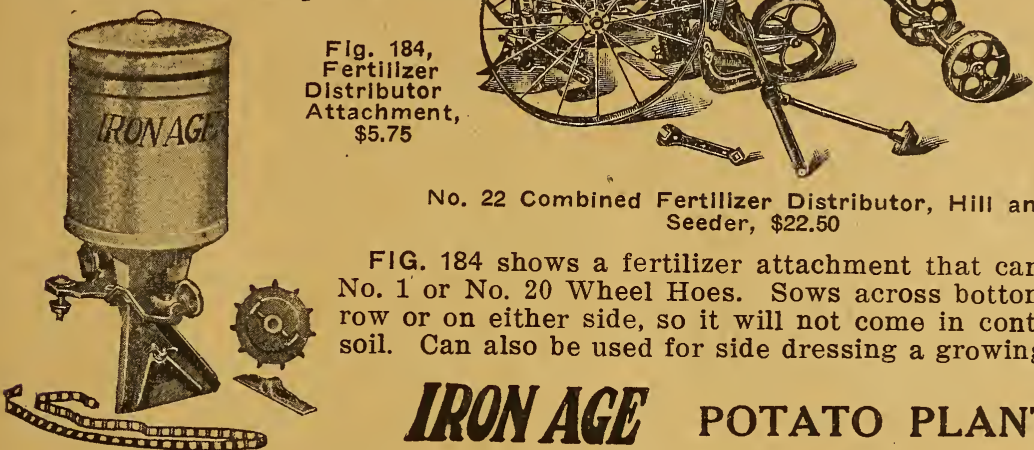
No. 22 Combined Fertllizer Distributor, $\mathrm{Hill}$ and Drill
Seeder, $\$ 22.50$

FIG. 184 shows a fertilizer attachment that can be used on No. 1 or No. 20 Wheel Hoes. Sows across bottom of the furrow or on either side, so it will not come in contact with the soil. Can also be used for side dressing a growing crop.

Plants one seed piece in every space and one only. Makes a perfect stand possible and saves at least one bushel of seed per acre. Straight rows, even depth and uniform spacing. Can plant 9 to 24 inches apart. Furnished with or without fertilizer distributor, regular or large size. Also, with seed box extension if wanted. Steel seed box. Steel frame. Choice of four styles of opening

\section{IRONAGE POTATO PLANTER}
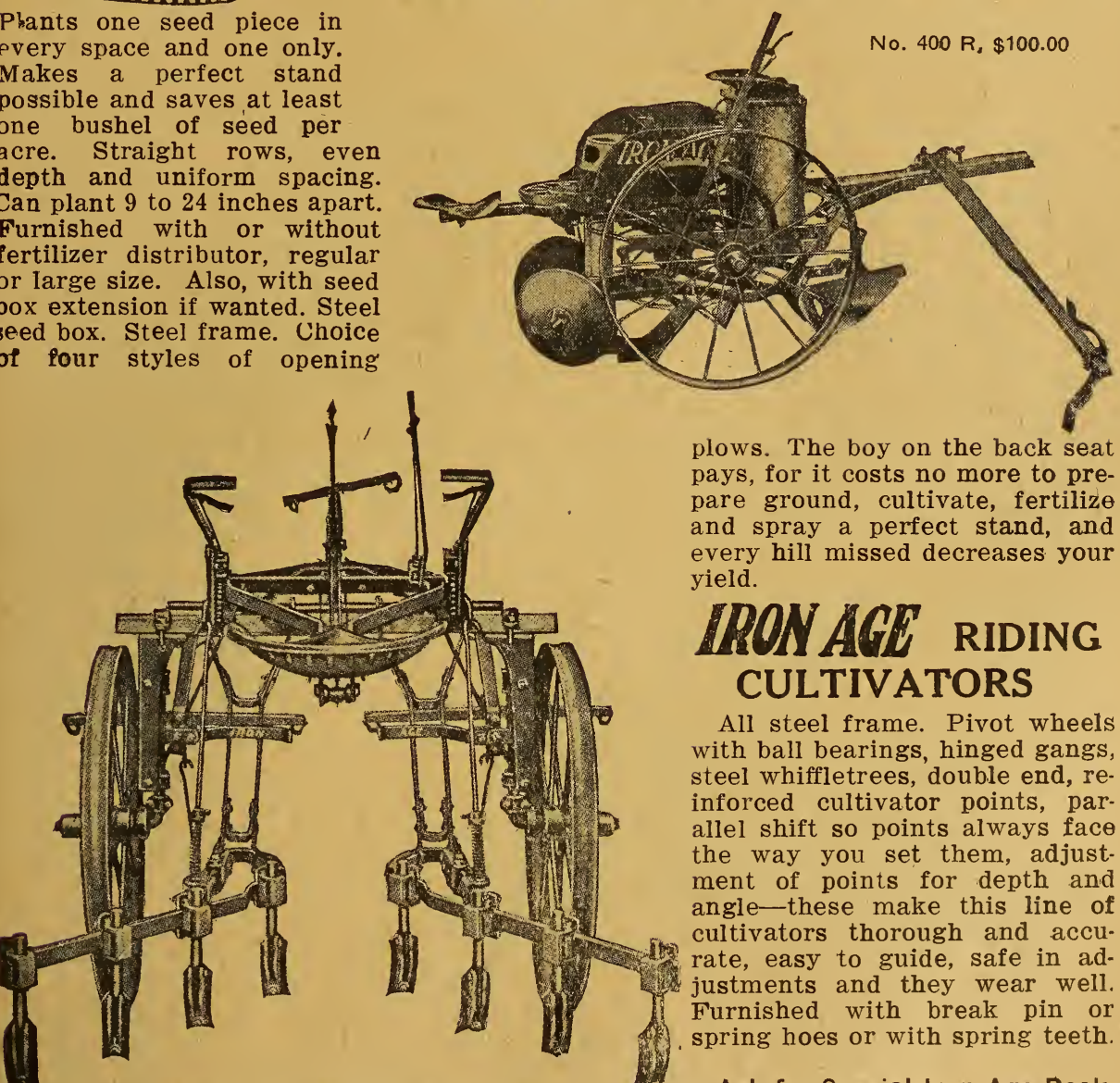

No. 78-All Steel Pivot. Wheel Riding Cultivator, Price $\$ 40$

plows. The boy on the back seat pays, for it costs no more to prepare ground, cultivate, fertilize and spray a perfect stand, and every hill missed decreases your yield.

\section{IRON AGE RIDING CULTIVATORS}

All steel frame. Pivot wheels with ball bearings, hinged gangs, steel whiffletrees, double end, reinforced cultivator points, parallel shift so points always face the way you set them, adjustment of points for depth and angle-these make this line of cultivators thorough and accurate, easy to guide, safe in adjustments and they wear well. Furnished with break pin or spring hoes or with spring teeth. lets on each line. 


\section{IDON AGE SPRAYERS For Every Purpose}

There are more than 70 combinations suitable for all kinds of spraying, and most of them can be built up on the unit plan so that you can buy what you need now and the balance as you require it.

\section{No. 192 Bucket Pump}

is mode of brass and so put together that anyone can quickly get at any part for cleaning or repairs. Bronze ball valves, candlewick packing, pressed brass nozzle.

No. 187 is same pump gâlion barrel, on steel wheels, with four feet of steel pipe. Pump is detachable in less than a minute. A good outfit for disinfecting stock bullaings or any other spraylng.

No. 190 is 50 -gallon horizontal barNo. 190 rel rig, mounted for use in any wagon, cart, etc. Pump, single or double acting. Can be built into a 50 -gallon power rig or combination hand and power outfit. Automatic mixing of solutions.

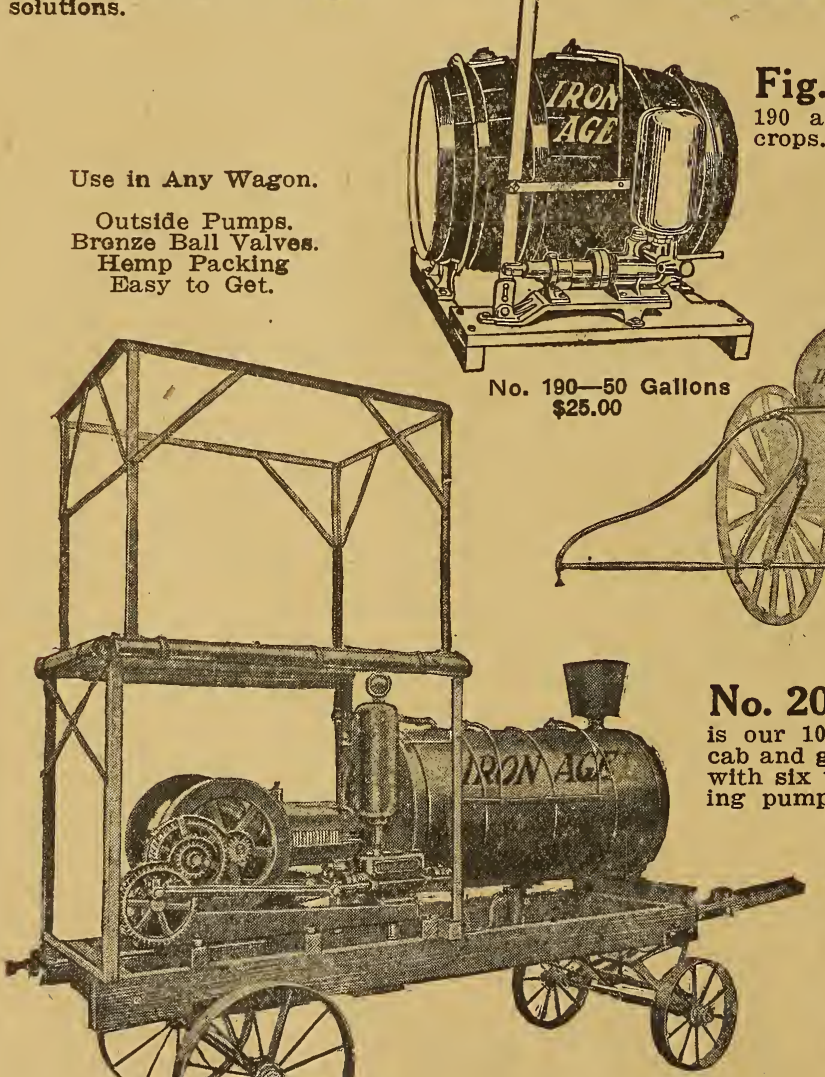

Fig. 457 shows 4-row attachment for use with No. 20 Gallon
Barrel Sprayer No. 192 Bucket Pump

$\$ 7.50$

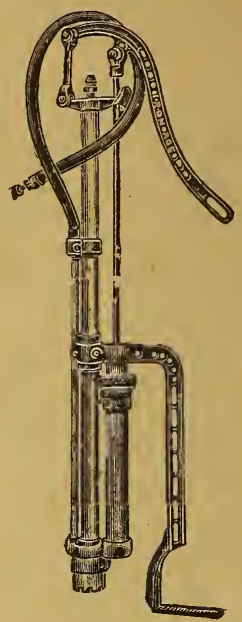

Fig. 457

Four Row Attachment $\$ 13.50$ 


\section{TRACTION SPRAYERS}

\section{For Potatoes and other row crops}

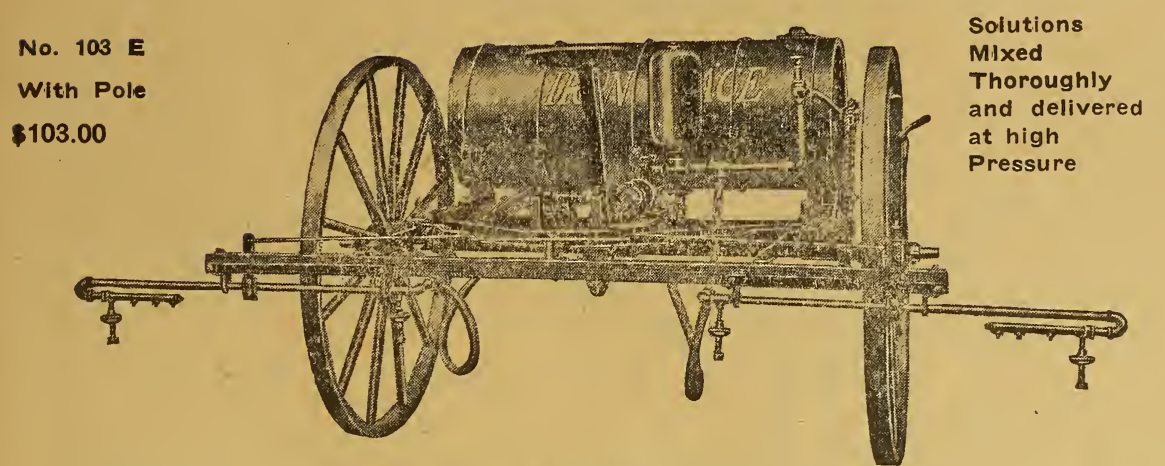

For potatoes and other row crops. Made in 4 or 6 rows, with 50 or 100 gallon wood tanks, wood wheels, single or double acting pumps, thorough mixing of solutions, large air chamber, bronze ball valves, bemp packing-all easily gotten at, relief valve to regulate the pressure, center drive by chain, pressed brass nozzles and nozzle strainers with every outfit, also wind shift. Spraying not only insures your crop against blight, which no amount of spraying can cure, and kills the bugs in a hurry, but every spraying actually improves the healthy condition of your plants and so increases the yield per acre. Takes an orchard attachment at a moderate priceentirely practical in small orchard.
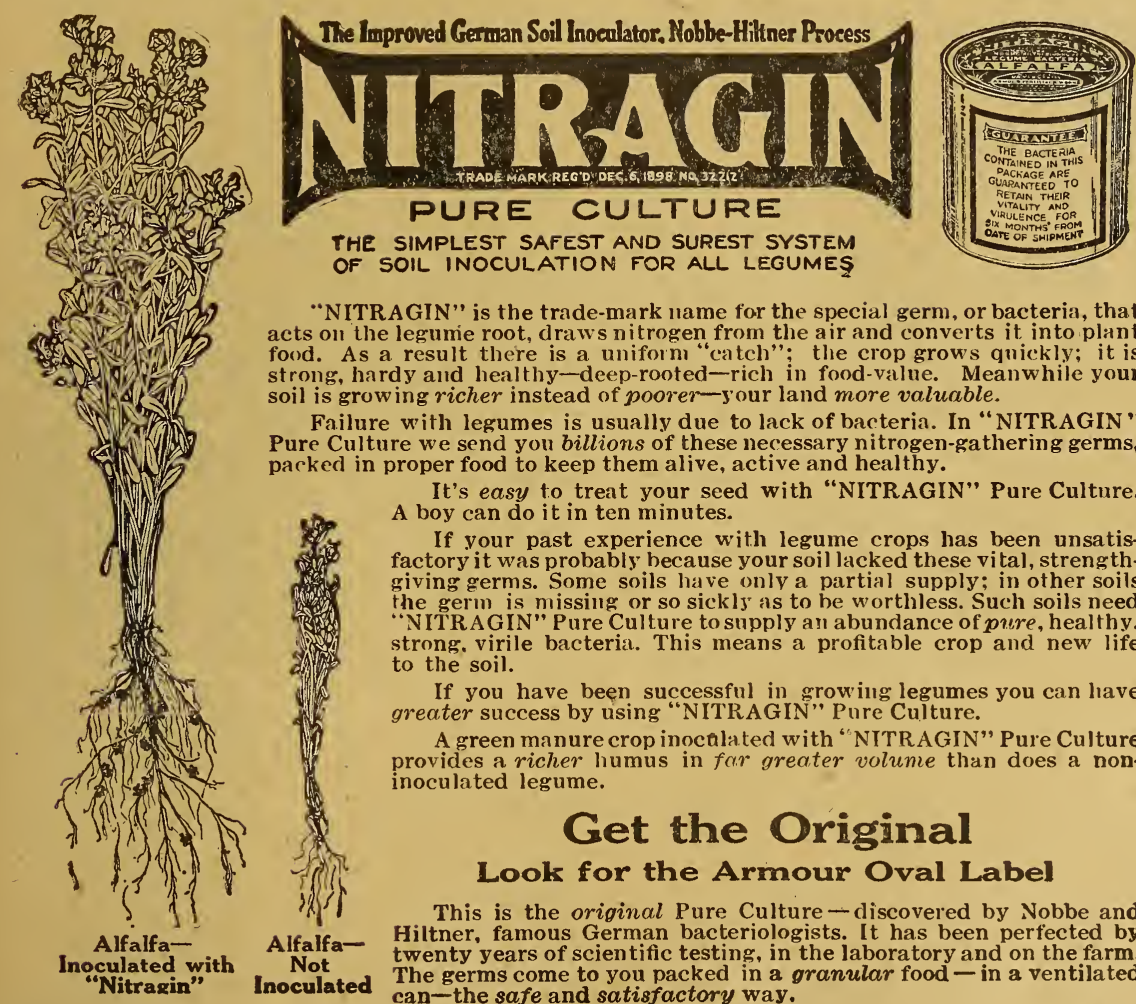

"NITRAGIN" is the trade-mark name for the special germ, or bacteria, that acts on the legume root, draws nitrogen from the air and converts it into plant food. As a result there is a uniform "catch"; the crop grows quickly; it is strong, hardy and healthy-deep-rooted-rich in food-value. Meanwhile your ing richer instead of poorer-your land more valuable.

Failure with legumes is usually due to lack of bacteria. In "NITRAGIN" Pure Culture we send you billions of these necessary nitrogen-gathering germs,

noculated
It's easy to treat your seed with "NITRAGIN" Pure Culture. A boy can do it in ten minutes.

If your past experience with legume crops has been unsatisfactory it was probably because your soil lacked these vital, strengthgiving germs. Some soils have only a partial supply; in other soils the germ is missing or so sickly as to be worthless. Such soils need "NITRAGIN" Pure Culture to supply an abundance of pure, healthy, strong, virile bacteria. This means a profitable crop and new life to the soil.

If you have been successful in growing legumes you can liave greater success by using "NITRAGIN" Pure Culture.

A green manure crop inocalated with "NITRAGIN" Pure Culture provides a richer humus in far greater volume than does a noninoculated legume.

\section{Get the Original}

\section{Look for the Armour Oval Label}

This is the original Pure Culture-discovered by Nobbe and Hiltner, famous German bacteriologists. It has been perfected by twenty years of scientific testing, in the laboratory and on the farm. The germs come to you packed in a granular food - in a ventilated can-the safe and satisfactory way.

Prices per can: Garden size, $\$ 1.00$; acre size, $\$ 2.00 ; 5$-acre size, $\$ 9.00$. F. O. B. Syracuse. Express Extra. Parcel Post, 10c per acre extra. 


\section{The Two Greatest Insecticides SIMPLE, EFFECTIVE, ECONOMICAL LIME AND SULPHUR-PYROX BOWKER'S LIME AND SULPHUR}

Every spring when the buds are swelling, but before they show green at the tips, all your frul! urees, vines tnd shrubs of every kind should be sprayed with our Bowker's Lime-Sulphur Appiteations made l lier than this may burn the foliage and cause serious injury. Therefore you shonld order earlv and be prepared for the season.

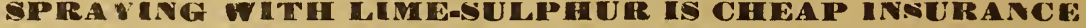

It's better than most insurance because every time you spray you reap a beneft, whether you bave San Jose Suale present or not It kills all forms of scales and bark lice which are alwa. present, the leat blister mice, the eggs of many insects and the fungus spores whloh are lodged on the bark. It oheoks th $\rightarrow$ growth of mosses and lichens and cleans up the trunk and the large branches

Gime- iulphur is not a poison and kills only by coming directly in onntact with the Insect. It does uot kill leaf-eating insects. Bpray for these with our Pyroz.

Our Lim $y$-sulphur has fungicidal properiles and is invaluable for use on peaches, plums and all etone fruits.

It's in concentrated solution, always ready for Fall, Winter and 8pring use. You simply add spring water and then spray.

A.NALY\$1 $\$$-Gravity (B)aung) 32 to 35 ; Calclum Polysulphides and Finosulphate 27.50 to 38.50.

1 gal. 65c.; 5 agal. $\$ 300$; 10 . gal. \$3.50; barrels sec 16 cts. per gal.

\section{BOWKER'S PYROX-KILLS AND CURES}

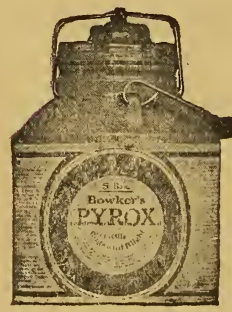

Pyrox sticks like paint; kllls all leafeating insects, and prevents diwease on potatoes, fruit trees, shade trees, and small fruits and vegetables It serves the purpose for which two mixtures were previously used, and has done so for over ten years. Pyrox is no experiment; It was introduced in 1898.

It combines non-burning Arsenate of Lead with non-burning Bordeaux Mixture-both thoroughly tried-out remedies-in the shape of a dense, heavy, oreamy paste that looks like paint is easily mixed with cold water, and sticks like paint to the foliage. It won't wash nff.

Bowker's Pyrox is something nore than a combination of Arsenate of Lead and Bordesux. It is a mixture with reliability and prains bohind it; a mixture wit 3 laboratory and fleld experienoe to support it; a toixture mad by cureful method ia a modern plant under expert supervision. Such a combination costs more to make and is worth more to buy because of the insurance the name a inrds against haphazard prepartations. Pari; Green and Bordeaux applied togerher or separately never adbere through beavy rains like Pyrox. Frequently our customers send us sample lesves from treac sprayed iu May ur June tbat st ow plenty of Pyrox adhering in Oetober.

It Wom't Wash Dif. If it were not for the new growth coming along, as is usually the case with shade trees, fruit treps, shrubs, potato vines ete., and which of course must be protected, one spravine would be enough for the seasn $1 \mathrm{lb}$. 30c.; 5 lbs. \$1.00; 10 1bs. \$1.75; 25

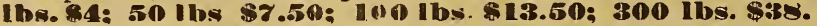

\section{INSECTICIDES}

Arsenate of Lead, 1 lb. $25 \mathrm{c} ; 5$ lbs. $\$ 1.00$

10 lbs. $\$ 2.00 ; 25$ lbs. $\$ 3.75 ; 50$ lbs. $\$ 7.00$.

Aphis Punk, per doz. $\$ 6.00 ;$ pkt. $60 \mathrm{c}$.

Black Leaf 40 , price $25 \mathrm{c}, 75 \mathrm{c}, \$ 2.50$.

Black Stuff, Tobacco Powder, per 1b. 10c.

Bordeaux Mixture, dry, per lb. 35c.

Bordeaux Mixture, liquid, qt. 50c; gal. $\$ 1.50$.

Bug Death, 1 lb. 20c; 3 lbs. 40c; 5 lbs. 65 c; $12 \frac{1}{2}$ lbs. $\$ 1.25 ; 100$ lbs. $\$ 9.50$.

Carbolinium, 1 or 2 gals. $\$ 1.35$ per gal.; 3

gals. $\$ 1.25$ gal.; 5 or 10 gals. $\$ 1.15$ gal. Cooper's Sheep Dip. pke. 50c, $\$ 2.00$.

Eureka Fumigator, $\$ 1.25$.

Eureka Weed Killer, per can, \$1.25.

Fir Tree Oil Soap, per pkg. 30c.

Fir Tree Oil, $1 / 2$ pint. $75 \mathrm{c}$ : pint, $\$ 1.00$.

Hellebore, per 1b. 50c.

Kerosene Enulsion, 45c, $\$ 1.25$.

Lambert's Death-to-Lice, 10c, 25c, 50c, $\$ 1$.

I.ondon Purple, per lb. 60c.
Nico-Fume, liquid, $\frac{1}{4}$ lb. 50c; 1 1b. $\$ 1.50$; 4 lbs. $\$ 5.50 ; 8$ lbs. $\$ 10.00$.

Nico-Fume for spraying and vaporizing. pt. cans, $\$ 2$; $1 / 2$ gal., $\$ 7 ; 1$ gal., $\$ 13.50$.

Nico-Fume Tobacco Paper for fumigating, 24 sheets, $\$ 1.00 ; 144, \$ 4.50 ; 288, \$ 8.50$.

Nicoticide, $1 / 2$ pt., $\$ 1.25$; pint, $\$ 2.50$.

Paris Green, 50c.

Pelsian Insect Powder, per 1b. $75 \mathrm{c}$.

Pyrox, 1 lb. 30c; 5 lbs. $\$ 1.25 ; 10$ lbs. $\$ 2.00$; $25 \mathrm{lbs} . \$ 5.00 ; 50$ lbs. $\$ 8.50$.

Slug Shot, 1 lb. carton 15c; 5 lb., 30c.

Sulpho Tobacco Soap, $10 \mathrm{c}$ and $20 \mathrm{c}$.

Tobacco Dust, lb., 10c.

Tobacco Soap, per pkg., 25c and $50 \mathrm{c}$.

Tobacco Stems, lb. 5c; per bale, $\$ 2.50$.

Weedicide, per gallon, $\$ 1.50$.

Whale Oil Soap, 10c, 15c, 25c.

Whale Oil Soap in bulk, per lb. $8 \mathrm{c}$.

Whale Oil Soap and Tobacco, 1 lb. 20c; 5 lbs. $75 \mathrm{c}$.

The prices on this page subject to change without notice. 


\section{SLUG SHOT}

It is a light, composite, impalpably fine

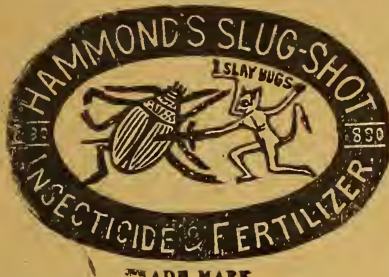
powder, easily distributed by Duster, Bellows, or "in water by spraying. It is thoroughly reliable in killing Currant Worms, Potato Bugs, $\mathrm{C}$ a b b a ge Worms, Lice, Bugs, etc., and is also strongly impregnated with fungicides.

\section{CARBOLINIUM}

Insecticide and Wood Preserver

1 gallon............................\$1.35

5 gallons (per gal.)................... 1.25

10 gallons (per gal.)................ 1.15

Special prices for larger quantities.

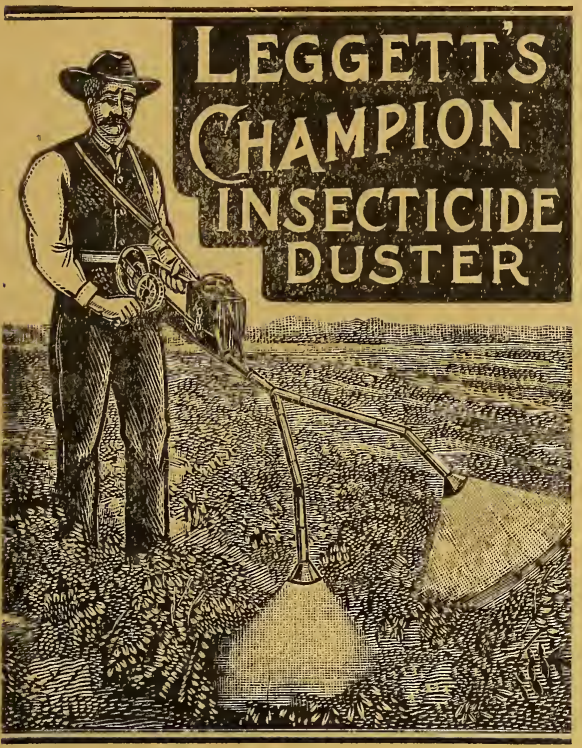

A wonderful invention. Light, swift, safe, strong and cheap. Dusts the pure green. Kills all the bugs and pests without injuring the vines or foliage. Less green used and better results obtained.

The Champion, $\$ 10.00$; Little Giant, $\$ 7.50$

\section{Remedy for Cut Worms on Cabbages and Tomatoes}

Soak bran with Paris green and scatter same in the rows. This will destroy this troublesome pest.

\section{SULPHO-TOBACCO SOAP}

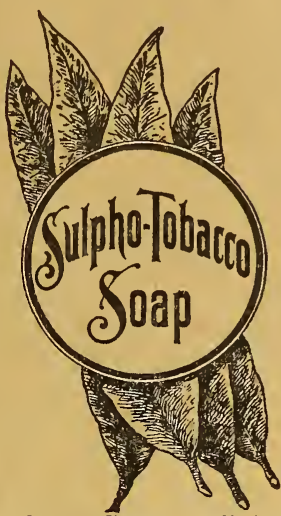

Quickly exterminates all insect life on plants or flowers in and out of doors. Unsurpassed for rose bushes. For a cheap, effective, clean and harmless Insecticide this is unexcellerl. It also acts as a valuable fertilizer reviving plant life. For domestic purposes it rids the house of cockroaches. and is a superior wash for dogs and all animals. Prevents poul. try lice. You canno afford to be without this popular and well known Insecticide, if you desire to be successful in plant culture. A trial will give highly gratifying re3-oz. Cake, sufficient for $11 / 2$ gallons prepared solution, $15 \mathrm{c}$; mailed postpaid 18c.

8-oz. Cake, sufficient for 4 gallons prepared solution, 25c; mailed postpaid $30 \mathrm{c}$.

With every order we enclose free a booklet "the Window Garden," giving valuable information of Plants, and exterminating of Insects.

\section{BUG DEATH}

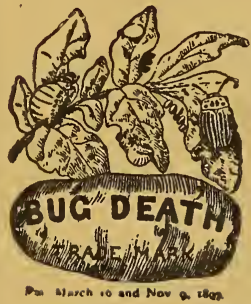

This Insecticide and Plant Food combines? has been on the marke' for ten years. While the first cost to kill the bug 4 on an acre of potatoe: is rather more than the arsenical insecticides. the extra yield of mar ketable potatoes has more than paid the en tire expense. It is non. poisonous, which make" it perfectly safe to use on all plants or vines.

BUG DEATH PREVENTS BLIGHT.

Put Up in Packages as Follows:

1 - †b. package................... .18

3 -1b. package................... 40

5 -tb. package.....................60

$12 \frac{1}{2}-$ to. package.................. 1.20 100 -th. package................... 8.00 Dickey Bug Death Duster........... . .25

\section{Arsenate of Lead (Paste)}

For Caterpillars and Chewing Insects.

For spraying trees and shrubs against leaf chewing insects, fruit flies and codling moth. Contains $15 \frac{1}{2}$ per cent Arsenic Oxide, mixes easily in water without clogging nozzle, sticks like paint, kills quick, and will not burn foliage. Dilute 1 tb. to 25 gallons.
1 tb. $\$ .25$
.5 tb. $\$ 1.10$
121 tb. $\$ 2.50$
25 tb. 4.00
50 tb. 7.50
100 tb. 13.50

To Destroy Ants in Hills, Etc.

Inject bisulphate of carbon in the hills. This will destroy them promptly. 


\section{AUTO-SPRAY NO. 1}

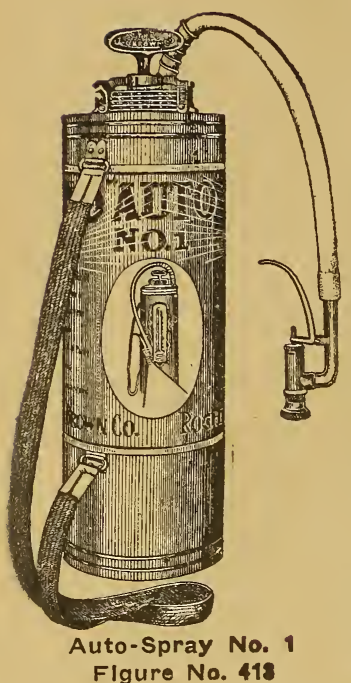

\section{Capacity About 4 Gallons}

This is the strongest and simplest compressed air sprayer on the market.

More than 300,000 are in use and it has never failed to please our trade during the years we have sold it.

It is used to spray vines, shrubs, trees, potatoes, also for applying disinfectants and whitewash in buildings.

It is made with galvanized or brass reservoir, as or. dered. (We recommend the brass because not affected by strong chemicals.)

GUARANTEE-We agree to refund purchase price to any dissatisfied customer within ten days.

\section{NET CASH PRICES}

Auto-Spray No. 1-B, brass tank..............\$8.50 Auto-Spray No. 1-D, galvanized tank............... 5.50 2 -ft. Brass Extension for trees and low down work..... .60 Brass Elbow to spray under side of leaves.......... .30 Brass Strainer for filling....................... 1.00

\section{NON-CLOG ATOMIC NOZZLE}

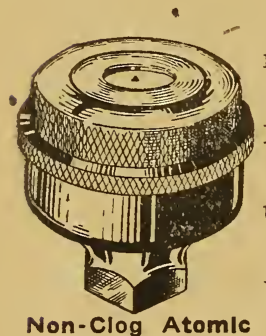

Non-Clog Atomlc
Figure No. 269

This nozzle is what its name implies. It is the only nozzle made which does not and cannot clog.

It may be adjusted for wide or narrow spread of spray and for long distance or near-by work.

We warrant this nozzle and will refund purchase price within ten days to any customer who is not more than pleased.

We repeat IT DOES NOT CLOG. One user said the NON-CLOG was worth $\$ 10.00$ to him.

PRICE-Brass, straight or 45 degrees...............\$1.00

\section{AUTO-SPRAY NO. 40}

\section{A General Purpose Sprayer}

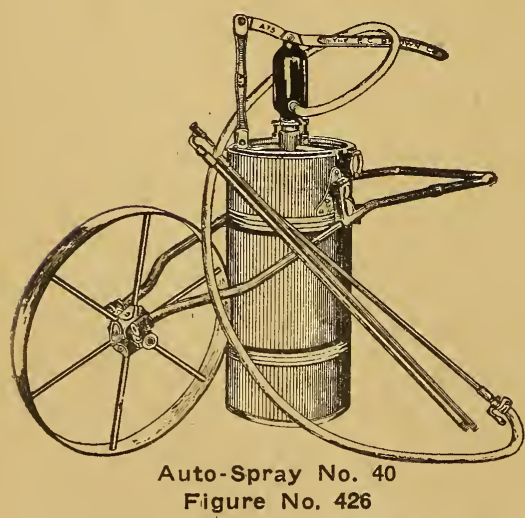

Made in two sizes, either galvanized or brass tank and with or without truck.

The pump is powerful, has brass working parts and ball valve, an ample agitator cleans suction screen in operation and mounted on truck with 20 -inch wheel, is easily portable on soft ground.

Each machine is equipped with 8 feet of $3 / 8$-inch high grade hose, 8 feet of iron extension pipe, lever shut-off and nozzle.

The Auto-Spray No. 40 is adapted to both large and small work and will spray a tree as well as the largest sprayers made. It is largely used for whitewashing and in greenhouses.

\section{PRICES}

Auto-Spray No. 40-A-Brass tank, capacity 8 gallons, no truck. . . . . . . . . . $\$ 15.00$ Auto-Spray No. 40-B-Galvanized tank, capacity 8 gallons, no truck.......... 12.00 Auto-Spray No. 40-C-Brass tank, capacity 12 gallons, with truck 20 -in. wheel ... 20.00 Auto-Spray No. 40-D-Galvanized tank, capacity 12 gals., with truck 20-in. wheel 16.00 


\section{GOULDS HAND SPRAYERS}

\section{Pomona-Standard-Monarch}
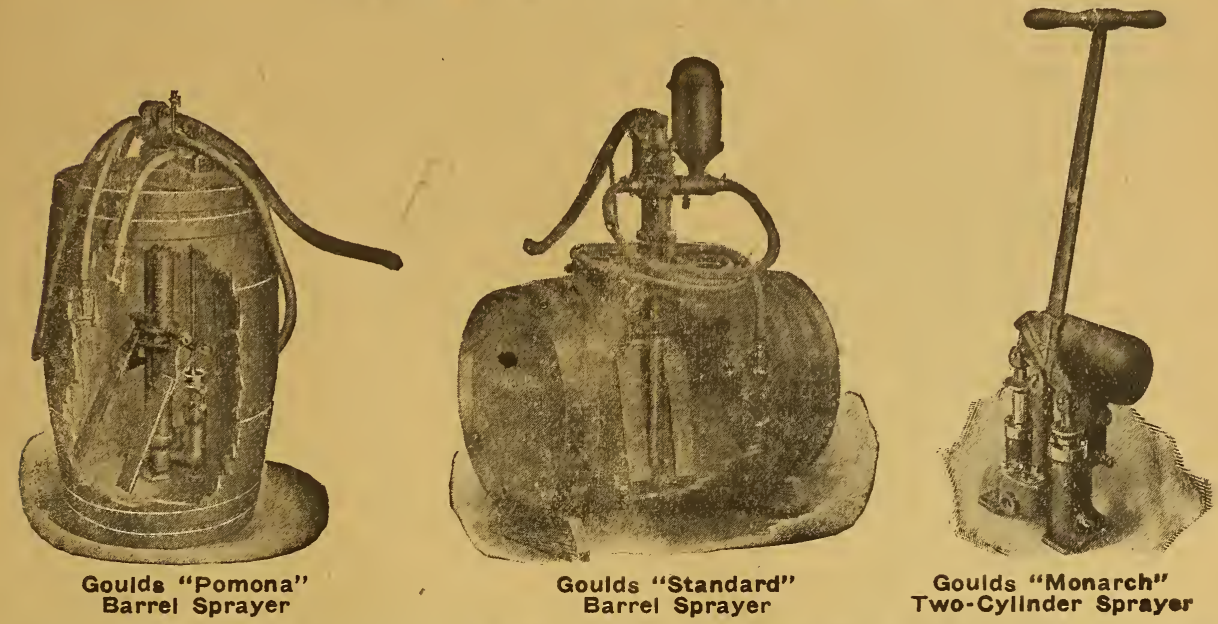

The Pomona is an extra high-grade barrel sprayer with sufficient capacity far two leads of hose and four nozzles. The plunger, plunger connecشon, gland, valves, valve seat and strainer are solid bronze and are not affected by chemicals. An agitator keeps the solution well mixed, this agitator being operated by a connection to the pump lever. The plunger is $2 \frac{1}{2}$ inches in diameter and the atroke is adjustable, 3,4 or 5 inches.

The Standard is arranged so it can be mounted on the end or side of the barrel as desired. It is made in two sizes with $2 \frac{1}{2}$ or 3 -inch cylinder. The working parts are bronze. The differential plunger gives a constant even pres. sure. Price includes brass suction strainer, but does not include suction pipe and agitator.

The Monarch is a large capacity pump for use in a wagon or on skids with the barrels of solution separate. It is useful in large orchards where a barrel sprayer is not of sufficient capacity. This pump is also widely used for whitewashing and painting.

\section{Pomona}

Pomona

Standard

Standard

Monarch

Monarch

Monarch

Monarch
With agitator and one lead 15 feet $3 / 8$-inch discharge hose with Mistry Jr. spray nozzle mounted on end of barrel.

With agitator and two leads of 15 feet each $3 / 8$-inch discharge hose with Mistry Jr. spray nozzles, mounted on end of barrel.

Fig. 905, 21/2-inch sprayer with 1-inch iron suction pipe, brass strainer, and one lead of 15 feet $3 / 8$-inch discharge hose with Mistry $\mathrm{Jr}$. spray nozzle, with Fig. 1321 agitator, mounted on end of barrel.

Fig. 1321 agitator, mounted on end of barrel. pipe, brass strainer, and two leads of 15 feet each $3 / 8$-inch discharge hose, with Mistry Jr. spray nozzles, with Fig. 1321 agitator, with air chamber, mounted on side of barrel.

2-inch cylinder, fitted with 5 feet $3 / 4$-inch suction hose with strainer, Fig. $70,23 / 8$ inches diameter and one lead $3 / 8$-inch discharge hose 15 feet long with one Mistry Jr. spray nozzle, no barrel supplied.

$21 / 2$-inch cylinder, fitted up in same manner except has 1-inch suction hose and strainer, Fig. 70, 31/4 inches diameter. No barrel supplied.

2-inch, fitted same manner with 2 leads $3 / 8$-inch discharge hose, each $15 \mathrm{ft}$. long, and two Mistry Jr. nozzles. No barrel supplied.

$21 / 2$-inch cylinder fitted in same manner except has 1 -inch suction hose and strainer, Fig. $70,31 / 4$ inches diameter. No barrel supplied.
Price $\$ 20.00$

Price $\$ 23.50$

Price $\$ 20.00$

Price $\$ 22.00$

Price $\$ 30.00$

Price $\$ 33.00$

Price $\$ 35.00$

Price $\$ 37.00$ 


\section{UNITED STATES CREAM SEPARATORS}

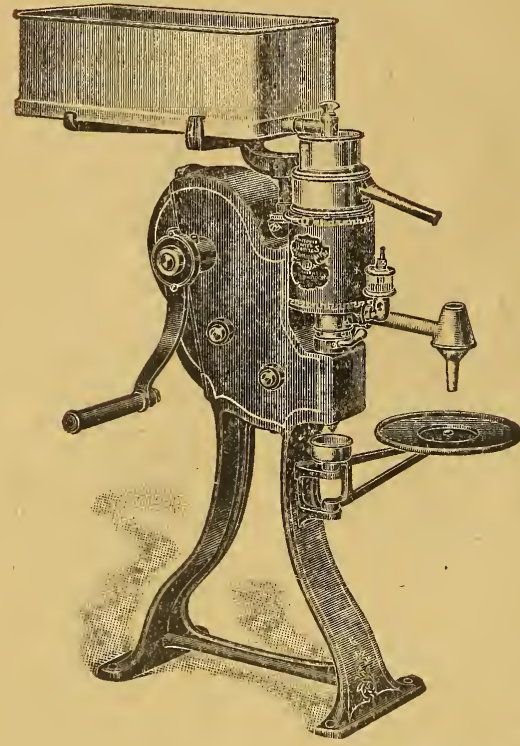

To enlarge the income from your dairy you must install modern equipment, such as the United States Cream separator.

The Interlocking U. S. Separator has NICKF:L SILVFR skimming sections which are guaranteed to never rust.

The MECHANICAL WASHER furnishes the most complete and quickest method of washing.

The U. S. Cream Separator with its improve. ments is a SANITARY MARVEL. Important new features make the BEST Separator still BETTERthe MOST PERFECT ever produced anywhere by anybody.

A great SANITARY leature is the new REMOV. ABLE LINER for bowl chamber. It is non-rusting and easy to wash. Milk, even in the smallest quantity, coming in contact with cast iron makes all other Separators unsanitary. The liner, exclusively a U. S. feature, prevents milk contact absolutely.

A new feature is the AUTOMATIC OIL CONDUCTOR which conveys fresh oil from the neck bearing to gear chamber and. with its DUTS SHIELD serves a dual purpose by keeping all foreign matter, dust, etc., from the gear chamber and lower bearing, adding years to the life of a Sepa. rator and permitting the machine to always run a. easy as when new.

A U. S. Cream Separator will make you the most money, because it skims the closest. It holds the World's Record for closest skimming in fifty consecutive runs with milk from ten different breeds of cows.

\section{Latest Interlocking Style}

No. 40, guaranteed capacity $175 \mathrm{lbs} . \$ 35.00 \quad$ No. 16 , guaranteed capacity $600 \mathrm{lbs}$. $\$ 85.00$

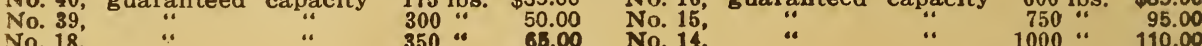

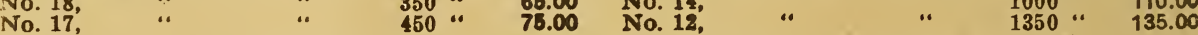

\section{Power Attachments for Dairy Sizes}

Clutch Pulley, 14 in. diam., 3 in. face, Including shaft for crank.................\$3 50

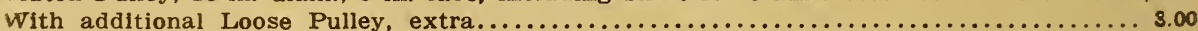
Pulleys 12 inches diameter can be supplied if desired at same prices.

separators fitted with Ratchet and Loose Pulleys 3 in. diam., 11/4 in. face, with Belt

Shifter for Worm Gear Shaft (when ordered with separator). Additional price..... 6.00 3-inch Pulleys with necessary attachments (when not ordered with separator). Prices

on application.

Sell Governing Pulley, for engine or line shaft only (give size of shaft) $\ldots \ldots \ldots \ldots \ldots 6.60$ spoed Governing Pulley, adjustable while running...........................50

\section{THE RANDOLPH GOVERNOR PULLEY}

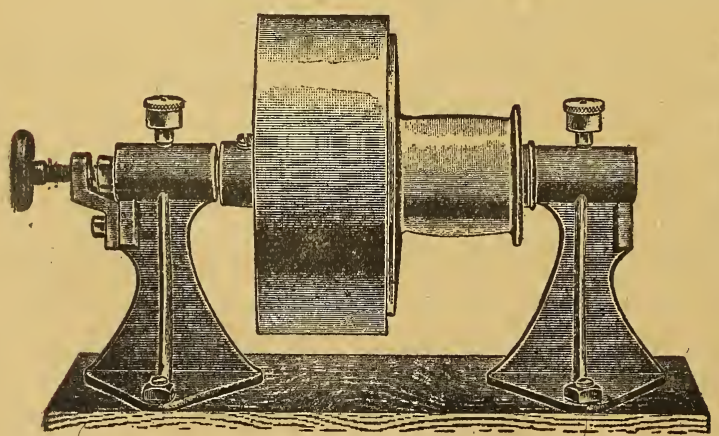

As shown in the adjoining cut absolutely governs the speed of the separator, releasing automaticaliy when the proper speed is attained and absorbing all shocks from the gasoline engine. It runs in eitlier direction without any change or adjustment. The pulley standard can be placed on the floor, side wall or overhead to suit conditions. We have embodied in the construction of 1 his pulley the loose pulley feature where. by the Separator may be stopped without stopping the engine.

Attention is called to the fact that after the proper speed has been attained by setting the jamb nuts in the hand-wheel thread the correct speed will be maintained without further notice. Price, $\$ 10.00$.

14 -inch Clutch Pulley including Shaft, $\$ 3.75$ extra. 
F. H. EBELING, SEEDS AND FARM SUPPLIES, SYRACUSE, N. Y.

\section{MILKMEN AND DAIRY SUPPLIES.}

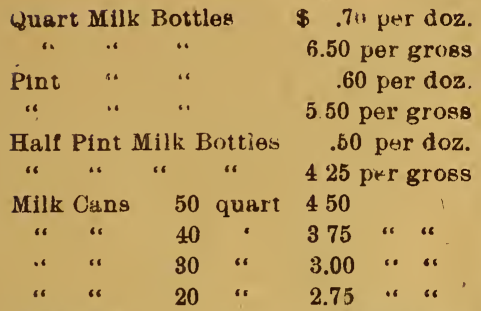

Milk Caps - - - 25 per 1000 Carrying Cans, sll sizes .50 to 2.25

\author{
Wholesale Cans, all sizes $\$ .40$ \\ Htrainer Palls " $\quad .65$ to .75 \\ Plat Dippers - - - . . .25 to .45 \\ Quart Dippers - - . .35 to 50 \\ Strainers - . - . .50 to 2.00 \\ Tin Milk Pans, per doz 1.50 to 3.00 \\ Tin Milk Pails, all sizes $\quad .30$ to .75 \\ Sprinkling Pots, “ $\quad .25$ to 1.25 \\ Excelsior Strainers - $\quad 2.50$ \\ "Our Own" Strainers - 2.50 \\ Aerutors - . - 5.00 to 7.00
}

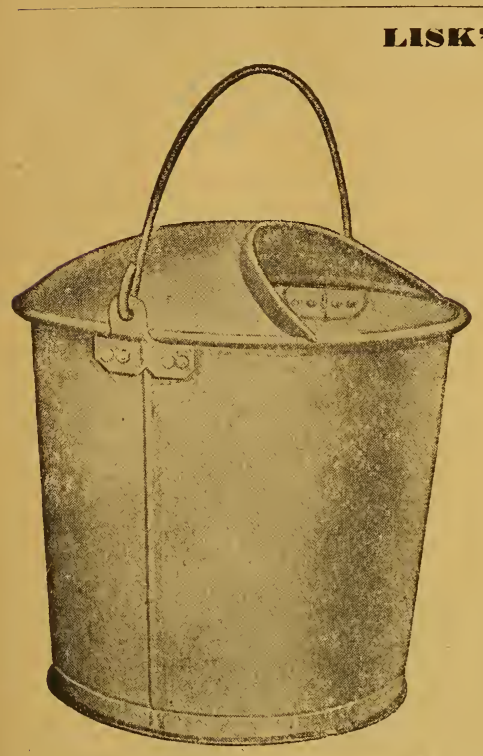

\section{HISK' SANITARY PARL}

Thi: Sanitary Pail combines nearly all of the good points that are contained in the miny kinds gut on the market in recent years, and is highly recom nended by the Boards of Health and the State Milk Inspectors. A trial will convince. Price, \$1.75.

\section{MILK FEVER OUTFIT. For Stemilized Air Treatment.}

This treatment has cured 97 per cent. all cases treated. This treatment is recommended by the Bureau of Animal Industry, United States Government, Department of Agrioulture.

The outflit consists of the instrument, a roll of tape, a package of eurbolized colton. Full directions, neatly packed. Price, $\$ 3.50$ net

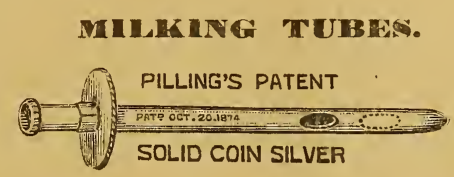

Ful] Directions with Eacb Tube. 35 cents to $\$ 1.25$ each.

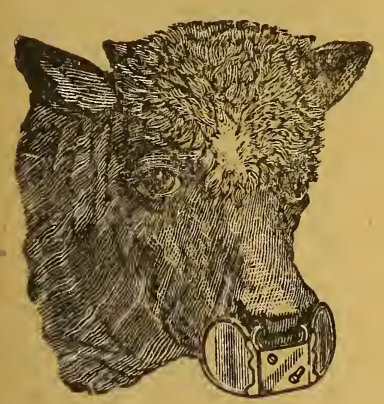

Dairy Scales $\$ 3.00$ to $\$ 3.50$

QCA AES.

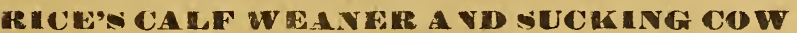 บUZZLE.}

For preventing Calves and Cows sucking themselves or each other.

No. 1-For Calves till 1 year old, $35 \mathrm{c}$, by mail postpaid $40 \mathrm{c}$ No. 2-From 1 to 2 years old, $60 \mathrm{c}$, by mail postpaid $65 c$

No. 3-For full grown animals and self suckers,

$75 \mathrm{c}$, by mail postpaid $85 \mathrm{c}$

\section{BAIRIFI, CHRUTEN.}

\section{NILK BOTTH.ES.}

1 quart, 70 cents per doz. 1 pint 60 ". ". . $1-2$ " 50 " " " " Special prise in groes lots.

\section{MILK CAPA.}

Per thousand, 45 tค 52 ets.

\section{No. $0,-4$ gallon, will churı, 2 gallons}

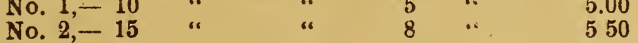

No. $3,-20$ " $\quad$ " $\quad 10$ ". $\quad 6.00$

No. $4,-25$ " -25012 " $12 \quad 7.50$

No. 5, -30 " " 14 " 14.50

Oak Dash Churns, Stone Dash Churns, Dog Powers, Butter Workers, Skimmers, Butter Carriers, Ladles, Richardson's Butter Color, Butter Print, Floating Glass Thermometers, Dairy Thermometers, Cream Gauges, Bancock Butter Tester.

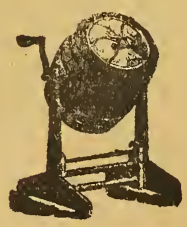




\section{CHAMPION \\ MILK COOLER FRATOR}

Automatic, Simple, Efficient, Durable.

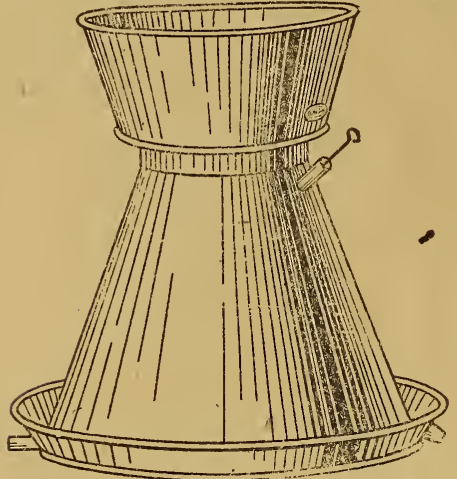

1 -10 quarts, 1 to 10 cows, 2 milkers. .\$ 7.00 2-18 quarts, 10 to 25 cows, 3 milkers.. 7.50 $3-34$ quarts, 25 to 50 cows, 5 milkers.. 8.00 4-52 quarts, 50 to 100 cows, 8 milkers.. 10.00

\section{SENSIBLE BOTTLE FILLER}

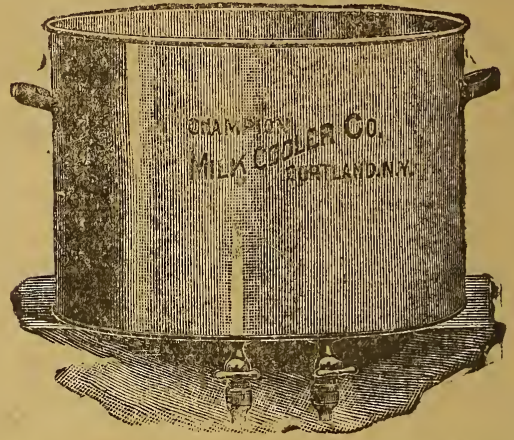

We have built the Sensible so strong and heavy that it will last a life time. You can find no more sensible way to flll your bottles. Price $\$ 4.50$.

\section{SECURITY CALF MEAL}

Security Compound is not a calf meal, does not have to be cooked or bothered with like calf meals; does not require milk like calf meals, for Security Compound is a chemical reproduction of cows' milk and takes the place of the cows' milk after the third day.

Security Compound will fatten your calf for vealing at a cost of $10 \mathrm{c}$ a day. If you sell your veal in 28 days your calf will only cost you $\$ 2.80$. The milk alone fed with calf meals cost $\$ 3.20$ for the same number of days and you have to buy the meal additional. Therefore Security Compound is cheaper than calf meals and will produce a better calf. The company's guarantee to every farmer is this: "We guarantee that you can raise as good, fat, and healthy a calf on Security Compound as on whole, fresh milk." Your money back if it does not meet this test. Price, $121 / 2 \mathrm{lb}$. package, $\$ 2.75 ; 25$ lbs., $\$ 4.25$. Special price in large lots.

\section{SA VES THE MILK}

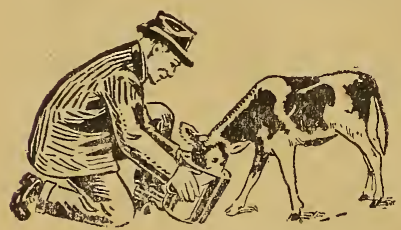

SA VES THE
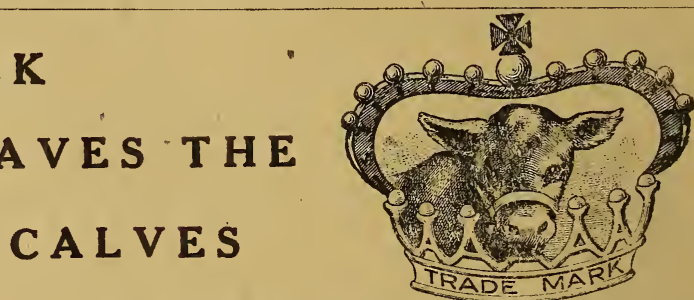

\section{SA VES YOU MONEY}
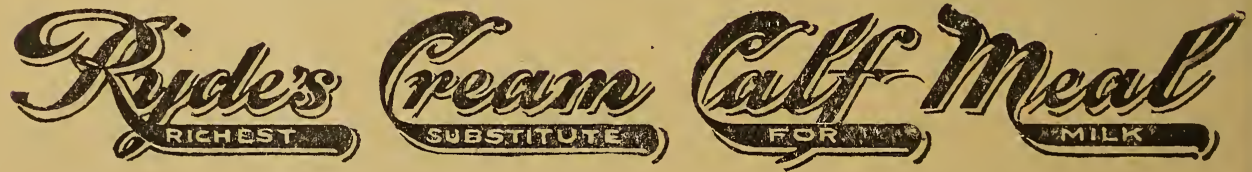

Will take the place of whole milk in either raising or vealing calves, at about one-third the cost of feeding milk. It is the only correct combination of materials to nourish calves properly with all the fibre and indigestible matter removed, thoroughly cooked and prepared for easy digestion and assimilation. Made with the care of baby food. Safe for baby calves.

Francis M. Jones of Clinton, N. Y., writes: "I can recommend Ryde's Cream Calf Meal as the best calf meal I have ever used."

THE MILK IT SAVES IS WORTH THREE TIMES ITS COST. 


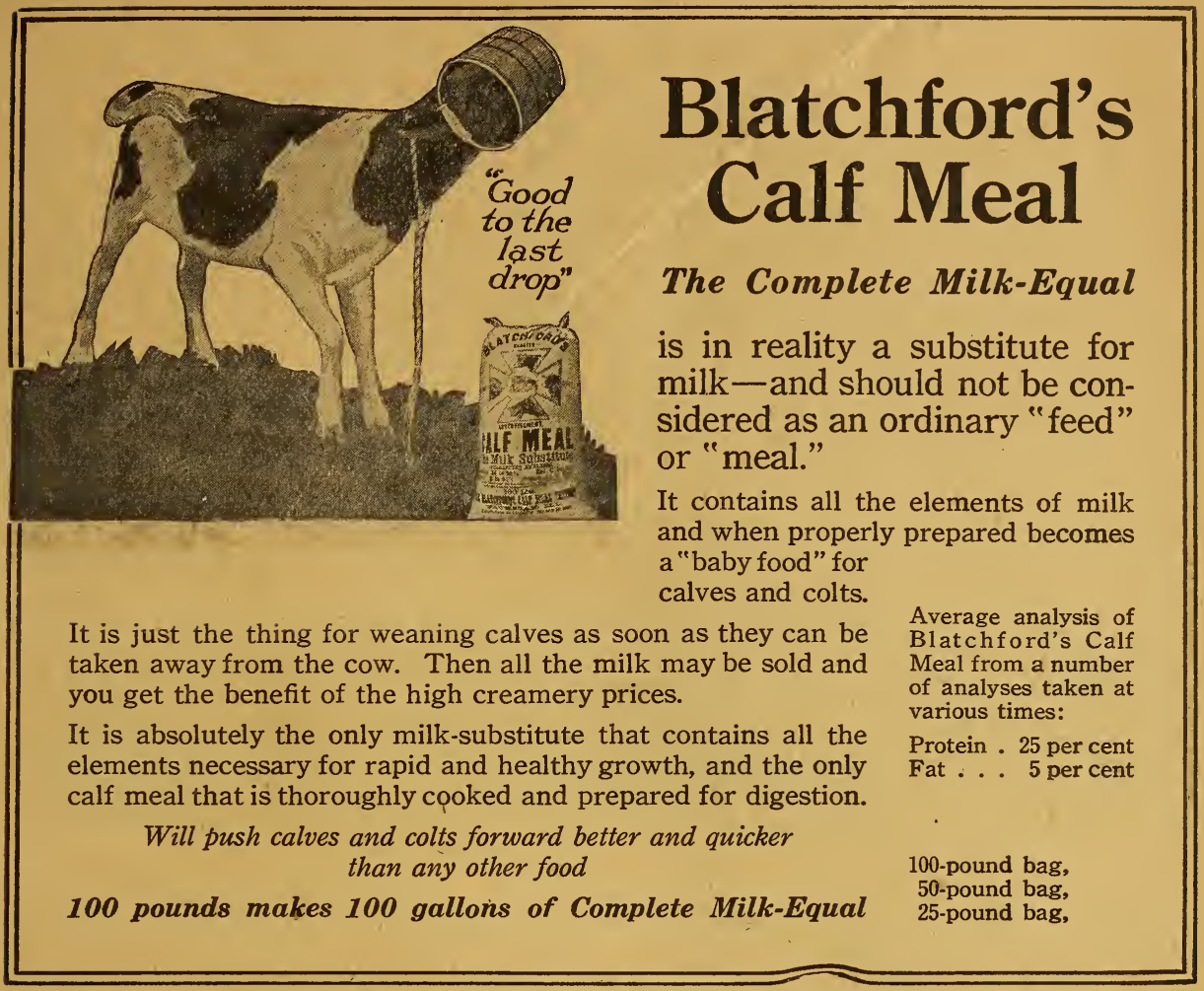

It is just the thing for weaning calves as soon as they can be taken away from the cow. Then all the milk may be sold and you get the benefit of the high creamery prices.

It is absolutely the only milk-substitute that contains all the elements necessary for rapid and healthy growth, and the only

Will push calves and colts forward better and quicker than any other food 50-pound bag, PRICES SUBJECT TO CHANGE WITHOUT NOTICE. EVERY HOG A MONEY MAKERR

Keep your hogs free from worms. These deadly pests will rob you of your profits-starve your stock-make them thin, scrawny and finally kill. If you follow the advice of the best stockmen, you will have

NO MORE LOSSES FROM WORMS

E. C. Stone, Sec. of the American Hampshire Swine Record Assn. says: "I know of nothing so good, reliable and cheap to expel worms and put hogs in condition to digest food as Sal-Vet."

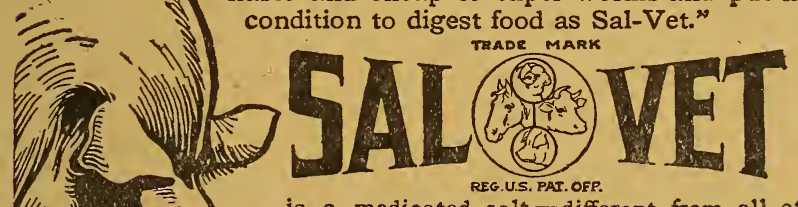

is a medicated salt - different from all other worm remedies. Safe, sure to kill worms, tones up your stock, helps turn food into fat and flesh quickly

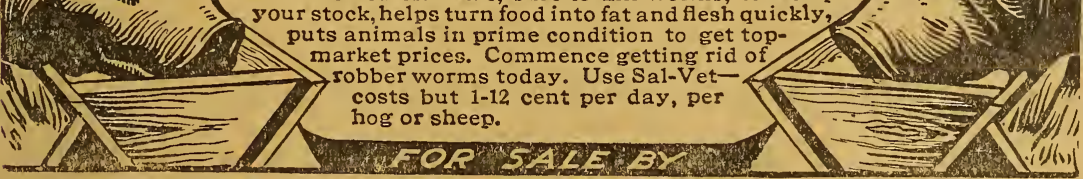

\section{F. H. Ebeling}

Each 10 to. drum................ .75

Each 20 to. drum................ 1.25

Each 40 to. drum................... 2.25
Each 100 tb. keg...................... 5

Each 200 to. bb1........................ 9.00 Each 300 tb. bbl.......................... 13.00 


\section{HE JAMES WAY}

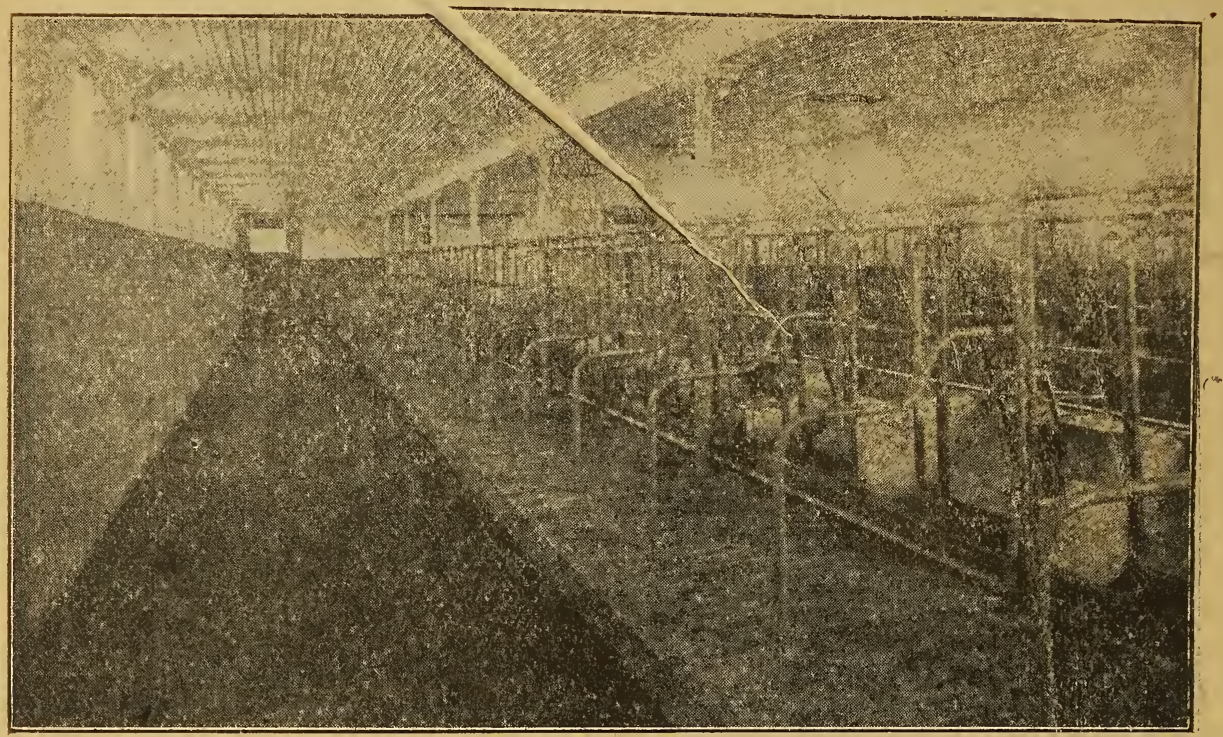

SYRACUSE UNIVERSITY BARN AND STABLES

The above photograph shows one of the buildings connected with the Syracuse University College of Agriculture, and which contains the celebrated

\section{JAMES STANCHIONS, STALLS AND LITTER CARRIERS}

The following is a partial list of users of the celebrated James Sanitary Barn Equipment:

George Ferguson, North Syracuse, N. Y.

Stevens Bros. Co., Liverpool, N. Y., Holstein breeders.

H. M. Dunham \& Son, Marcellus, N. Y., Holstein breeders.

J. A. Stanton \& Son, New Woodstock, N. Y., Holstein breeders.

F. M. Jones, Clinton, N. Y., Holstein breeder.

E. H. Dollar Est., Heuvelton, N. Y., Holstein breeders.

Borden's Condensed Milk Co., certified plants at Earrville, Edmeston. Walkill.

J. H. Gallup, Syracuse, N. Y. certified .

Alfred Ferguson, North Syracuse, N. Y. Henry Carhart, Minoa, N. Y.

A. L. Brockway, Syracuse, N. Y. $\quad$ Greiner Bros., East Syracuse, N. Y.

Carl Amos, Syracuse, N. Y. A. J. Helfer, Minoa, N. Y.

W. R. Percival, Syracuse, N. Y. John Arfman, Middletown, N. Y.

John Craig, Solvay, N. Y. Sharpless Separator Co.

Mohawk Condensed Milk Co., and many others.

\section{THE JAMES STALLS AND STANCHIONS}

The man who depends on his cows for his living, must take advantage of every opportunity to save the time of his hired help and his own time; to prevent waste of feed; to avoid disease of all kinds; and he must use every proper means of increasing the yield of milk, and of getting a bigger price for his product.

James Equipment is designed specifically to meet every one of these needs. It keeps cows cleaner; saves labor, time and feed, all of which cost money; aids in preventing and curing tuberculosis and other diseases; prevents accidents that might cause abortion or ruined udders; increases the yield of milk, by making the cow almost as comfortable as in the open pasture; and the equipment, if you sell milk direct to the housewives, can ofttimes be used in such a way as to get more customers and a bigger price per quart.

At the same time, the equipment presents such a handsome appearance in the barn, that nothing better could be wanted in any stable, however fine.

Unitil the James Equipment was invented, stalls and stanchions were merely means of tying cows.

James Stalls and Stanchions tie the cows, all right-tie them so they can't get loose until they are turned loose-but the James Stalls and Stanchions are far more than mere cow ties.

Important as it is that the cows be tied securely, there are a dozen other ways in which the James stalls are of equal value.

The saving effected by the James Equipment amounts to as much in a year as the cost of the equipment itself; it is the biggest moneymaker on the dairy farm, and you are losing big profits every day you do without it.

FOR PRICES SEND FOR LARGE CATALOG 


\section{THE J A M S W A Y \\ James Watering Buckets}

Bvery dairyman now realizes that regardless of how well the cow may be fed and cared for in every other way, the maximum yield of milk cannot be secured unless she has plenty of water. The old way of watering once a day out in the yard is the most expensive that could be devised. The cows become very thirsty, and drinking excessively of cold water, become chilled, and are forced to use up energy getting warm that should have been used in making milk. But the increase of milk yield is not the only advantage. There is also the saving of time and labor of the attendants, and, as compared with other methods of watering in the barn, a saving of water. More important is the prevention of the spreading of contagious diseases through the water, for with the James Watering Buckets each cow is furnished pure, fresh water, direct from the protected supply tank.

\section{THE JAMES CARRIERS}

James Carriers are "long life" carriers-built to stand the strain and wear of yearemade to forestall breakages and repairs-made to save the maximum of work and time. We are proud of them, believing that each is the best that can be built to meet the specific purposes for which it is designed. And in this belief, we are backed up by hundreds of enthusiastic, commendatory letters.

\section{The James Ventilator}

The James Ventilator is absolutely storm proofneither snow nor rain can enter; nor can birds get in, all openings being covered with galvanized bird prool netting.

The James Ventilator with the open base, ventilates the haymow as well as the stable.

\section{Can't Afford It}

One of the most powerful of all evil influences affecting the cause of good farming is the state of mind in the farmer that is constantly saying "I can't afford it." It begets a state of unbelief in better things, better methods, better cattle, and all kinds of farm stock, better buildings and better homes.

Before a farmer can take the first step towards improvement he has to overcome this ghost that is constantly before his eyes, "I can't afford it." $\mathrm{He}$ never sees the real truth behind that delusion which is, that he cannot afford to do anything except in a most thorough and painstaking manner.

"CAN'T AFFORD IT" has kept thousands of

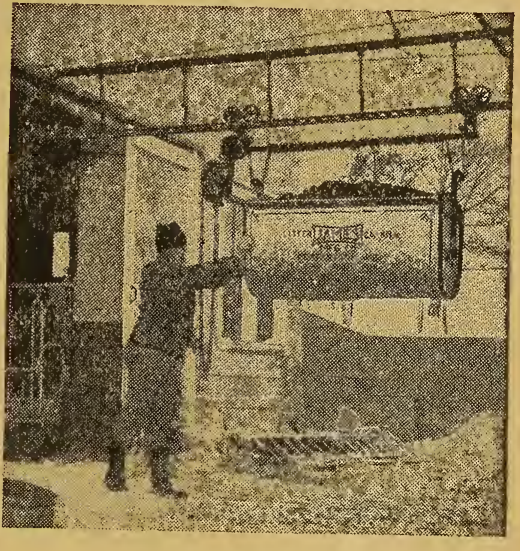

The James Way farmers with their noses down to the hard grindstone of bad, wasteful methods; poor, unprofitable live stock; bad methods of soil cultivation. In short, it is the spirit that is OPPOSED to more than it is in favor of. AND IN THAT SPIRIT NO FARMER EVER DID GO AHEAD."-From Hoard's Dairyman.

\section{BIG ILLUSTRATED CATALOG}

"The James Way" (Catalog No. 20) is a handsomely illustrated book of 256 pages, giving complete information regarding James Sanitary Barn Equipment and showing how to build and equip a practical, up-to-date dairy barn.

If you have any intention of building a dairy bárn, or remodeling, or even rearranging, you should write at once for a FREE copy.

This book will give you information regarding the fundamentals in barn construction; the construction of plank frame barns; the King system of ventilation and its installation; the proper width and arrangement of barns; lighting; stable floors and their construction; information regarding site, size, appearance, design, drainage and equipment, together with a number of barn plans and other information of interest to dairymen who intend to build new barns or remodel old ones.

The information contained in this book has enabled many local dairymen to save money in the building of their barns and in operating the plant after the barn was completed.

The book has cost considerable money to publish, but we will send it free, postpaid, te any dairy farmer who intends to build a barn. 


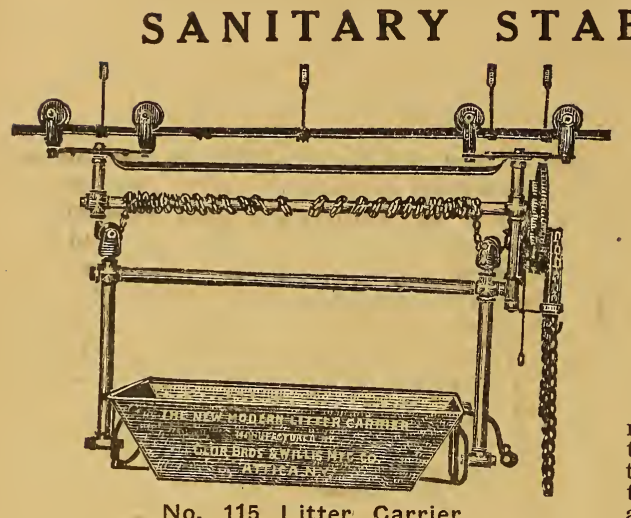

F I X T U R E S

NEW MODERN

\section{LITTER AND FEED CARRIERS}

\section{Single and Double Trolleys}

\section{Crank or Chain Hoist}

Strongest and easiest running Carrier made. The most practical and up-to-date time and labor saver on the market. Carries the litter away from the stable and saves you three-fourths the expense. Pays for itself in a short time.

\section{THE ,NEW MODERN WATERING SYSTEM}

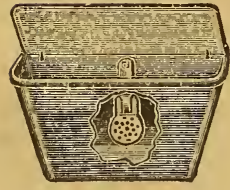

No. 410

This Watering Basin with our system will furnish a cow with fresh water at any time. This means an increase of from 5 to 10 per cent in the flow of milk. The basins are cast iron thoroughly coated, round corners smooth bottom. Inlet on the back side tapped for $3 / 4-$ inch pipe. Covered with strainer, hinged so that the particles of chaff can be easily removed. Hardwood back board included with each basin. No. 1, price $\$ 1.50$; No. 2 , price $\$ 1.75$.

Galvanized iron covers, practical and sanitary. Cattle soon learn to raise the covers themselves. The drop is automatic. Price $35 \mathrm{c}$ and $50 \mathrm{c}$.

\section{NEW MODERN SANITARY STEEL STALLS}

Steel or Wood Stanchions, Chain or Pivot hung; Manger Partitions, Guard Rails, Name Plates, Feed Mangers, Hay Racks, Hog Troughs, Tanks, Box Stalls, Calf Pens, Piggeries, Square End Guards, Adjustable Steel Gates, Horse Stall Guards, Salt Bricks, Cork Floors and Ventilating Systems complete.

Litter Carrier No, 115, Double Trolleys, Chain Hoist, Capacity $700^{\circ}$ to

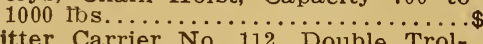
Ensilage Carrier No. 113,25 bushel Capacity, Double Trolleys...........

Platform Carrier No. 114, Double Trolleys, Crank Hoist................

Platform Carrier No. 114, Double Trol-

Track including Hangers every 28

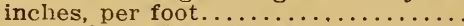
Curves including Hangers every id

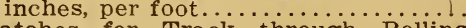
Latches for Track through Rolling

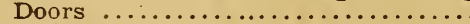

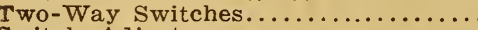

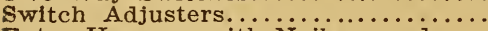
Extra Hangers with Nails, per doz.. 5/16 inch, 7 Wire Strand, per foot... Stall No. 300 Double Standard, Steel Frame

Stall No. 310, Single Standard, Steel

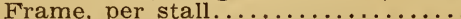

Stall No. 330 , Wood Standards and Top, Angle Iron and Sockets........

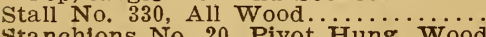
Stanchions No. 20, Pivot Hung, Wood stanchion No. 25. Chain Hü.... Wo... Wod

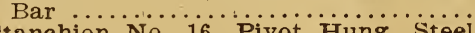
Stanchion No. 16, Pivot Hung, Steel Wood Lined Bar.................... tranchion Nn. '15, Chain Hung, Steel

\author{
45.00
}

37.50

40.00

37.50

45.00

.25

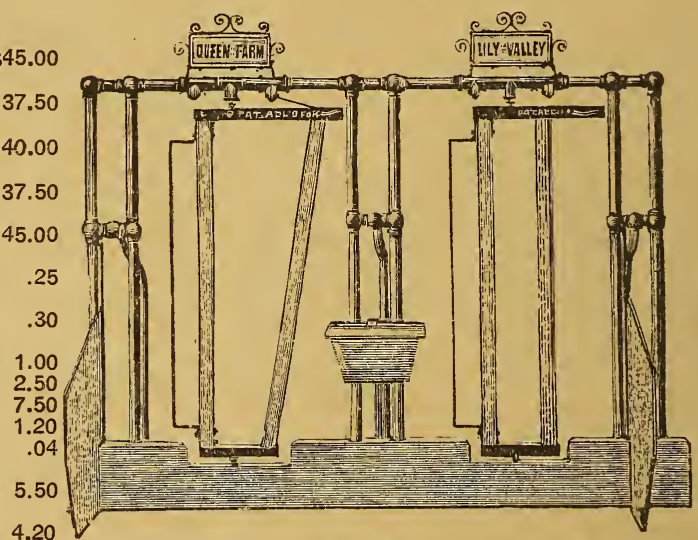

No. 300

2.25

\section{We Equip Stables Completely}

All of our goods are made of the very best of material by workmen who take a pride in their work. With ordinary usage they will last a lifetime. 


\section{WHEELBARROW SEEDERS}

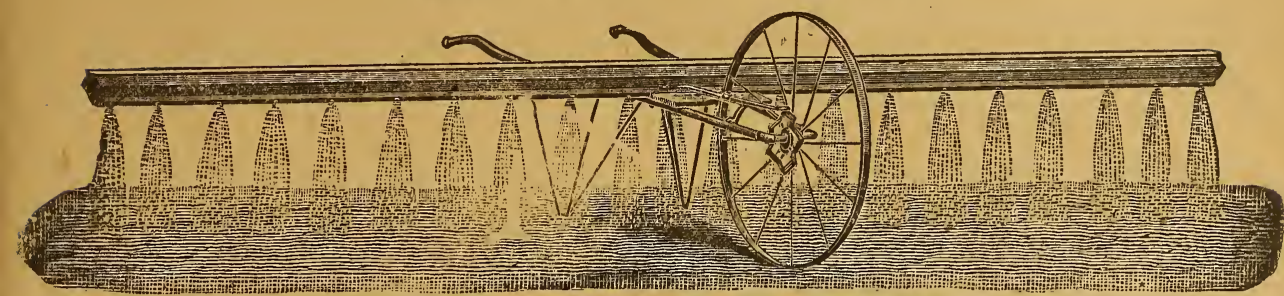

WITH WOOD OR IMON FRAMIE.

They can be worked by anyone who can run a wheelbarrow, Price, 14-foot, $\$ 7.00 ; 16$-foot, $\$ 8.00$.

\section{THE LITTLE GIANT SEED SOWER}

This is the oheapest Crank Seeder on the market, and - qual to the best for quality of work it does and durability. Don't pay $\$ 5.00$ for a seeder when you can get its equal for lass money.

Will sow Wheat, Oats, Rice, Flax, Millet, Turnip Seed, Olover Seed, Grass Seed, inoluding Light grasses; in fact any kind of Beed broadcast. Also Plaster, Fertilizer, Salt, Ashos, ote.

They save one-third seed and two-thirds labor.

\begin{tabular}{l} 
CRANK SEEDERS \\
FIDDLE SEEDERS $\quad-\quad-\quad-\quad \$ 2.25$ \\
\hline
\end{tabular}

THE "REX" RIVETER

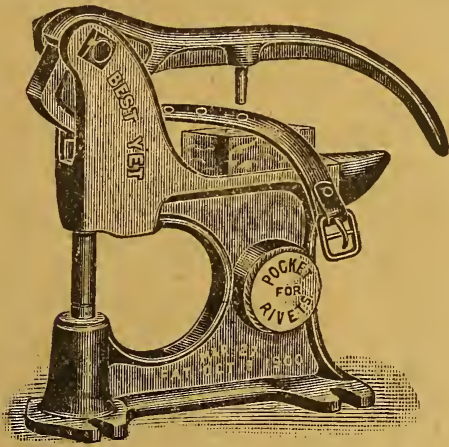

THE HEST.

The chespest, most durable and the most Practical Riveting Machine on the market. Price 750 and 1.00

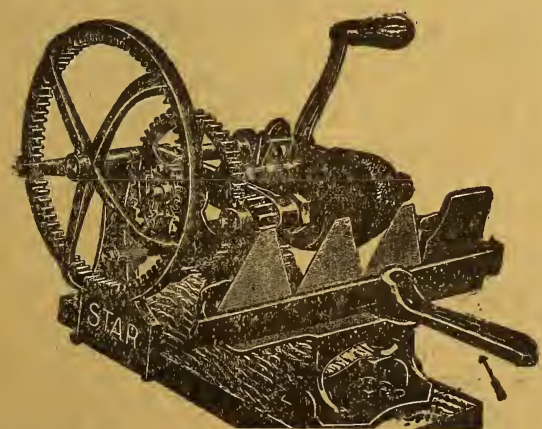

STAR SICKLE GRINDER, \$5.00

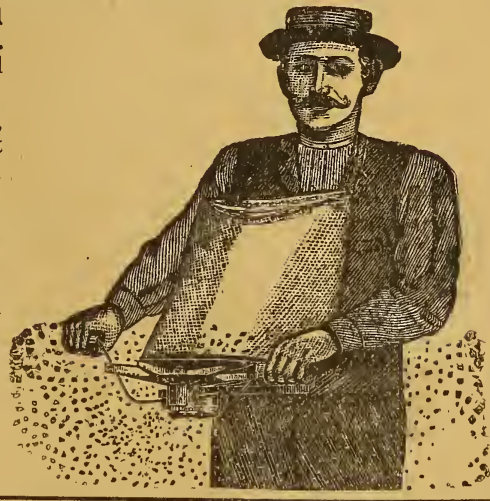

Eureka ${ }^{\text {Kitchen Garden }}$ and Hot Bed Drill

It will sow and cover Beets, Cabbage, Oarrots, Celery, Lettuce, Onions, Radishes, Spinach, Tur. nips, and all such seods with the greatest regularity. Force Feed. It is only intended for small Gardens and Hot Houses.

Sows up close to the sides in straight rows. Sows the small packet of seed as well as a larger bulk. This Drili is not a toy, but a strong, practical machine that will last many yei.s. P

$\mathbf{R}$

I

\section{$\$ 1.50$}

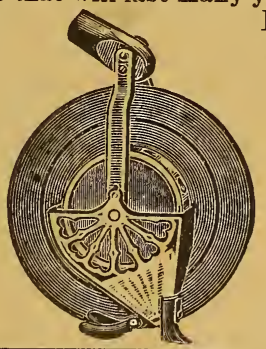

D. S C 0 $\mathbf{U}$

TO THE TRADE

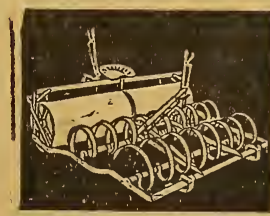

Imboden's Harrow on tree tria without money in advance. Ro turn at our expense if it does no please you. Fixtures to use Harrow and Roller separate and to make a riding cultivator. Guaranteed combined to give $50 \mathrm{per}$ cent. better and nicer seed bed in half the time. Field looks like garden, no foot prints are left. Can see check marks easier. Saves 1 team, and no heavier draft. boy can do the work and ride. Operate teeth any depth, is ready in a second to raove. Hundreds of them in use since 1900 . Jus sk for reports, description, price and terms.

Sold by F. H. EBELING.

Price \$38.00. 


\section{SYRACUSE CHILLED PLOWS}

These Plows are so well known that no word of introduction is necessary. We are pleased to offer their full line to our farmers at the usual prices.

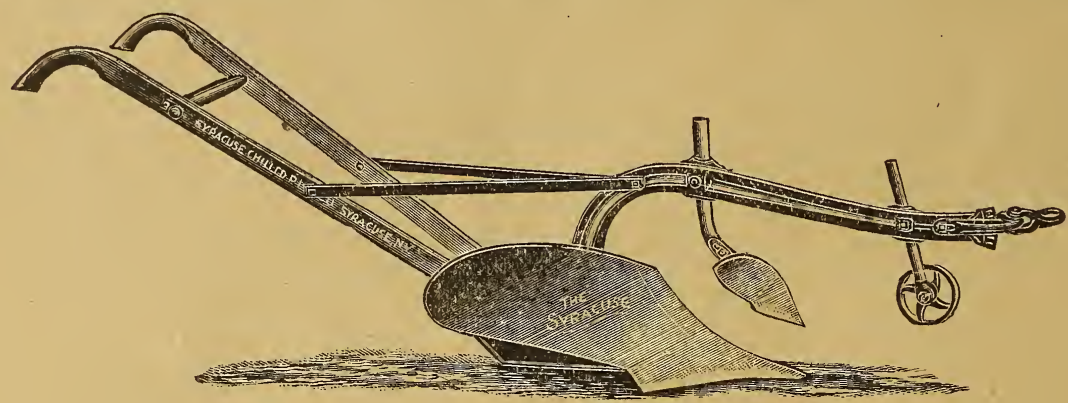

\section{Syracuse Steel Beam Chilled Plow}

Made in three sizes, No. 401, No. 402 and No. 403

Chilled Wearing Parts, Light, Strong, Durable

No. 403-Light Two-Horse, furrow 4 to 6 inches deep, 9 to 12 inches wide. . . \$16.25 No. 402-Medium Two-Horse, furrow 5 to 7 inches deep, 11 to 14 inches wide..... 16.75 No. 401-Large Two-Horse, furrow 5 to 8 inches deep, 12 to 15 inches wide..... 17.25 No. 31-Large Two-Horse, furrow 5 to 8 inches deep, 12 to 15 inches wide...... 20.25 No. 32-Large Two-Horse, furrow 5 to 8 inches desp, 12 to 15 inches wide...... 19.75 No. 61 -Large Two-Horse, furrow 5 to 8 inches deep, 12 to 15 inches wide...... 19.25 No. 62-Large Two-Horse, furrow 5 to 8 inches deep, 12 to 15 inches wide....... 18.75 No. 31-39-Reversible Sulky, 3-horse hitch......................... 75.00

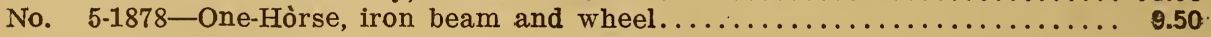

\section{MUNNSVILLE PLOWS}

\section{No. 10, All Steel Plow-“The Big Seller"}

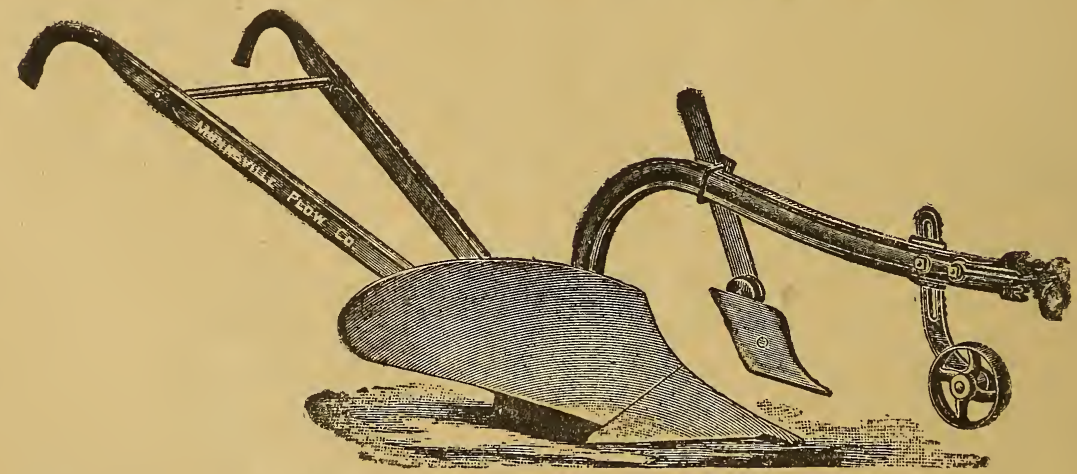

This Plow is long on the run with a high moldboard, of a shape that insures easy draft, good cleaning qualities and pleasing appearance. Price $\$ 18.50$.

Munnsville No. 46-Chilled Plow, $\$ 17.00$.

Munnsville No. 7-One-horse Plow, $\$ 14.00$.

\section{ONEIDA VALLEY CLIPPER NO. $21 / 2$}

A light one-horse cast steel Plow, adapted to plowing out corn, hops and nurseries. Can be gauged so as to plow to and from the rows.

Price, $\$ 13.50$ Plain. No. $21 / 2$ Chilled, $\$ 14.00$. 


\section{Dutton Steel and Chilled Plows}

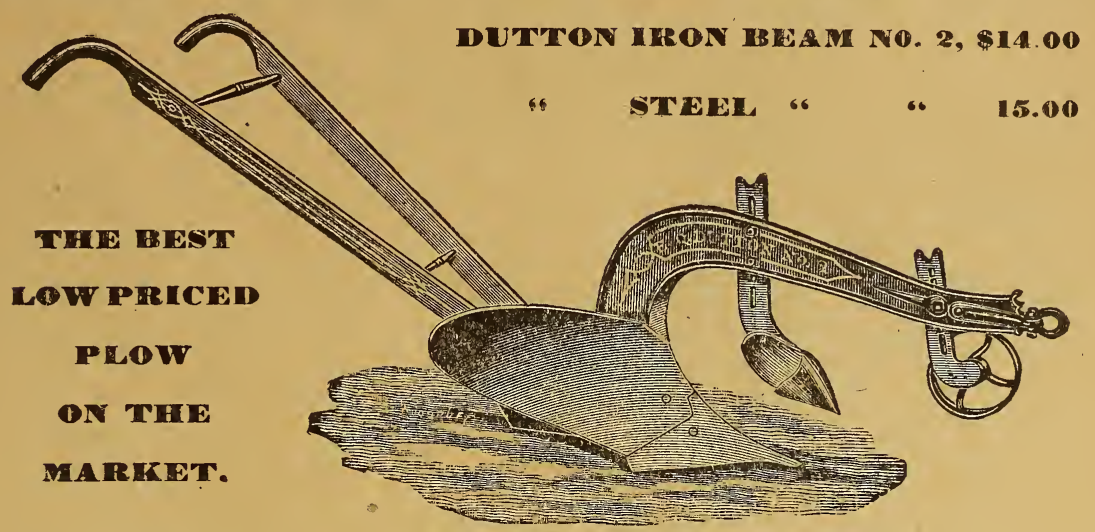

\section{DITCHING PLOWS, PRICE \$10.00}

\section{DEERE CORN PLANTER}

A Corn Planter is absolutely worthless unless it will plant your corn accurately. The John Deere No. 999 will do this: Field trials and tests under varying conditions have proven conclusively that the John Deere No. 999 Planter is the most perfect variable drop Corn Planter made. The variable drop consists of a train of gears constantly in mesh whereby two or three kernels can be planted, as desired, by merely shifting the foot lever. The John Deere No. 999 is a full variable drop Planter both for hilling and drilling, as it also varies the distance in drilling, giving a greater variety of distances than the ordinary planter without the use of extra sprockets and plates. A very simple and highly efficient machine. Complete with Fertilizer Attachment. Price $\$ 65.00$.

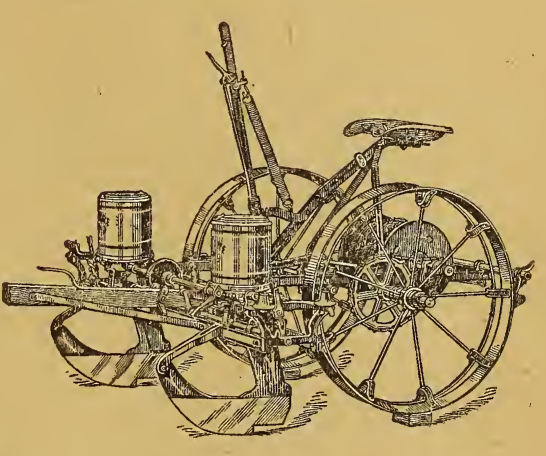

\section{Bargains in Tools and Implements}

We offer at an especially low price the following list of tools and implementsevery one of which is a genuine bargain and can be seen at our warehouse. Some of these have been somewhat used.

1 Sterling S. D. Rake.

4 Bullard Hay Tedders.

1 14-16 Adriance Disc Harrow

1 Ridging Roller.

1 Darnell Furrower and Marker.

1 Webber Fanning Mill.

1 2-horse Gas Engine, vertical.

1 3-horse Gas Engine.

2 Emerson Low Down Manure Spreaders.

2 11-7 Empire Drill, somewhat used.

1 Comb. Roller and Harrow
1 Covered Cutter.

1 Top Buggy.

1 Family Carriage.

1 Keystone Weeder.

1 Standard S. T. Harrow, 15 tooth.

1 Gal. 60-tooth Peg Harrow.

Also Bargains in 20th Century Low-Down Manure Spreader and Emerson Manure Spreader, and Lumber Wagons.

1 4-horse Gas Engine-

1 6-horse Gas Engine.

All new and in good condition.

All new at a special price.

1 Second-hand Low-down 20th Cen-

1 20th Century Spreader. Price $\$ 25.00$. tury Spreader. Price $\$ 50.00$.

Both in working order. 


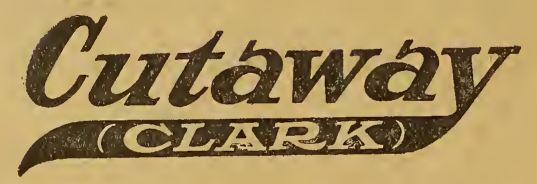

\section{DOUBLE ACTION DISC HARROW}

The farmer who realizes the importance of stirring and pulverizing the soil so that the sun and air and moisture can reach every particle is the man to whom the CUTAWAY (CLARK) Double Action-the original double action-means something more than just a disk harrow. No other disk harrow of any make or style even approaches the CUTAWAY (CLARK) Double Action for pulverizing the soil, for saving time, for saving horses, for giving long service. Its superiority for pulverizing the soil and giving long service has seldom been questioned.

The rigid main frame is the all-important feature in any double acting harrow. This frame holds the rear gangs so that the rear disks cannot slew to the furrows cut by the fore disks, but instead cut midway between where the fore disks have cut, thereby making the machine pulverize every inch of the soil to the full depth to which the disks run.

The distance from the hitch to the extreme rear end of the harrow is but a little more than one-half of that on the tandem or trailing harrows, which fact makes the draft from 25 to 50 per cent less than in other harrows of corresponding size. By the elimination of the tongue truck we save the buyer from $\$ 4.00$ to $\$ 5.00$. The oil-soaked hardwood bearings are encased in a new dustproof boxing, the most perfect yet designed for disk harrows. The lubrication is done through the standard, the oil dropping directly on top of the bearing spool inside of the bearing. The disks are cutlery steel forged sharp.

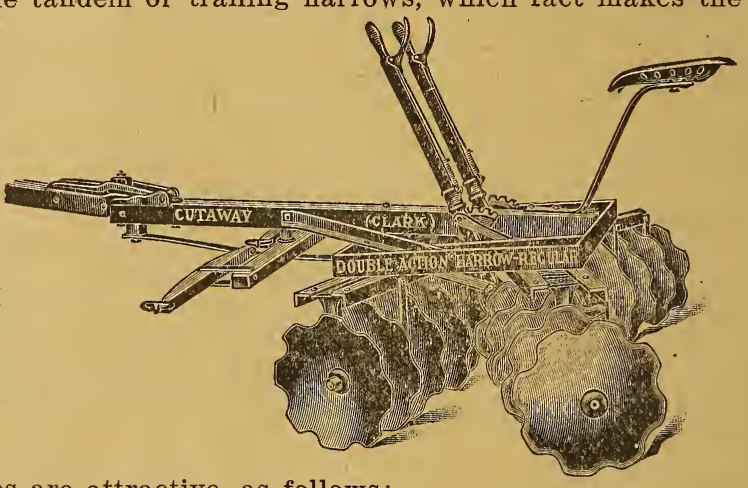

In addition to this, the prices are attractive, as follows:

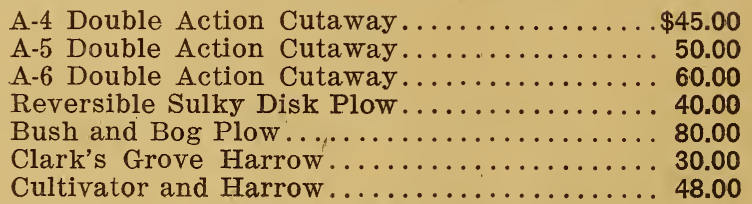

The CUTAWAY HARROW COMPANY was the first to design a disk harrow to meet the particular requirements of tractor use. This harrow has been on the market as a perfectly working tool for more years than any other Engine Harrow. There is no horse harrow built which will give satisfactory and lasting service with a tractor. In the development of a special harrow for tractor use has been its success.

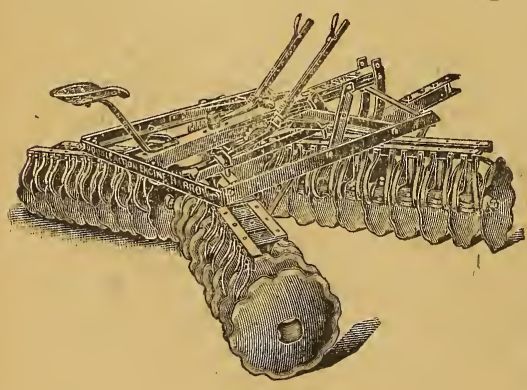

The general design of these tractor harrows is shown in the illustration at the left. They are made in all sizes, cutting fram $4 \frac{1}{2}$ to $121 / 2$ feet wide; and for tractors delivering from five to fifty horsepower. Any farmer who owns or expects to buy a tractor owes it to himself to let us tell him more about these CUTAWAY (CLARK) Tractor Harrows if he wants to make the best use of his power.

Ask us for special folders describing these CUTAWAY (CLARK) Disk Implements. The book, "The Soil and Its Tillage," free on request at our store. 
F. H. EBELING, SEEDS AND FARM SUPPLIES, SYRACUSE, N. Y. THE KEYSTONE ADJUSTABLE 。

\section{FLAT-TOOTH WEEDER}

\section{(The Keystone Adjustable Flat-Tooth Weeder narrowed to 30 inches.)}

This is the most useful and practical Weeder of the many Weeders on the market. Every gardener and farmer should have one.

Weight, 97 Pounds

Price $\$ 16.00$

Can be expanded to $7 \frac{1}{2}$ feet if desired.

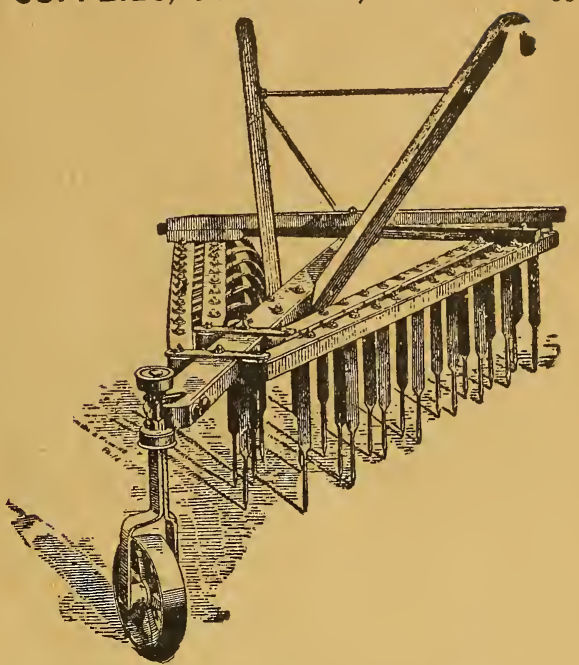

\section{ACME PULVERIZING HARROW AND CULTIVATOR}

\section{STANDARD 2-ROW \\ RIDING HARROW}

Lightest Riding Harrow sold anywhere. Low in price, light in draft, most easily handled.

Cuts, crushes, turns, smooths and levels, all in one operation.

$6 \mathrm{ft} .6$ in. Two Horse Size:

PRICE $\$ 16.00$

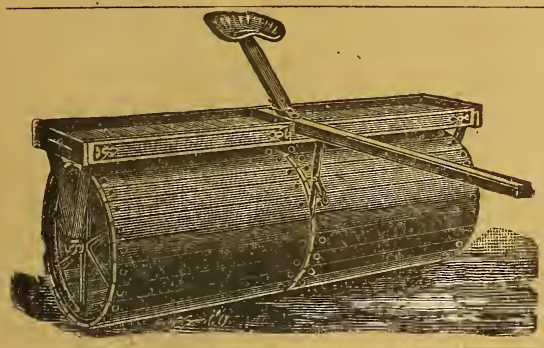

\section{LAND ROLLERS}

Oak Stave Roller, two sections...... $\$ 25.00$ Steel Roller, 26 inch, two sections, with

closed ends................ \$28.00

Lawn and Garden Roller... \$ $\$ 10.00$ to $\$ 15.00$

These Rollers are made of the best material and made near home. All parts can be easily supplied.

\section{RIDGING ROLLER}

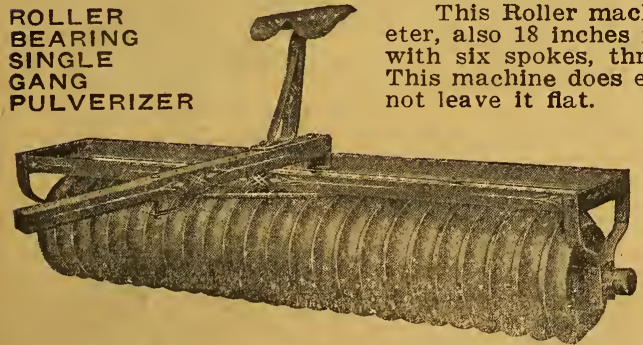

packing and pulverizing the ground-keeping th 7 -foot Roller, 15 -inch......... \$33.00 8 -foot Roller, 15-inch.......... 37.50 


\section{HAY CAPS-Insurance Against Wet Weather}

The value of keeping your hay dry, and especially, Alfalfa was sharply emphasized during the past season of excessive rains, owing to the heavy losses suffered by our Alfalfa growers in this county, and which han up into many thousands of dollars; also proving to be a heavy annual loss due to uncertain weather conditions. To illustrate how such losses can be controlled, we need only to refer to the methods employed by Chancellor Day on his University Farms. When it became apparent that heroic measures must be used, the Chancellor made use of some five hundred hay caps which we ordered by express. This quick action saved the University from a heavy loss and all of their hay was saved without any damage to the Alfalfa, and which cured perfectly under this cover. But for the Chancellor's characteristic energy and promptness it would have proven a serious loss.

One of the questions often asked is how to fasten the corners down, and everyone has their own ideas on this. One way is to use pegs attached to the eyelets in the corners of the Caps, another simple way is to tie stones, brick or gravel in a piece of burlap or rag, of sufficient weight to hold corners down and tie to the eyelets, others again have suggested a lead weight sewed in each corner. It is better for this to be done on the farm, as when shipping, it adds to the cost of freight to have so much extra weight.

We offer the best quality and other grades at market prices.

\section{NATIONAL FIRE PROOFING COMPANY NATCO IMPERISHABLE SILO}

(Patented)

Here's the new type of silo-the silo that has raised the standard of quality of ensilage for feeding. The silo whose walls are moisture proof and air tight and consequently keep ensilage from becoming sour, moldy or rotten.

THE NATCO IMPERISHABLE SILO is built of hollow vitrified-clay tile, reinforced by two continuous steel bands between each layer of blocks. There are no staves to warp, shrink or split. No hoops to tighten. No continual repair bills. Never needs painting. The Natco Imperishable Silo is Weatherproof, Decayproof, Fire-resisting.

It will last a lifetime and the first cost is practically the last cost. It can be erected by any mason as easily as a carpenter builds the old type of silo. When completed you have a very attractive as well as an efficient and durable silo added to your permanent farm building assets.

WRITE FOR FREE SILO BOOK.

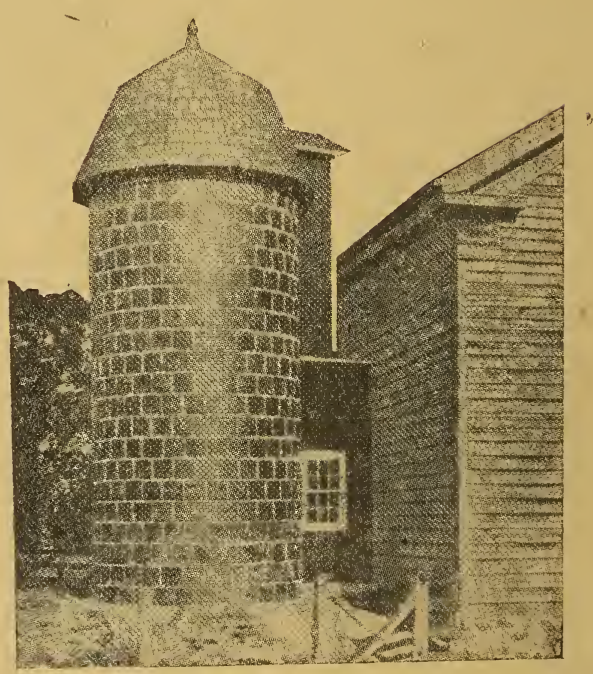

Hollow Tile silo.

\section{STONE'S WAGON POLE SUPPORT}

This splendid device carries the tongue, neck-yoke and whiffletrees. Gives greater comfort, being free from the horses' necks. These supports have sufficient length of steel to make them flexible and easy on tongue and hounds. This spring relieves the horse of entire weight. Does not affect running of wagon. It prevents sore necks. Keeps tongue off the ground, easily applied. Price $\$ 2.50$ 


\section{THE IMPROVED THREE-ROW CORN MARKER}

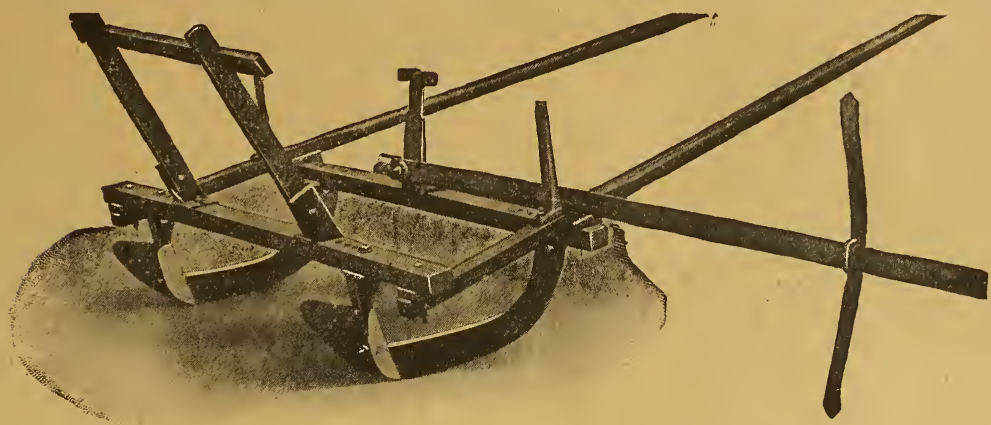

This out shows our Steel Wing Marker. The runners are long, which enables it to make true and evea mark. It is adjustable to mark any width row and any depth desired.

Two-Row Marker for one horse, \$9.r0. Three-Row Marker for two horses, \$10.00.

\section{Bemis Transplanter}

Sets all kinds of plants like cabbage, tobacco, etc. The sucoess of piant setting is assured by its use. The most successful planter on the market. Made near by, and all parte supplied on a few hours' notice. Price \$75.00.

\section{FARMERS'} COMBINATION CLAMP
AND DRILL.

$\$ 3.00$ with Diamond Point Drills. $\$ 3.50$ with Syracuse Twist Drills.

The lowest priced first class article of its kind on the market. Can be used as a wood clamp, also a benoh vice, or hand drill.

\section{PROUT'S HOEING MACHINE}

\section{The Representative Tool of Level Cultivation}

A perfect substitute for hand hoeing. or flat cultivation, as desired:

Now made with handles adjustable for tall or short operator and with improved standard as shown.

It cuts over all the ground, and tears out every weed by the roots, leaving the fields clean in the fall.

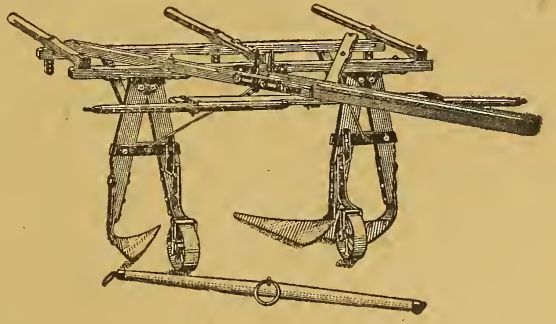

It is worth its cost for ridding a farm of weeds.

It will not injure the corn roots, while it leaves the land level.

It is unequaled by any other tool in the cultivation of corn, potatoes, tobacco and all kinds of root crops. Not a new and untried machine, but thousands already in use, giving unequaled satisfaction. It materially lessens the cost of hand labor, while it increases the crops. You cannot afford to be without one. Ask for further particulars. Price $\$ 25.00$. 


\section{THE OSBORNE WINDROW HAY LOADER}

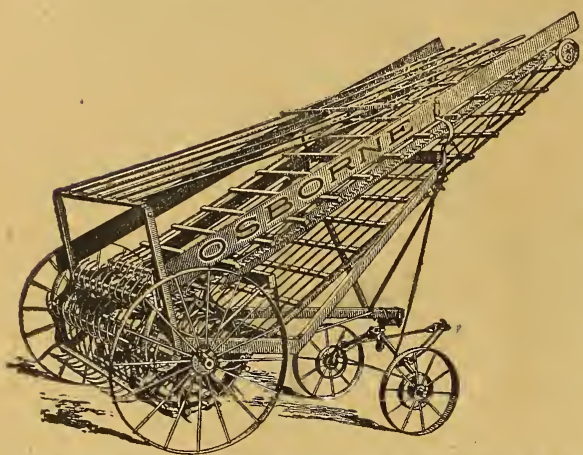

The Osborne is a remarkably simple loader -in fact, it would be difficult to imagine a more simple loader. The entire mechanism of this loader consists of a gathering drum, which picks up the hay, and and elevator carrier, the elevator carrier is operated by the gathering drum.

The gathering drum is fastened to the main axle and is driven by both wheels. As a result of this construction, the gathering drum is raised and lowered with the wheels in passing over dead furrows and uneven ground. This insures all the hay being gathered irrespective of the condition of the ground. A wind break is provided, which prevents the hay from being blown from the carrier; the wind break is very effective and automatically adjusts itself to different conditions of hay. A tightening device allows the tension of the carrier to be properly adjusted. The Osborne loader is equipped with a fore carriage which carries a part of the weight of the loader. This relieves the loader of the twists and strains which would result were no fore carriage used. . It also makes it unnecessary for the loader to be lifted when being connected to the wagon, as the hitch may be moved to any position. It permits the driver to disconnect the loader from the wagon without requiring him to get down off the load. When the load is complete he simply pulls the rope which extends up to the top of the load from the hook on the fore carriage. When disconnected from the wagon the loader is held in an upright position by the fore carriage. Loader can be used with any height of farm wagon without any readjusting or changes.

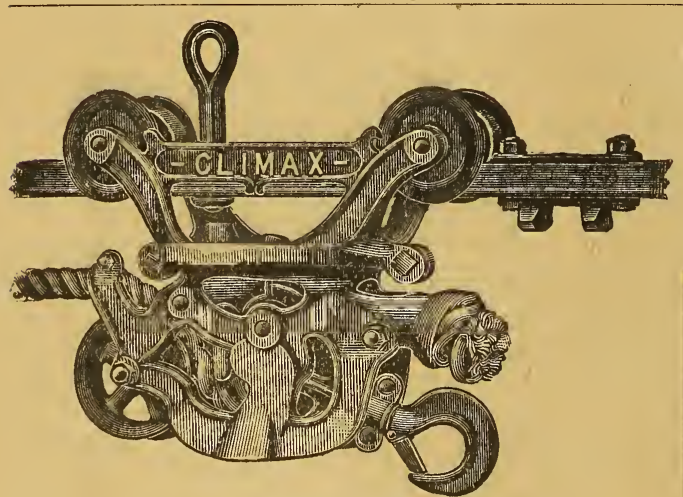

THE NEY

\section{GLIMAX OPEN THROAT GARRIER.}

With this carrier, it is possible to fill the mow oloser to the nomb of the roof than with any other carrier on the market. The throat has an exceptionally large opening, and the simple locking mechanism is so arranged that the lifting head or pulley locks directly on the sides or frame of the carrier, not depending on sepurate dogs or locks to hold the load. It is constructed and operated without the use of springs, and Jegages projections upon lifting pulley in a line with axis of pulley. This permits the pulley to swing very near the track and enables the carrier to work under conditions where any other carrier would necessarily tall.

CARRORUNIDUM SCYTHE STONEN

Do away with the grinding of a scythe altoxether. Th $\leftrightarrow$ y produce a clean. sharp edge and do it faster and ormier than it could be done on the best grindstone over made.

Carborundum Scythe Stones must not be classed with the ordinary seythe stones that you have been accustomed to. The old style stones are merely sand. stone and are of very little use. They simply RUB the edge into shape-Carborundum CUTS it-cuts it fast and clean and puts an edge on your scythe that will be a revelation to you. Price, BOc.

\section{REVERSIBLE HAY CARRIERS. For either Steel or Wood Track.}

Light and Durable, Runs either way on the track without changing. Price, \$4.50.

Ney Hay Car, steel or wood track $\$ 500$ Climax Car, open throat . . . 500 Double Harpoon Forks : . . . 150 Double Harpoon Alfalfa Fork . . 600

Steol Track per foot . . . . . 13 Pulieys in Wood and I con, each, 35 to 60 Hanger Hooks, doz. . . . . . 100

Brackets, doz. . . . . . . . 75

Floor Hooks, each . . . . . . 15

Tedder Teeth, each . . . . . . 40

Horse Rake Teeth : . : . . . 35

Rope, best Manilla, at lowest prices.

All Steol Hay Tedder . . . . 4500 Osborne Rake. 2500 to 3000 New Yorker Horse Rake . 2200 to 2400 We carry Haying Tools of ail kinds. Also Teeth for all Rakes and Tedders.

\section{CARBORUNDUM GRINDSTONES}

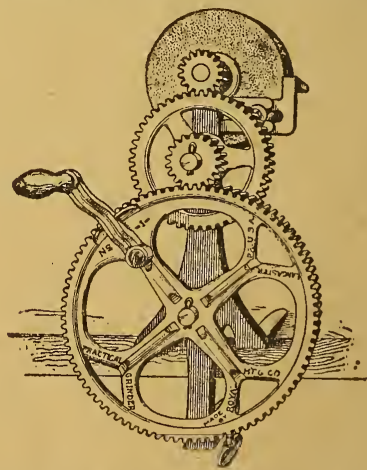

This na taken the place of all Grind ing Stones where quick results are desired. Prices based upon size. $\$ 2.00$ and up 


\section{FLEXIBLE FRAME LAND ROLLER}

Runs smoothly with light draft and turns square corners.

Rolls out dead furrows easily and effectively.

Follows uneven surfaces and rolls the hollows as well as the high places.

Rolls all the ground-no strips left between sections.

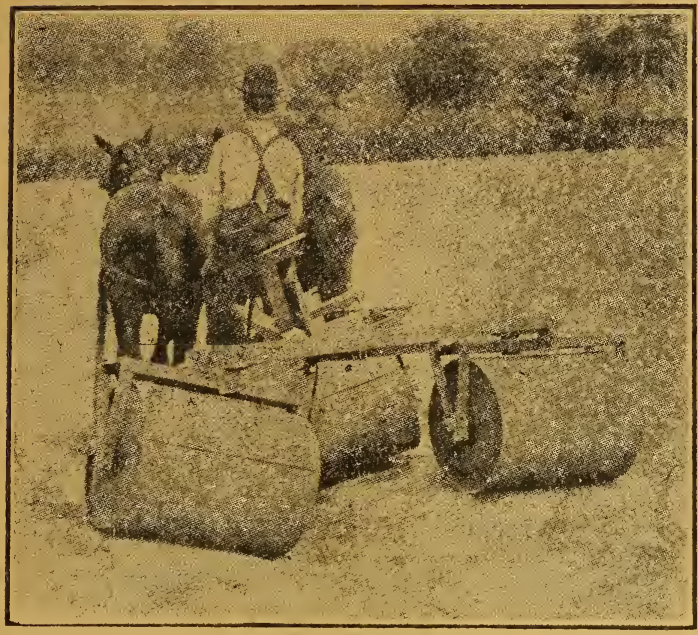

Rolling a Dead Furrow.
In this hillside field, sloping in two directions, a dead furrow was plowed to afford drainage.

This, after several years, has been widened and deepened to a shallow channel. No plan of rolling such a field with an ordinary rigid roller would give sat. isfactory results without much extra work. Notice how the Flexible Roller goes down the field adapting itself to the uneven surface and rolling every inch of ground. 3 section, $9 \mathrm{ft}$. steel frame, steel face, $\$ 45.00$.

Former Congressman Hon. John R. Clancy of this city, who owns a large farm near Skaneateles, N. Y., is using one of these splendid rollers.

\section{INTERNATIONAL GAS ENGINES \\ TO OPERATE ON GAS, GASOLINE, NAPHTHA OR ALCOHOL} AIR COOLED 1-HORSE POWER, WATER COOLED 2, 3, 4 AND 6-HORSE POWER

These engines are the same as the stationary type, but are mounted on substantial wood skids. This is a very desirable feature for farm work, as they can be moved from one job to another. We are offering our stock of these splendid new International Gas Engines at cost to close out our stock. This will make a splendid opportunity for those in need of it. We have in stock two, three, four and six horsepower agines. Put in an early order before these are sold out.

\section{EMERSON BRANTINGHAM LINE Mowers-Hay Loaders-Side Delivery Rakes-Manure Spreaders, Etc.}

These celebrated and reliable Implements are known from the Atlantic to the Pacilc, for their reliability and up-to-date features. Ask for booklet and special prices. A large stock is carried at our warehouse at 538 and 540 Canal Street.

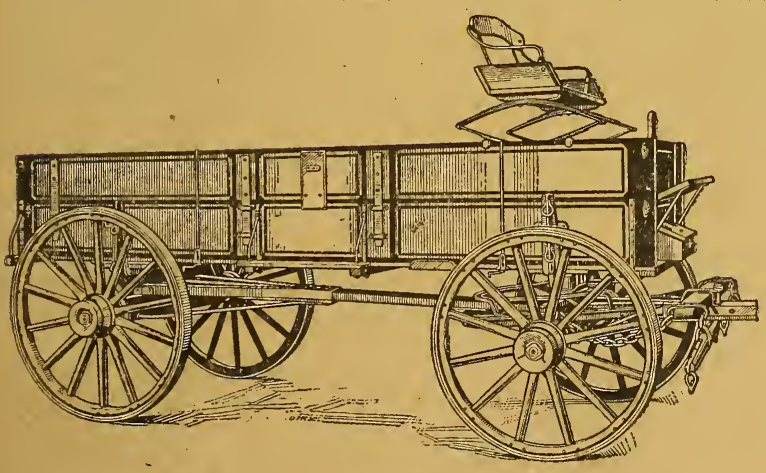

\section{Steel King} and Bettendorf Wagons When you want longer or shorter stakes on a Steel King Wagon, all you have to do is to remove a bolt, adjust the stake to $8,10,12$, or 14 inches in height, and replace the bolt. Tho stake is then just as solld as Il it were built in place at that height. This is one convenience that every Steel King user enjoys. What do you think of it? The stakes are steel, built in the shape of an "I" beam, for whick there's a reason; we'll tell you when you come in. 


\section{LOW 20TH CENTURY MANURE SPREADER}

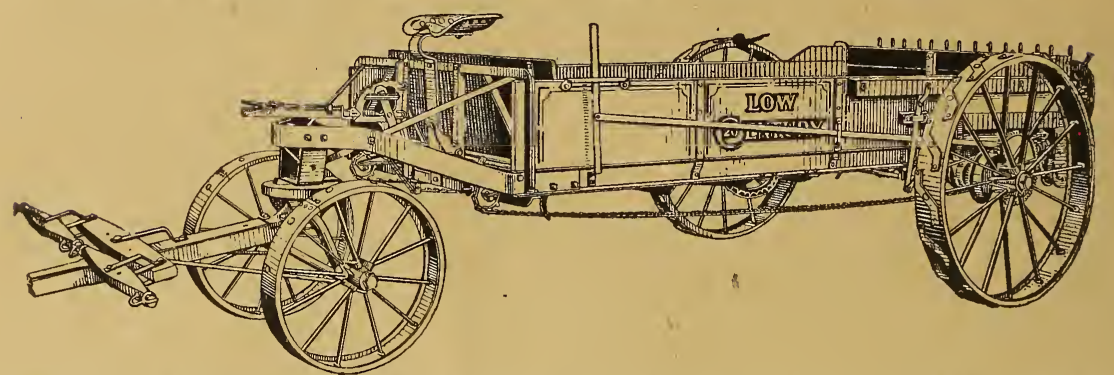

The Low 20th Century is a low down Spreader and has all the advantages that go with a spreader of low-down construction. However, the Low 20th Century has: overcome the one great objection in low-down spreaders in that it has sufficient clear. ance space under the machine to allow it to be used advantageously any place from which and in which a load can be drawn. The driver absolutely gives no attention to. the clearance feature. The Low 20th Century is high enough to pass over any obstruc. thon that one would attempt to drive over under ordinary conditions.

The Low 20th Century is manufactured in four sizes. There is a size adapted to the small truck farm, as well as one for our largest farms.

The Low 20th Century Spreader is strong because it is built of steel; the controlling levers, and even the seat, are steel.

The only wood entering into the construction of the Low 20th Century is in the sides of the box, the apron slats, the tongue and beater rails. The Low 20th Century Is built for service and durability; this is the reason for so much steel being put into It.

The Low 20th Century spreads evenly on the turns; it has a differential similar to that found in the hub of the Osborne Mower wheel, which allows one wheel to hold the pivot while making short turns without affecting the action of the beaters.

Syracuse, N. Y.

My Dear Mr. Ebeling:-The No. 2 Twentieth Century Low Down Spreader purchased of you is giving the University farm management great satisfaction. It is a positive pleasure to see it work. The draft is easy for such a machine and the distribution even and rapid.

Very respectfully,

JAMES R. DAY,

Dictated.

Chancellor Syracuse University and Agricultural College.

\section{EMPIRE GRAIN DRILLS}

Empire Drills deposit the seed uniformily a nd cover evenly so that the field does not have thick and thin patches to cause unequal growth. This insures uniform results and - larger yield.

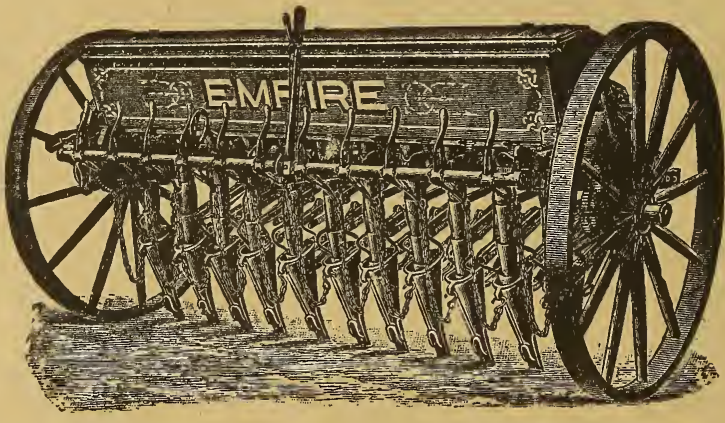

The Empire line is complete a $n d$ comprises grain, fertilizer. and corn drills. When you buy an Empire Drill, you get one that has been bullt especially for your particular locality, a n d therefore is the drill best suited for your work.

Empire Fertilizer $11 \times 7$ Open Delivery Single Disk Drill, equipped with Internal

On the Empire Fertilizer Drill the quantity of fertilizer can be varied from 40 to 1,185 pounds to the acre. You can make this variation in feed without stopping the toam. That is a drill feature worth having, but read on. Instead of depending upon the hopper for support, Empire drill grooves hold up the hopper. The Empire lood yoke is in one piece, therefore it is impossible for the pinions to get out of line. You know what that means.

Empire internal or double run grain feed cups sow all kinds of grain, as well as corn, large peas, Lima beans, red kidney beans, etc.; cup consists of but four parts, held by one bolt, which may be tightened to take up wear.

Price, 9 Tube, $\$ 90.00 ; 11$ Tube, $\$ 100.00$. 


\section{CROWN LIME AND FERTILIZER BROADCASTERS}

CROWN Broadcasters are constructed principally to sow Lime; they also handle perfectly all kinds of fertilizers and other soil beneficiaries. All soil can be made more productive either by the application of some form of Lime to neutralize the free acid therein, or by the application of some other allsaline or in some cases an acid element to complete the neutral condition. Most plants are adapted by long practice to grow in soil that is approximately neutral. CROWN Broadcasters are specially adapted to distribute accurately any element which the soil requires.

CROWN Broadcasters are strong machines. Box rooms ten bushels. Force feed is attached

directly on the main drive axle. No gears to freeze, strip or break. Ratchet wheels. Quantity can be changed instantly by one lever in center of hopper. CROWN Broadcasters are built to last. Price, $\$ 38.00$ to $\$ 45.00$.

\section{FARMER'S}

FAVORITE

\section{COOKERS}

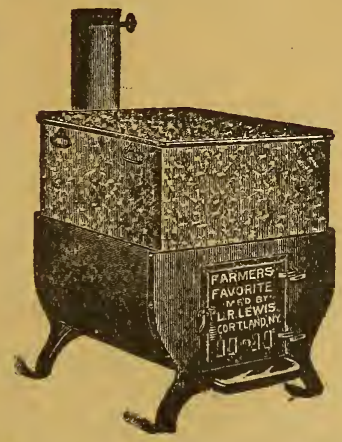

Size boiler. Size Fire Box. Price. No. $230 \mathrm{gal}$...22x24x13 1-2..24 Inches $\$ 1300$ No. 310 " $.22 \times 30 \times 14 \quad .30$ " . 1400 No. 4 50 " $.22 \times 36 \times 15 \quad .36$ " " 1500 No. $575 \quad$ " $22 \times 48 \times 17 \quad \ldots 48 \quad$ “ . 1700

The Farmers' Favorite is used for a great Tiriety of purposes, such as cooking grain and vegetables for stock and poultry. Heating water for scalding hogs and poultry. Boiling spraying mixture. Heating water on wash day. Heating water for washing dairy utenstls. Rendering lard and tallow. Bolling sorghum.

Heating drinking water for stock. Syruping down. Bolling clder. Preserving and evaporating fruit. Sugaring off. Boiling sap. In addition to the above, by using a top plate in place of the boiler it converts the cooker into a flrst-class stove for warming a.milk room, hog house, poultry house, cellar or shop. Can you think of any other farm implement that can be used for so great a variety of purposes? The farm equipment is incomplete without one of these cookers.

Add $\$ 4.00$ for grate, for coal or coke

\section{The Chatham Fanning Mill}

The secret of big crops is planting Pure, Healthy, Fat Seed!

The way to get such seed is to own this magic machine-the Chatham Mill. It's the greatest money-making farm machine on earth.

\section{GRAIN GRADER, CLEANER AND SEPARATOR}

Handles Wheat, Oats, Corn, Flax, Buckwheat. Timothy Seed, Clover Seed-in fact, any grain or grass seed. Cleans, grades and separates all at one operation. Makes you independent-puts an end to planting foul, dirty seeds that grow poor crops and weeds. The "Chatham" handles 60 bushels per HOUR. Runs by hand or gas power.

Over 350,000 "Chathams" are now used on farms-they are recommended by every

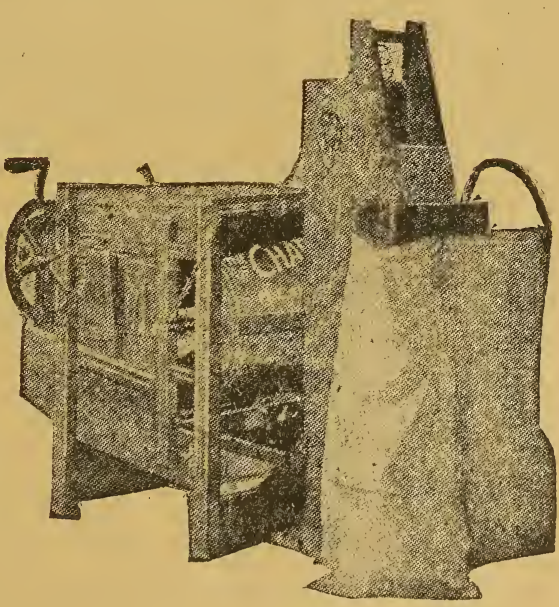
Agricultural Authority in the countrv. They make farming easier and a sreat deal more profitable. Price $\$ 35.00$.

\section{With Bagging Attachment, $\$ 40.00$}

E. B. Ford, Branchport, Yates Co., N. Y., won the first prize on Red and White Wheat at the Syracuse State Fair 1914, and which was graded and recleaned with one of our celebrated Chatham Fanning Mills. "A word to the wise farmer is sufficient." 


\section{DICK'S NEW IMPROVED “BLIZZARD” CUTTER}

\section{With Superior Self-Feed Table. Also with Plain Feed Table}

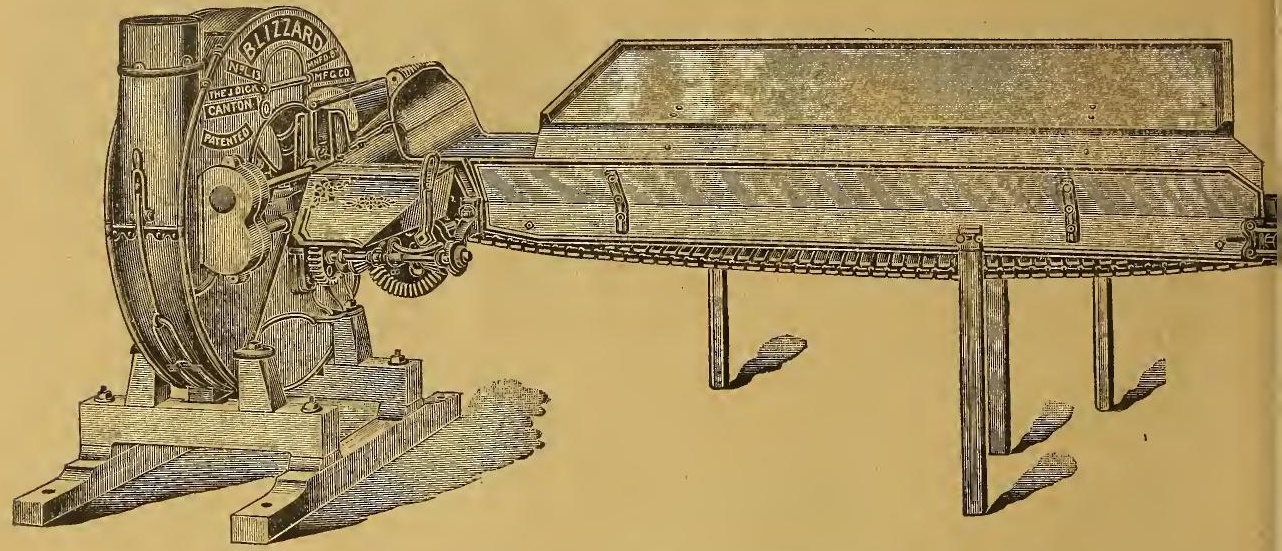

The Blizzard is an entirely new departure in feed and ensilage cutting machinery, and we feel safe in stating that owing to the numerous points of merit in this combined machine for cutting, splitting or shredding feed, and elevating it by means of a pneumatic conveyor and deflector, the Blizzard excels all others of its class.

The gearing on this improved machine is 50 per cent stronger and has much more wearing surface, while the shafts for feed gears are larger in diameter; in fact all the parts throughout are made much heavier and stronger, and can stand more strain and extended service than the former style "Blizzard." These machines are now constructed with a third bearing for main shaft; the important feature of this improvement is that it supports the bearing of belt pulley overcoming the strain of the drive belt, and by this device it cannot spring the main shaft, which remains absolutely in line with the remaining two bearings. The feed table can be detached before removing from the machine, by simply we claim that the "New Improved Blizzard" is ahead of all ensilage and feed cutters on the market today.

\begin{tabular}{|c|c|c|c|c|c|}
\hline & $\begin{array}{l}\text { Length of } \\
\text { Knives }\end{array}$ & $\begin{array}{l}\text { Capacity per Hour } \\
\text { Green Ensilage }\end{array}$ & $\begin{array}{l}\text { Steam Power } \\
\text { Required }\end{array}$ & $\begin{array}{l}\text { Speed } \\
\text { Revolutions }\end{array}$ & $\begin{array}{c}\text { With } \\
\text { Traveling Table } \\
\text { Price }\end{array}$ \\
\hline $\begin{array}{l}11 \\
13 \\
15\end{array}$ & $\begin{array}{l}111 / 2 \text { in. } \\
14 \text { in. } \\
16 \text { in. } \\
181 / 2 \text { in. }\end{array}$ & $\begin{array}{l}4 \text { to } 6 \text { tons } \\
5 \text { to } 8 \text { tons } \\
7 \text { to } 12 \text { tons } \\
9 \text { to } 14 \text { tons }\end{array}$ & $\begin{array}{ll}31 / 2 \text { to } 5 \text { H.P. } \\
4 \text { to } 7 \text { H.P. } \\
7 \text { to } 10 \text { H.P. } \\
8 \text { to } 12 \text { H.P. }\end{array}$ & $\begin{array}{l}900 \text { to } 1100 \\
800 \text { to } 1050 \\
650 \text { to } 1000 \\
600 \text { to } 950\end{array}$ & $\begin{array}{l}\$ 110.00 \\
135.00 \\
170.00 \\
215.00\end{array}$ \\
\hline
\end{tabular}

Wagon trucks complete for mounting and transporting above cutters, for Nos. 9 and $11, \$ 35.00$; for No. $13, \$ 35.00$.

Price of cutter does not include pipe, angle clamp joints or deflectors.

$$
\text { For No. M } 9
$$

6 -inch Galvanized Pipe, per foot..........\$.50 6 -inch Deflector for end of pipe.............. 8.50 For No. M 11

7 -inch Galvanized Pipe, per foot........... .55 7 -inch Deflector for end of pipe.............. 8.50 For No. M 13

$71 / 2$-inch Galvanized Pipe, per foot........\$.60 $71 / 2$-inch Deflector for end of pipe............ 8.50 For No: M 15

8 -inch Galvanized Pipe, per foot...........\$.60 8 -inch Deflector for end of pipe........... 8.50

\section{With Flexible Distributing Pipe}

\section{for Inside Silo}

A now sectional distributing pipe used in connection with regular improved Silage Distributer. At end of the Distributer on two adjustable iron rods is attached a Hopper which in turn supports the section al pipe. The device used for locking the pipe sections together is strong, durable, simple in construction, and what is of equal importance, makes the pipe very flexible. Price $\$ 2.00$.

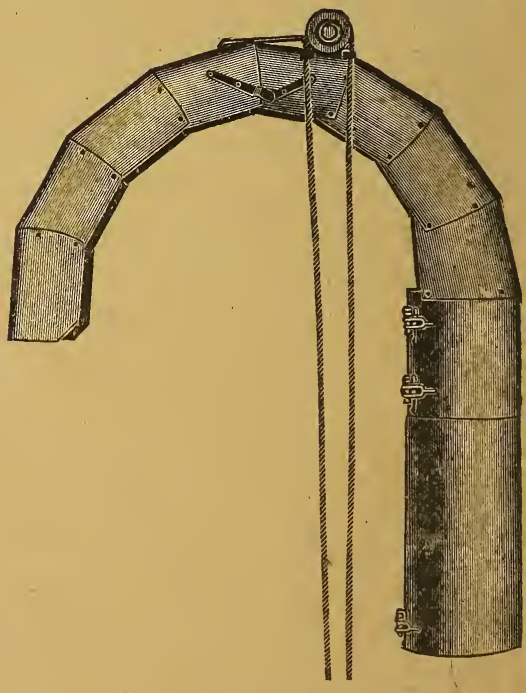

Patent Deflector 
F. H. EBELING, SEEDS AND FARM SUPPLIES, SYRACUSE, N. Y.

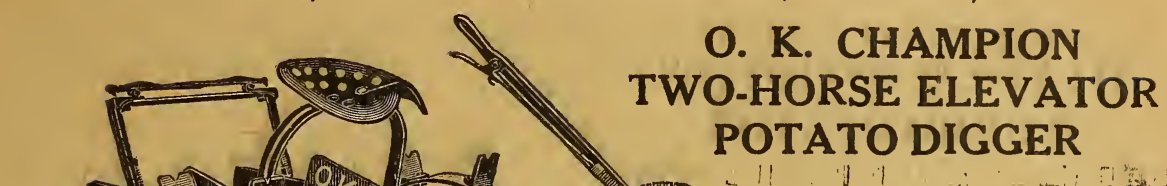

The No. 1 Digger has a front throat which is a new departure in digger construction and exchusively used on our machine. It consists of patented, specially constructed side plates which connect with beams that taper downward toward

conect whe makes the threat opening wider than the body of the machine, allowing the dirt to spread and lose itself more freely when first entering. It also forces the vines and weeds to slide up more essily and overcome the serious trouble of clogging. The inward extending base to which the shovel is bolted makes the opening absolutely rigid and strong.

This Digger is designed and built to embody every important point of construction which insures freedom from breakdowns, costly waits and expensive repair bills. It is adapted to the various duties which may be imposed upon it and will meet successfully the broad variance of conditions under which it may be worked. Its strength, simplicity durability, capacity and economy are the vital factors which should receive consideration. It is strictly a Two-horse Elevator Digger; two ordinary horses will do the work with ease.

\section{O. K. CHAMPION POTATO DIGGER NO. 2}

The No. 2 Machine is in design exactly as the regular No. 1 Digger, $\cdot$ varying only in size and dimensions, the elevator being two inches wider and ten inches longer, all other parts being built proportionately larger. This Digger has a very large capacity, the separating space being approximately fourteen square feet, which fact makes it especially adapted for hea.vy soil.

Dimensions:-22 inches between sides; equipped with patented front throat which allows the dirt to spread twenty-six inches; main wheels 35 inches high, fitted with removable lugs. The front truck is of the swivel type and makes turning to any angle or distance very easy.

\section{O. K. CHAMPION POTATO DIGGER NO. 3 WITH EXTENSION ELEVATOR} A HIGH-CLASS, DURABLE AND EFFICIENT MACHINE

This Digger is constructed with the view of producing the best results with the loast mechanism so as to avoid complication and cause as little friction as possible. It is amply strong for any soil or condition of field; its capacity sufficient, having over fifteen square feet of separating space. Its simplicity is one of the main features because it lessens the possibility of wear and breakage.

The Elevator is an endless link chain, constructed of $3 / 8-i n c h$ round, high carbon, crucible analysis spring steel. This is the best material that can be obtained for this purpose. The links of this chain are'alternately rassed ard lowered, a feature original with O. K. Champion Diggers, which materially adds to the separating capacity without increasing the resistance and thereby greatly reducing the power requirements. Two sets of oblong sprocket agitators are provided which supply the chain with a continuous agitation while in motion.

The Main Wheels are 35 inches high, made of steel, with reinforeed cast hubs and are nited with rovovable lugs.

Dimensions:-32 inches wide between sides; equipped with patented front throat; main wheels 35 inches high, ntted with removable lugs. The front truek is of the swivel type and makes twraing very essy. PRICES-No. 1, $\$ 70.00 ;$ No. $2, \$ 85.00 ;$ No. $3, \$ 100.00$.

Sept. 15, 1914

F. H. EBELING:-

Clay, N. Y., R. F. D. 2.

Dear Sir-The No. 1 Champion Potato Digger that I bought of you is doing such good work that I could not get along without it. It works perfectly and I would not he without it
for $\$ 100$.

Prices subject to change without notice. GUSTAVE SCHULKE. 


\section{Replace Your Old Gates With The Low Priced CanitSas}

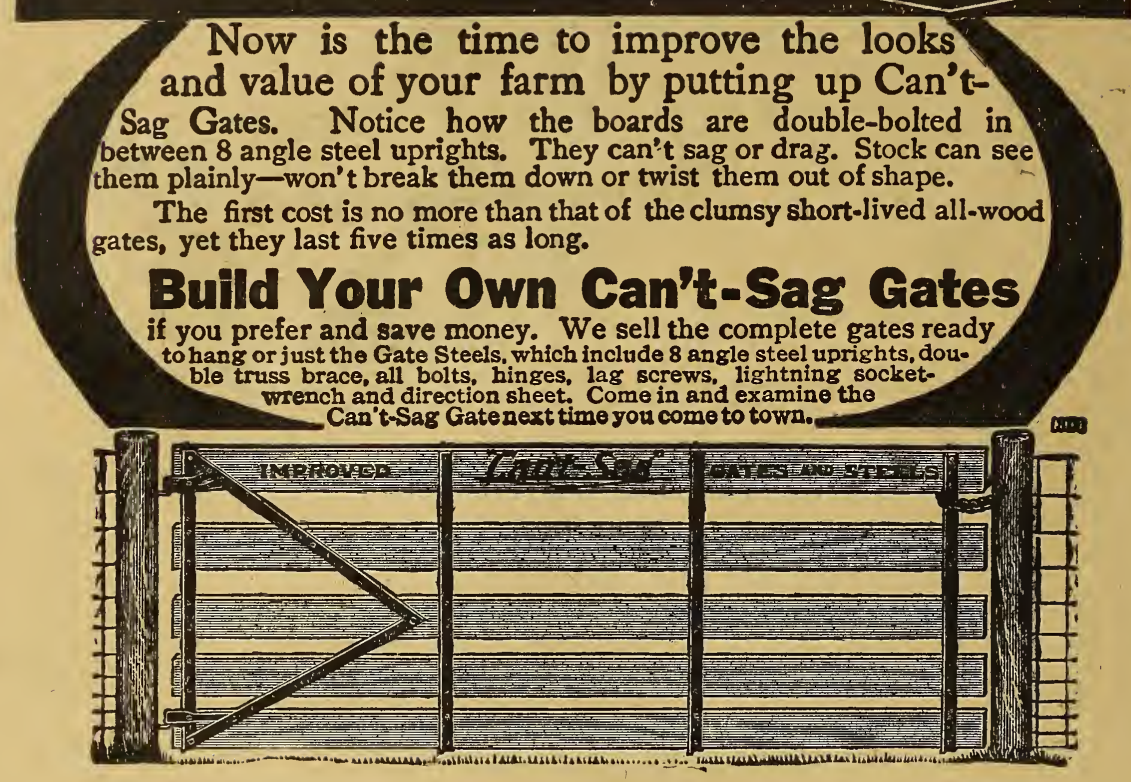

\section{CAN'T-SAG FARM GATE}

This splendid farm gate does away with all the old gate troubles that have harassed farmers for many years. They will stay just as they are put up. Will not sag, always ready for business, made of best material, and is the only real dependable wood gate on the market. A trial of this gate will introduce a lot more of them in your neighborhood.

14 -foot Gate, \$5.00. Steel metal parts for “Can't-Sag Gate," $\$ 2.75$.

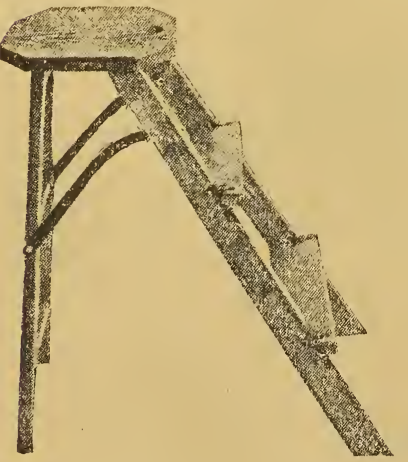

\section{INVINCIBLE STEP STOOL}

Safe-Handy-Convenient IN THE HOME

IT takes the place of a ladder in cleaning house.

IT saves your strength by using as a Stool when preparing vegetables, ironing, \&c.

IT slides under the Kitchen Table or hangs on the wall, when not in use.

\section{AT THE STORE}

IT is ready every time that you need to step up or sit down.

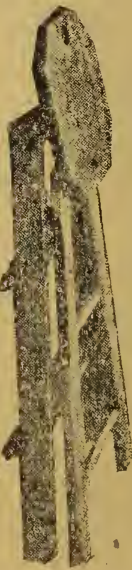




\section{DANA'S STOCK LABELS}

Stamped to order with letters and serial numbers.

For Cattle, Sheep, Hogss, Stc. Cattle Labels, . . 75c dozen, $\$ 3.50$ per 100 Sheep and Hog Labels, 50o doz., $\$ 2.75$ per 100 Punches for Cattle, . . . . . $\$ 1.50$ each “ " Sheep and Hogs, . 1.25 each

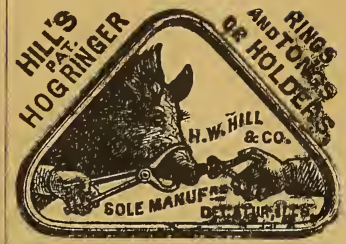
Bull Nose Punch, . . . . . . 1.50 eroh The above malled you upon receipt of price named.

\section{HAND AND POWER

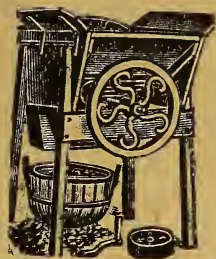

Banner Root Cutter

Has a capacity of 30 to 100 bushels per hour. One bushel per minute has been cut as a a test, many times.

It saves the price of a cow, as they cannot chnke when fed on roots cut by this machine. No. $20 \$ 9.00 ;$ No. $30 \$ 16.00$

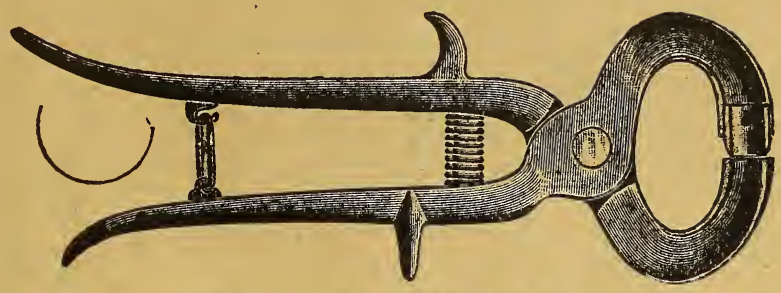

Dana's Bull Nose Punch.

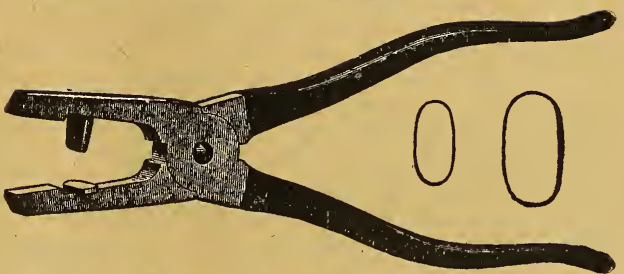

Dana's Catle and Sheep Punch.

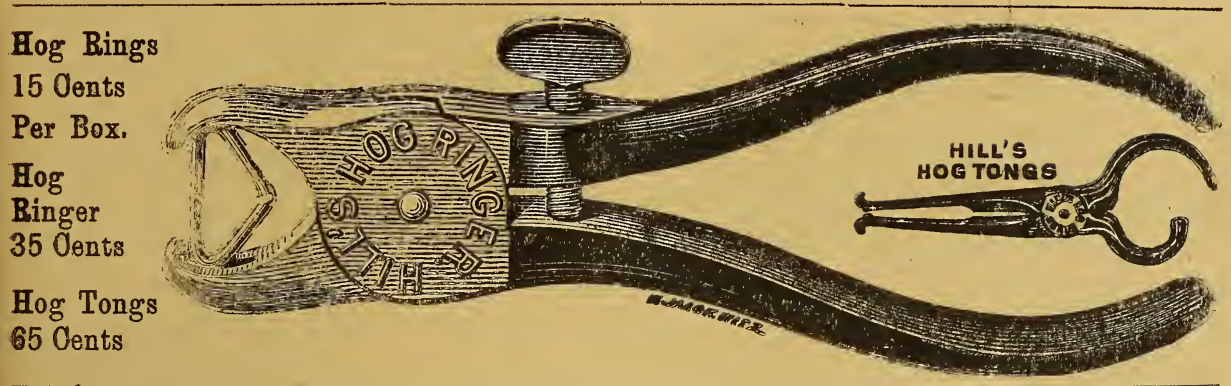

\section{CASTINGS REPAIRED}

Cast Iron, Steel and other Metals repaired and mended on short notice by the new welding process. Bring in your parts for repairing. This work can be done on short notice and old or obsolete machinery put into commission through this welding process, enabling farmers to make use of machinery that otherwise would have to be thrown on the scrap heap.

\section{ERRORS}

We sometimes make them, so does everyone! We will CHEERFULLY correct ours if you will write us. How can we correct them if you DON'T? Try to write to us good naturedly, bit if you can't, write to us anyway. Don't kick to anyone else, or nurse a grievance. If we have ever made an error or offended you, it's only simple justice to us to let us know. We correct our mistakes gladly. If our methods don't appeal to you, help us with criticisms from your point of view. It is inevitable that in business letters hastily written should sometimes rub the wrong way. We may be awkward in expressing ourselves, but our goods are honestly sold and we aim to give everyone a square deal. 


\section{WAUKEGAN-CYCLONE SANITARY FENCING}

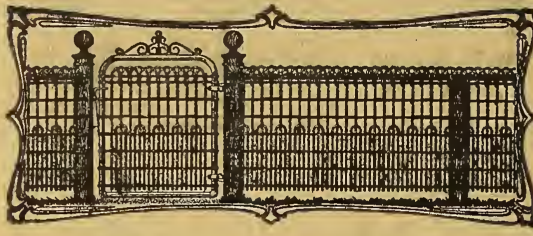
Style "F" is our most popular sanitary air and sunlight. Made of heavily galvanised wire. Pickets spaced 13/8" apart at bottom, $\mathbf{2} \%^{\prime \prime}$ at top. Best heights are $36^{\prime \prime}, 42^{\prime \prime}$ and $48^{\prime \prime}$. Otier heights up to $84^{\prime \prime}$ furnished.

Price per lineal foot, Style "F"- 36 ", 10; $42^{\prime \prime}, 13 \mathrm{c} ; 48^{\prime \prime}, 14 \mathrm{c}$. 3-ft. Gate to match, $\$ 3.00$.

Style "L-Extra" is exactly like Style "F" used. Pickets spaced $27 \%$ " apart, making fence slightly cheaper. Other heights up to 84 " furaished.

Priee per lineal foot, Style "L-Extra"-36", 10e; 49", 11e; 48", 12c.

3-ft. Gate to match, $\$ 3.00$.
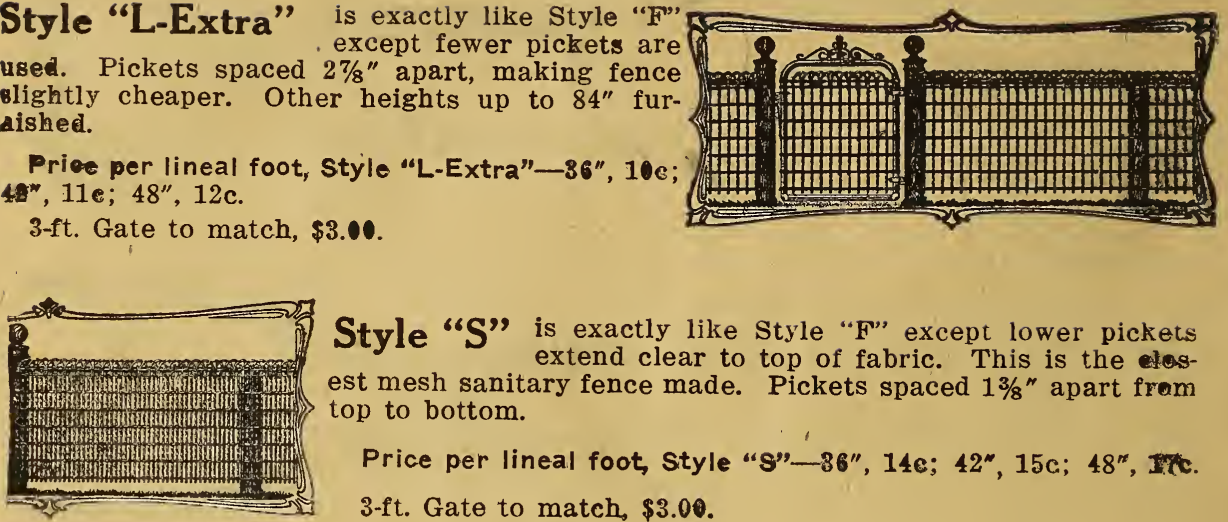

Style "S" is exactly like Style "F" except lower pickets extend clear to top of fabric. This is the elosest mesh sanitary fence made. Pickets spaced $138^{\prime \prime}$ apart from top to bottom.

Price per lineal foot, Style "S"-86", 14ع; $42^{\prime \prime}, 15 \mathrm{c} ; 48^{\prime \prime}$, Itc. 3-ft. Gate to match, $\$ 3.00$.

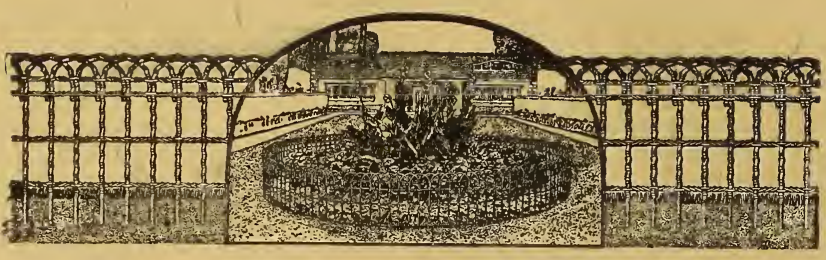

Flower Guard

Keeps out dogs and chickens, protects the flowers, fits any shape or size of bed. Bottom of pickets left straight.

Price per lineal foot$8 \mathrm{c}$.

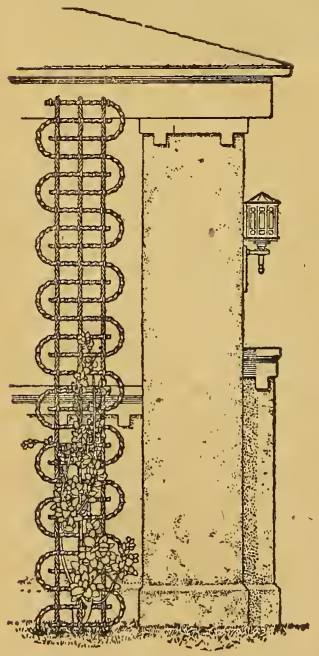

Vine Trellis

Easily placed in position, cut to any length, fits any porch, used from year to year. Made in two widths.

Price per lineal foot-18", 6c; 24", 7e.

\section{Universal Walk Gate}

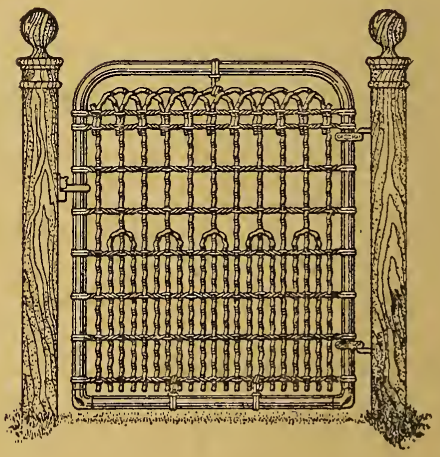

Heavy, high-carbon, steel tubing frame, $11 / 8$ " in diameter. Won't bend nor break. Close mesh fabric; fittings for wood posts. Regular width, 36", 42" and 48".

Price for 3-ft. opening, $\$ 2.50$. 

"AMERICAN" SHEEP, HOG AND GATTLE FENGING

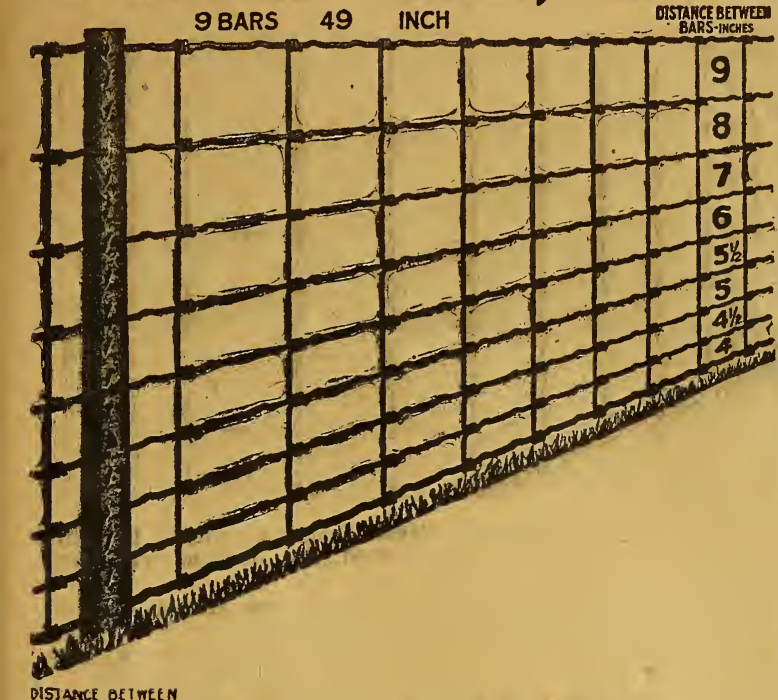

DISTARCE OET TEEE

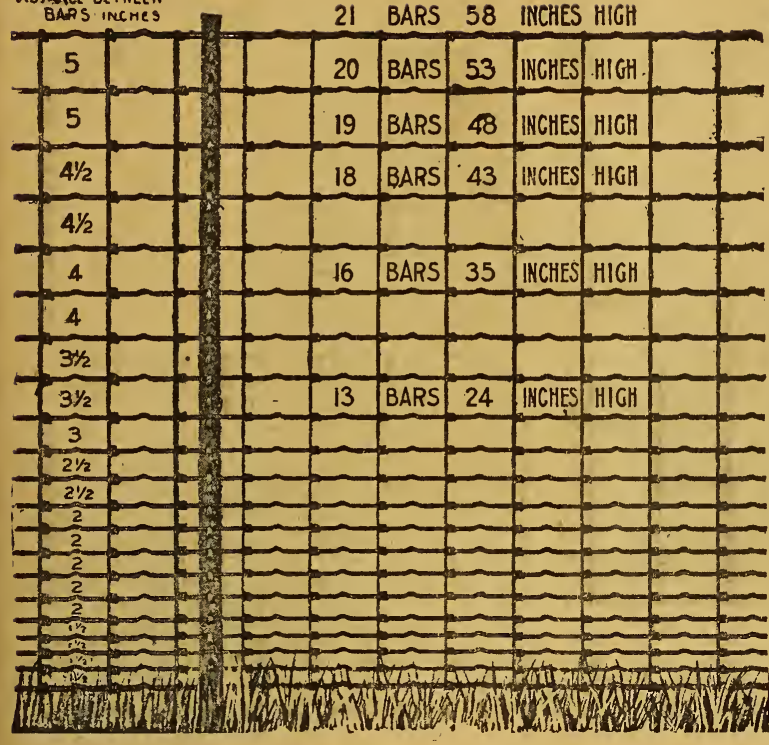

This is a fonoe that fonces and stays lencod. It stands for freedom from worry. With this fence you ean rest easy and neod fear no danger of your stock breaking out.

In this fencing we have every form of fences for sheep, hozs and cattle. It's made in two weights, medium and hoavy.

Here's an especially interesting $f a a-$ ture about this fenolng-it's not only on $\theta$ of the best made but the cost is very small. The price was never so low as now. We have three cars in stock of the leading sizes. Ask or wite for booklet.

The Lost Fonce stretcher is the only tool noesssary for putting up tho American Fiold and Hog Fonoing. Every farmor should own this strotob. or. It costs only $\$ 5$.

\section{A Wonderful Fence}

There's no better renoing made for hoge, cattle, poultry or rabbits. It makes an ideal garden fonoing. It's sirong, thoroughly praotical and more durable than netting. The light spec:Iflcations are strong encugh to turn stock.

This fencing comes in 13 to 21 bars. in 6 inch stays, 24 to 58 inches high, 43c to $71 \mathrm{c}$ per rod.

FENCING, POSTS and GATES

RETAIL PRICE LIST FENCING PR Rod 635 Style $A-12$-inch......... 35 726 Style $A-6$-inch.......... 35 832 Style $A-6$-inch........... .53 845 Style $A-6$-inch........ .57 845 Style A-12-inch......... .45 949 Style A- 6 -inch......... .63 949 Style A-12-inch........... .49 845 Style D-12-inch.......... 64 949 Style D-6-inch........ 1.00 949 Style D-12-inch......... .73 1558 Style $\mathrm{E}-6$-inch............ 1948 Style F- 6-inch........ .64 STEEL FENCE PÖSTS RETAIL PRICE LIST LINE POSTS, $61 / 2$ feet....... .43 LINE POSTS, 7 feet.......... 48 LINE POSTS. 8 feet.......... .55 LINE POSTS, 9 feet ......... 4.65 END POSTS, 8 feet......... 3.08 $14-\mathrm{ft}$. Gate, Yankee, 50 -in....99.00 3 -ft. Single Walk Gate, plain.. 2.75 4-ft. Single Walk Gate, plain.. 3.00

\section{A COTMBINATION TOOL}

Here's the handiest tool a farmer ever can own. Stop and think. It drives, pulls, makes and caves staples. It's wrench aed plncer, nall puller and hammer. It outs, splioes, traightens and Hightens wire. It re. moves trellises.

Saves time and wages; saves cutting hand; saves 70 ur temper, and it saves chasing cattle. You need one. Write now. It's only $\mathbf{\$ 1 . 2 5}$

\section{7--SEVEN TOOLS IN ONE--7 Price \$1.25}

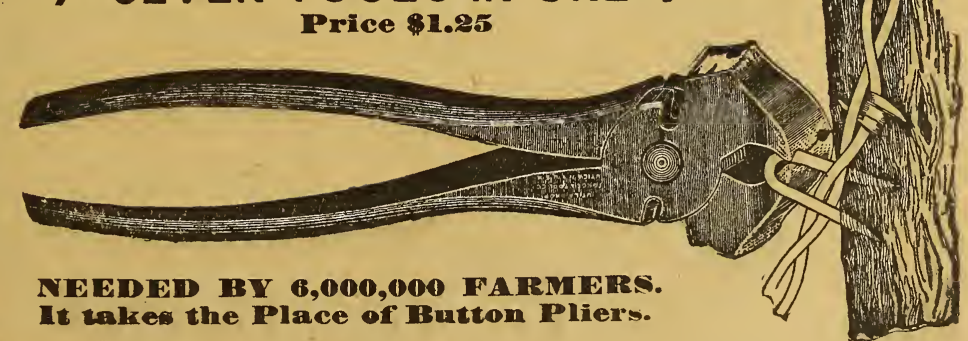




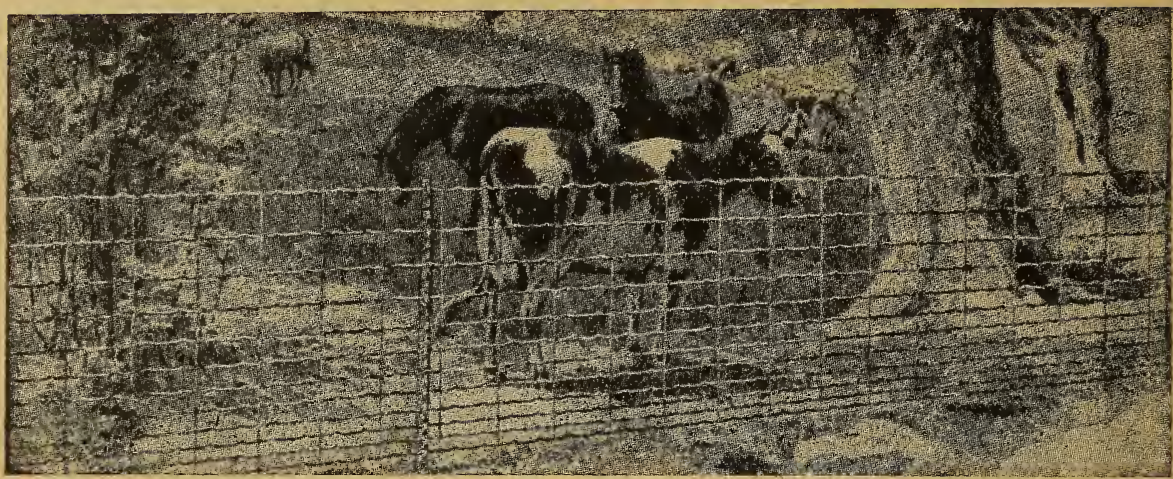

The above illustration indicates design 1258 of American Steel Fencing, which is eminently satisfactory for general farm purposes. The close spacing at the bottom will turo Fogs, also hold Sheep, Cattle and Horses.

We carry a full line of everything in the way of STEEL FENCING for Horses, Steck, Sheep, Hogs and Poultry. Price very reasonable.

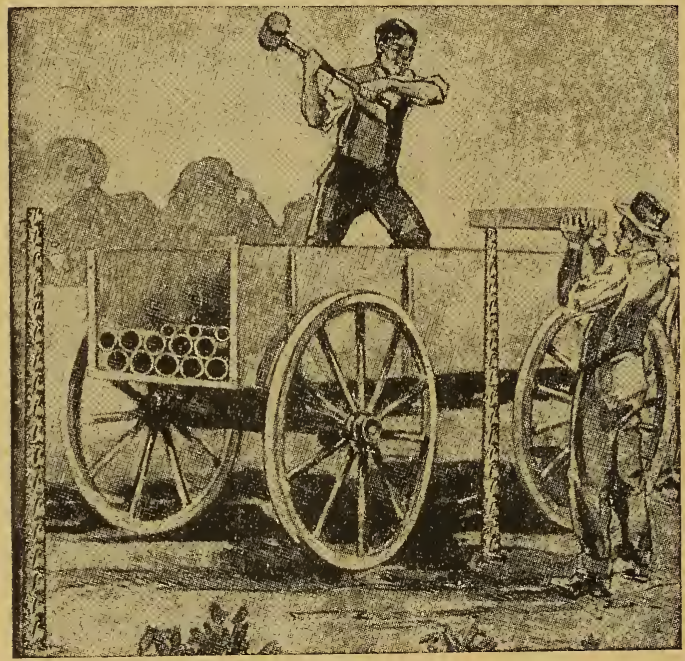

\section{FENCING, POSTS AND GATES PRICE LIST}

FENCING

635. Style A-12-inch............. Per

726 Style $A-6$-inch...............

832 Style $A-6$-inch..................

845 Style A-6-inch........... .57

845 Style A-12-inch ............. 45

949 Style A-6-inch...............63

949 Style A-12-inch............

845 Style D-12-inch..............64

949 Style D- 6-inch............ 1.00

949 Style D-12-inch............... 73

1558 Style E- 6 -inch........... 72

1948 Style $\mathrm{F}-6$-inch............

2158 Style F-6-inch ............ 71

STEEL FENCE POSTS. RETAIL PRICE LIST

IINE POSTS, $61 / 2$ feet..........\$ .48

LINE POSTS, 7 feet............

LINE POSTS, 8 feet............. .55

TINE POSTS, 9 feet........... . .65

CORNER POSTS, 8 feet........ 4.75

END POSTS. 8 feet........... 3.00

14 -ft. Gate, Yankee, 50 -in......... 9.00

3-ft. Single Walk Gate, plain...... 2.75

4 -ft. Single Walk Gate, plain..... 3.00

There's no better fencing made for hogs, cattle, poultry or rabblts. It makes ars tdeal garden fencing. It's strong, thoroughly practical and more durable than netting. The light specifications are strong enough to turn stock.

This fencing comes in 8 to 15 bars, either in 6 or 12 inch stays, 20 to 50 inches high, $25 \mathrm{c}$. to $45 \mathrm{c}$. per rod.

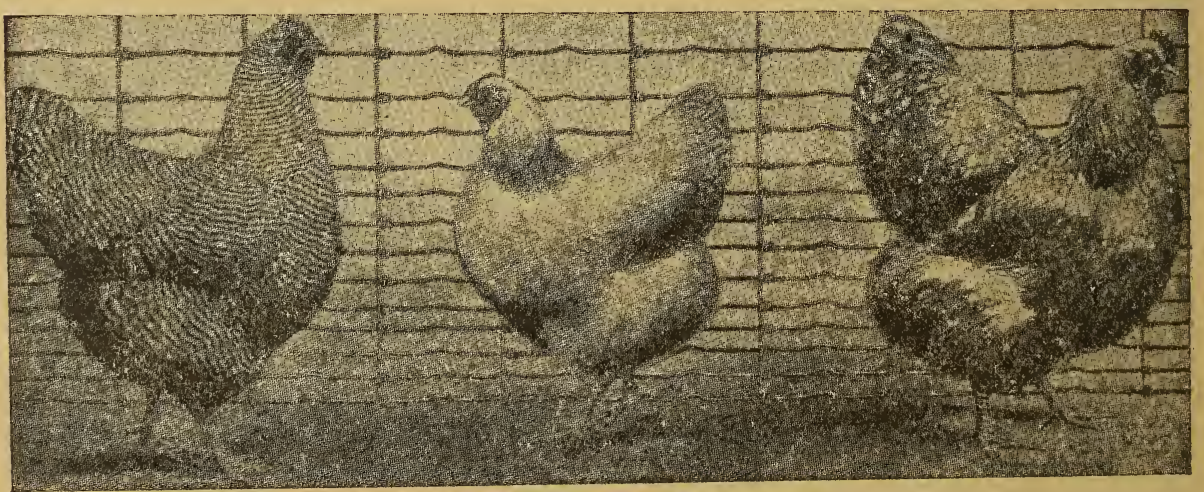


F. H. EBELING, SEEDS AND FARM SUPPLIES, SYRACUSE, $N$. $Y$.

\section{MERIDIAN HAY RACK.}

Manufactured of selected lumber and well bolted. Price, 16-foot, $\$ 14.00$ 14 foot. \$13.c0.

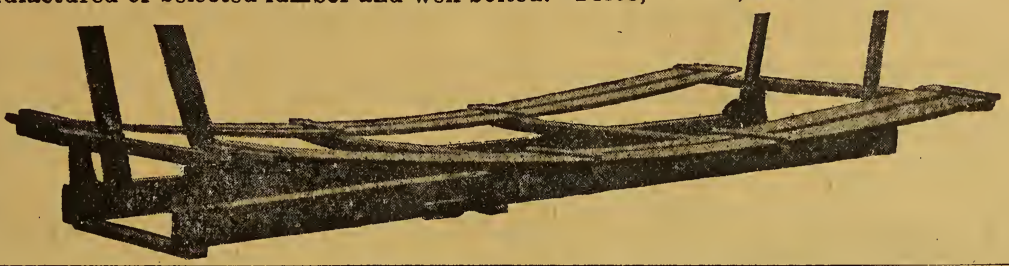

\section{OUR IMPROVED SLIP,}

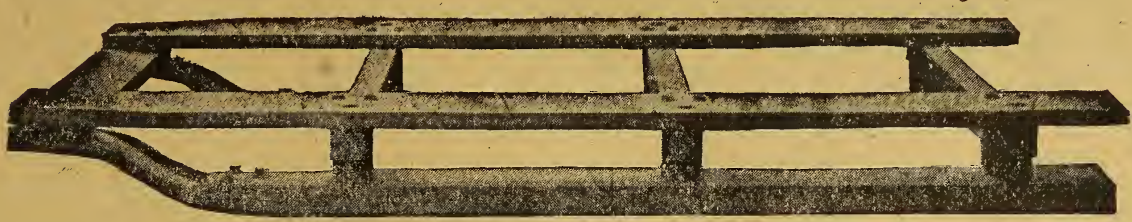

The above cut represents our Improved Slip, which any farmer can make by using our asstisge, which are shown in the front part of the eut. These castings are all finished and ready for the $\mathbf{8 \times 6}$ inch maple runners. Since it is impossible to get Slip Runners sawed with the right swe $\theta$, wny tarmer will appreciate the beneflt of our castings at a glance.

All complete like above cut, $\$ 10.00$.

Set of Shoes for above, $\$ 3.25$

\section{IROIN IIOG TROUGEIS.}

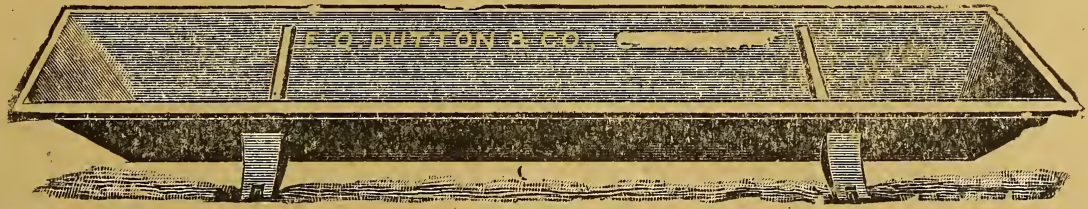

Made in fonr sizes 3. 4, 5. and 6 feet, 8 inches deep, 12 inches wide. Price 50 cents per foot.

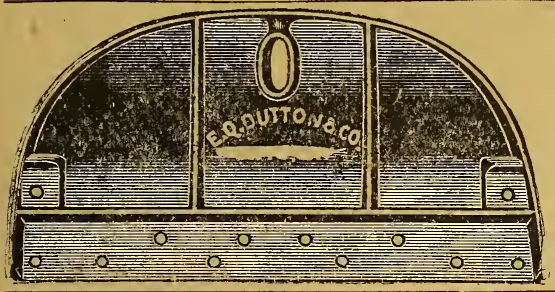

\section{IRON STONE BOAT HEAD.}

A Simple, Complete and Inexpensive derice whereby a Stone Boat can be made in a few minutes by using straight plank. One head will last for years.

\section{Price \$3.25 Each}

GATIDEN

IAARROWS,

4.50
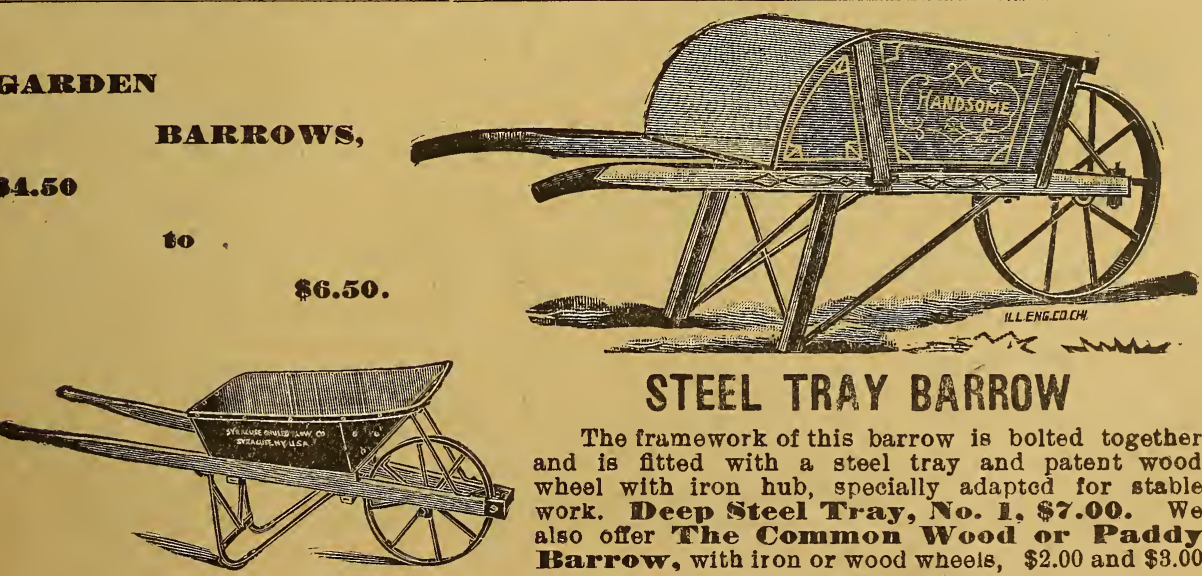

STEEL TRAY BARROW

The framework of this barrow is bolted together and is fitted with a steel tray and patent wood wheel with iron hub, specially adapted for stable work. Deep Steel Tray, No. I. \$7.00. We also offer The Common Wood Dr Paddy Harrow, with ir on or wood wheels, $\$ 2.00$ and $\$ 3.00$

All Prices llable to change without notice. 


\section{GENUINE CYPHERS GOMPANY INCUBATORS PATENTED}

\section{Made in Three Styles-Eight Different Sizes}

Fer the season of 1917 wo offer our customers the Cyphers Incubator Company's complete line of Incubators. These three styles of high class, guaranteed hatching machines, running through eight different sizes, represent all that is efficient, conveniont and reliable in incubator ronstruction. In buying a Cyphers Company Incubator you take no chance.

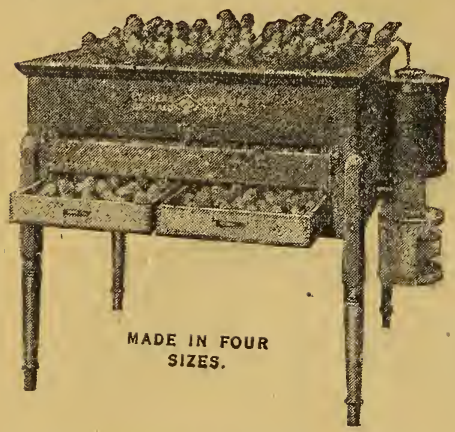

390 Egg Standard Cyphers Incubator. Price Complete, $\$ 44.00$.

\section{Standard Cyphers Incubators}

These are machines that for twenty years have been recognized as the "Standard Hatchers of the World." Tens upon tens of thousands of them have been sold and are in successful use in every civilized country on the globe. They are used by more Government Experiment Stations, on more large, practical poultry plants, on more successful duck and egg farms, and by a larger number of foremost poultry breeders than all other makes combined. They are the last word to date in incubator building, not a penny being spared anywhere in their construction to make sure of their doing satisfactory work in all climes, under widely different conditions, in the hands of all sorts of people. They are built to hatch and to last. With ordinary care they should last an ordinary lifetime. Every Standard Cyphers Incubator is guaranteed by the manufacturers to do first-class work in the hands of every purchaser who will give it a fair trial. Are built in four popular sizes and at prices as follows: 70 eggs, price complete $\$ 16.00 ; 140$ eggs, price complete $\$ 25.00$; 244 eggs, price complete $\$ 37.00 ; 390-400$ eggs, price complete $\$ 44,00$,

\section{Columbia Hot-Air Incubators}

Are built to. meet the wide-spread demand for largecapacity, lamp-heated machines that can be sold at surprisingly low prices and yet be guaranteed to do highclass work. Have wooden cases, attractively finished in dark green, with brass trimmings and double walls. Seamless-bottom lamp bowls, best quality brass burners, zinc and steel Standard Cyphers toggle-joint thermostat and same regulating equipment as used on highest priced machines. Fume-proof, forced draft heater, asbestos covered and metal banded. Automatic in ventilation and embodies diffusive principle. Roomy chick nursery under egg trays. Are made in two sizes: 140 eggs, price complete $\$ 18.00 ; 250$ eggs, price complete $\$ 25.00$. Fully guaranteed.

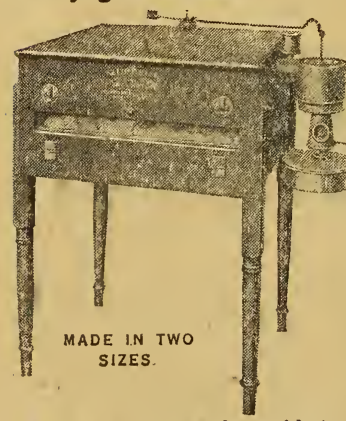

\section{Superior Hot-Water Incubators}

These machines are exactly what the name says. They are heated by hot water, instead of with hot air, and are "superior" in every detail. The water boiler and tank (tubular) are of heavy-weight copper. Lamp has seamless bowl; burner is best on market. Incubator case is of wood, attractively finished in golden brown, with brass trimmings (hinges, buttons, etc.) and has double walls, with air space insulation. Are equipped with Standard Cyphers zinc and steel toggle-joint thermostat and knife-edge regulator. Have forced water circulation and are automatic in ventilation. Roomy chick nurseries. Are built in two sizes: 65 eggs, price $00 \mathrm{~m}$ 130 Egg Superior Hot- plete \$13.00; 130 eggs (see illustration), price complete Complete, $\$ 18.00$.

$\$ 18.00$. Fully guaranteed. 


\section{STANDARD CYPHERS COMBINATION BROODERS AND COLONY ROOSTING COOPS.}

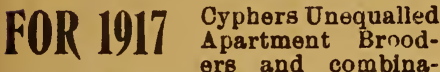
tion roosting coops have the same important advantages over all other makes that are possessed by $\mathrm{Cy}^{-}$ phers Company's 1917 incubators, in that they are fire-proofed and insurable, having the first fire insurance Inspection label over granted on a brooder.

Cyphers 1DIt Brodede, every size and style, \&re self-reguloting. Belf-ventilating and varmint proof. The outdoor styles are useable also as colony coops for the growisg chicks. They are easily and quickly converted into colony roosting ooops by simply taking ont the hover, which is made removable for that purpose.

\section{FIRE-PROOFED, INSURABLE, SELF-REGULATING.}

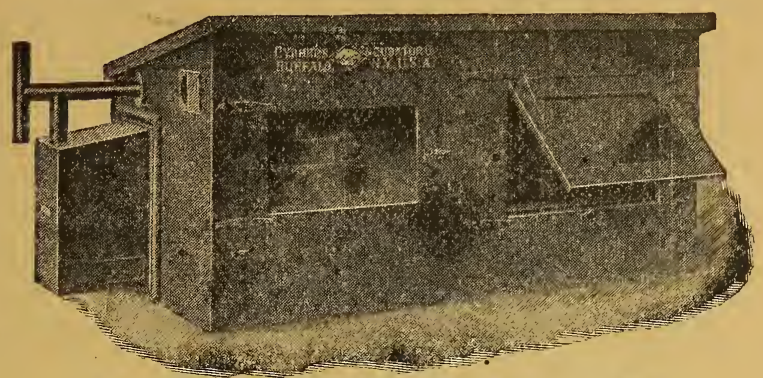

STYYE A OUTDODIR RHOODER.

(Three apartments. Safost and most popular "Foster Mother" ever designed.)

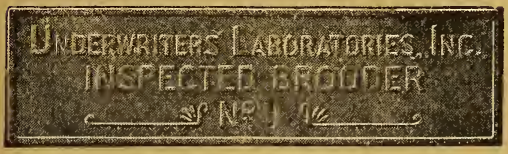

\section{DEMAND THIS LABER} YOUR SAFETY

Form of Brass Label to be found (in serial number) on every Oyphers Bruoder. All sizes.

It has often been said of Btandard Cyphers Inoubator that
This double use of the Cyphers Brooder means a constderablt saving of money. It makes a safo and comfortable enclosure for the young ohioks at night and saves the buying of a coop for them. These outdoor brooders, on account of their fire-proof construction, can be used indoors, although we supply a speotal brooder, Style D, for indoor purposes. - All Oyphers 1917 Brooders, both outdoor and indoor, contain either two or three apartments. The popular Btyle B (shown in illuetration herewith), contains three apartmentsfiret, roomy space under the hover; second, hover chamber; third, well-lighted exerolsing apartment.

THEY MOTHER THE CIICIKS ABTHER THAN A HEN.

An Important Reason for this is found in the great practioal advantage possessed by the entire line of Cyphers Brooders for 1917 in their self-regulating leature. For years the self-regu. lator was attached only to the highest priced Cyphers Brooder (Btyle C), but it was so well received that now it is attached to all Cyphers Company brooders. It automatically regulates the heat in the brooder underneath the hover at all times, whereas in brooders without a regulator the heat has to be governed by a continuous watching of the lamp and turning the wick up or down whenever more or less heat is required.

In addition to this unequaled line of broodors, we offor separately the Cyphers. Oo npany's world's challenge Adaptable Hover. This machinory-made, all-metal, guaranteod fire prool heating and brooding device is suitable to be used any where that heat is required for brooding ohicks or ducklings. It can be used in a roosting coop, colony house, shed, hen house, barn or other bullding with or without any adidional enolosure for the chicks, or in a large goods ease or organ or plano box.

Is pronounced by thousands of users to be the best device thus far invented for heating homemade brooders. Recommended especially for use In long brooding houses, one hover for each pen.

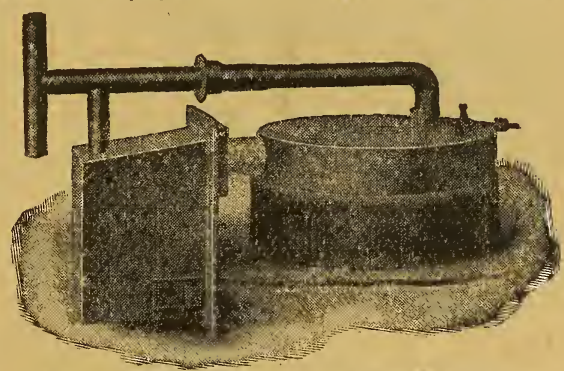

ALT MET A ADAPTARE HIOVIER.

(Belf-Regulating and Bears Insurance Label as Separato Devieo.)

Adaptable hover is complete in itself, bəars insurance label as a separate device, and is safe to use anywhere. Weight, boxed for shipment, only 40 pounds.

Sires and Prices of CJphers Adaptable Horer and Brooders.

Freo on Board Cars, Syracuse, N. Y.

Adaptable Hover, eapacity 75 ohioks,

810.00

Btyle A, Two Apas tment Outdoor brooder, oapacity 76 chicks, . . . . . . . . 16.60

Style B, Three Apartment Outdoor Brooder, capacity 100 chloks, _ . . . . . . . 19.50

Style D, Two Apartment Indoor Brooder, capaolty 76 ohioks, . . . . . . 14.60

Prices subject to change without notice. 


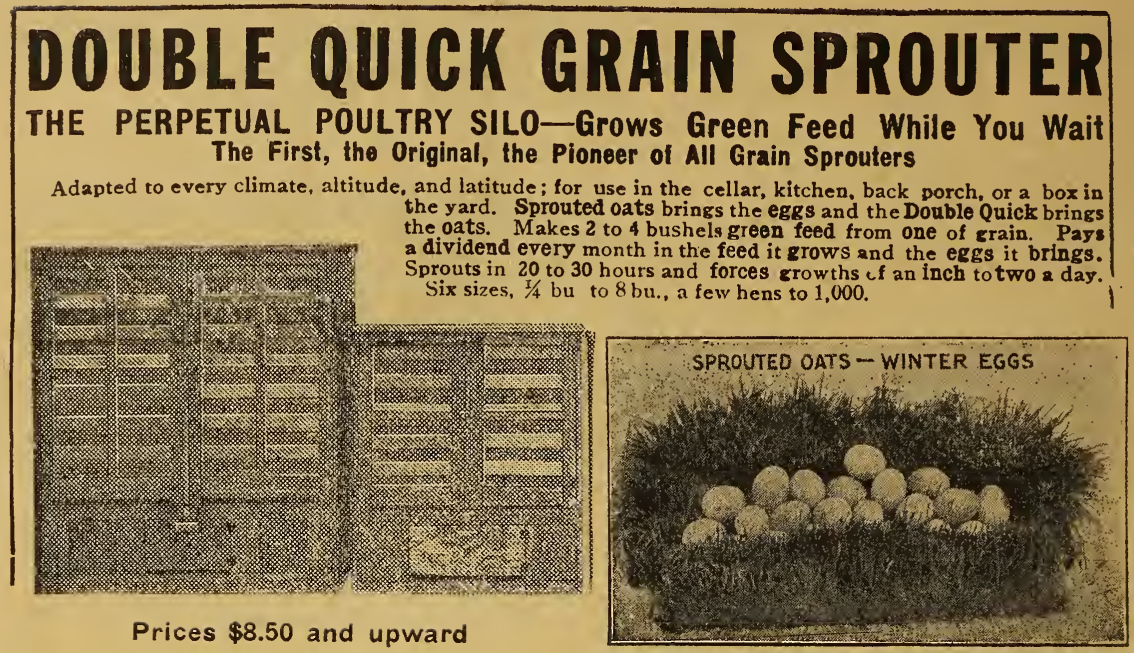

\section{CYCLE HATCHERS, BROODER--HATCHERS}

1 Oycle Hatcher, with thermometer,

$\$ 660 \mid 1$ Brooder Hatcher, with thermometer, $\$ 800$ 2 Oycle Hatchers,

1225 2 Brooder Hatohers. “

1675

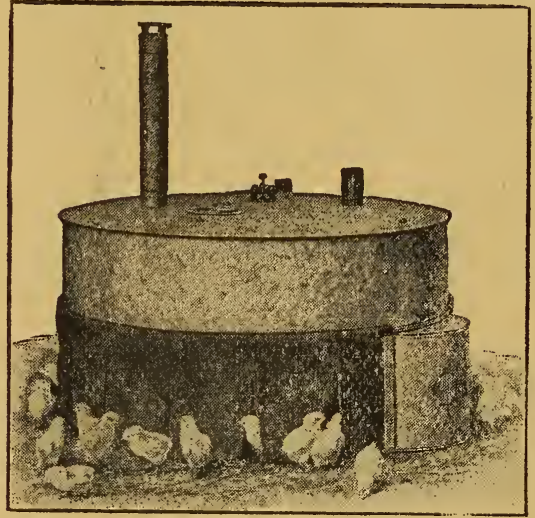

Shows the CyphersCompany PortableHover in Use on Floor of Poultry House. Chicks at all times are on a level with surrounding floor.

\section{CYPHERS PORTABLE HOVER}

Self Regulating. Indoor Use. \$Q.50

Tho self-re rulating and selforenth. ating Portable Fover, fllustrated herewith, wes invented hy Cyphers Incubator Company in 1910, and has been well tested during three saasons of practical use on the Cyphers Compeny Poultry Farm. It is the only Self-Ventllating portable brocding hover thus far invented and We cuaranteed it to be the best device or the marlret.

As its name Indicates, the Cyphers Portable Hover can be picked up at any time-hover. lump-box, lamp, regulating devlce, all complete -and moved to a new spot or any place the oper. ator may desire and the deviou will comtinue in operation right along. The lamp n ed not be removed at this time nor the wiok so much as turned down. Is very convenient for cleamings and for moving the chicks from one location to another.

This Hover has a rated capacity of seventy-ive newly batched chickb, or of flfty ohloks that are ten days to six weeks old. It will hover comfortably one hundred newly hatehed chicke.

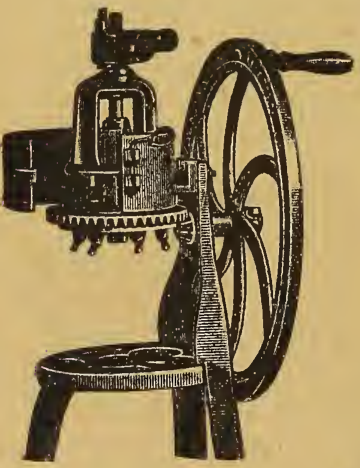

\section{MANN'S CELEBRATED BONE CUTTERS}

We offer the best Bone Mill on the market. Fully warranted against breakage for two years. The only machine that will cut green bone fine enough for Bantams and little chickens

Price List of Mann's Green Bone Cutters

No. 5 C with Crank Handle.................\$7.00

No. 5 B with Balance Wheel................ 9.00

No. 5 B M with Balance Wheel and Iron Stand...... 11.50

No. 7 with Balance Wheel and Iron Stand..... 13.50

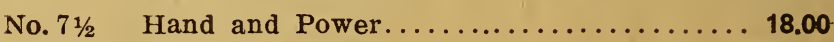

No. 9 Hand and Power........................

All Prices liable to change without notice. 
PRATTS Poultry Regulator and Remedies, Baby Chick Food, Animal Regulator and Remedies Satisfaction Guaranteed or Money Back

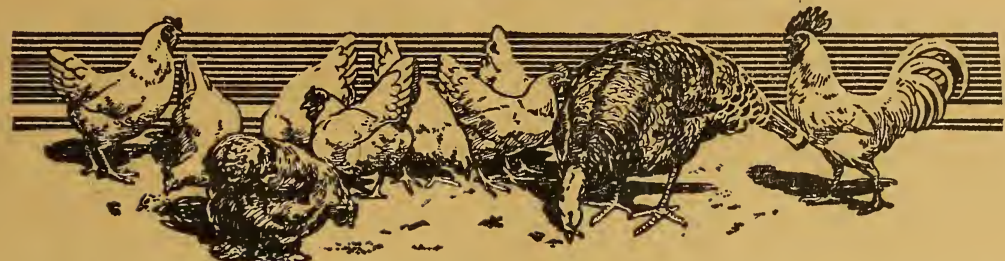

Healthy birds and lots of eggs, the two big things in poultry raising, are made certain by giving

\section{Pratts, Poultry Regulator}

$100-$ th. bags, $\$ 9.00 ; 25-$ lb. pail, $\$ 2.50 ; 12-1 b$. pail, $\$ 1.25$; pkgs., $50 \mathrm{c}$ and $25 \mathrm{c}$.

It builds up the vitality, insures sound digestion, sharpens appetite and prevents disease, thus putting birds in condition for heavy egg laying and winning blue ribbons.

Pratts is the original Poultry Regulator of America and is in use by the most successful poultry raisers everywhere.

When regularly used, hens lay throughout the year.

It will prevent chicken cholera, gapes, roup, rheumatism, expel worms, prevent leg weakness and egg eating. It will greatly improve turkeys, geese, ducks, pigeons and guineasinsuring quick growth and keep them free from disease.

Don't let ROUP cut your profits. The sure and easy "ounce of prevention" against this dangerously contagious disease is

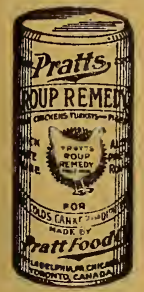

\section{Pratts \\ Roup Remedy}

Tablets or Powder, $\$ 1.00$, $50 \mathrm{c}, 25 \mathrm{c}$.

Quickly absorbed by the blood, purifies the system. reduces fever, allays inflam. mation. The safe remedy for roup, colds, catarrh and all had weather diseases.

Get rid of lice on your poultry, in nests, dust baths, incubators and elsewhere in a day's time by using

\section{Pratts Powdered Lice Killer} $40 \mathrm{c}$ and $25 \mathrm{c}$.

Effective, non-poisonous, non-irritating. May be used wherever a powder is suitible. A splendid deodorizer.

It quickly and thoroughly kills all lice on little chicks, big chicks, setting hens and incubator chicks. It rids horses, cattle, hogs, dogs, and cats of lice, and destroys ticks on sheep. It destroys insects and bugs on vines, plants and flowers. A valuable deodorizer and disinfect-

ant for all poultry houses, barns, stables and dwellings. Drives out moths from clorets, furniture, carpets and clothing.
When baby chicks come, keep them healthy and growing and bring even the weak ones along by feeding

\section{Pratts, Baby Chick Food}

$1.4 \mathrm{lbs}$. for $\$ 1.00$. Packages $50 \mathrm{c}$ and $25 \mathrm{c}$.

A largely predigested baby tood for baby chicks. Guaranteed to raise every livable chick. Costs cent a chick for three weeks. Prevents leg weakness, white diarrhoea, "pasting up" ant other chick diseases.

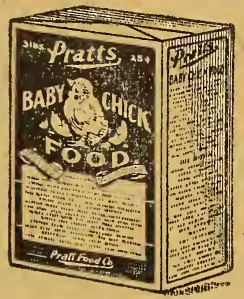

To protect your chicks from white diarrhoea, the most destructive of all chick diseases, it is only necessary to give

\section{Pratts.}

\section{White Diarrhoea Remedy}

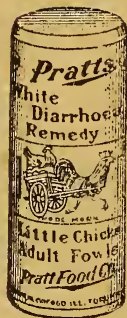

$50 \mathrm{c}$ and $25 \mathrm{c}$ in the drinking water from the first drink. This remedy has saved many dollars' worth of chicks for poultry raisers. You can depend on it.

If poultry keepers would regularly spray the chicken houses, roosts, dropping boards and utensils with

\section{Prafts Poultry Disinfectant}

only $\$ 1.00$ a gallon, most all their troubles would vanish. This great disinfectant is a real wonder-worker in the poultry yard.

Three times as powerful as crude carbolic acid. A sure deodorizer, germicide and liquid lice killer. Use it for roup, colds, and other contagious diseases.

We want you to notice the price, $\$ 1.00$ per gallon, making it the lowest priced disinfectant on the market. Others of equal strength are usually sold for $\$ 1.50$ per gallon. Half gallon, $60 \mathrm{c}$; quart, $35 \mathrm{c}$.

There is a Pratt Remedy for nearly every curable poultry disease. 


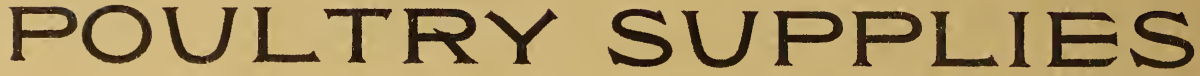

Beef Scraps.....tb. $31 / 2 \mathrm{c} ; 100$ IDs. $\$ 3.50$ Fountains, Drinking, galv. iron, Crushed Shell...1b. 1c; $100 \mathrm{tbs} .60$ small, 20c; medium, 25c; large, Bone Meal, raw.1b. 3c; 100 Ios. 2.75 Alfalfa, Mealed ib. $3 \mathrm{c}$; $100 \mathrm{tbs}$. 2.00 Bowker's Animal Meal, 10 Itss.

$35 \mathrm{c} ; 25$ tbs. $75 \mathrm{c} ; 50 \mathrm{Hbs}$. $\$ 1.50$;

100 tbs.

100 .................. 2.75 Bands, Dble. Clinch.doz. 15c; $100 \quad .65$ Bands, Adjustable..doz. 15c; $100 \quad .65$ Bands, Pigeon Leg.doz. 15e; 100.65 Clover Cutter, without stand... 8.50 Boxes for grit and shell....... 18.50 Caponizing Instruments (post-

paid) ............\$2.50, \$3.00, 4.00

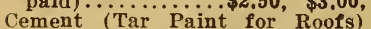

Cement (Tar Paint for Roofs) 1.25 Coop, New irodel Brood........ 3.50 Charcoal, Nodi, 3 sizes, fine, me-

dium, coarse, 2-1b. carton 10c;

50 - Ib. sack................ 1.00 Corn Shellers (Iron King) ....... 1.00 Candle, Sulphur Fumigating.... .15

Cyphers Foods.......At Market Prices Chick

Forcing

s'eratching

Teveloping

Laying Mash

Banner Root Cutter, No. ‘.... 5.00

Fancier's Root Cutter.......... 1.00

lioot Cutter, Pulley and Crank.

No. $26 \ldots \ldots \ldots \ldots \ldots \ldots \ldots \ldots . \ldots \ldots$

Root Cutter (crank only) ..... 9.00

ligg Cartons (Paper), 12-egg,

Humpty Dumpty Egg Cases, f; doz. size, $30 \mathrm{c} ; 12 \mathrm{doz}$. size.

ligg, Porcelain Nest, doz.

Niggs, Medicated, doz.

Dry Mash or Chicken Chowier

Food H.........tb. 3c; 100 tbs. 2.50

cood Hoppers, Dry-

Boston and Favorite.

Cyphers and Sexton.

Fountains, Wall, 1 ga. $50 \mathrm{c} ; 2$ ga. 75

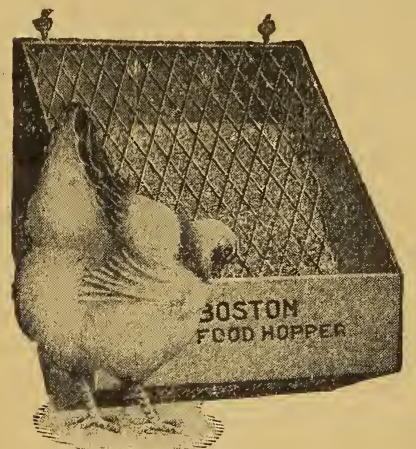

Fountain, Warm Water Drinking 1.50

Fencing, Hexagon-2-inch mesh, made $12,18,24,36,48,60$ and 72 inches wide; 1 -inch mesh, made $12,18,24,36,48$, 60 and 72 inches wide, each roll contains 150 lineal feet .....................

American Poultry Fence, a fence, not a netting-2158, per rod, 45c; 1558 per rod............ Grit, Crystal Granite, 3 sizes, $\ldots \ldots \ldots \ldots \ldots$. D. 2c; $100 \mathrm{~ms}$. Grit, Foust Health $3 \ldots \ldots \ldots$ Gun, Jumbo Powder........... 2.00 Grains-Corn Cracked, Canada Peas, Wheat, Buckwheat, Millet.

....................... Market Prices Heneta................... Knives, Poultry Killing, each.. .50 Markers, Phila. Poultry, each.. .25 Mill, Tennessee Grinding...... 2.00 Extra Grinders for same, each

Iill, Oriole Farm and Grist, No.

21 , 25.00 Irill, Balance Wheel Grist...... 2.25 Moisture Device, Automatic.... 1.50 cee's Lice Killer. 1 qt.35c; 2 qts. $60 \mathrm{c} ; 4$ qts. 1.00 Nests Earthen Pigeon, i5c; $\mathrm{dz}, 1,75$ Phíladelphia Poultry Marker... 25 Poutrelphia Poultry Marker... .25 35 Poultry Foods-

Pratt's, pkg........25c and .50 Lee's Egg Maker, pkg.25c and 2.00 Powder, Lambert's Lice, $5 \mathrm{oz}$. $10 \mathrm{c} ; 15$ oz. $25 \mathrm{c} ; 48$ oz. $50 \mathrm{c}$; $100 \mathrm{oz}$.

Remedies, Cyphers Poultry .... Remedies, Roup Cure, Conkey's..25c, $50 \mathrm{c}, \quad \mathbf{1 . 0 0}$
Roup Cure, Rust's........25c, .50 absolutely rat-proof.
Roofing, Durable, 2 ply, per square, $\$ 2.00 ; 3$ ply, per sq., 2.25 Each roll contains 1 or 2 squares.

Roofing Caps, tin, per 10....... 10

Roofing Nails, per to......... .05 Shells, Oyster, 100 Ibs........... .60 Special price for larger lots.

Spray Pumps,for spraying white-

wash $\ldots \ldots \ldots \ldots \ldots \ldots 3.00$ and 4.50 Sprayers, Compressed Air, galv.

iron .............\$2.50 to 7.75 Sprayers .............250 to 1.00 Staples, Fence, per to ......... .05 Staples, Fence, per ib.......... . . 10 Staples, Poultry Fence, per 10.. 1.10 Salt Cat........ brick 10c; doz. 1.00 Add $20 \mathrm{c}$ extra for postage.

Thermometers, Incubator $\ldots \ldots . \quad .60$ Thermometers, Brooder.35c and .50

Testers, X-Ray Egg.......... .25

Trays, Pedigree Hgo, per pair

\section{BIRD SEED AND SUPPLIES}

Canary, Hemp, Rape, Millet,

Maw, Unhulled Rice.Market Prices Sumflower Seed...to. 10c; 3 tos. $\$ .25$ Shepard Song Restorer, bottle.. .25 Iarshall's Song Restorer, bottle .25 Iocking Bird Song Restorer, bot .30 Bird Gravel.......pk. 10c; 3 for...25

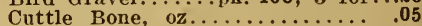
Pepper Seed, oz............... Lettuce Seed, oz...............

\section{PIGEON \& DOVE SUPPLIES}

Canada Peas, Choice Wheat, Yellow Corn, small kernels, Kaffir Corn, Millet, Hemp...

.................... Market Prices Dog Biscuit........ 1b. $10 \mathrm{c} ; 3$ tbs. .25 og Biscuit........ 10. $10 \mathrm{c} ; 3 \mathrm{mbs}$. old Grist Mill, Milk-Bone in Old Grist Mill, Milk-Bone in
bulk...........tb. 10c; pkg. .25

\section{BOSTON DRY FOOD HOPPER}

\section{The Food-Saving, Rat-Proof Hopper That}

Made Dry-Feeding of Poultry a Success.

The use of these hoppers will positively save their original cost every week in the case of adult fowls and every month or less in the case of chicks. Besides this they will help greatly to keep your fowls and chicks in a healthy condition by insuring them clean food entirely free from filth of any kind. Every poultryman will appreciate this feature.

Prices: Large Hopper for Dry Feed, holds $1 / 2$ bu., each......\$1.25

Small Hopper for Beef Scrap, Grit, etc., holds 1 peck. 1.00

Long Chicken size, holds 1 peck.................... 1.50

Short Chicken size, holds $1 / 2$ peck....................... 1.10

Hopper is locked for the night by a hook in lower end, making it

\section{RAT EDRN}

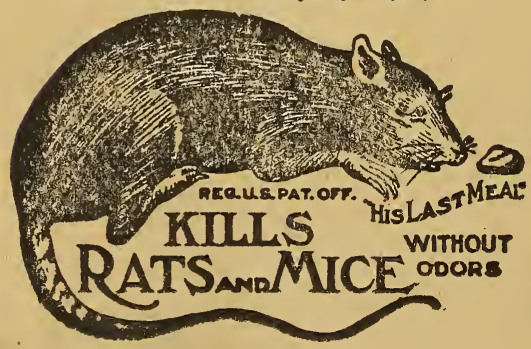

Will Exterminate Rats and Mice from your premises in a safe, sane and sanitary manner.

NO ODORS OR SMELLS. It mummifies them. No matter where they die they simply DRY UP. Positively do not smell. Rat Corn is a new and scientific discovery, and without a doubt the greatest rat destroyer in the world; the only one that kills rats without any bad, dangerous or disagreeable effects. A trial will convince you. 25c, 50c and $\$ 1.00$ per can; 6. th. pail $\$ 5.00$ express prepaid.

\section{Red Wing Insect Powder}

In the New Bellows. Insect Powder and Bellows combined ALL FOR TEN CENTS

RED WING is the Best Insect Powder that can be proured and once you try it you will use no other. For the destruction of Roaches, Bed-Bugs, Fleas, Moths; Ants, Flies, etc. 
37 Cobaea 39 Geranium 41 Matricaria

Coccinea Indica 39 Globe Amarauth 41 Maurandia

38 Coleus 39 Gloxinia

38 Conrolrulus $\quad 39$ Godetia

38 Corcopsis $\quad 39$ Gourds

38 Cosmos

38 Cucurbit

38 Cyclanien

38 Cyperus

39 Grassen

7 Baptisia

37 Begonias

37 Bellis

Brachycome

37 Calceolaria

37 Calendula

37 Calliopsis

37 Campanula

37 Canary Bird

$37 \quad$ Vine

37 Candy Tuft

37 Canna

7 Canterbury Bell 39 Echinocyst

37 Carnation

37 Castor Oil Bean

37 Celosia or Cris tata

37 Centaurea

Chrysanthe-

37 mums

Cineraria

7 Clianthus
38 Delphinium

38 Dianthus

Didiscus

38 Digitalis

38 Dolichos

39 Dracaena

9 English Daisy

9 Erigeron

Eryngium

39 Eschscholtzia

39 Euphorbia

Forget-me-not

39 Four O'Clock

39 Fox Glove

39 Fuclısia

39 Gaillardia
Gypsophila

40 llelichrysun

40 IIeliotrope

40 Hibiscus

40 Hollyhocks

40 Honesty

40 Ifumulus

40 Impatiens

40 Ipomoea

40 Job's Tears

40 licnilworth Ivy

40 Lantana

40 Larksprus

40 La thyrus

40 Larender

40 Linaria

41 Linum

41 lobelia

41 Lophospermum

41 Lupinus

41 Lychnis

41 Marigold
41 Iesembryan

41 themum

41 Mignonette

41 IIimosa

41 Mimulus

41 Miribilis

41 Momordica

41 Morning Glory

41 Musa Ensete

41 Musk Plant

41 Myosotis

41 Nasturtiums

41 Nicotiana

41 Nigella

41 Orna. Grasses

41 Pansies

41 Passiflora

41 Pentstemol

41 Perilla

41 Petunia

41 Phlox Drum-

41 mondi

41 Pinks

41 Poppies

41 Portulaca

41 Primula

41 Pyrethrum
42 Reseda

2 Rhodanthe

Ricinus

42 Salpiglossis

42 Salvia

42 Scabiosa

2 Scarlet Runner

42 Sclizanthus

42 Smilax

42 Snapdragon

42 Solanum

42 Stocks

42 Sunflower

42 Sweet Peas

42 Sweet Rocket

42 Sweet William

42 Tagetes

42 Thunbergia

43 Torenia

43 Tritoma

43 Tropaeolum

43 Verbenas

viola

43 Vinca

43 Wall Flower

4 Wild Cueumber 4

43 Wild Flower

43 Zinnias
43 Garden

43
43
43
43
43
43
43
43
43
43
43
43
44
44
44
44
44
44
44
44
44
44
44
44
44
44
44
44

INDEX TO VEGETABLES, GRAINS, GRASSES, PLANTS, BULBS, ROOTS, ETC.
Nam

Isparagu

Barley

Beans

Beardless BarleJ

Beets

Broccoli

Brussels Spouts

Buckwheat

Bulbs

Cabbage

Carrots

Cauliflower

Celery

Chervil

Celeriac
Page Name

ts 5 Chicory

11 Clover Seed

Corn 2, 3 ,

16, 17 Corn Salad

9 Dodder, To

8, 19 Egg Plant

19 Endive

19 Eureka Ensilage

3 Corn

46 Field Corn

20 Field Seed

21 Grass Seed

22 Hairy Vetcl

22 Herbs

24 Ideal Sugar Mangel

23 Beets
Page Name I'age Name

23 Improved Leaming Oats

14 Corn 6 Okra

Okra

6 Parsley

24 silage Corı

25 Kale

Lawn Grass Seed

Lawn Supplies

Leek

10 Lettuce

6 Lucie's Favorite

13, 14 Dent Field Corn

$1,13,14$ Mangel Beets

12 Mushroom Spawn

35 Muskmelon

Mustard

7 Nasturtium
25 Parsnips

25 Peas

1 Pepper

1 Plants, lioots

25 Potatoes

26 Pride of

6 Pumpkin

19 Radish

27 Rhubarb

27 Roots

27 Russet Potato

28 Rye
Page Name

5 Sage

28 Salsify

28, 29 Soy Beans

29 Special Grasses' 13,1

29 Spinach

$3,30,31$ Spring Plants

33,34

31,32 Squash

46 Strawberry Plants 46

15,32 Sweet Corn

Sweet Herbs

6 Swiss Chard

32 Timothy

2, 33 Tobacco

33 Tomatoes

3, 46 Turnips

15 Watermelon

13 Winter Vetch

18,34

INDEX TO IMPLEMENTS, FERTILIZERS, MISCELLANEOUS SUPPLIES, ETC.

Adjustable Weeder 69 Double Wheel Hoe 48 Hatchers

\section{Aerato}

Bargain

Barrows

Berry Baskets

Bird Seed

Bordo Mixture

Bottle Filler

Brooders

Calf Meal

Carborundum Scyth Stones

Carriers, Hay, Ensi-

lagc, Manure

Feed, Litter

Florists'

48

67 Elevator Potato

83 Digger

46 Exterminators

88 Fanning Mill

15 Farm Gates

60 Farmers' Drill

86 Farm Wagons

Hay Caps

Hay Carrie

77 Hay Cars

55 Hay Loader

78 Haying Tools

71 Hoeing Machine

73 Hoes

, 61 Fencing S0, 81, 82 Hog Ringer's $72 \begin{gathered}\text { Fertilizer Distribu- } \\ \text { tors }\end{gathered} 51$ Horse Hoe Hotbed Drill

0, 81, 82 Hovers

Florists' Sundries 46 Incubators

14 Insecticides

46 Iron Age Tool

84, 86 Posts

70 Potato Digger

81, 82 Stable Fixtures

72 Potato Planters

77

51 Stalls 
